VILNIAUS GEDIMINO TECHNIKOS UNIVERSITETAS

Violeta VOIŠNIENÉ

\title{
STATYBINĖS KERAMIKOS SU LAKIAISIAIS IR DUGNO PELENAIS STRUKTŪROS IR SAVYBIŲ TYRIMAI
}

DAKTARO DISERTACIJA

TECHNOLOGIJOS MOKSLAI, MEDŽIAGŲ INŽINERIJA (T 008)

Vilnius, 2021 
Disertacija rengta 2017-2021 metais Vilniaus Gedimino technikos universitete.

\section{Vadovas}

dr. Olga KIZINIEVIČ (Vilniaus Gedimino technikos universitetas, medžiagu inžinerija - T 008).

Vilniaus Gedimino technikos universiteto Medžiagų inžinerijos mokslo krypties disertacijos gynimo taryba:

\section{Pirmininkas}

dr. Valentin ANTONOVIČ (Vilniaus Gedimino technikos universitetas, medžiagų inžinerija - T 008).

\section{Nariai:}

prof. habil. dr. Aivaras KAREIVA (Vilniaus universitetas, chemija - N 003), doc. dr. Ritoldas ŠUKYS (Vilniaus Gedimino technikos universitetas, medžiagų inžinerija - T 008),

dr. Jaunius URBONAVIČIUS (Vilniaus Gedimino technikos universitetas, medžiagų inžinerija - T 008),

doc. dr. Jiri ZACH (Brno technologijos universitetas, Čekija, statybos inžinerija - T 002).

Disertacija bus ginama viešame Medžiagų inžinerijos mokslo krypties disertacijos gynimo tarybos posėdyje 2021 m. spalio 7 d. 10 val. Vilniaus Gedimino technikos universiteto senato posèdžių salëje.

Adresas: Sauletekio al. 11, LT-10223 Vilnius, Lietuva.

Tel.: (8 5) 274 4956; faksas (8 5) 270 0112; el. paštas doktor@vilniustech.lt

Pranešimai apie numatomą ginti disertaciją išsiųsti $2021 \mathrm{~m}$. rugsejo $6 \mathrm{~d}$.

Disertaciją galima peržiūrèti Vilniaus Gedimino technikos universiteto talpykloje http://dspace.vgtu.lt ir Vilniaus Gedimino technikos universiteto bibliotekoje (Saulètekio al. 14, LT-10223 Vilnius, Lietuva).

Vilniaus Gedimino technikos universiteto 2021-040-M mokslo literatūros knyga doi: 10.20334/2021-040-M

(C) Vilniaus Gedimino technikos universitetas, 2021

(C) Violeta Voišnienè, 2021

violeta.voisniene@vilniustech.lt 
VILNIUS GEDIMINAS TECHNICAL UNIVERSITY

Violeta VOIŠNIENÉ

\section{INVESTIGATION OF STRUCTURE AND PROPERTIES OF BUILDING CERAMICS WITH FLY AND BOTTOM ASH}

DOCTORAL DISSERTATION

TECHNOLOGICAL SCIENCES,

MATERIALS ENGINEERING (T 008)

Vilnius, 2021 
Doctoral dissertation was prepared at Vilnius Gediminas Technical University in 2017-2021.

\section{Supervisor}

Dr Olga KIZINIEVIČ (Vilnius Gediminas Technical University, Materials Engineering - T 008).

The Dissertation Defence Council of Scientific Field of Materials Engineering of Vilnius Gediminas Technical University:

\section{Chairman}

Dr Valentin ANTONOVIČ (Vilnius Gediminas Technical University, Materials Engineering - T 008).

\section{Members:}

Prof. Dr Habil. Aivaras KAREIVA (Vilnius University, Chemistry - N 003), Assoc. Prof. Dr Ritoldas ŠUKYS (Vilnius Gediminas Technical University, Materials Engineering - T 008),

Dr Jaunius URBONAVIČIUS (Vilnius Gediminas Technical University, Materials Engineering - T 008),

Assoc. Prof. Dr Jiri ZACH (Brno University of Technology, Czech Republic, Civil Engineering - T 002).

The dissertation will be defended at the public meeting of the Dissertation Defence Council of Materials Engineering in the Senate Hall of Vilnius Gediminas Technical University at 10 a. m. on 7 October 2021.

Address: Sauletekio al. 11, LT-10223 Vilnius, Lithuania.

Tel.: +370 5274 4956; fax +370 5270 0112; e-mail: doktor@vilniustech.lt

A notification on the intend defending of the dissertation was send on 6 September 2021.

A copy of the doctoral dissertation is available for review at Vilnius Gediminas Technical University repository http://dspace.vgtu.lt and at the Library of Vilnius Gediminas Technical University (Sauletekio al. 14, LT-10223 Vilnius, Lithuania). 


\section{Reziumè}

Disertacijoje nagrinejjamos po komunalinių atliekų deginimo susidariusių lakiųu ir dugno pelenų naudojimo, kaip priedų statybinejje keramikoje, galimybės. Norint ịvertinti lakiujų ir dugno pelenų poveikị keraminès šukès struktūrai ir savybėms, parinkti technologinius parametrus, atsižvelgiant $i$ žaliavų ir minètų priedų cheminę, mineraloginę sudètį, savybes, tiriamos keraminių šukių fizikinės ir mechaninès savybės, ilgaamžiškumas, toksiškumas. Po komunalinių atliekų deginimo susidariusių lakiụjų ir dugno pelenų naudojimas statybinès keramikos gamyboje leistų sumažinti minètų atliekų kiekị ir teigiamai veiktų ekologinị balansą.

Disertaciją sudaro ịvadas, trys skyriai, bendrosios išvados, rekomendacijos, naudotos literatūros ir autorès publikacijų disertacijos tema sąrašai. İvade aptariama tiriamoji problema, darbo aktualumas, aprašomas tyrimų objektas, formuluojamas darbo tikslas bei uždaviniai, aprašoma tyrimų metodika, iškeliamas darbo mokslinis naujumas, darbo rezultatų praktinè reikšmè bei ginamieji teiginiai. Ivado pabaigoje pateikiamos autorès publikacijos disertacijos tema, pranešimai konferencijose bei disertacijos struktūra. Pirmajame skyriuje pateikiama literatūros analizè apie po komunalinių atliekų deginimo susidariusių lakiųjų ir dugno pelenų sudèti, savybes, apdorojimo technologijas bei naudojimo galimybes gaminant keraminius gaminius. Skyriaus pabaigoje suformuluotos išvados ir tikslinami disertacijos uždaviniai. Antrajame skyriuje aprašytos darbe naudojamos pagrindinès žaliavos ir priedai, pateikti keraminių šukių gamybos technologiniai parametrai bei tyrimams naudotos metodikos. Trečiajame skyriuje pateikti lakiujų ir dugno pelenų cheminès, mineraloginès, granuliometrinès sudèties, fizikinių savybių bei mikrostruktūros tyrimai. Nustatyta lakiųjų ir dugno pelenų įtaka keraminès šukès mineraloginei sudéčiai, struktūrai, fizikinèms ir mechaninèms savybėms, ilgaamžiškumui, nagrinèjamas toksiškumas. Remiantis gautais tyrimų rezultatais skyriaus pabaigoje suformuluotos išvados ir pateikiamos rekomendacijos.

Disertacijos tema paskelbti septyni straipsniai: du - mokslo žurnaluose, ịtrauktuose ị Clarivate Analytics Web of Science leidinių sąrašą, turinčiuose citavimo indeksą, du - Clarivate Analytics Web of Science duomenų bazès „Conference Proceedings" leidiniuose, trys - kitụ tarptautinių duomenų bazių leidiniuose. Disertacijos tema perskaityti septyni pranešimai nacionalinėse ir tarptautinèse mokslinèse konferencijose. 


\section{Abstract}

The dissertation considers possibilities of using fly ash and bottom ash from municipal solid incineration waste in building ceramics. In order to evaluate the effect of the examined fly ash and bottom ash on the structure and properties of clay bricks, technological parameters were selected according to the chemical and mineralogical composition of raw materials and additives, their properties, physical-mechanical properties of clay bricks are investigated, durability, toxicity. Usage of fly ash and bottom ash from municipal incineration waste in the production of building ceramics would allow to reduce the amount of mentioned waste and positively affect ecological balance.

The dissertation consists of an introduction, three chapters, general conclusions, reference list and list of the author's publications on the topic of the thesis. The introductory chapter discusses about the research problem, relevance of the thesis, describes the object of research, formulates the aim and objectives of the thesis, describes the research methodology, raises the scientific novelty of the thesis, the practical value of the research findings and defended statements. At the end of the introductory chapter, the author's dissertation publications, conference reports and the structure of the dissertation are presented. The first chapter presents literature review on the composition, properties, treatment technologies and application possibilities of municipal solid incineration waste (fly ash and bottom ash) in the production of ceramic products. At the end of the chapter, conclusions are formulated and the tasks of the thesis are specified. The second chapter describes the main raw materials and additives used in the work, presents the technological parameters for the production of clay bricks, as well as the methods used for the research. The third chapter presents the research of chemical, mineralogical, granulometric composition, physical properties and microstructure of fly ash and bottom ash. The influence of fly ash and bottom ash on the mineralogical composition, structure, physical-mechanical properties, durability of the clay bricks was determined, and the toxicity is examined. Based on the obtained research results, conclusions were formulated at the end of the chapter and recommendations are provided.

7 articles have been published on the topic of the dissertation: two - in scientific journals included in the list of Clarivate Analytics Web of Science publications with citation index, two - in publications of Clarivate Analytics Web of Science database Conference Proceedings, three - in publications of other international databases. Seven reports on the topic of the dissertation have been presented at national and international scientific conferences. 


\section{Žymëjimai}

\section{Simboliai}

$\rho$ - tankis;

$D$ - sąlyginis porų ir kapiliarų sienelès storis;

$K_{i s}$ - porų ir kapiliarų įsotinimo koeficientas;

$R$ - koreliacijos koeficientas;

$R^{2}$ - determinacijos koeficientas;

$s_{e}-$ standartinis nuokrypis;

$W$ - vandens imirkis;

$W_{a}-$ atvirasis poringumas;

$W_{b}$ - bendrasis poringumas.

\section{Santrumpos}

BA - keraminès šukès su dugno pelenais žymuo;

$\mathrm{C}$ - keraminès šukès, pagamintos naudojant molị, žymuo;

CS - keraminès šukès, pagamintos naudojant molị ir smèlį, žymuo;

DP - dugno pelenai;

FA - keraminės šukės su lakiaisiais pelenais žymuo; 
FAW - keraminès šukès su vandeniu apdorotais lakiaisiais pelenais žymuo;

KDA - komunalinès deginimo atliekos;

LP - lakieji pelenai;

VLP - vandeniu apdoroti lakieji pelenai.

\section{Terminai ir apibrėžtys}

Dugno pelenai - degimo kameroje degimo proceso pabaigoje iškrentančios deginimo proceso atliekos (LR AM ịsakymas Nr. D1-805).

Eliuatas - tirpalas, turintis iš adsorbento išplautų medžiagų.

Formavimo mase - plastiškų (molis) ir neplastiškų (liesinantis ir kt. priedai) žaliavų komponentų vienalytis mišinys, naudojamas pusgaminiams formuoti.

Inertinè atlieka - tai atlieka, kurioje nevyksta jokie pastebimi fizikiniai, cheminiai ir biologiniai pokyčiai.

Keraminè šuke - bet kokios formos ir matmenų išdegta formavimo masè.

Lakieji pelenai - degimo kameroje degimo proceso pabaigoje filtruose surenkamos degimo proceso atliekos (Europos atliekų katalogas, kodas 1901 13).

Liesinantys priedai - formavimo mišinių komponentai, mažinantys formavimo masių plastiškumą ir/ar susitraukimus.

Molis - polimineralinè nuosèdinè uoliena, su vandeniu sudaranti plastinę masę, kuri džiūdama iggauna tam tikrą stiprumą, o po degimo sudaro keraminę šukę.

Plastiškas formavimas - reikalingas formos ir matmenų suteikimas $15-30 \%$ drègnio formavimo masei.

Pusgaminis - iš paruoštos formavimo masès bet kokios formos ir matmenų suformuotas gaminys.

Šlakas - deginimo proceso nedeganti liekana, susikaupusi degimo kameros dugne (LR AM įsakymas Nr. D1-805). 


\section{Turinys}

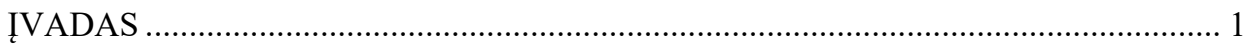

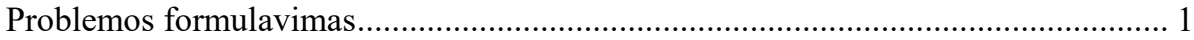

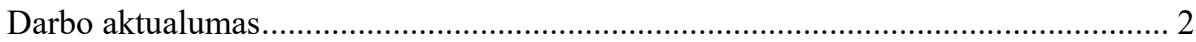

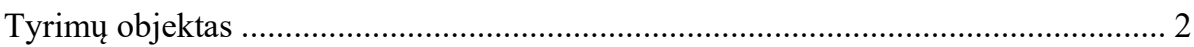

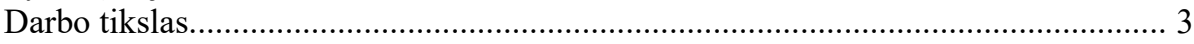

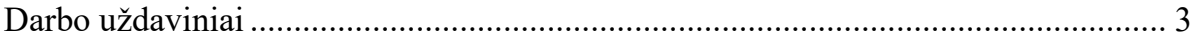

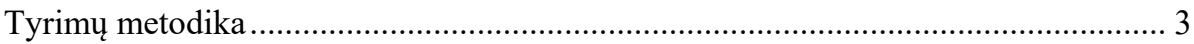

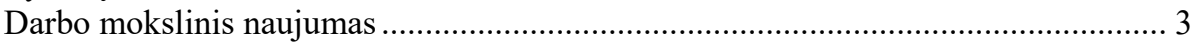

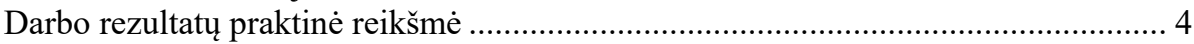

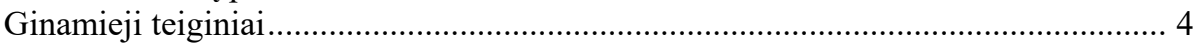

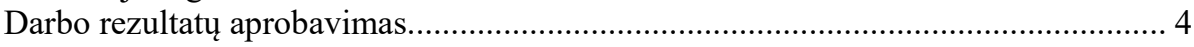

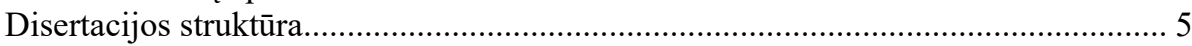

1. KOMUNALINIŨ DEGINIMO ATLIEKŲ LAKIŲJŲ IR DUGNO PELENŲ NAUDOJIMO STATYBINĖS KERAMIKOS GAMYBOJE MOKSLINIŲ

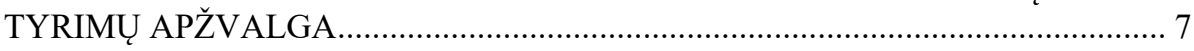

1.1. Dugno ir lakiujų pelenų ịvertinimas prieš naudojimą statybos pramonejje........... 9 1.1.1. Dugno ir lakiujų pelenų naudojimo aplinkosauginiai reikalavimai

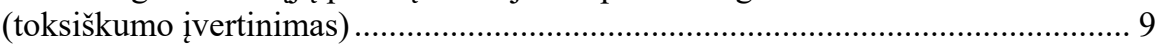

1.1.2. Dugno ir lakiųu pelenų sudètis ir struktūros įvertinimas............................. 13

1.2. Lakiujų ir dugno pelenų ịtaka statybinès keramikos savybèms ir struktūrai ...... 16

1.2.1. Dugno pelenų poveikis keraminių šukių mineraloginei sudèčiai, struktūrai ir savybèms ............................................................................... 17 
1.2.2. Lakiujjų pelenų poveikis degtų statybinių keraminių šukių struktūrai,

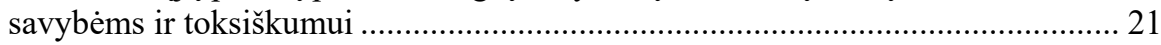

1.2.3. Dugno ir lakiujų pelenų paruošimo technologijos......................................... 24

1.3. Pirmojo skyriaus išvados ir disertacijos uždavinių formulavimas....................... 27

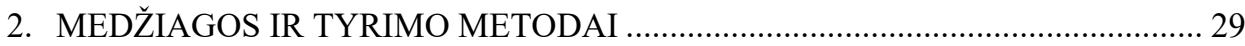

2.1. Tyrimams naudotos medžiagos ir jų charakteristikos ........................................ 29

2.2. Formavimo masių sudètys ir technologiniai parametrai..................................... 33

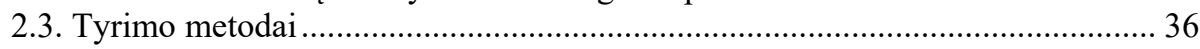

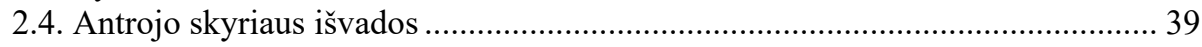

3. KOMUNALINIŲ DEGINIMO ATLIEKŲ LAKIŲJŲ PELENŲ, DUGNO PELENŲ BEI KERAMINIŲ ŠUKIŲ STRUKTŪROS,

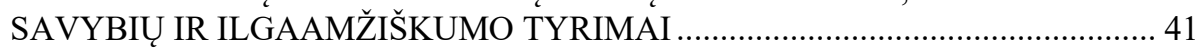

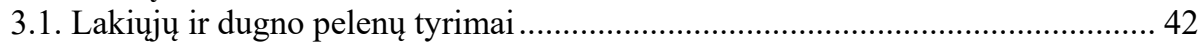

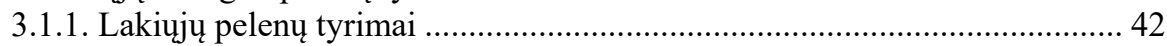

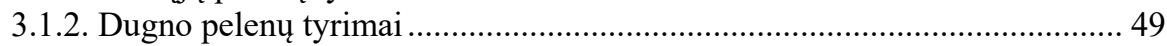

3.2. Keraminių šukių su lakiaisiais pelenais tyrimai ................................................ 52

3.2.1. Lakiujų pelenų ịtaka keraminių šukių mineraloginei sudèčiai ..................... 52

3.2.2. Lakiujų pelenų įtaka estetinei keraminių šukių kokybei................................ 56

3.2.3 Keraminių šukių su lakiaisiais pelenais termografiniai tyrimai..................... 57

3.2.4. Keraminių šukių su lakiaisiais pelenais toksiškumo ịvertinimas................... 61

3.2.5. Lakiujų pelenų ịtaka keraminių šukių savybèms ir struktūrai ...................... 66

3.2.6. Lakiujų pelenų ịtaka keraminių šukių mikrostruktūrai .................................. 71

3.2.7. Keraminių šukių su lakiaisiais pelenais ilgaamžiškumo tyrimai .................. 75

3.3. Keraminių šukių su dugno pelenais tyrimai ...................................................... 78

3.3.1. Keraminių šukių su dugno pelenais mineraloginès sudèties tyrimai ............ 78

3.3.2. Keraminių šukių su dugno pelenais termografiniai tyrimai.......................... 80

3.3.3. Sunkiujų metalų, chloridų ir sulfatų išsiplovimo iš keraminių

šukiu su dugno pelenais ir radioaktyvumo tyrimai............................................... 82

3.3.4. Keraminių šukių su dugno pelenais mikrostruktūros tyrimai ......................... 85

3.3.5. Dugno pelenų ịtaka keraminių šukių fizikinèms ir mechaninèms

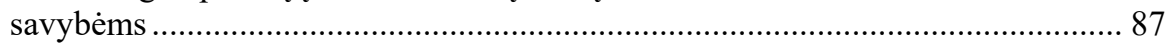

3.3.6. Keraminių šukių su dugno pelenais ilgaamžiškumas .................................. 90

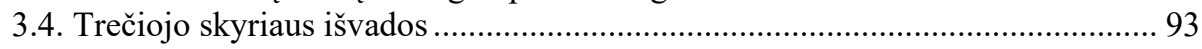

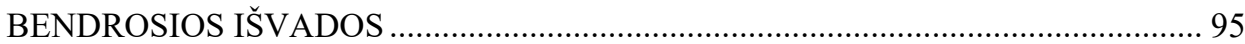

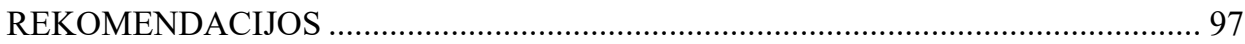

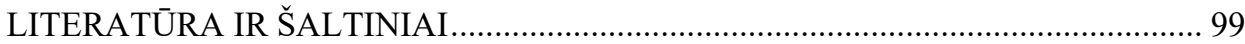

AUTORĖS MOKSLINIŲ PUBLIKACIJŲ DISERTACIJOS TEMA SĄRAŠAS....... 113

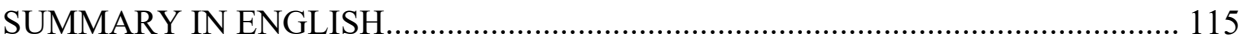




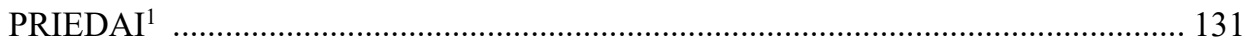

A priedas. Autorès sąžiningumo deklaracija .............................................................. 133

B priedas. Autorès mokslinių publikacijų disertacijos tema kopijos........................ 134

${ }^{1}$ Priedai pateikiami pridètoje kompaktinèje plokštelëje. 



\section{Contents}

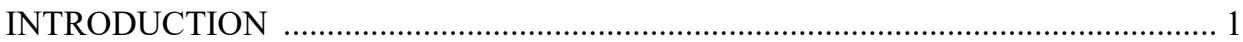

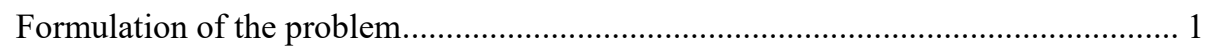

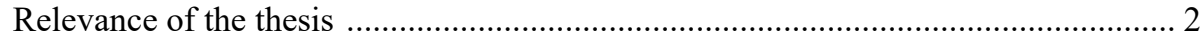

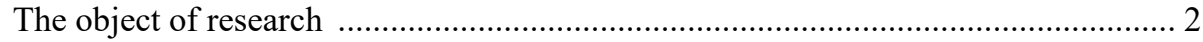

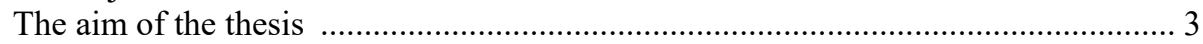

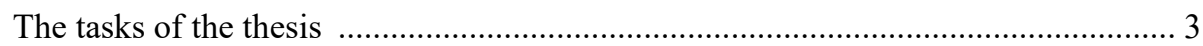

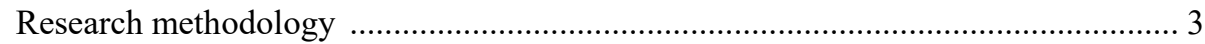

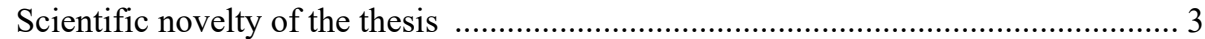

Practical value of the research findings ................................................................... 4

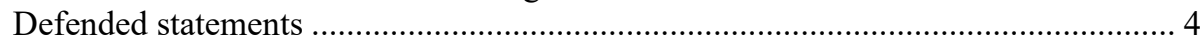

Approval of the research findings ..................................................................... 4

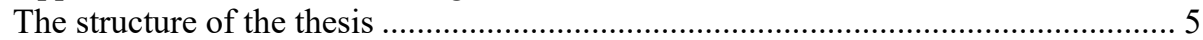

1. LITERATURE REVIEW ON THE USAGE OF FLY ASH AND BOTTOM ASH FROM MUNICIPAL SOLID WASTE INCINERATION IN THE PRODUCTION

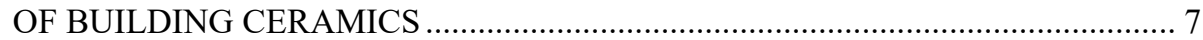

1.1. Evaluation of municipal solid waste incineration fly ash and bottom ash before usage in the construction indusry ............................................................ 9

1.1.1. Environmental requirements for the use of municipal solid waste incineration fly ash and bottom ash (toxicity assessment) ...................................... 9

1.1.2. Composition and structure assessment of municipal solid waste incinerationbottom and fly ash .............................................................................. 13 
1.2. Influence of municipal solid waste incineration bottom and fly ash on the properties and structure of building ceramics..................................... 16

1.2.1. Effect of municipal solid waste incineration bottom ash on mineralogical composition, structure and properties of building ceramics

1.2.2. Effects of municipal solid waste incineration fly ash on the structure, properties and toxicity of fired building ceramics ....................................... 21

1.2.3. Municipal solid waste incineration bottom ash and fly ash preparation technologies

1.3. Conclusions of the first chapter and formulation of the objectives

of the thesis

2. MATERIALS AND RESEARCH METHODS .................................................... 29

2.1.Materials used for the research and their characteristics ................................... 29

2.2. Compositions and technological parameters of formation masses .................... 33

2.3. Research methods..................................................................................... 36

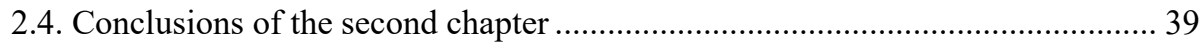

3. RESEARCH OF MUNICIPAL SOLID WASTE INCINERATION FLY ASH, BOTTOM ASH AND OF STRUCTURE, PROPERTIES AND DURABILITY OF CLAY BRIKS

3.1. Research of municipal solid waste incineration fly ash and bottom ash ........... 42

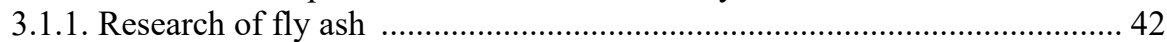

3.1.2. Research of bottom ash .................................................................... 49

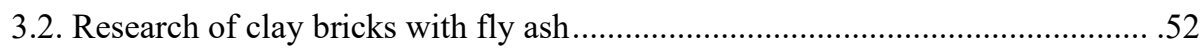

3.2.1. The influence of fly ash on the mineralogical composition of clay bricks .. 52

3.2.2. The influence of fly ash on the aesthetic quality of clay bricks................... 56

3.2.3. Research of Differential thermal analysis of clay bricks ........................... 57

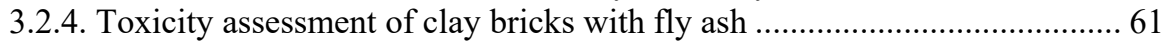

3.2.5. The influence of fly ash on the properties and structure of clay bricks ...... 66

3.2.6. The influence fly ash on the microstructure of of clay bricks .................... 71

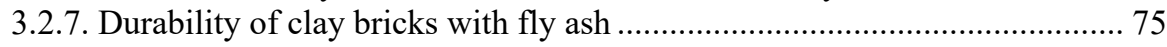

3.3. Research of clay bricks with bottom ash .................................................. 78

3.3.1. Research of of clay bricks with bottom ash mineralogical composition ..... 78

3.3.2. Research of Differential thermal analysis of clay bricks .......................... 80

3.3.3. Research of leaching of heavy metals, chlorides and sulphates

from of clay bricks with bottom ash, radioactivity studies................................ 82

3.3.4. Microstructure research of clay bricks with bottom ash ............................ 85

3.3.5. The influence of bottom ash on physical and mechanical properties

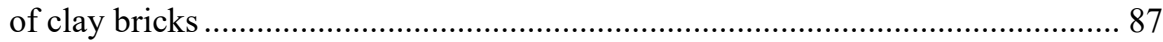

3.3.6. Durability research of clay bricks with bottom ash ................................. 90

3.4. Conclusions of the third chapter............................................................... 93

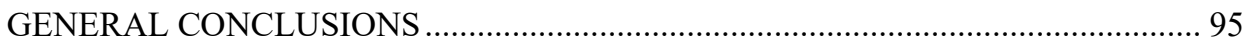

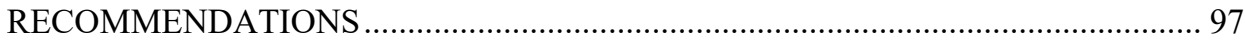


THE LIST OF SCIENTIFIC PUBLICATIONS BY THE AUTHOR

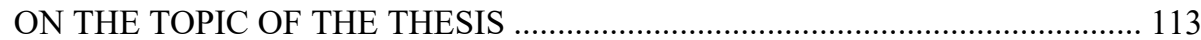

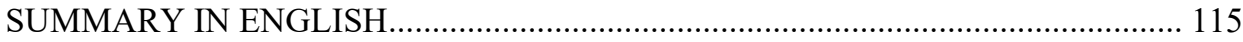

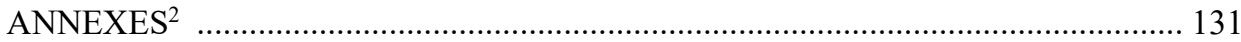

Annex A. Author's declaration of academic integrity.......................................... 133

Annex B. Copies of the scientific publications by the author on the topic

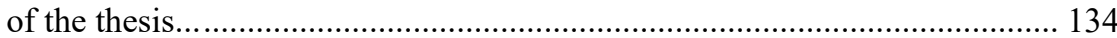

${ }^{2}$ The annexes are supplied in the attached compact disc. 



\section{Ivadas}

\section{Problemos formulavimas}

Augant ekonomikai komunalinių atliekų kiekiai nuolat didejja, o tokių atliekų deginimas šiuo metu laikomas pažangiausia komunalinių atliekų utilizavimo technologija, pasižyminčia mažiausiu poveikiu aplinkai. Todèl pasaulyje yra labai didelis po komunalinių atliekų deginimo susidariusių lakiujų ir dugno pelenų antrinio naudojimo poreikis. Pastarajį dešimtmetị daugelyje pasaulio šalių tokie lakieji ir dugno pelenai dažnai naudojami ịvairių statybinių medžiagų pramonèje. Norint išspręsti lakiujų ir dugno pelenų naudojimo statybinès keramikos gamyboje galimybes, būtina ištirti jų sudètis bei savybes, tinkamai atsižvelgiant ị naudojamas žaliavas, parinkti technologinius parametrus, įvertinti poveikị keraminių šukių savybėms ir struktūrai. Tačiau, pritaikius minètus priedus, matomas neigiamas poveikis keraminių šukių savybėms, o sunkiujų metalų, chloridų, sulfatų išsiplovimas iš keraminių šukių dažnai viršija normines ribas. Dèl to, gaminat keraminius gaminius su minètais priedais, dažniausiai koreguojami technologiniai gamybos parametrai, t. y. keliama degimo temperatūra, išlaikymo aukščiausioje degimo temperatūroje laikas, tai yra energetiškai neefektyvu, brangu, o naudojant lengvai lydžius molius, kartais neįmanoma. Todèl keraminių gaminių kūrimo galimybių poreikis, naudojant lengvai lydžius molius ir lakiuosius ar dugno pelenus, 
neaukštoje $1000{ }^{\circ} \mathrm{C}$ degimo temperatūroje, yra akivaizdus, norint prisidèti prie šalies ir regiono ekologinio balanso, efektyviai mažinant tokių atliekų kiekius ir taupant iškastines žaliavas.

\section{Darbo aktualumas}

Komunalinès atliekos pagal atsinaujinančių energijos šaltinių direktyvą 2009/28/EB yra pripažistamos kaip atsinaujinantis energijos šaltinis. Atliekų deginimas išgaunant šilumos ir/ar elektros energiją Europoje laikomas tinkamu atliekų tvarkymu. Visoje Europoje veikia apie 500 kogeneracinių jègainių, kuriose deginamos mišriosios komunalinès atliekos. Lietuvoje šiuo metu veikia trys komunalinių atliekų deginimo gamyklos (Vilniaus kogeneracinè jègainè, Kauno kogeneracinè jègainè ir UAB „Fortum Klaipėda“), kuriose galima sudeginti iki $550000 \mathrm{t} /$ metus komunalinių atliekų. Deginant $1 \mathrm{t}$ komunalinių atliekų vidutiniškai susidaro apie $20-25 \%$ šlako (dugno pelenų) ir apie 2-5\% lakiųjų pelenų. Per metus Lietuvoje veikiančiose kogeneracinèse jëgainèse lakiųjų pelenų gali susidaryti apie 10 000-15 $000 \mathrm{t}$, dugno pelenų (šlako) - apie 100 000-130 $000 \mathrm{t} / \mathrm{me}-$ tus (VKJ, 2017; LR statistikos departamentas, 2020). Lakiųų ir dugno pelenų išvežimas i sąvartynus yra brangus ir neigiamai veikia šalies ekologini balansą, todèl tokių atliekų antrinio naudojimo poreikis yra akivaizdus.

Šiuo metu Lietuvoje komunalinių deginimo atliekų lakieji ir dugno pelenai nèra utilizuojami, nors tokių atliekų naudojimas sumažintų aplinkos taršą bei būtų tausojami gamtos ištekliai. Todèl šiame darbe sprendžiamos kogeneracinèse jègainèse susidarančių lakiụjų pelenų, kuriuose yra didelis sunkiųjų metalų, chloridų, sulfatų kiekis, o jie pagal Europos atliekų katalogą priskiriami pavojingosioms atliekoms, bei dugno pelenų naudojimo statybinei keramikai gaminti su lengvai lydžiu moliu galimybės. Kuriami ir tiriami statybinès keramikos gaminiai, nagrinejjamas lakiujų ar dugno pelenų poveikis keraminių šukių struktūrai ir savybėms, ịvertinti aplinkosauginiai naudojimo aspektai.

\section{Tyrimų objektas}

Statybinè keramika su kogeneracinėse jėgainėse po komunalinių atliekų deginimo susidarančiais lakiaisiais ir dugno pelenais. 


\section{Darbo tikslas}

Ištirti keraminių šukių, pagamintų naudojant lengvai lydų molį ir komunalinių atliekų deginimo ịrenginiuose susidarančius lakiuosius bei dugno pelenus, struktūrą ir savybes.

\section{Darbo uždaviniai}

Darbo tikslui pasiekti darbe reikia spręsti šiuos uždavinius:

1. Ištirti komunalinių atliekų deginimo įrenginiuose susidarančių lakiųjų ir dugno pelenų sudètị ir struktūrą, ịvertinti jų toksiškumą.

2. Ivvertinti lakiujų ir dugno pelenų poveikị keraminių šukių mineraloginei sudèčiai ir nustatyti struktūros formavimosi ypatumus.

3. Nustatyti lakiųų ir dugno pelenų poveikị degtų keraminių šukių fizikinèms ir mechaninėms charakteristikoms, struktūros rodikliams ir ilgaamžiškumui.

4. Pateikti rekomendacijas dèl lakiujų ir dugno pelenų naudojimo statybinès keramikos dirbinių gamyboje.

\section{Tyrimų metodika}

Disertacijoje taikomi analitiniai ir eksperimentiniai tyrimo metodai. Pagrindinès statybinès keramikos savybès buvo nustatomos remiantis tokių gaminių standartiniais bandymo metodais (LST EN 771, LST EN 772) bei nestandartizuotomis tyrimo metodikomis. Struktūrai vertinti buvo taikomi skenuojančiosios elektroninès mikroskopijos, rentgenografinès, termografinès analizès metodai. Eksperimentiniams duomenims apdoroti ir jų patikimumui įvertinti buvo taikyti matematiniai ir statistiniai metodai.

\section{Darbo mokslinis naujumas}

Nustatyti keraminès šukès, naudojant kogeneracinèse jëgainèse po komunalinių atliekų deginimo susidarančius lakiuosius ir dugno pelenus, struktūros formavimosi ypatumai, kai porų susidarymą ir mineraloginės sudèties pokyčius lemia lakiujų ir dugno pelenų dalelių struktūra ir sudetis, fizikiniai ir cheminiai procesai, vykstantys molio ir lakiųų pelenų bei molio ir dugno pelenų sistemose. 
Tai leidžia statybinès keramikos gaminiuose stabilizuoti lakiuosiuose ir dugno pelenuose esančius sunkiụjų metalų, chloridų bei sulfatų jonus, kai naudojamas lengvai lydus molis.

\section{Darbo rezultatų praktinè reikšmè}

Tyrimų rezultatai gali būti naudojami statybinès keramikos dirbinių gamyboje, sprendžiant po komunalinių atliekų deginimo susidarančių lakiųjų ir dugno pelenų antrinio naudojimo aplinkosauginius klausimus. Tokių atliekinių priedų naudojimas statybinès keramikos gamyboje padeda utilizuoti pavojingas lakiujų pelenų ir dugno pelenų atliekas, sutaupyti natūralias iškastines žaliavas bei sukurti statybinès keramikos gaminius, kurie net gyvavimo ciklo pabaigoje, ivertinant sunkiụjų metalų, chloridų bei sulfatų išsiplovimo vertes, būtų priskiriami inertinių atliekų kategorijai. Remiantis atliktais tyrimais pateiktos rekomendacijos dèl lakiụjų ir dugno pelenų, susidarančių po komunalinių atliekų deginimo, naudojimo statybinès keramikos dirbinių gamyboje.

\section{Ginamieji teiginiai}

1. Lakieji ir vandeniu apdoroti lakieji pelenai, lemia kalcio sulfato mineralo keraminèje šukejje susidarymą, keičia keraminès šukès struktūrą suformuodami papildomas poras, tai 3,7-8 \% didina keraminių šukių bendrajj poringumą ir neigiamai veikia ilgaamžiškumą, lyginant su keramine šuke be lakiųjų pelenų.

2. Dugno pelenai, savo sudètyje turintys ne mažiau kaip $45 \% \mathrm{SiO}_{2}$, gali būti naudojami kaip lengvai lydų molị liesinantis priedas, kuris 2,23,0 \% mažina keraminių šukių susitraukimą. $5 \%$ dugno pelenų priedas leidžia pasiekti analogiškas gniuždymo stiprio bei $8 \%$ mažesnes keraminių šukių tankio vertes, lyginant su keramine šuke be dugno pelenų.

\section{Darbo rezultatụ aprobavimas}

Disertacijos tema paskelbti septyni straipsniai: du straipsniai - mokslo žurnaluose, įtrauktuose i Clarivate Analytic Web of Science duomenu bazes, turinčiuose citavimo rodiklị, sąrašą, du - Clarivate Analytics Web of Science duomenų bazès, 
"Conference Proceedings“ leidiniuose, trys straipsniai - kitų tarptautinių duomenų bazių leidiniuose. Remiantis tyrimų rezultatais gautas Lietuvos Respublikos patentas.

Disertacijoje atliktų tyrimų rezultatai buvo paskelbti septyniose mokslinėse konferencijose Lietuvoje ir kitose šalyse:

- Tarptautineje konferencijoje „MBMST 2019: the 13th international conference on modern building materials, structures and techniques" 2019 m., Vilniuje;

- Tarptautineje konferencijoje (tarptautiniame simpoziume) „WMCAUS 2019: the 4th world multidisciplinary civil engineering-architecture-urban planning symposium“ 2019 m., Prahoje, Čekijoje;

- Tarptautineje konferencijoje „IMST 2019: the 4th international conference on innovative materials, structures and technologies" 2019 m., Rygoje, Latvijoje;

- Tarptautiniame forume „Сотрудничество - катализатор инновационного роста: 3, 5 Белорусско-Прибалтийский форум“ 2017 m., 2019 m. Minske, Baltarusijoje;

- Tarptautineje konferencijoje „MALTOVINY 2018” 2018 m., Brno, Čekijoje;

- Tarptautineje konferencijoje „Архитектурно-строительный комплекс: проблемы, перспективы, инновации: международной научной конференции, посвященной 50-летию Полоцкого государственного университета“" $2018 \mathrm{~m}$. Novopolocke, Baltarusijoje;

- 21-ojoje Lietuvos jaunujų mokslininkų konferencijoje „Mokslas - Lietuvos ateitis“ 2018 m., kovo 14 ir 20 d., Vilniuje.

\section{Disertacijos struktūra}

Disertaciją sudaro įvadas, trys skyriai, bendrosios išvados, rekomendacijos, literatūros ir šaltinių bei autorès publikacijų disertacijos tema sąrašai, santrauka anglu kalba ir du priedai.

Disertacijos apimtis 130 puslapių, neįskaitant priedu, tekste panaudotos $2 \mathrm{nu}-$ meruotos formulès, 57 paveikslai ir 20 lentelių. Rašant disertaciją buvo panaudoti 146 literatūros šaltiniai. 



\section{1}

\section{Komunalinių deginimo atlieku lakiuju ir dugno pelenų naudojimo statybinès keramikos gamyboje mokslinių tyrimų apžvalga}

Skyriuje analizuojami literatūros šaltiniai apie komunalinių atliekų naudojimo ir utilizavimo civilinès ir/ar statybos inžinerijos reikmėms galimybes ir ypatumus. Nagrinejjama komunalinių deginimo atliekų (lakiụjų ir dugno pelenų) paruošimo technologija, cheminè, mineraloginè sudètis, makro- ir mikrostruktūra, savybès. Apžvelgiamos galimybės naudoti lakiuosius ir dugno pelenus keraminių mūro dirbinių gamyboje, analizuojami ekologiniai naudojimo aspektai.

Skyriaus tematika kartu su bendraautoriais paskelbti trys straipsniai (Kizinievič et al., 2019a; Voišnienè \& Kizinievič, 2018; Voišnienė et al., 2018), skaityti pranešimai respublikinejje 21-ojoje Lietuvos jaunujų mokslininkų konferencijoje „Mokslas - Lietuvos ateitis“ 2018 m., kovo 14 ir 20 d.

Europos Sajungos komunalinių atliekų tvarkymo politika siekiama sumažinti komunalinių atliekų kiekius bei jų neigiamą poveikị aplinkai. Tačiau kiekvienais metais (tai rodo duomenys, kuriuos pagal reglamentą (EB) Nr. 2150/2002 ES valstybės narès teikia atliekų susidarymo, naudojimo ir šalinimo kiekius) ES tokių atliekų kiekiai, priklausomai nuo šalies išsivystymo lygio bei ekonominių šalies 
rodiklių, auga. Todèl 7-ojoje aplinkosaugos veiksmų programoje (Environmental Action Programme to 2020) nustatyti šie atliekų politikos ES prioritetiniai tikslai:

- mažinti susidarančių atliekų kiekí;

- kuo labiau padidinti perdirbimo ir pakartotinio atliekų naudojimo mąstą;

- deginti tik perdirbti netinkamas medžiagas;

- laipsniškai pereiti prie to, kad į sąvartynus būtų vežamos tik perdirbti ir naudoti netinkamos atliekos;

- užtikrinti visapusišką atliekų politikos tikslų igyvendinimą visose ES valstybėse narèse.

Vienu iš prioritetų siekiama po rūšiavimo likusias, netinkamas perdirbti bei pakartotinai naudoti, bet turinčias energetinę vertę komunalines atliekas naudoti energijos gamybai.

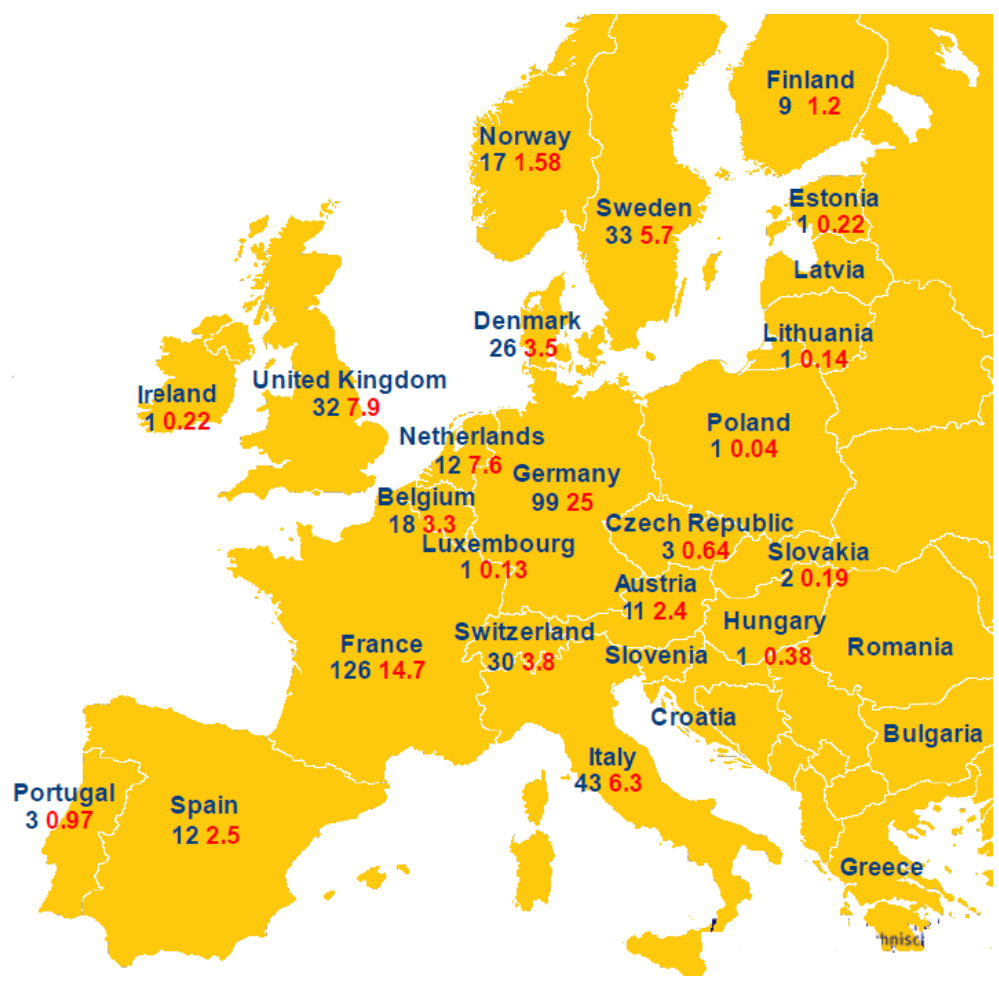

1.1 pav. Atliekų perdirbimo ị energiją gamyklos Europoje: Europos Sajungoje veikiančių „Atliekų perdirbimo ị energiją“" gamyklų skaičius ir gautos energijos kiekiai (išskyrus pavojingujų atliekų deginimo įmones), milijonais tonų (Brouwers et al., 2017)

Fig. 1.1. Waste-to-Energy plants in Europe: Waste-to-Energy Plants operating in the

European Union (not including hazardous waste incineration plants) and Waste thermally treated in Waste-to-Energy Plants, in million tonnes (Brouwers et al., 2017) 
1.1 paveiksle pateiktas ES esančių komunalinių atliekų deginimo gamyklų ịvairiose šalyse skaičius ir gautos energijos kiekis. Komunalinių atliekų deginimas jègainèse, siekiant gauti energiją per pastaraji dešimtmeti, gerokai padidèjo (Brouwers et al., 2017; Malinauskaitè et al., 2017).

Komunalinių atliekų apdorojimo procesas, siekiant jas naudoti energijos gamybai, apima atliekų termini apdorojimą, kuriame komunalinès atliekos deginamos maždaug $1000{ }^{\circ} \mathrm{C}$ temperatūroje. Terminio apdorojimo metu komunalinių atliekų masė sumažèja 65-80 \%, tūris - 85-90 \% (Bertolini et al., 2004).

Norint iggyvendinti anksčiau išvardytus ES keliamus atliekų tvarkymo tikslus, Lietuvoje veikiančios trys komunalinių atliekų deginimo jègainès (Klaipėdoje, Kaune ir Vilniuje) per metus galès sudeginti apie 550 tūkst. tonų atliekų, kad iki $2030 \mathrm{~m}$. tokių atliekų i sąvartyną patektų ne daugiau kaip $10 \%$. Vilniuje planuojama apdoroti apie 160 tūkst. tonų atliekų per metus. Tokiu būdu neišvengiamai susidarys degimo proceso šalutiniai produktai, t. y. lakieji ir dugno pelenai, kurie pagal galimybes turi būti tinkamai naudojami ar/ir utilizuojami. Netinkamai sutvarkytos bei nepašalintos iš sąvartynų degimo metu susidariusios atliekos gali kelti riziką aplinkai ir žmonių sveikatai.

\subsection{Dugno ir lakiujų pelenų ịvertinimas prieš naudojimą statybos pramonèje}

\subsubsection{Dugno ir lakiujų pelenų naudojimo aplinkosauginiai reikalavimai (toksiškumo įvertinimas)}

Komunalinių kietujų atliekų deginimas yra gerai žinoma, gerai ịvaldyta technologija ir priimtinas apdorojimo būdas, skirtas sumažinti komunalinių kietujų atliekų kiekị ir kartu gauti energijos. Deginant komunalines atliekas daugiausia susidaro dugno pelenu - apie 95-97 \%, likusi dalis (3-5 \%) - lakieji pelenai (Van Herck et al., 2000; Wunsch et al., 1996). Europos atliekų kataloge lakieji pelenai klasifikuojami kaip pavojingosios atliekos (kodas 1901 13), o šlakas ir pelenai priskiriamas nepavojingujų atliekų grupei (kodas 1901 12) (European Waste Catalogue (EWC), 2015).

Europoje, siekiant naudoti komunalinių atliekų deginimo šlaką ir nepavojingus pelenus, aplinkosauginiai reikalavimai remiasi standartinėmis bandymų procedūromis (ISWA, 2006), nustatant ịvairių pavojingų cheminių elementų išsiplovimo ribines vertes. Ivvairių šalių išsiplovimo verčiu palyginimas pateiktas 1.1 lenteleje (An et al., 2014). Kaip matoma iš pateiktų duomenų, skirtingos šalys, siekdamos igyvendinti savo šalies aplinkosauginius reikalavimus ir nustatydamos 
išsiplovimo ribines vertes, naudoja skirtingus skysčio ir kietosios medžiagos santykius. Taip pat skirtingose šalyse skiriasi ir chloridų, sulfatų bei sunkiųjų metalų ribinès išsiplovimo vertès.

1.1 lentelè. Dugno pelenų išplovimo ribinès vertės ịvairiose šalyse (An et al., 2014) Table 1.1. Leaching limits for bottom ash from different countries (An et al.,2014)

\begin{tabular}{|l|l|l|l|l|}
\hline \multirow{2}{*}{ Anijonai, metalai } & \multicolumn{4}{|l}{ Šlis } \\
\cline { 2 - 5 } & $\begin{array}{l}\text { Olandija } \\
\left(\mathrm{L} / \mathrm{S}^{*}=1-10\right), \\
2005\end{array}$ & $\begin{array}{l}\text { Danija } \\
\left(\mathrm{L} / \mathrm{S}^{*}=2\right), \\
2000\end{array}$ & $\begin{array}{l}\text { Vokietija } \\
\left(\mathrm{L} / \mathrm{S}^{*}=5\right), \\
2004\end{array}$ & $\begin{array}{l}\text { Prancūzija } \\
\left(\mathrm{L} / \mathrm{S}^{*}=5\right), \\
1994\end{array}$ \\
\hline $\mathrm{Cl}^{-}$ & 440 & 300 & 125 & - \\
\hline $\mathrm{F}^{-}$ & 14,4 & - & - & - \\
\hline $\mathrm{SO}_{4}^{2-}$ & 3,250 & 400 & 300 & 500 \\
\hline $\mathrm{Na}$ & - & 150 & - & - \\
\hline $\mathrm{As}$ & 0,35 & 0,005 & - & 0,1 \\
\hline $\mathrm{Ba}$ & 7,75 & 0,4 & - & - \\
\hline $\mathrm{Pb}$ & 0,41 & 0,01 & 0,025 & 0,5 \\
\hline $\mathrm{Cd}$ & 0,00305 & 0,004 & 0,0025 & 0,05 \\
\hline $\mathrm{Cr}$ & 0,06 & 0,05 & 0,1 & 0,05 \\
\hline $\mathrm{Cu}$ & $0,165^{\mathrm{a}}$ & 0,2 & 0,15 & - \\
\hline $\mathrm{Hg}$ & 0,00375 & 0,0001 & 0,00005 & 0,01 \\
\hline $\mathrm{Mn}$ & - & 0,1 & - & - \\
\hline $\mathrm{Ni}$ & 0,175 & 0,007 & 0,02 & - \\
\hline $\mathrm{Zn}$ & 0,7 & 0,15 & 0,15 & - \\
\hline $\mathrm{Co}$ & 0,115 & - & - & - \\
\hline $\mathrm{Mo}$ & $0,13^{\mathrm{a}}$ & - & - & - \\
\hline $\mathrm{Sb}$ & $0,06^{\mathrm{a}}$ & - & - & - \\
\hline $\mathrm{Se}$ & 0,0135 & - & - & - \\
\hline $\mathrm{Sn}$ & 0,115 & - & - & - \\
\hline $\mathrm{V}$ & 4,8 & - & - & - \\
\hline & $\mathrm{Sk}$ & & - & - \\
\hline
\end{tabular}

*Skysčio ir kietosios medžiagos santykis; a - mažiau griežtos $\mathrm{Cu}, \mathrm{Mo}$ ir $\mathrm{Sb}$ ribinès vertès. 
Europos standartizacijos komiteto norminiai dokumentai (LST EN 124574:2003), remdamiesi išsiplovimo kriterijais, numato tris kategorijas: 1 ir 2 kategorijos turi griežtus išsiplovimo kriterijus, o 3 kategorija - švelnesnius kriterijus. Šlakas ir pelenai dažniausiai patenka ị 3 kategoriją, o dèl didelių neorganinių likučių beveik niekada nepatenka į 1 kategoriją.

Verta paminèti, kad kiekviena šalis turi savo papildomus normatyvinius dokumentus, kurie nustato komunalinių deginimo atliekų naudojimo statybos ir kitu sričių pramonèje galimybes.

Vokietijoje (ISWA, 2006) dugno pelenai prieš naudojant ịvairių medžiagu gamybos reikmèms, turi būti apdoroti: atskirti juodieji ir spalvotieji metalai; atliktas dugno pelenų sendinimas; bendras organinès anglies kiekis neturi viršyti $1,0 \%$. Norint naudoti šlaką kaip antrinę žaliavą statyboje, taip pat turi būti nustatytas žaliavos tankis, granuliometrinè sudètis, stiprumas ir atlikti atsparumo šalčiui tyrimai.

Prancūzijoje komunalinių deginimo atliekų šlakas ir pelenai pagal išsiplovimo tyrimus (Mehu et al., 1991) klasifikuojami ị V, M ir L kategorijas. V kategorijai priskiriami dugno pelenai, kurie turi nedidelị išsiplovimo potencialą ir tinkami naudoti automobilių kelių, automobilių aikštelių statyboje ir įvairiems pylimams įrengti. M kategorijai priskiriamas šlakas ir pelenai turi būti sendinami ne mažiau kaip 12 mėnesių, vèliau atliekami išsiplovimo tyrimai, siekiant patikrinti, ar žaliava gali būti naudojama įvairių medžiagų gamyboje. L kategorijai priskirtų dugno pelenų pakartotinai naudoti negalima.

Pagal Lietuvoje galiojantị normatyvinị dokumentą (LR AM ịsakymas D1805), civilinès ir statybų inžinerijos tikslams galima naudoti šlaką ir pelenus, kai metalų kiekis juose ne daugiau kaip $5 \%$, bendros organinès anglies kiekis ne didesnis kaip $3 \%$ jo svorio, iškaitinimo nuostolis ne didesnis kaip $6 \%$, o išplovimo rodikliai neviršija 1.2 lentelèje nurodytų verčių. Toks šlakas ir pelenai gali būti naudojami kaip statybinè medžiaga ar jos pakaitalas, pvz., keliams tiesti, pastatų pamatams ir pan. Jei po apdorojimo šlako ir pelenų vertès viršija 1.2 lentelèje nurodytas vertes, jie turi būti tvarkomi kaip atlieka, pvz., atliekų sluoksniams perdengti sąvartynuose, kaip užpildas laikiniesiems keliams atliekų sąvartynuose tiesti ir pan.

Lietuvoje, kaip ir visoje Europoje, degimo metu susidarantys lakieji pelenai, kuriuose yra pavojingujų cheminių medžiagų (sunkiujjų metalų, chloridų, sulfatų), dažniausiai perduodami utilizuoti licencijuotoms atliekų tvarkymo įmonėms, kurios jas išgabena ị tam skirtas šalinimo vietas. Tokios specializuotos vietos įrengtos Lenkijoje, Norvegijoje, Vokietijoje, Švedijoje.

KDA lakiųu pelenų toksiškumas, t. y. sunkiujų metalų, chloridų ir sulfatų išsiplovimas vertinamas pagal Europos Parlamento ir Tarybos direktyvą 2003/33/EC, kurioje nustatomi atliekų prièmimo ị sąvartynus kriterijai ir tvarka. 
Pagal minètą direktyvą atliekos klasifikuojamos ị inertines, nepavojingąsias ir pavojingąsias atliekas.

1.2 lentelė. Išplovimo ribinès vertès, kai šlakas ir pelenai gali būti naudojami civilinèje ir statybos inžinerijoje (LR AM įsakymas D1-805)

Table 1.2. Leaching limit values, when slag and ash may be used in civil and construction engineering (LR AM order D1-805)

\begin{tabular}{|c|c|c|}
\hline Parametrai & Matavimo vienetai & Vertès \\
\hline Spalva & - & İvertinama mėginiui apibūdinti \\
\hline Drumstumas & - & İvertinama mėginiui apibūdinti \\
\hline Kvapas & - & İvertinama mėginiui apibūdinti \\
\hline $\mathrm{pH}$ & vnt. & $7-13$ \\
\hline Elektros laidumas & $\mu \mathrm{S} / \mathrm{cm}$ & 6000 \\
\hline Ištirpusi organinè anglis & $\mu \mathrm{g} / 1$ & İvertinama mėginiui apibūdinti \\
\hline Arsenas & $\mu \mathrm{g} / 1$ & İvertinama mėginiui apibūdinti \\
\hline Švinas & $\mu \mathrm{g} / \mathrm{l}$ & 50 \\
\hline Kadmis & $\mu \mathrm{g} / \mathrm{l}$ & 3 \\
\hline Chromas & $\mu \mathrm{g} / 1$ & 200 \\
\hline Varis & $\mu \mathrm{g} / \mathrm{l}$ & 150 \\
\hline Nikelis & $\mu \mathrm{g} / 1$ & 40 \\
\hline Gyvsidabris & $\mu \mathrm{g} / 1$ & 1 \\
\hline Cinkas & $\mu \mathrm{g} / 1$ & 300 \\
\hline Chloridai & $\mathrm{mg} / \mathrm{l}$ & 1000 \\
\hline Sulfatai & $\mathrm{mg} / \mathrm{l}$ & 2000 \\
\hline Cianidai & $\mathrm{mg} / \mathrm{l}$ & 0,020 \\
\hline
\end{tabular}




\subsubsection{Dugno ir lakiųjų pelenų sudètis ir struktūros ịvertinimas}

Dugno pelenų cheminè sudètis gali skirtis, tai priklauso nuo pradinių žaliavų sudèties, degimo režimo, aukščiausios degimo temperatūros, dugno pelenų apdorojimo technologijos. Atlikti moksliniai tyrimai (1.3 lentelè) parodè, kad deginant komunalines atliekas susidariusių dugno pelenų cheminè sudètis, priklausomai nuo anksčiau išvardytų technologinių parametrų, gali skirtis labai plačiai.

Kaip matoma iš pateiktų duomenų, $\mathrm{SiO}_{2}$ kiekis gali skirtis 5,44-49,38 \%, $\mathrm{CaO}$ kiekis - 14,68-42,5 \%, taip pat yra nemaži $\mathrm{Al}_{2} \mathrm{O}_{3}, \mathrm{Fe}_{2} \mathrm{O}_{3}, \mathrm{Na}_{2} \mathrm{O}$ oksidų svyravimai. Dugno pelenuose gali skirtis ir sunkiujų metalų $(\mathrm{Cu}, \mathrm{Cd}, \mathrm{Pb}, \mathrm{Zn}, \mathrm{As}, \mathrm{Cr}$, Mo) bei jų oksidų kiekiai. Norint naudoti dugno pelenus kaip antrinę žaliavą, sunkiujų metalų buvimas juose yra ypač nepageidaujamas, nes dèl jų apribojamos dugno pelenų naudojimo galimybès (Dou et al., 2017).

Atliekant dugno pelenų mineraloginius tyrimus dažniausiai nustatomi $\mathrm{SiO}_{2}$, $\mathrm{CaCO}_{3}$ mineralai, taip pat randama $\mathrm{Al}_{2} \mathrm{O}_{3}, \mathrm{Fe}_{2} \mathrm{O}_{3}, \mathrm{~K}_{2} \mathrm{O}, \mathrm{MgO}$ mineralų (Lin et al., 2006; Wei et al., 2011).

Ivertinant kitų šalių, kurios naudoja dugno pelenus kaip antrines žaliavas jau daug metų, patirtị, dugno pelenų cheminès sudèties nepastovumas ir sunkiųjų metalu juose buvimas akcentuojamas kaip didžiausia problema, su kuria susiduria mokslininkai, vertinantys dugno pelenų naudojimo statybinèse medžiagose galimybes.

Dugno pelenų dalelių mikrostruktūra parodo (1.2 pav.), kad dalelès būna labai skirtingos: apvalios, kampuotos, netaisyklingos formos, taip pat matomos dalelių nuolaužos (Wongsa et al., 2017; Zhu et al., 2016). Vidutinis dalelių dydis apie $5 \mu \mathrm{m}$ (Wongsa et al., 2017). Kaip jau minèta, dalelių struktūra priklauso nuo degimo parametrų ir paruošimo technologijos.

Atlikta literatūros analizè parodè, kad deginant komunalines atliekas susidariusių lakiųuu pelenų cheminè sudètis būna labai skirtinga (1.4 lentelè). Pagrindiniai lakiųju pelenų komponentai yra $\mathrm{CaO}, \mathrm{SiO}_{2}$ ir $\mathrm{Al}_{2} \mathrm{O}_{3}$, taip pat randamas nemažas chloridų kiekis. Kai kurie autoriai nustato gana didelius kaitinimo nuostolius (dažniausiai matuojami $1000-1200{ }^{\circ} \mathrm{C}$ temperatūroje). Dideli kaitinimo nuostoliai rodo, kad lakiuosiuose pelenuose yra dideli kiekiai neorganinių druskų, tokių kaip kalcitas, chloridai ir sulfatai ( $\mathrm{Li}$ et al., 2014). Lakiuosiuose pelenuose randami gana dideli sunkiųjų metalų, tokių kaip $\mathrm{Zn}, \mathrm{Pb}, \mathrm{Cu}, \mathrm{Cd}, \mathrm{Cr}$ ir kt., kiekiai (Shi \& Kan, 2009; Aubert et al., 2006; Tang et al., 2017). 
1.3 lentelè. Degant komunalinėms atliekoms susidariusių dugno pelenų cheminè sudètis

Table 1.3. Chemical composition of bottom ash from municipal waste incineration

\begin{tabular}{|c|c|c|c|c|c|c|c|c|c|c|}
\hline \multirow{2}{*}{ 兽: } & \multicolumn{10}{|c|}{ Cheminè sudètis, $\%$} \\
\hline & 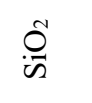 & 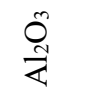 & ర్త & 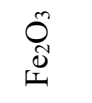 & $\sum_{\substack{0 \\
\sum}}^{0}$ & $\begin{array}{l}0 \\
\stackrel{N}{1}\end{array}$ & $\begin{array}{l}0 \\
\text { ָ̃ } \\
Z\end{array}$ & $\tilde{\wp}$ & $\stackrel{0}{\mathscr{C}}$ & $\stackrel{*}{:}:$ \\
\hline $\begin{array}{l}\text { Pan et al., } \\
2008\end{array}$ & 30,66 & 12,25 & 24,85 & 3,60 & 2,29 & 1,50 & 1,69 & 5,18 & - & 17,98 \\
\hline $\begin{array}{l}\text { Andreola } \\
\text { et al., } \\
2008\end{array}$ & 46,7 & 6,86 & 26,3 & 4,69 & 2,22 & 0,88 & 4,62 & 2,18 & 0,77 & 3,93 \\
\hline $\begin{array}{l}\text { Gines } \\
\text { et al., } \\
2009\end{array}$ & 49,38 & 6,58 & 14,68 & 8,38 & 2,32 & 1,41 & 7,78 & 0,57 & - & 8,87 \\
\hline $\begin{array}{l}\text { Shih } \\
\text { et al., } \\
2003\end{array}$ & 29,4 & 18 & 27,2 & 13,3 & 1,6 & 0,9 & 3,6 & - & - & 6 \\
\hline $\begin{array}{l}\text { Saikia } \\
\text { et al., } \\
2007\end{array}$ & 12,01 & 8,1 & 13,86 & 1,21 & 2,62 & 7,41 & 17,19 & - & - & 37,61 \\
\hline $\begin{array}{l}\text { Qian } \\
\text { et al., } \\
2006\end{array}$ & 5,44 & 3,1 & 42,55 & 1,69 & 1,83 & 4,31 & 4,82 & 12,73 & 0,92 & 20,9 \\
\hline $\begin{array}{l}\text { Garcia- } \\
\text { Lodeiro } \\
\text { et al., } \\
2016\end{array}$ & 6,77 & 7,27 & 30,1 & 11,97 & 3,78 & - & 3,37 & 2,95 & - & 31,33 \\
\hline $\begin{array}{l}\text { Wongsa } \\
\text { et al., } \\
2017\end{array}$ & 15,8 & 0,9 & 38,1 & 4,2 & 3,5 & 7,3 & 0,2 & 1,5 & 0,3 & 26,5 \\
\hline $\begin{array}{l}\text { Taurino } \\
\text { et al., } \\
2017\end{array}$ & 46,8 & 9,8 & 18,6 & 4,3 & 2,9 & 1,0 & 4,5 & 1,0 & 0,7 & 10,4 \\
\hline $\begin{array}{l}\text { Colangelo } \\
\text { et al., } \\
2015\end{array}$ & 7,93 & 7,61 & 35,11 & 2,03 & 3,24 & 3,85 & 3,36 & 9,12 & 1,85 & 24,78 \\
\hline
\end{tabular}

*Gali būti $\mathrm{ZnO}, \mathrm{PbO}, \mathrm{MnO}_{2}, \mathrm{Cl}, \mathrm{Cr}, \mathrm{Cd}$ ir kiti. 


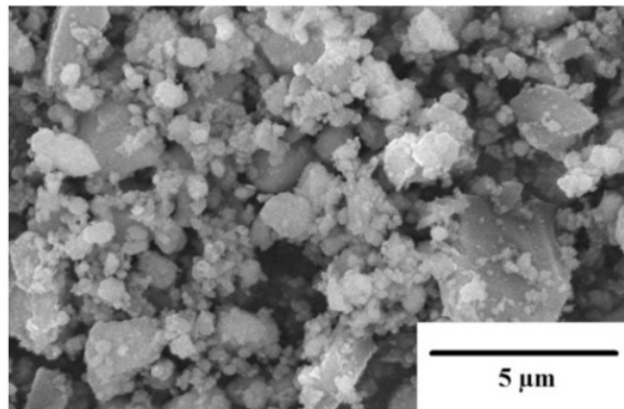

a)

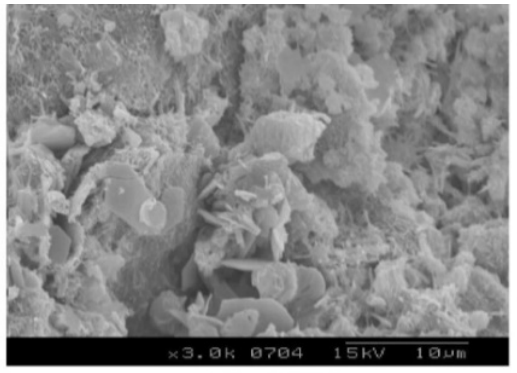

(c) $\times \mathbf{3 0 0 0}$

b)

1.2 pav. Dugno pelenų dalelès mikrostruktūra:

a) Wongsa et al., 2017; b) Zhu et al., 2016

Fig. 1.2. Investigation of bottom ash particle microstructure:

a) Wongsa et al., 2017; b) Zhu et al., 2016

Atliekant lakiujų pelenų mineraloginius tyrimus, dažniausiai nustatomi $\mathrm{SiO}_{2}$, $\mathrm{NaCl}, \mathrm{KCl}, \mathrm{CaSO}_{4}, \mathrm{CaCO}_{3}$ mineralai (Remond et al., 2002; Shi et al., 2009, Liu et al., 2018). Taip pat gali susidaryti ir $\mathrm{K}_{2} \mathrm{Al}_{2} \mathrm{Si}_{2} \mathrm{O}_{8} \cdot 3,8 \mathrm{H}_{2} \mathrm{O}$, $\mathrm{AlCl}_{3} \cdot 4 \mathrm{Al}(\mathrm{OH})_{3} \cdot 4 \mathrm{H}_{2} \mathrm{O}, \quad \mathrm{Ca}_{3} \mathrm{Si}_{2} \mathrm{O}_{7}, \quad \mathrm{Ca}_{9} \mathrm{Si}_{6} \mathrm{O}_{21} \cdot \mathrm{H}_{2} \mathrm{O}, \quad \mathrm{Ca}_{2} \mathrm{SiO}_{4} \cdot 0,35 \mathrm{H}_{2} \mathrm{O}, \quad \mathrm{CaCl}_{2}$ (Haiying et al., 2011, 2007).

Mokslininkų atlikti lakiųų pelenų mikrostruktūros tyrimai parodo, kad dalelès gali būti labai skirtingos formos, dydžio (Jin et al., 2016; Wongsa et al., 2017) (1.3 pav.). Dalelių formos ir dydžio skirtumui ịtakos turi komunalinių atliekų sudètis, deginimo technologiniai parametrai, todèl lakiujų pelenų dalelių poveikis keraminių šukių struktūrai ir savybėms taip pat gali būti skirtingas.

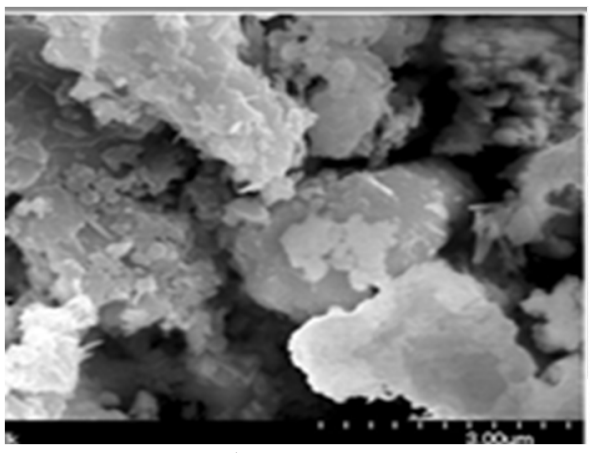

a)

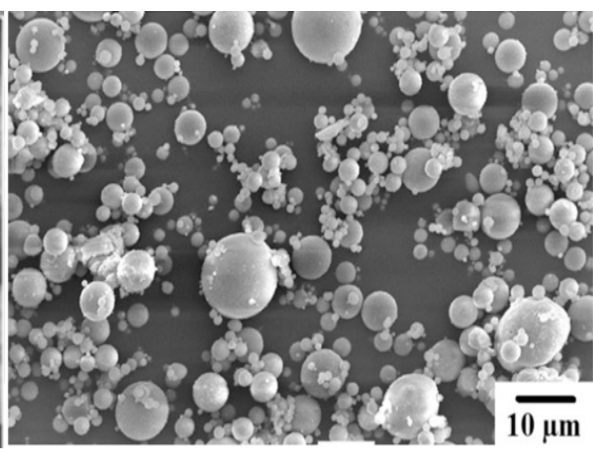

b)

1.3 pav. Lakiujų pelenų mikrostruktūra: a) Jin et al., 2016; b) Wongsa et al., 2017

Fig. 1.3. Investigations of fly ash microstructure: a) Jin et al., 2016;

b) Wongsa et al., 2017 
1.4 lentelè. Degant komunalinėms atliekoms susidariusių lakiụjų pelenų cheminė sudètis

Table 1.4. Chemical composition of municipal solid waste incineration fly ash

\begin{tabular}{|c|c|c|c|c|c|c|c|c|c|c|c|}
\hline \multirow[b]{2}{*}{ 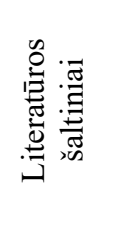 } & \multicolumn{11}{|c|}{ Cheminè sudètis, \% } \\
\hline & $\stackrel{0}{\infty}$ & 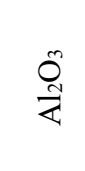 & O & $\overbrace{\mathbb{N}}^{\infty}$ & ${ }_{\substack{\infty \\
\Sigma}}$ & $\begin{array}{l}0 \\
\mathscr{N}\end{array}$ & $\begin{array}{l}0 \\
\text { ż̃ }\end{array}$ & 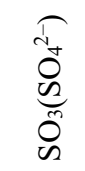 & $\bar{U}$ & ${ }^{*} \dot{\vec{u}}$ & 澏 \\
\hline $\begin{array}{l}\text { Pan } \\
\text { et al., } \\
2008\end{array}$ & 30,66 & 22,25 & 24,85 & 3,60 & 4,29 & 1,50 & 1,69 & 5,18 & - & - & 4,82 \\
\hline $\begin{array}{l}\text { Ye et al., } \\
2016\end{array}$ & 20,48 & 10,16 & 27,44 & 4,25 & - & 2,17 & 3,15 & 4,45 & 5,77 & 12,91 & 9,22 \\
\hline $\begin{array}{l}\text { Li et al., } \\
2014\end{array}$ & 16,4 & 4,7 & 31,5 & 5,9 & 6,9 & - & - & 6,3 & 14,5 & 27,5 & - \\
\hline $\begin{array}{l}\text { Wang } \\
\text { et al., } \\
2018\end{array}$ & 3,18 & 1,17 & 58,6 & 0,84 & 2,2 & 4,25 & 5,44 & 5,38 & 16,81 & - & 1,44 \\
\hline $\begin{array}{l}\text { Shi } \\
\text { et al., } \\
2009\end{array}$ & 24,50 & 7,42 & 23,37 & 4,01 & 2,72 & 4,60 & 4,00 & 12,03 & 10,00 & 22,04 & - \\
\hline $\begin{array}{l}\text { Liu } \\
\text { et al., } \\
2018\end{array}$ & 4,22 & 1,33 & 49,6 & 2,03 & 1,66 & 5,17 & 2,54 & 6,15 & 12,48 & 26,34 & - \\
\hline
\end{tabular}

*Kaitinimo nuostoliai.

\subsection{Lakiūjų ir dugno pelenų ịtaka statybinès keramikos savybẻms ir struktūrai}

Dažniausiai statybinès keramikos dirbinių gamyboje naudojamos tradicinės žaliavos, t. y. molis, smèlis, sutrupintų plytų skaldelè, tačiau pastaruoju metu vis dažniau dèmesys atkreipiamas ị ịvairių technogeninių žaliavų ir atliekų antrinị naudojimą. Komunalinių deginimo atliekų (dugno ir lakiujjų pelenų) naudojimas keraminiams dirbiniams gaminti leistų sutaupyti energijos ir išsaugoti tradicines žaliavas, padidintų žaliavų išteklių naudojimo efektyvumą, gerokai prisidètų ir padètų sprendžiant ekologines atliekų šalinimo problemas.

Deginant komunalines atliekas kogeneracinèse jègainèse vyksta ganètinai sudètingi cheminių junginių transformacijos procesai, jų metu suardomi organiniai ir stabilizuojasi neorganiniai junginiai. Kiekvienas elementas dèl savo cheminių 
ir fizikinių savybių skirtingai pasiskirsto tarp dugno, lakiụjų ar dujų fazių. Dugno ir lakiụjų pelenų sudètis bei savybės priklauso nuo krosnies tipo, degimo proceso efektyvumo ir pačios žaliavos. Lakieji pelenai dažniausiai susideda iš išsilydžiusių dalelių, o dugno pelenai iš išsilydžiusių arba tik iš dalies išsilydžiusių bei neišsilydžiusių dalelių (He et al., 2004; Chimenos et al., 1999).

Svarbu atkreipti dèmesị ị sunkiụjų metalu pasiskirstymą tarp skirtingų pelenų. 1.5 lenteleje pateikti duomenys parodo, kurie sunkieji metalai daugiausia nusèda ị dugno pelenus, o kurie yra lakesni, pereina ị lakiuosius pelenus ar dujas (Belevi \& Moench, 2000). Stabiliausi yra sunkieji metalai, kurie lieka dugno pelenuose, t. y. $\mathrm{Cu}, \mathrm{Cr}, \mathrm{Ni}, \mathrm{Fe}, \mathrm{Co}$. Lakiausi sunkieji metalai pereina ị lakiujų pelenu fazę ir dujas: $\mathrm{Cd}, \mathrm{Hg}$, Sb. Kiti sunkieji metalai pasiskirsto panašiu santykiu tarp dugno pelenų ir lakiosios fazès.

1.5 lentelè. Sunkiujų metalų pasiskirstymo koeficientas deginant komunalines atliekas (Belevi \& Moench, 2000)

Table 1.5. Partition coefficient of heavy metals in municipal waste incineration (Belevi $\&$ Moench, 2000)

\begin{tabular}{|l|l|l|l|l|l|l|l|l|l|l|l|}
\hline $\begin{array}{l}\text { Meta- } \\
\text { Atlie-- } \\
\text { kos }\end{array}$ & $\mathrm{Zn}$ & $\mathrm{Pb}$ & $\mathrm{Cu}$ & $\mathrm{Cd}$ & $\mathrm{Hg}$ & $\mathrm{Cr}$ & $\mathrm{Ni}$ & $\mathrm{As}$ & $\mathrm{Fe}$ & $\mathrm{Co}$ & $\mathrm{Sb}$ \\
\hline $\begin{array}{l}\text { Dugno } \\
\text { pelenai }\end{array}$ & 0,52 & 0,59 & 0,97 & 0,1 & 0,0095 & 0,92 & 0,981 & 0,69 & 0,992 & 0,9 & 0,25 \\
\hline $\begin{array}{l}\text { Lakieji } \\
\text { pelenai }\end{array}$ & 0,471 & 0,4 & 0,025 & 0,89 & 0,7465 & 0,077 & 0,017 & 0,306 & 0,008 & 0,097 & 0,74 \\
\hline Dujos & 0,009 & 0,01 & 0,005 & 0,01 & 0,244 & 0,003 & 0,002 & 0,004 & 0 & 0,003 & 0,01 \\
\hline
\end{tabular}

\subsubsection{Dugno pelenụ poveikis keraminių šukių mineraloginei sudéčiai, struktūrai ir savybèms}

Literatūroje (Taurino et al., 2017a; Shih et al., 2003; Giro-Paloma et al., 2017; Lin, 2006; Colangelo et al., 2015; Tang et al., 2015; Lin et al., 2006) nurodoma, kad pagrindiniai komunalinių atliekų dugno pelenų komponentai yra $\mathrm{SiO}_{2}, \mathrm{CaO}$, $\mathrm{Al}_{2} \mathrm{O}_{3}, \mathrm{Fe}_{2} \mathrm{O}_{3}$ ir kt., taip pat randamas nedidelis kiekis sunkiųų metalų. Pagal mineraloginę sudètį dugno pelenuose dažniausiai randami kvarco $\left(\mathrm{SiO}_{2}\right)$, kalcito $\left(\mathrm{CaCO}_{3}\right)$ mineralai, taip pat gali būti gelenito $\left(\mathrm{Ca}_{2} \mathrm{Al}(\mathrm{SiAl}) \mathrm{O}_{7}\right)$, hematito $\left(\mathrm{Fe}_{2} \mathrm{O}_{3}\right)$ mineralų (Yanga et al., 2018; Cheeseman et al., 2005; Vegas et al., 2008; Wongsta et al., 2017). Minèti mineralai dažnai susidaro ir degtų keraminių šukių gamyboje, todèl manoma, kad dugno pelenai kaip priedas tinka jų gamybai. Techninè galimybè naudoti dugno pelenus ịvairiuose keraminiuose gaminiuose 
(ịskaitant plytas, plyteles, stiklo keramiką) bei tokio priedo poveikis aplinkai aptarti Silva et al. $(2017,2019)$ darbuose.

Cheeseman et al. (2003) nustate $1080-1115^{\circ} \mathrm{C}$ temperatūroje apdorotų dugno pelenų naudojimo galimybes keraminių dirbinių gamyboje. Keraminiai gaminiai parodè kur kas mažesnị sunkiụjų metalų išsiplovimą dèl atsiradusios skystosios fazès kiekio.

Dugno pelenų naudojimas lengvujų užpildų (keramzito) gamyboje plačiai išnagrinètas autorių (Bethanis et al., 2002; Cheeseman et al., 2003; Schabbach et al., 2011; Vichaphund et al., 2012) darbuose. Optimalios užpildų savybės buvo pasiektos esant $1000-1200{ }^{\circ} \mathrm{C}$ temperatūrai. Degimo temperatūra gali keistis priklausomai nuo dugno pelenų cheminès sudèties. Nepriklausomai nuo aukščiausios degimo temperatūros, dugno pelenai paprastai turi didelị skystos fazès kiekị, todèl pagrindiniai gautų lengvųjų užpildų mineralai yra hematitas, kvarcas, gelenitas, kalcitas.

Iš dugno pelenų suformuotų granulių, naudojant greitą degimo 900$1080{ }^{\circ} \mathrm{C}$ temperatūroje režimą, galima gaminti lengvuosius užpildus (keramzitą) (Cheeseman et al., 2005). Išdegtų lengvụjų užpildų pagrindiniai mineralai yra diopsidas $\left(\mathrm{CaMgSi}_{2} \mathrm{O}_{6}\right)$, volostonitas $\left(\mathrm{CaSiO}_{3}\right)$ ir klinoenstatitas $\left(\mathrm{Mg}_{2} \mathrm{Si}_{2} \mathrm{O}_{6}\right)$, palyginti su žaliavų be dugno pelenų sudètimi, sumažeja kvarco ir hematito mineralų kiekis. $1080{ }^{\circ} \mathrm{C}$ temperatūroje išdegtų lengvųjų užpildų $\mathrm{Zn}$ ir Pb išsiplovimas yra ypač mažas. Degant $1020-1080{ }^{\circ} \mathrm{C}$ degimo temperatūroje, užpildų struktūroje atsiranda didelis stiklo fazès kiekis, uždaros sferinès formos 5$10 \mu \mathrm{m}$ poros, todèl autoriai mano, kad, norint užtikrinti dugno pelenų antrinị naudojimą, toks būdas yra efektyvus ir nereikalaujantis sudètingų technologinių procesų.

$85 \%$ dugno pelenų maišant su $15 \%$ ryžių lukštų ir išdegant $1200{ }^{\circ} \mathrm{C}$ temperatūroje, gaunami kitokie nei keramzitas, lengvieji ir poringieji užpildai, kurių išsiplovimo vertès neviršija 2003/33/ES reikalavimų, gniuždymo stipris siekia $0,9 \mathrm{MPa}$, tankis $-1,4 \mathrm{~g} / \mathrm{cm}^{3}$, susitraukimas $-25 \%$. Užpildai susideda iš dviejų sluoksnių, išorinis sluoksnis yra tankesnis bei stipresnis, vidinis sluoksnis yra gana poringas (1.4 pav.) (Giro-Paloma et al., 2017).

Autorius (Lin, 2006) mano, kad $40 \%$ dugno pelenų galima naudoti keraminiu dirbinių gamyboje, kai degimo temperatūra siekia $800-1000{ }^{\circ} \mathrm{C}$ ir išlaikymas aukščiausioje temperatūroje trunka 6 val. Dugno pelenai mažina mūro gaminių susitraukimą, didina tankį, išdegant $800^{\circ} \mathrm{C}$ ir $900{ }^{\circ} \mathrm{C}$ temperatūroje padidina gniuždymo stiprị, tačiau išdegant $1000{ }^{\circ} \mathrm{C}$ temperatūroje gniuždymo stipris mažèja. Dugno pelenai keičia keraminès šukès mineraloginę sudètị, be ịprastinių mineralų (kvarco, hematito, albito-anortito) fiksuojamas diopsido $\mathrm{Ca}(\mathrm{MgAl})(\mathrm{SiAl})_{2} \mathrm{O}_{6}$ mineralo atsiradimas. 


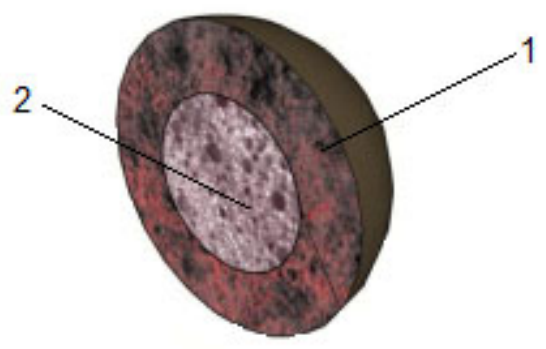

1.4 pav. Poringo užpildo, naudojant $85 \%$ dugno pelenų, dalelès struktūra (Giro-Paloma et al., 2017): 1 - išorinis užpildo sluoksnis; 2 - vidinis užpildo sluoksnis

Fig. 1.4. Investigation of the particle structure of a porous filler using $85 \%$ bottom ash (Giro-Paloma et al., 2017): 1 - outer filler layer; 2 - inner filler layer

Mokslininkai ịrodè (Lin et al., 2006), kad tokios sunkiai utilizuojamos atliekos, kaip vandens valymo dumblas ir KDA dugno pelenai, gali būti naudojamos kaip pagrindinès žaliavos keraminių mūro gaminių gamyboje. I formavimo mases įdejjus $25 \%$ dugno pelenų ir išdegant jas $1150{ }^{\circ} \mathrm{C}$ temperatūroje, gaminių įmirkis neviršija 2,78 \%, gniuždymo stipris nemažesnis nei $20 \mathrm{MPa}$. Atlikus struktūros tyrimus pastebètos atsitiktinès poringos ertmès, kurios, autorių nuomone, galèjo susidaryti dèl dugno pelenuose esančių organinių likučių bei kalcio junginių.

Andreola et al. (2005), gamindami degtus molio gaminius, naudojo 2,5-20\% dugno pelenų. Jie nustaté, kad $20 \%$ dugno pelenų gaminių įmirki padidino nuo $16 \%$ iki $26 \%$. Vandens įmirkio didejimas siejamas su papildomų porų susidarymu išdegant organiniams priedams, buvusiems dugno pelenuose. İdejus dugno pelenų pastebètas sumažejęs formavimo masès plastiškumas, todèl papildomai reikejjo $8 \%$ vandens. Taip pat ant bandinių paviršių atsirado išsūdų, kurios, mokslininkų manymu, galejjo susidaryti dẻl tirpių druskų, buvusių dugno pelenuose.

Schabbach et al. (2012) nustatè, kad dugno pelenų frakcijos dydis lemia keraminių gaminių savybes. İdedant $0-2 \mathrm{~mm}$ frakcijos dugno pelenų, keraminių gaminių, išdegtų $1100{ }^{\circ} \mathrm{C}$ temperatūroje, vandens įmirkis vidutiniškai mažesnis $6 \%$, lyginant su keraminių gaminių, kuriuose naudoti 2-8 mm frakcijos dugno pelenai. İrodyta, kad, ịdedant stambesnès frakcijos dugno pelenų, gaminio poros siekia 24-60 $\mu \mathrm{m}$, o įdedant smulkesnès frakcijos pelenų $(0-2 \mathrm{~mm})$ porų dydis siekia $7-$ $20 \mu \mathrm{m}$.

Taurino et al. (2017b) nustaté, kad ị molio (45\%) ir dugno pelenų (50\%), apdorotų $600{ }^{\circ} \mathrm{C}$ temperatūroje, išlaikant aukščiausioje temperatūroje 2 val., formavimo masę papildomai įdedant $5 \%$ fliusuojančio priedo $\mathrm{Na}_{2} \mathrm{CO}_{3}$, vyksta intensyvesnis kristalizacijos procesas, sumažeja sukepimo temperatūra, atsiranda didesnis skystosios fazès kiekis, dèl to mažèja atvirasis gaminių poringumas, 
susitraukimas po degimo, o visų gautų gaminių gniuždymo stipris yra didesnis kaip $20 \mathrm{MPa}$.

Keraminiu dirbinių gamyboje naudojant 20-40 \% KDA dugno pelenų, gaminių tankis siekia $1669-2007 \mathrm{~kg} / \mathrm{m}^{3}$, bendras atvirasis poringumas $-27,9-39,9 \%$, smarkiai sumažejja keraminių gaminių susitraukimas (Belmonte et al., 2018). 5$10 \% \mathrm{KDA}$ dugno pelenų galima naudoti ir porceliano gamyboje, kuris teigiamai veikia vykstančius kristalizacijos procesus, $20^{\circ} \mathrm{C}$ sumažina aukščiausią degimo temperatūrą (iki $1120^{\circ} \mathrm{C}$ temperatūros). Tokia gana aukšta degimo temperatūra sumažina sunkiụjų metalų išsiplovimo galimybes (Rambaldi et al., 2010).

Nustatyta, kad dviejų skirtingų frakcijų (0-2 $\mathrm{mm}$ ir 2-8 $\mathrm{mm}) 60 \%$ dugno pelenų ir $40 \%$ ugniai atsparaus molio mišinị galima naudoti keraminių plytelių gamyboje. İdejjus smulkesnę dugno pelenų frakciją, padidèja keraminių plytelių lenkimo stipris $(4,8 \mathrm{MPa}$ ir 4,2 MPa), Jungo modulis (49 GPa ir $45 \mathrm{GPa}$ ), tankis $\left(2,78 \mathrm{~g} / \mathrm{cm}^{3}\right.$ ir $\left.2,49 \mathrm{~g} / \mathrm{cm}^{3}\right)$, taip pat buvo įvertintas sunkiųų metalų išsiplovimas pagal EN-12457-2 standarto reikalavimus. Gauti rezultatai parodè, kad sunkiuju metalų $(\mathrm{Cu}, \mathrm{Zn}, \mathrm{Ni}, \mathrm{As}, \mathrm{Cd}, \mathrm{Cr}, \mathrm{Pb}$ ir kt.) išsiplovimas ypač mažas (Schabbach et al., 2012).

Nors sunkiujų metalų kiekis dugno pelenuose, palyginti su lakiaisiais pelenais, būna nedidelis, tačiau jų buvimas gali būti lemiamas kalbant apie dugno pelenų naudojimą. Mineraloginę dugno pelenų sudètį, akcentuojant sunkiujų metalų fazes, išnagrinèję mokslininkai (Wei et al., 2011) nustatè, kad šlaką sudaro silikato pagrindo stiklo fazè (48-54 \%) ir mineralinè fazè, įskaitant špinelì, pseudovolostanitą ir metalinius junginius (Fe-P, Fe-S, Fe-Cu, $\mathrm{Cu}-\mathrm{Sn}, \mathrm{Cu}-\mathrm{Zn}, \mathrm{Cu}-\mathrm{S}$ ir $\mathrm{Cu}-$ $\mathrm{Pb}$ ), kurie susidarè išsilydant pradiniams produktams. Sunkiųjų metalų junginiai, įterpti ị stiklo matricą, atlieka svarbų vaidmenį kalbant apie sunkiųjų metalų išsiplovimą.

Keraminių šukių gamyboje dugno pelenais galima visiškai pakeisti natūralias žaliavas, tokias kaip smèlis ar lauko špatai. Tokiuose gaminiuose identifikuojama $\mathrm{SiO}_{2}-\mathrm{Al}_{2} \mathrm{O}_{3}-\mathrm{CaO}-\mathrm{Fe}_{2} \mathrm{O}_{3}$ sistema, rentgenogramose paprastai identifikuojamos kvarco, anortito, gelenito ir hematito mineralu smailès (Schabbach et al., 2012). Bethanis et al. (2002), Keppert et al. (2012) nurodo, kad išdegtame gaminyje taip pat dažnai identifikuojami pageidaujami keramineje šukeje albito $\left(\mathrm{NaAlSi}_{3} \mathrm{O}_{8}\right)$ mineralai.

Cao et al. (2019) naudojo komunalinių atliekų dugno pelenus lengvujų užpildų (keramzito) gamyboje. Nustatyta, kad pagrindiniai dugno pelenų oksidai $\mathrm{SiO}_{2}, \mathrm{Al}_{2} \mathrm{O}_{3}$ ir $\mathrm{CaO}$ veikia gaminių kokybę ir daro įtaką struktūros formavimosi ypatumams. Nuo $25 \%$ iki $40 \%$ padidèjęs $\mathrm{SiO}_{2}$ formavimo masèje kiekis daro ịtaką struktūrai, o užpildų gniuždymo stipris padidejja nuo 0,5 iki 6,18 MPa, tankis - nuo 755 iki $1268 \mathrm{~kg} / \mathrm{m}^{3}$, vandens įmirkis mažèja nuo 50 iki $14 \%$. Mažesnio stiprumo poringos struktūros užpildai (daugiau atviru porų) buvo gauti įdejus ị formavimo mases $20 \%$ dugno pelenų. Stiprumas mažesnis, nes sumažèjęs $\mathrm{Al}_{2} \mathrm{O}_{3}$ 
kiekis slopina kristalizacijos procesus. Formavimo masėse padidejus $\mathrm{CaO}$ kiekiui nuo $21 \%$ iki $22 \%$, gniuždymo stipris sumažèjo nuo 8,82 iki 2,02 MPa, tankis nuo $1300 \mathrm{iki} 862 \mathrm{~kg} / \mathrm{m}^{3}$. Reguliuojant formavimo masejje komunalinių atliekų dugno pelenų kieki, galima gauti aukštos kokybės užpildus ir tinkamai utilizuoti tokio tipo atliekas.

Atliekant keraminių šukių su komunalinių deginimo atliekų dugno pelenais DTA tyrimus, nustatyta, kad didesnis šių keraminių šukių svorio sumažejimas gali būti susijęs su sulfatų skilimu. Nustatyti efektai patvirtina tiek organinių medžiagų, tiek karbonatų, esančių dugno pelenų sudètyje, skilimą degant, o tai lemia struktūros pasikeitimus ir porų formavimąsi. Nustatyta, kad galima gauti keraminius gaminius, išdegtus $1000{ }^{\circ} \mathrm{C}$ temperatūroje, ịdedant $20 \%$ komunalinių atliekų dugno pelenų. Tokie gaminiai pasižymi tradicinès keraminès šukès (t. y. be priedo) mechaninėmis savybėmis. Didesnis dugno pelenų kiekis padidina keraminių bandinių vandens įmirkị. Autoriai rekomenduoja keraminių dirbinių gamyboje naudoti iki $20 \%$ komunalinių atliekų dugno pelenų kiekį (Eliche-Quesada et al., 2017).

\subsubsection{Lakiujų pelenų poveikis degtų statybinių keraminių šukių struktūrai, savybėms ir toksiškumui}

Po komunalinių atliekų deginimo susidariusių lakiujų pelenų naudojimas statybinejje keramikoje yra ypač aktualus, norint aukštoje temperatūroje surišti arba imobilizuoti į netirpius junginius sunkiuosius metalus, kurių gausu lakiuosiuose pelenuose. Aukštoje temperatūroje $\mathrm{Pb}$ ir Zn metalai tarsi „kapsuliuojami“ keraminèse šukèse, dèl to labai mažeja jų išsiplovimo vertès (Arsenovic et al., 2012, 2015). Haiying et al. (2011), Yang et al. (2009), Lin et al. (2006) teigia, kad komunalinių deginimo atliekų lakiujų pelenų pagrindinių sunkiųjų metalų $(\mathrm{Cd}, \mathrm{Pb}, \mathrm{Zn}, \mathrm{Hg})$ išsiplovimas smarkiai sumažeja, nes aukštose temperatūrose jie užblokuojami skystoje fazeje.

Prieš naudojimą statybinès keramikos gamyboje lakieji pelenai gali būti papildomai apdorojami vandeniu, dèl to juose sumažeja $\mathrm{Pb}, \mathrm{Zn}, \mathrm{Cu}$ elementų kiekiai (Wang et al., 2016), taip pat chloridų kiekis (Wu et al., 2015), kuris gali neigiamai veikti keraminių gaminių kokybę. Taip pat lakieji pelenai gali būti ne tik apdorojami vandeniu, bet papildomai atliekamas jų elektrodialitinis valymas (Belmonte et al., 2018).

Keraminiai bandiniai su vandeniu apdorotais lakiaisiais pelenais, palyginti su keraminiais mūro gaminiais, išdegtais $1000{ }^{\circ} \mathrm{C}$ temperatūroje, išlaikant aukščiausioje degimo temperatūroje 6 val., turi didesni poringumą, didesnị tirpių druskų kiekị, mažesnị gniuždymo stiprị. Keraminių plytų su vandeniu apdorotais lakiaisiais pelenais, palyginus su vandeniu neapdorotais lakiaisiais pelenais, fizikinès ir 
mechaninès savybės yra geresnès. Siūloma ị formavimo mases įdèti iki $5 \%$ vandeniu apdorotų lakiųų pelenų. Tokių gaminių tankis siekia $1,63 \mathrm{~g} / \mathrm{cm}^{3}$, poringumas $-41 \%$, vandens įmirkis $-25,5 \%$, gniuždymo stipris $-8 \mathrm{MPa}$. Sunkiujų metalų išsiplovimas neviršija leidžiamujjų ribų (Wan, 2017).

Jordan et al. (2015) siūlo gaminti keraminius gaminius įdèjus 1-10 \% lakiųjų pelenų ir 15-35\% marmuro atliekų, išdegant gaminius $975-1050{ }^{\circ} \mathrm{C}$ temperatūroje. Nustatyta, kad didejant lakiujų pelenų kiekiui lenkimo stipris mažèja, vandens įmirkis dideja.

Keraminių dirbinių gamyboje naudojant 20-40 \% lakiųų pelenų kieki, gaminiu tankis siekia $1313-1578 \mathrm{~kg} / \mathrm{m}^{3}$, bendras atvirasis poringumas $-42,1-51 \%$. Tačiau sunkiụų metalų išsiplovimo tyrimai parode, kad išsiplovimas iš keraminių gaminių yra didelis ir neatitinka galiojančių normatyvinių dokumentų (Belmonte et al., 2018).

Teigiama (Deng et al., 2018), kad 0-25\% lakiųjų pelenų kiekis keraminių plytelių susitraukimą sumažina nuo $9 \%$ (kontrolinis bandinys) iki 1,2\%. Mikrostruktūroje dažnai fiksuojamos didelès dalelès, kurias sudaro $\mathrm{O}, \mathrm{Si}, \mathrm{Ca}, \mathrm{Al}$ ir $\mathrm{C}$, o tai ịrodo, kad šių dalelių cheminiai komponentai yra karbonatai ir aliumosilikatai. Smulkiosios dalelès daugiausia yra metaliniai elementai - Fe, Ti, $\mathrm{Na}$ ir kt.

Garsia-Ubague et al. (2007) teigia, kad ị keraminius bandinius reikètu įdèti 1-5\% lakiujų pelenų, kad būtų užtikrintos geros fizikinès ir mechaninès gaminių savybės. Taip pat nurodoma, kad iš tokių keraminių šukių nustatytos mažiausios sunkiụjų metalų (arseno, nikelio, chromo, švino ir kadmio) išsiplovimo vertès.

Remiantis pateikta literatūros analize (1.4 lentelè) nustatyta, kad lakiuosiuose pelenuose yra gana dideli chloridų kiekiai. Chloridai gali reaguoti su keraminèje šukeje esančiais $\mathrm{SiO}_{2}, \quad \mathrm{Al}_{2} \mathrm{O}_{3} \quad$ ir sudaryti ịvairius junginius $\left(\mathrm{CaCl}_{2}+\mathrm{H}_{2} \mathrm{O}+\mathrm{SiO}_{2} \rightarrow \mathrm{CaSiO}_{3}+2 \mathrm{HCl}\right.$, $\mathrm{CaCl}_{2}+\mathrm{H}_{2} \mathrm{O}+\mathrm{Al}_{2} \mathrm{O}_{3} \rightarrow \mathrm{CaAl}_{2} \mathrm{O}_{4}+2 \mathrm{HCl}$ ) (Nowak et al., 2013; Fraissler et al., 2009).

Nowak etal. (2013) pateikia lakiụjų pelenų mikrostruktūros schemą (1.5 pav.), nurodydami, kad sunkieji metalai, esantys lakiuosiuose pelenuose, gali būti ant dalelių paviršiaus, taip pat dalelių viduje, o tarp dalelių pasiskirsto chloridų junginiai. Kadmis $(\mathrm{Cd})$ dažniausiai randamas lakiụjų dalelių viršutiniame sluoksnyje, varis $(\mathrm{Cu})$ - dalelių viduje ir/arba porose. Teigiama, kad vario reakcija su aliuminio oksidais gali sumažinti jo išsiplovimo mastą $\left(\mathrm{CuO}+\mathrm{Al}_{2} \mathrm{O}_{3} \rightarrow \mathrm{CuAl}_{2} \mathrm{O}_{4}\right)$. Mažesnè švino $(\mathrm{Pb})$ išsiplovimo iš degtu gaminių tikimybe yra tada, kai jis sureaguoja su silikatais. Cinkas (Zn), panašiai kaip ir kadmis, yra ant dalelių paviršiaus, todèl gali sureaguoti su aliuminio bei silicio oksidu $\left(\mathrm{ZnO}+\mathrm{Al}_{2} \mathrm{O}_{3} \rightarrow \mathrm{ZnAl}_{2} \mathrm{O}_{4}, \mathrm{ZnO}+\mathrm{SiO}_{2} \rightarrow \mathrm{ZnSiO}_{3}\right.$ ) (Nowak et al., 2013). Taip pat teigiama, kad chromas $(\mathrm{Cr})$ gali reaguoti su kalcio oksidu ir sudaryti kalcio chromatą $\left(2 \mathrm{Cr}_{2} \mathrm{O}_{3}+4 \mathrm{CaO}+3 \mathrm{O}_{2} \rightarrow 4 \mathrm{CaCrO}_{4}\right)$ (Kirk et al., 2002). 


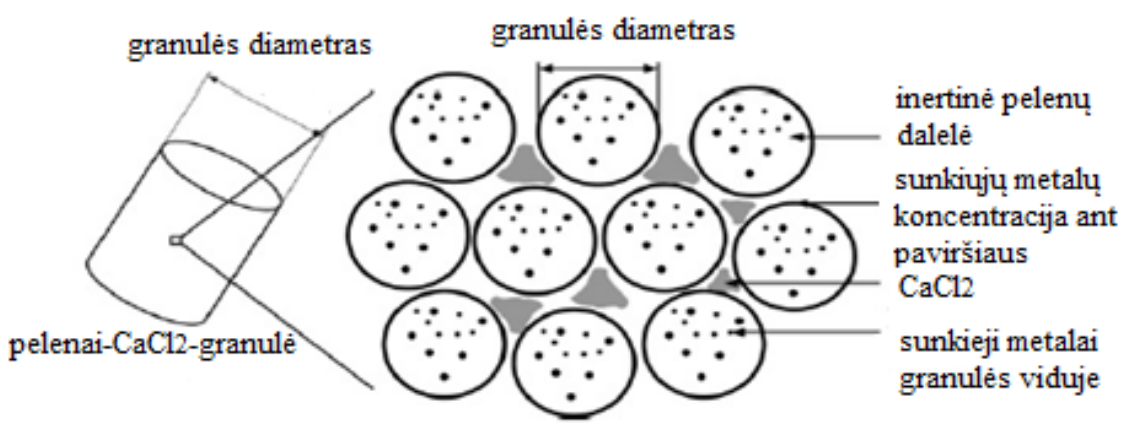

1.5 pav. Lakiųjų pelenų- $\mathrm{CaCl}_{2}$-granulių mikrostruktūra (Nowak et al., 2013)

Fig. 1.5. Microstructure of ash- $\mathrm{CaCl}_{2}-$ pellet (Nowak et al., 2013)

Lakiųjų pelenų rentgenografiniai tyrimai dažniausiai identifikuoja kalcio aliuminato, halito ir silvinito mineralus. Lakiụjų pelenų mikrostruktūra yra gana sudètinga, amorfinè ir heterogeninè. Rentgenografiniai tyrimai negali aptikti sunkiụjų metalu jonų, nes jie yra sujungti i junginius arba amorfiniai.

Mao et al. (2016), Tang et al. (2010, 2014), Lu \& Shih $(2012,2015)$ nustate, kad atliekos, turinčios didelị kiekị sunkiưų metalų, gali būti imobilizuojamos ị špinelio struktūrą $\left(\mathrm{NiAl}_{2} \mathrm{O}_{4}, \mathrm{ZnAl}_{2} \mathrm{O}_{4}, \mathrm{CuAl}_{2} \mathrm{O}_{4}\right.$ ir t. t). Špinelio struktūra yra gan atspari rūgštims ir neleidžia iš keraminès šukès išsiplauti sunkiesiems metalams. Kiti autoriai tvirtina, kad sunkieji metalai gali būti stabilizuojami keraminèse šukèse stiklo fazeje (Levitskii et al., 2013; Celary \& Sobik-Szołtysek, 2014).

Nustatyta (Mao et al., 2019), kad atliekinis priedas, turintis sunkiujų metalų, sumažina mineralo albito intensyvumą (kiekị) degtame gaminyje, o tai neigiamai veikia gaminių, išdegtų $950{ }^{\circ} \mathrm{C}$ temperatūroje, išlaikant aukščiausioje degimo temperatūroje 1-6 val., stiprumines savybes. $5 \%$ priedas keraminių gaminių stiprumą gniuždant sumažina nuo $16 \mathrm{MPa}$ (kontrolinis gaminys) iki $13 \mathrm{MPa}$, o vandens įmirkị padidina nuo $6,5 \%$ iki $7,3 \%$.

Sunkieji metalai gali būti stabilizuojami silikatų kristalinèje struktūroje esant aukštai keraminių gaminių degimo temperatūrai. Tačiau keraminių dirbinių technologijoje (900-1000 ${ }^{\circ} \mathrm{C}$ temperatūroje) atsiranda problema dèl sulfatų stabilizavimo, nes yra tikimybè, kad gaminio paviršiuje gali atsirasti išsūdų, kurios daro neigiamą įtaką estetinei gaminio kokybei. Dẻl šios priežasties autoriai rekomenduoja ị formavimo mases įdèti ne daugiau kaip $1 \%$ pelenų (Dondi et al., 2002).

Keraminèse šukèse su lakiaisiais pelenais degimo metu gali susidaryti sulfatų, kurių stabilumas priklauso nuo maksimalios degimo temperatūros. $\mathrm{Na}^{+}$, $\mathrm{K}^{+}$ir $\mathrm{Mg}^{2+}$ sulfatai gali suirti deginant aukštesneje nei $950^{\circ} \mathrm{C}$ temperatūroje, tačiau $\mathrm{Ca}^{2+}$ sulfatai gali išlikti stabilūs net $1050-1200{ }^{\circ} \mathrm{C}$ temperatūroje. Tai gali 
pabloginti estetinę gaminių kokybę (Brocken \& Nijland, 2004) ir taip apriboti lakiujų pelenų naudojimą.

Haiying et al. (2011) taip pat akcentuoja neigiamą poveiki gaminių kokybei, jei lakiuosiuose pelenuose yra 8-11\% ịvairių druskų, labiausiai chloridų. Jei formavimo masèje yra $25 \%$ lakiųų pelenų, tai išdegus ją $900-1000{ }^{\circ} \mathrm{C}$ temperatūroje, gaminių paviršiuje gali susidaryti išsūdų, todèl autoriai rekomenduoja tokią formavimo mišinio sudètị: $20 \%$ lakiujų pelenų, $60 \%$ molio, $10 \%$ lauko špatų ir $10 \%$ smèlio. Tokių gaminių, išdegtų $950{ }^{\circ} \mathrm{C}$ temperatūroje, vandens įmirkis mažesnis nei $11 \%$, gniuždymo stipris - $16 \mathrm{MPa}$, susitraukimas - 0,19\%, o sunkiuju metalų išsiplovimas atitinka normatyvinių dokumentų ribines vertes.

$\mathrm{Na}_{2} \mathrm{SO}_{4}$ ir $\mathrm{MgSO}_{4}$ lengvai prijungia ir termiškai apdorojant (maždaug $200{ }^{\circ} \mathrm{C}$ temperatūroje) atiduoda kristalizacinį vandenį. Keraminių šukių porose kristalohidratų susidarymas destrukciškai veikia porų sieneles dèl kristalohidratų tūrio didejjimo ir susidariusio spaudimo porų sienelèms. Šie sulfatai linkę formuotis lokalizuotose vietose, o tai turi neigiamą įtaką gaminių paviršiaus kokybei ir mažina keraminių dirbinių ilgaamžiškumą. Halitas $(\mathrm{NaCl})$ pasiskirsto tolygiai po visą keraminę šukę, užpildydamas mažiausias poras, todèl jo poveikis gaminių paviršiaus kokybei ir ilgaamžiškumui yra daug mažesnis. Literatūroje randama nemažai duomenų apie sulfatų bei chloridų neigiamą poveikį degtų keraminių dirbinių kokybei (Rodriguez-Navarro \& Doehne, 1999), teigiama, kad natrio chloridas daro įtaką gipso tirpumui (Lubelli et al., 2004).

$\mathrm{CaSO}_{4} \cdot 2 \mathrm{H}_{2} \mathrm{O}$ mažai tirpus, lètai formuojasi gaminio paviršiuje, beveik nekeičia savo tūrio, todèl tokių išsūdų atsiradimas dažniausiai neigiamai veikia tik gaminio paviršiaus estetinę kokybę, bet nedaro įtakos gaminių struktūros suardymui, veikiant atmosferai (Вахрамова et al., 2000).

Dondi et al. (1999) nurodo, kad pradinių kristalinių ir amorfinių fazių susidarymui ịtakos turi $\mathrm{CaO}$ kiekis, kuris lemia kalcio-silikatų fazes (plagioklazų, piroksenų, volastanitų). Kalcio oksidas taip pat gali keisti mineralų polimorfinius virsmus ir turèti ịtakos skystos fazès susidarymui (Baccour et al., 2008).

Taip pat manoma, kad, norint visapusiškai ištirti gaminius su atliekomis, turi būti atlikti radiaciniai bandinių tyrimai (Hewamanna et al., 2001).

Eliche-Quesada et al. (2017) rekomenduoja keraminių dirbinių, išdegtu $1000{ }^{\circ} \mathrm{C}$ temperatūroje, gamyboje naudoti iki $10 \%$ lakiujų pelenų kiekị. Nustatyta, kad tokių gaminių šilumos laidumo koeficientas mažeja nuo $1,05 \mathrm{~W} / \mathrm{mK}$ iki $1,00 \mathrm{~W} / \mathrm{mK}$, susiformuoja didesnis porų kiekis, padidèja vandens įmirkis.

\subsubsection{Dugno ir lakiujju pelenụ paruošimo technologijos}

Deginant komunalines atliekas susidariusių dugno ir lakiujų pelenų sudètis ir kiekiai priklauso nuo pradinès žaliavų sudèties, naudojamos degimo technologijos bei suprojektuotos oro taršos kontrolès sistemos. 
Degant komunalinėms atliekoms susidaro gana didelis kiekis dugno pelenų, kurie prieš naudojimą statybos ar/ir kitų sričių pramonèje naudojamų medžiagų gamyboje turi būti tinkamai apdoroti. Neapdorotuose dugno pelenuose yra ịvairiu metalų, stiklo, porceliano, kitų nedegiụjų ir organinių medžiagų likučių (Izquierdo et al., 2002; Chimenos et al., 1999; Del Valle-Zermeno et al., 2014). Todèl po degimo gauti dugno pelenai dažniausiai trupinami, sijojami, atliekamas metalų, kuriuose yra geležies, ir metalų, kuriuose nèra geležies, separavimas, vėliau tam tikrą laiką vykdomas jų sendinimo procesas.

Gamyklose dugno pelenai gali būti apdorojami šlapiuoju arba sausuoju būdu. Apdorojimo būdas daro ịtaką dugno pelenuose esantiems metalams. Apdorojant juos šlapiuoju būdu, metalo dalelès būna padengtos silicio, kalcio oksidais, o naudojant sausajį apdorojimo būdą ant metalo dalelių tokio mineralinių medžiagų sluoksnio nebūna (Lamers, 2015).

Morf et al. (2013) nustatè, kad, apdorojant dugno pelenus sausuoju būdu, iš jų atskiriamų metalų, kuriuose yra geležies, kiekis padideja net iki $45 \%$, o kitu metalų, kuriuose nèra geležies, net iki $50 \%$. Kiti autoriai (Rem et al., 2004) ịrodè, kad šlapiuoju būdu apdorojamiems dugno pelenams, suskirstytiems ị skirtingas frakcijas, gali būti taikomos skirtingos metalų atskyrimo technologijos. Tokiu būdu iš dugno pelenų galima atskirti net iki $85 \%$ metalų, kuriuose nèra geležies (Bakker et al., 2007). Metalai gali būti separuojami iš karto po dugno pelenų gavimo arba po sendinimo proceso.

Dèl dugno pelenų trupinimo, sijojimo, metalų separavimo ir sendinimo trukmès kiekviena šalis turi savo patvirtintus normatyvinius dokumentus (1.6 lentelè) (ISWA, 2006; LR įsakymas Nr.D1-805). Pagal galiojančius normatyvinius dokumentus Lietuvoje šlako ir pelenų sendinimo trukmè turi būti ne mažesnè kaip 3 mėnesiai. Kaip matoma iš pateiktų duomenų, skirtingų šalių paruošimo technologijos šiek tiek skiriasi. Skirtumai išryškejja analizuojant sendinimo ir metalų, kuriuose nèra geležies separavimo, paruošimo technologinius etapus.

Sendinimo metu šlakas ir pelenai supilti ị krūvas laikomi atvirose aikštelèse. Jie nèra apsaugoti nuo tiesioginio atmosferos poveikio, dèl kurio, vykstant cheminėms reakcijoms, jie iš šarminès būsenos pereina ị neutralią (Sabbas et al., 2001). Taip pat sendinimo metu dugno pelenuose vykstant fizikinèms ir cheminėms reakcijoms, vyksta ir tam tikrų savybių „stabilizavimas“ (Rendek et al., 2006). Organinès medžiagos, esančios dugno pelenuose, susiskaido dèl metalų oksidų ir hidratų reakcijų su atmosferiniais krituliais bei anglies dioksidu, susiformuoja karbonatai, todèl mažèja iš dugno pelenų išplaunamų metalų kiekis (Piantone et al., 2004; Lamers, 2015; Arickx et al., 2006).

Kitų mokslininkų tyrimai taip pat patvirtina, kad šviežių dugno pelenų išlaikymo natūraliomis sąlygomis procesas daro įtaką biologinio skilimo, karbonizavimosi ir hidratacijos reakcijoms vykstančioms juose (Arickx et al., 2006; Dijkstra et al., 2006). Natūralus išlaikymas skatina reakciją tarp šarminès medžiagos 
ir atmosferinio $\mathrm{CO}_{2}$, o tai lemia karbonatų susidarymą, dažniausiai kalcito (Freyssinet et al., 2002; Wei et al., 2011). Papildomos hidratacijos reakcijos stabilizuoja dugno pelenų mineralines medžiagas, kurios turi toksinių savybių, o tai gali sumažinti toksinių medžiagų išsiplovimo vertes (Baciocchi et al., 2010; Cornelis et al., 2012; Wei et al., 2014).

Ivairių šalių dugno pelenų paruošimo technologiniai parametrai pateikti 1.6 lentelëje. Kaip matoma iš pateiktų duomenų, Lietuvoje prieš naudojant dugno pelenus statybos ar/ir medžiagų inžinerijos tikslams, jie privalo būti trupinami, sijojami, turi būti atliekamas metalų, kuriuose yra geležies, separavimas. Metalų, kuriuose nèra geležies, separavimas nėra privalomas. Dugno pelenai taip pat turi būti sendinami 3 mènesius.

1.6 lentelè. İvairių šalių dugno pelenų paruošimo technologiniai parametrai

Table 1.6. Technological parameters of bottom ash preparation in some countries

\begin{tabular}{|c|c|c|c|c|c|c|c|c|c|}
\hline $\begin{array}{l}\text { Dugno pelenų paruo- } \\
\text { simo technologiniai pa- } \\
\text { rametrai }\end{array}$ & $\begin{array}{l}: \frac{\pi}{7} \\
\frac{0}{2} \\
\frac{0}{0} \\
>\end{array}$ & 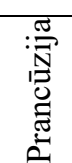 & $: \frac{\widetilde{\pi}}{\vec{\Xi}}$ & 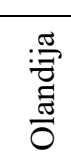 & $\stackrel{\widetilde{\Xi}}{\stackrel{0}{\Xi}}$ & $\frac{: \frac{\sigma}{D 0}}{0}$ & : & 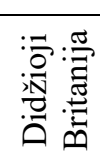 & 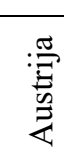 \\
\hline Trupinimas & $\mathrm{a}$ & $\mathrm{a}$ & $\mathrm{a}$ & $\mathrm{a}$ & $\mathrm{a}$ & $\mathrm{a}$ & $\mathrm{a}$ & $\mathrm{a}$ & $\mathrm{a}$ \\
\hline Sijojimas & $\mathrm{a}$ & $\mathrm{a}$ & $\mathrm{a}$ & $\mathrm{a}$ & $\mathrm{a}$ & $\mathrm{a}$ & $\mathrm{a}$ & $\mathrm{a}$ & $\mathrm{a}$ \\
\hline $\begin{array}{l}\text { Metalu, kuriuose yra } \\
\text { geležies, separavimas }\end{array}$ & $\mathrm{a}$ & $\mathrm{a}$ & $\mathrm{a}$ & $\mathrm{a}$ & $\mathrm{a}$ & $\mathrm{a}$ & $\mathrm{a}$ & $\mathrm{a}$ & $\mathrm{a}$ \\
\hline $\begin{array}{l}\text { Metalu, kuriuose nèra } \\
\text { geležies, separavimas }\end{array}$ & $\mathrm{a} / \mathrm{n}$ & $\mathrm{a} / \mathrm{n}$ & $\mathrm{a} / \mathrm{n}$ & $\mathrm{a}$ & $\mathrm{a} / \mathrm{n}$ & $\mathrm{a} / \mathrm{n}$ & $\mathrm{a} / \mathrm{n}$ & $\mathrm{a} / \mathrm{n}$ & $\mathrm{n}$ \\
\hline Sendinimas & $\mathrm{a}$ & $\mathrm{a}$ & $\mathrm{a}$ & $\mathrm{a}$ & $\mathrm{a}$ & $\mathrm{n}$ & $\mathrm{n}$ & $\mathrm{n}$ & $\mathrm{n}$ \\
\hline
\end{tabular}

$\mathrm{a}$ - atliekamas, $\mathrm{a} / \mathrm{n}$ - atliekamas arba neatliekamas, $\mathrm{n}$ - neatliekamas.

KDA lakiųjų pelenų paruošimo naudoti statybų inžinerijos tikslams bendros technologijos nèra. Kaip buvo minèta, dažniausiai vertinamas lakiųjų pelenų toksiškumas, t. y. sunkiujų metalų, chloridų ir sulfatų išsiplovimas, pagal Europos Parlamento ir Tarybos direktyvą 2003/33/EC, kurioje nustatomi atliekų prièmimo į sąvartynus kriterijai ir tvarka.

Kai kurių autoriu atliktuose moksliniuose darbuose siūloma lakiuosius pelenus prieš naudojimą papildomai apdoroti vandeniu (Wang et al., 2016; Wu et al., 2015) arba/ir atlikti elektrodialitinį lakiujų pelenų valymą (Belmonte et al., 2016). Vandeniu apdorotuose lakiuosiuose pelenuose sumažèja sunkiụjų metalų, tokių kaip Pb, Zn ir kt., ypač smulkiụjų frakcijų (Wang et al., 2016), chloridų bei sulfatų kiekis (Wu et al., 2015). Lakiujų pelenų apdorojimas vandeniu mažina juose esančių tirpiụjų druskų ir padidina lakiųjų pelenų naudojimo potencialą. Daugelis 
autorių nustate, kad chloridų kiekị galima sumažinti net iki 0,5 \% (Yang et al., 2014; Chimenos et al., 2005; Chen et al., 2016; Mulder, 1996).

Chen et al. (2012) teigia, kad LP esantys vandenyje tirpūs chloridai, tokie kaip kalio chloridas $(\mathrm{KCl})$, natrio chloridas $(\mathrm{NaCl})$, lengvai išplaunami apdorojant lakiuosius pelenus vandeniu, tačiau kalcio hidroksichloridas $(\mathrm{Ca}(\mathrm{OH}) \mathrm{Cl})$ kambario temperatūroje išplaunamas sunkiau. Chloridai taip pat pašalinami kaitinant lakiuosius pelenus. Autoriai nustate, kad, kaitinant lakiuosius pelenus $1050{ }^{\circ} \mathrm{C}$ temperatūroje, pelenai dèl ịvairių chloridų garavimo netenka $23,4 \%$ savo pradinio svorio, o chloridų pašalinimo efektyvumas siekia $83 \%$. Taip pat įrodyta, kad, kaitinant lakiuosius pelenus nuo $600{ }^{\circ} \mathrm{C}$ iki $1050{ }^{\circ} \mathrm{C}$ temperatūros, lakieji pelenai netenka nuo $1,75 \%$ iki $23,40 \%$ savo pradinio svorio, o chloridų koncentracija sumažèja atitinkamai nuo 3,61 \% iki 1,47\%.

\subsection{Pirmojo skyriaus išvados ir disertacijos uždavinių formulavimas}

1. Analizuojant literatūroje paskelbtus tyrimų rezultatus, galima teigti, kad kogeneracinèse jègainèse deginant komunalines atliekas vyksta sudètingi įvairių junginių transformacijos procesai, todèl antrinių degimo produktų, t. y. dugno ir lakiujuc pelenų, sudètis yra gana nepastovi. Dugno pelenuose, o ypač lakiuosiuose pelenuose yra pavojingujų medžiagų (sunkiujų metalų, chloridų, sulfatų), kurios gali apriboti atliekų naudojimo galimybes keraminių šukių gamyboje. Išanalizavus literatūroje pateiktus duomenis nustatyta, kad dugno ar lakieji pelenai lemia statybinès keramikos fizikines ir mechanines savybes, mineraloginę sudètį bei toksiškumą. Todèl svarbu ịvertinti minètų priedų poveikị struktūrai, termodinamiškai stabilių junginių formavimosi ypatumams, ilgaamžiškumui bei estetinei gaminiu kokybei.

2. Apibendrinus literatūros analizę, tikslinga atlikti dugno ir lakiụjų pelenų naudojimo keraminių gaminių, pagamintų iš vietinių lengvai lydžių molių galimybių tyrimus, patikslinti jų ịtaką eksploatacinèms savybèms, mineralogijai, struktūrai, ịvertinti įtaką ilgaamžiškumui, toksiškumui bei estetinei gaminių kokybei.

Užsibrèžtam darbo tikslui pasiekti buvo suformuluoti tokie uždaviniai:

1. Ištirti dugno ir lakiụjų pelenų poveikị keraminių šukių iš lengvai lydžių molių mineraloginei sudèčiai bei struktūros formavimosi ypatumams.

2. Nustatyti dugno ir lakiụjų pelenų ịtaką keraminių šukių fizikinėms ir mechaninėms savybėms bei ilgaamžiškumui, vertinat atsparumą šalčiui. 
3. Ivvertinti dugno ir lakiụjų pelenų, turinčių gana didelị kiekị sunkiujų metalų, chloridų bei sulfatų, aplinkosauginius naudojimo aspektus (sunkiujų metalų, chloridų, sulfatų išsiplovimą).

4. Pateikti rekomendacijas ribiniams komunalinių deginimo atliekų dugno, lakiųjų ir vandeniu apdorotų lakiųjų pelenų naudojimo keraminių šukių iš lengvai lydžių molių gamybai kiekiams, atsižvelgiant ị eksploatacines gaminių savybes, ịvertinant jų estetinę kokybę ir toksiškumą. 


\section{Medžiagos ir tyrimo metodai}

Šiame skyriuje aprašomos tyrimams naudotos žaliavos (molis, smėlis), jų savybès, formavimo masių paruošimo technologija, nagrinèjamų keraminių šukių technologiniai parametrai, apžvelgiami bandymo metodai, tyrimo metodikos ir bandymo iranga.

Skyriaus tematika kartu su bendraautoriais paskelbti šeši straipsniai (Voišnienė et al., 2018, 2019a, 2019b, 2020; Kizinievič et al., 2019; Voišnienė \& Kizinievič, 2018), skaityti pranešimai šešiose tarptautinèse konferencijose.

\subsection{Tyrimams naudotos medžiagos ir ju charakteristikos}

Eksperimentiniams bandymams naudotas lengvai besilydantis hidrožerutinis su kaolinito priemaiša Kuksos telkinio molis (Lietuva) bei liesinantis priedas. Komunalinių atliekų deginimo atliekos lakieji ir dugno pelenai buvo paimti iš termofikacinès jègainès UAB „Fortum Klaipèda“.

Cheminè sudètis gamtiniuose aliumosilikatuose tiesiogiai siejama su molio mineraline ir granuliometrine sudètimi. Molio cheminè ir granuliometrinè sudètis pateikta 2.1 ir 2.2 lentelèse.

I tyrimams naudoto molio cheminę sudètị įeina didelis (palyginti su kitais Lietuvos telkiniu moliais) $\mathrm{Al}_{2} \mathrm{O}_{3}+\mathrm{TiO}_{2}$ ir $\mathrm{Fe}_{2} \mathrm{O}_{3}$ kiekis, nedidelis kiekis 
$\mathrm{CaO}+\mathrm{MgO}$. Didelis $\mathrm{Fe}_{2} \mathrm{O}_{3}$ ir mažas $\mathrm{CaO}+\mathrm{MgO}$ kiekis lemia galutinio gaminio spalvą, o didelis organinių priemaišų kiekis $(9,54 \%)$ gali sukelti keraminių šukių pūtimąsi (Sadūnas 1997). Paprastai molyje esantys kalcio ir magnio oksidai $(\mathrm{CaO}+\mathrm{MgO})$ labai aktyvūs, reaguoja su kitais molio mineralų dehidratuotais mineralais, sudarydami tarpines aliuminatų, silikatų, gelenitų fazes, vèliau, keliant temperatūrą, termodinamiškai stabilias anortito, diopsido fazes. Didelio kiekio $\mathrm{Fe}^{3+}$ jonų buvimas Kuksos molyje svarbus dèl jo gebèjimo redukuotis iki $\mathrm{Fe}^{2+}$, o tai sudaro galimybę skatinti termodinamiškai stabilių fazių susidarymą, intensyvinti sukepimo reakcijas. Šarminių metalų buvimas $\left(\mathrm{Na}^{+}, \mathrm{K}^{+}\right)$yra pageidaujamas, nes skatina stiklingos fazès susidarymą žemesnèse temperatūrose. Nustatyta, kad karbonatinių priemaišų (dolomito, kalcito) kiekis molyje neviršija 0,14 \%, o tai rodo pakankamą, palyginti su kitais moliais, randamais Lietuvoje, molio švarumą (Sadūnas, 1997). Kuksos molis turi 84,5\% molingosios frakcijos (2.2 lentelè), kuri tiesiogiai susijusi su $\mathrm{Al}^{3+}$ kiekiu molyje: kuo daugiau molyje yra molinguju dalelių, tuo daugiau jame $\mathrm{Al}^{3+}$. Molio plastiškumo skaičius siekia 18,5, o tai leidžia priskirti šị molị prie vidutinio plastiškumo molio.

2.1 lentelè. Molio cheminè sudètis

Table 2.1. Chemical composition of the clay

\begin{tabular}{|l|l|l|l|l|l|l|l|l|}
\hline \multirow{2}{*}{$\begin{array}{l}\text { Ža- } \\
\text { liava }\end{array}$} & \multicolumn{6}{|l|}{ Chemine sudetis, \% } \\
\cline { 2 - 8 } & $\mathrm{SiO}_{2}$ & $\begin{array}{l}\mathrm{Al}_{2} \mathrm{O}_{3}+ \\
\mathrm{TiO}_{2}\end{array}$ & $\mathrm{Fe}_{2} \mathrm{O}_{3}$ & $\mathrm{CaO}$ & $\mathrm{MgO}$ & $\mathrm{Na}_{2} \mathrm{O}$ & $\mathrm{K}_{2} \mathrm{O}$ & $\begin{array}{l}\text { Kaitinimo } \\
\text { nuostoliai }\end{array}$ \\
\hline Molis & 51,43 & 20,54 & 7,44 & 4,26 & 3,07 & 0,42 & 3,3 & 9,54 \\
\hline
\end{tabular}

2.2 lentelè. Molio granuliometrinè sudètis

Table 2.2. The granulometric composition of the clay

\begin{tabular}{|l|l|l|l|l|l|}
\hline $\begin{array}{l}\text { Ža- } \\
\text { liava }\end{array}$ & $\begin{array}{l}>0,25 \mathrm{~mm} \\
\text { kiekis, \% }\end{array}$ & $\begin{array}{l}0,25-0,05 \\
\text { mm kiekis, \% }\end{array}$ & $\begin{array}{l}0,05-0,005 \\
\text { mm kiekis, } \\
\%\end{array}$ & $\begin{array}{l}0,005-0,001 \\
\text { mm kiekis, \% }\end{array}$ & $\begin{array}{l}<0,001 \mathrm{~mm} \\
\text { kiekis, \% }\end{array}$ \\
\hline Molis & 0,10 & 0,52 & 14,85 & 25,67 & 58,86 \\
\hline
\end{tabular}

2.1 paveiksle pateikta molio mikrostruktūra. Nustatyta, kad molio dalelès yra plokštelių formos, pasiskirsčiusios tolygiai, su kitomis dalelėmis kontaktuoja per plonus molio dalelių tiltelius. Plokštelių dydis nuo $0,5 \mu \mathrm{m}$ iki $1,5 \mu \mathrm{m}$, tarp plokštelių yra nuolaužų. 


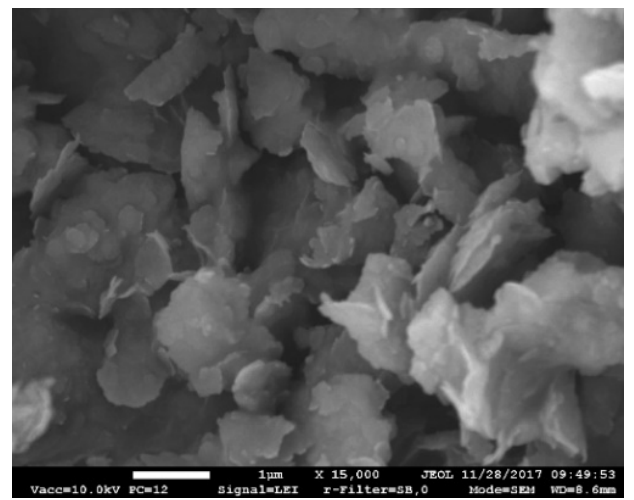

2.1 pav. Molio mikrostruktūra

Fig. 2.1. Microstructure of the clay

Atlikus molio mineraloginius tyrimus (2.2 pav.) nustatyta, kad molyje vyrauja šie mineralai: hidrožèrutis $\left(\mathrm{K}-\mathrm{Mg}-\mathrm{Fe}-\mathrm{Al}-\mathrm{Si}-\mathrm{O}-\mathrm{H}_{2} \mathrm{O}\right)$, kvarcas $\left(\mathrm{SiO}_{2}\right)$, lauko špatai $\left(\mathrm{Na}_{\mathrm{x}} \mathrm{Ca}_{1-\mathrm{x}} \mathrm{Al}_{2-\mathrm{x}} \mathrm{Si}_{2+\mathrm{x}} \mathrm{O}_{8}\right)$, kaolinitas $\left(\mathrm{Al}_{2} \mathrm{Si}_{2} \mathrm{O}_{5}(\mathrm{OH})_{4}\right)$.

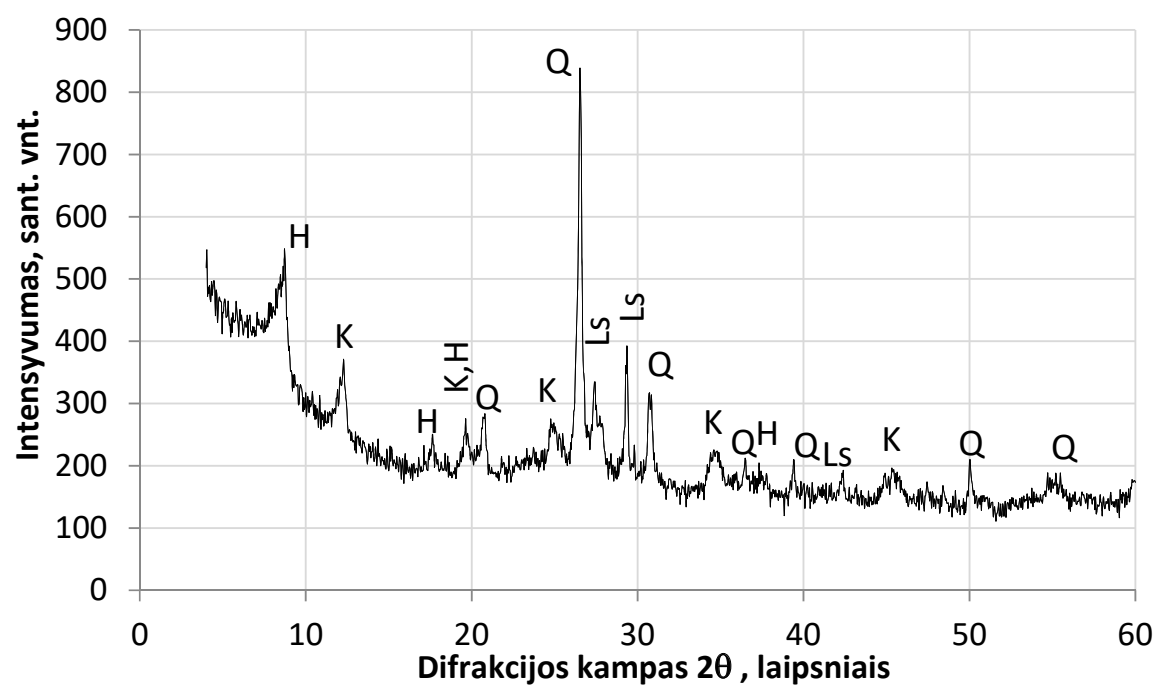

2.2 pav. Molio rentgenograma: $\mathrm{H}$ - hidrožėrutis;

$\mathrm{Q}$ - kvarcas; K - kaolinitas; Ls - lauko špatas

Fig. 2.2. The $\mathrm{X}$-ray diffraction pattern of clay: $\mathrm{H}$ - hydromica clay;

Q - quartz; K - kaolinite; Ls - feldspar 
Hidrožèrutis sudarytas iš trijų sluoksnių: vieną aliuminio oktaedrinị sluoksnị supa du silicio tetraedro sluoksniai, todè $\mathrm{Al}_{2} \mathrm{O}_{3}$ jame yra apie $20 \%$ (2.1 lentelè). Išdegto $1000^{\circ} \mathrm{C}$ temperatūroje molio rentgenografiniai tyrimai (2.3 pav.) parodè, kad pagrindiniai mineralai yra šie: anortitas $\left(\mathrm{CaAl}_{2} \mathrm{Si}_{2} \mathrm{O}_{8}\right)$, kvarcas $\left(\mathrm{SiO}_{2}\right)$, hematitas $\left(\mathrm{Fe}_{2} \mathrm{O}_{3}\right)$, špinelis $\left(\mathrm{MgAl}_{2} \mathrm{O}_{4}\right)$, diopsidas $\left(\mathrm{MgCaSi}_{2} \mathrm{O}_{6}\right)$.

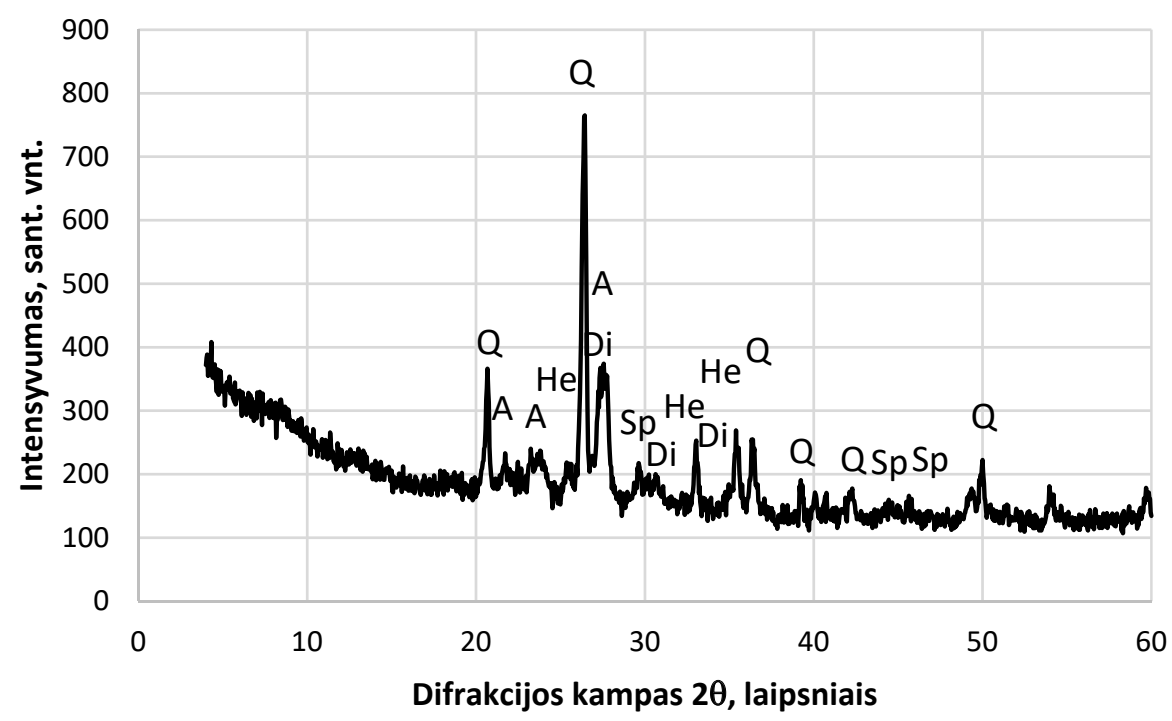

2.3 pav. Molio, išdegto $1000{ }^{\circ} \mathrm{C}$ temperatūroje, rentgenograma: A - anortitas; $\mathrm{Q}$ - kvarcas; He - hematitas; $\mathrm{Sp}$ - špinelis; $\mathrm{Di}$ - diopsidas

Fig. 2.3. The X-ray diffraction pattern of clay burned at $1000{ }^{\circ} \mathrm{C}$ temperature: $\mathrm{Q}$-quartz; A - anortite; He - hematite; $\mathrm{Sp}$ - spinel; $\mathrm{Di}$ - diopside

Molio diferencinès terminès analizès tyrimai (2.4 pav.) parodè, kad pirmasis endoterminis efektas vyksta $94{ }^{\circ} \mathrm{C}$ temperatūroje, masès nuostoliai siekia $1,7 \%$. Šis efektas susijęs su chemiškai nesurišto vandens pašalinimu, nes džiovinamas iki $105^{\circ} \mathrm{C}$ temperatūros molis netenka drègmès, bandinys traukiasi. Toliau vyksta staigus egzoterminis efektas, kurio maksimumas yra $\sim 320{ }^{\circ} \mathrm{C}$ temperatūroje, masès nuostoliai siekia $3,2 \%$. Šis efektas įvyksta išdegant organinėms medžiagoms, esančioms molyje. $506^{\circ} \mathrm{C}$ temperatūroje endoterminis efektas susijęs su tuo, kad atskyla chemiškai sujungtas vanduo, masès nuostoliai siekia 5,0 \%. Trečiasis endoterminis efektas įvyksta $735^{\circ} \mathrm{C}$ temperatūroje, masès nuostoliai $-10 \%$. Šio efekto metu skyla magnio ir kalcio karbonatai, susidaro molio kristalo gardelè. $880^{\circ} \mathrm{C}$ temperatūroje vyksta antrasis egzoterminis efektas, vyksta naujų kristalinių fazių susidarymas. 
Nustatyta, kad molio susitraukimas po džiovinimo siekia 9,8 \%. Išdegto $1000{ }^{\circ} \mathrm{C}$ temperatūroje molio susitraukimas siekia $12,5 \%$, tankis $-2,0 \mathrm{~g} / \mathrm{cm}^{3}$, vandens įmirkis $-8,5 \%$, gniuždymo stipris $-45 \mathrm{MPa}$.

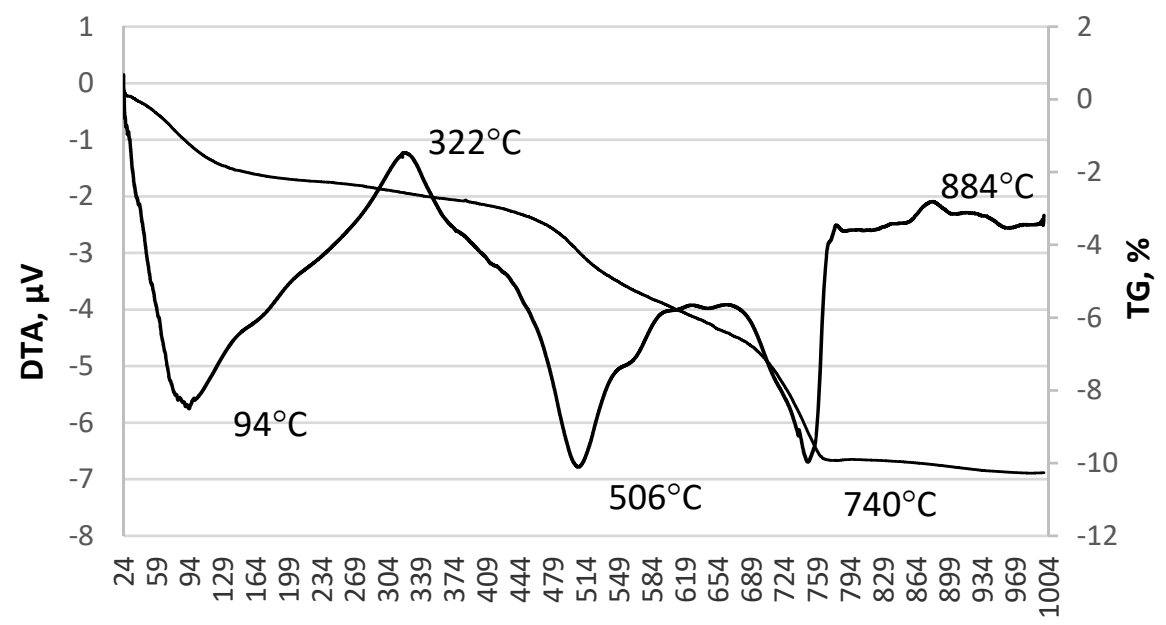

Temperatūra, ${ }^{\circ} \mathrm{C}$

2.4 pav. Molio termograma

Fig. 2.4. The thermogram of the clay

Norint mažinti molio džiūstamajji ir degamaji susitraukimą, formavimo masès plastiškumą ir jautrumą džiovinimui, buvo naudojamas liesinantis (smèlio) priedas. Smèlio cheminè sudètis yra tokia: $\mathrm{SiO}_{2}-84,5 \%, \mathrm{Fe}_{2} \mathrm{O}_{3}-0,98 \%, \mathrm{Al}_{2} \mathrm{O}_{3}-$ 4,56 \%, $\mathrm{CaO}-5,24 \%, \mathrm{MgO}-0,31 \%$, kaitinimo nuostoliai - 4,41\%; granuliometrinè smèlio sudètis: $2500 \mu \mathrm{m}-0 \% ; 1250 \mu \mathrm{m}-0,20 \%$; $1000 \mu \mathrm{m}-0,30 \%$; $800 \mu \mathrm{m}-1,50 \% ; 630 \mu \mathrm{m}-2,70 \% ; 400 \mu \mathrm{m}-7,50 \% ; 315 \mu \mathrm{m}-9,40 \%$; $200 \mu \mathrm{m}-34,40 \% ; 160 \mu \mathrm{m}-17,20 \% ; 100 \mu \mathrm{m}-17,80 \% ; 63 \mu \mathrm{m}-8,30 \%$; $50 \mu \mathrm{m}-0,65 \% ;<50 \mu \mathrm{m}$ (dugnas) - 0,05\%. Pagrindinis smèlio mineralas yra kvarcas, taip pat identifikuota ir lauko špatų.

\subsection{Formavimo masių sudètys ir technologiniai parametrai}

Darbe nagrinejjamas molis ir dugno pelenai buvo trupinami žiauniniu trupintuvu, džiovinami 24 val. $60 \pm 5^{\circ} \mathrm{C}$ temperatūroje, 24 val. $100 \pm 5^{\circ} \mathrm{C}$ temperatūroje, vèliau sijojami per $1,25 \mathrm{~mm}$ sietą. Smèlis buvo džiovinamas ir sijojamas per 
$1,25 \mathrm{~mm}$ sietą. Visos nagrinejjamos formavimo masès buvo ruošiamos vienodai, keičiant komunalinių deginimo atliekų - lakiụjų pelenų, vandeniu apdorotų lakiųų pelenų ir dugno pelenų - formavimo masėse kiekį. Vandens kiekis, reikalingas formavimui, svyravo $22-25 \%$.

Lakiųjų pelenų ir vandeniu apdorotų lakiụjų pelenų formavimo masėse kiekis keičiamas nuo 2,5 \% iki 7,5\%, dugno pelenų nuo 5,0 \% iki $15 \%$.

Lakieji pelenai buvo apdorojami vandeniu, remiantis mokslininkų atliktais tyrimais (Wan, 2017), kuriuose nurodoma, kad šiuo būdu apdorotų lakiụjų pelenų naudojimas teigiamai veikia statybinès keramikos gaminiu fizikines ir mechanines savybes, palyginus su vandeniu neapdorotais lakiaisiais pelenais, taip pat pelenuose sumažèja chloridų bei sunkiụjų metalų kiekiai (Wu et al., 2015; Wang et al., 2016), o tai teigiamai veikia gaminių kokybę.

Darbe nagrinejjamų formavimo masių sudètys pateiktos 2.3 lentelèje. Iš pateiktų formavimo masių suděčių buvo formuojami $70 \times 70 \times 70 \mathrm{~mm}, 50 \times 50 \times 50 \mathrm{~mm}$ ir $60 \times 30 \times 18 \mathrm{~mm}$ bandiniai.

2.3 lentelè. Formavimo masių sudètys (\% pagal masę)

Table 2.3. Compositions of the formation masses ( $\%$ of mass)

\begin{tabular}{|c|c|c|c|c|}
\hline \multirow{2}{*}{$\begin{array}{l}\text { Formavimo } \\
\text { masès }\end{array}$} & \multicolumn{4}{|c|}{ Žaliavos } \\
\hline & Molis & Smèlis & $\begin{array}{l}\text { Lakieji pelenai, } \\
\text { vandeniu apdoroti } \\
\text { lakieji pelenai* }\end{array}$ & $\begin{array}{l}\text { Dugno pele- } \\
\text { nai }\end{array}$ \\
\hline $\mathrm{C}$ & 100 & 0 & 0 & 0 \\
\hline CS & 90 & 10 & 0 & 0 \\
\hline FA 2,5 & 87,5 & 10 & 2,5 & 0 \\
\hline FA 5 & 85 & 10 & 5,0 & 0 \\
\hline FA 7,5 & 82,5 & 10 & 7,5 & 0 \\
\hline FAW 2,5 & 87,5 & 10 & $2,5^{*}$ & 0 \\
\hline FAW 5,0 & 85 & 10 & $5,0^{*}$ & 0 \\
\hline FAW 7,5 & 82,5 & 10 & $7,5^{*}$ & 0 \\
\hline BA 5 & 95 & 0 & 0 & 5,0 \\
\hline BA 10 & 90 & 0 & 0 & 10,0 \\
\hline BA 15 & 85 & 0 & 0 & 15,0 \\
\hline
\end{tabular}

Technologiniai formavimo masių parametrai pateikti 2.4 lenteleje (Atterbergo metodas (Atterberg, 1911; ASTM Standard D 4318:2005)). Nustatyta, kad 
įdedant didesnị dugno pelenų, lakiųjų pelenų arba vandeniu apdorotų lakiưjų pelenų kiekị i formavimo mases, vandens kiekis, reikalingas formavimo masėms užmaišyti, didèja, todèl didèja formavimo masių skysčio ir plastiškumo riba bei atitinkamai mažèja formavimo masių plastiškumo skaičius. Atterbergo ribos parodo plastiškų molio dalelių, esančių vandenyje, paruošiant formavimo mases, santykị. Formavimo masiu plastiškumo ir skysčio (takumo) ribos priklauso nuo molio ir naudojamų priedų mineraloginès sudèties bei molingưu dalelių kiekio mišinyje (Benson \&Trast, 1995).

2.4 lentelė. Technologiniai formavimo masių parametrai (Atterbergo metodas)

Table 2.4. Technological parameters of mass formation (Atterberg method)

\begin{tabular}{|l|l|l|l|}
\hline \multirow{2}{*}{ Formavimo masės } & \multicolumn{3}{|l|}{ Technologiniai parametrai } \\
\cline { 2 - 4 } & $\begin{array}{l}\text { skysčio (takumo) } \\
\text { riba, \% }\end{array}$ & plastiškumo riba, \% & $\begin{array}{l}\text { plastiškumo skai- } \\
\text { čius }\end{array}$ \\
\hline C & $35 \pm 0,3$ & $16,5 \pm 0,1$ & $18,5 \pm 0,2$ \\
\hline CS & $36,2 \pm 0,1$ & $18,2 \pm 0,2$ & $18,0 \pm 0,3$ \\
\hline FA 2,5 & $37,6 \pm 0,2$ & $20,5 \pm 0,2$ & $17,1 \pm 0,2$ \\
\hline FA 5 & $38,6 \pm 0,3$ & $22,6 \pm 0,3$ & $16,0 \pm 0,2$ \\
\hline FA 7,5 & $39,4 \pm 0,2$ & $23,9 \pm 0,2$ & $15,5 \pm 0,3$ \\
\hline FAW 2,5* & $36,8 \pm 0,2$ & $19,3 \pm 0,2$ & $17,5 \pm 0,1$ \\
\hline FAW 5* & $37,4 \pm 0,3$ & $20,6 \pm 0,3$ & $16,8 \pm 0,2$ \\
\hline FAW 7,5* & $38,1 \pm 0,1$ & $21,8 \pm 0,2$ & $16,3 \pm 0,1$ \\
\hline BA 5 & $37,2 \pm 0,2$ & $20,1 \pm 0,1$ & $17,1 \pm 0,1$ \\
\hline BA 10 & $37,8 \pm 0,3$ & $21,5 \pm 0,2$ & $16,3 \pm 0,2$ \\
\hline BA 15 & $39,2 \pm 0,1$ & $24,0 \pm 0,3$ & $15,2 \pm 0,2$ \\
\hline
\end{tabular}

Formavimo masių, įdedant lakiųų ar dugno pelenų, skysčio ir plastiškumo ribų padidejjimas rodo, kad formavimo masèse sumažèjo molingujų dalelių kiekis, o vandens kiekis reikalingas tinkamam užmaišymui didèja. Komunalinių atliekų lakieji ir dugno pelenai priskiriami neplastiškoms žaliavoms, o tai ịrodo plastiškumo skaičių mažèjimo tendencijas įdedant didesnị atliekų ị formavimo mases kiekị. Literatūroje (Benson \& Trast, 1995; Faria et al., 2012; Chao-Lung \& TrongPhuoc, 2015) taip pat teigiama, kad formavimo masių plastiškumo skaičius mažèja, didinat liesinančių, neplastiškų priedų kiekį. 
Pagal normatyvinị dokumentą (GOST 9169-75) formavimo masės pagal plastiškumo skaičiu , kai jis yra ne mažesnis nei 15, priskiriamos vidutinio plastiškumo formavimo masėms. Kaip teigia Panjaitan (2014), Andrade et al. (2011) ir remiantis ASTM D4318, formavimo masės su plastiškumo skaičiumi tarp 7 ir 17 taip pat priskiriamos prie vidutinio plastiškumo formavimo masių.

Pradinis suformuotų bandinių džiovinimo etapas buvo atliekamas natūraliomis laboratorinèmis sąlygomis 2 savaites $\left(18 \pm 5^{\circ} \mathrm{C}\right.$ temperatūroje). Vèliau bandiniai buvo džiovinami pagal parinktą režimą: pirmą parą $60 \pm 5{ }^{\circ} \mathrm{C}$ temperatūroje, antrą parą $105 \pm 5{ }^{\circ} \mathrm{C}$ temperatūroje.

Bandiniai buvo degami $1000{ }^{\circ} \mathrm{C}$ temperatūroje, išlaikant aukščiausioje degimo temperatūroje 1 val. Bendra bandinių degimo trukmé -21 val. Iki $1000{ }^{\circ} \mathrm{C}-$ temperatūros pakilimo sparta sudarè $50{ }^{\circ} \mathrm{C} /$ val. Bandinių degimo režimas parinktas pagal lengvai lydžių molių degimo režimo literatūrinę analizę (Sadūnas, 1997).

\subsection{Tyrimo metodai}

Medžiagų kokybinė fazinė sudèties analizè buvo atlikta DRON-7 rentgeno difraktometru. Rentgeno spinduliuotès $\mathrm{Cu} \mathrm{K} \alpha$ spektrui $(\lambda=0,1541837)$ gauti naudotas grafito monochromatorius. Fazès identifikuotos šifruojant rentgenogramas su EVA („Bruker AXS“) programine ịranga ir PDF-2, ICDD difrakcijos duomenų bazėmis. Kiekybiniai mineralu pokyčiai rentgenogramose buvo vertinami pagal mineralų difrakcinio maksimumo smailès aukštị.

Rentgeno struktūriniai tyrimai atlikti rentgeno spindulių difraktometru „SmatLab“ (gamintojas „Rigaku“) su 9 kW besisukančiu $\mathrm{Cu}$ (vario) anodu. Rentgenogramos užrašytos naudojant polikapiliarinę optiką teta/2teta (difrakcijos kampas) režimu.

Medžiagų cheminé sudètis nustatyta naudojant rentgeno fluorescencijos (XRF-WD) metodą su „ZSX Primus IV“" spektrometru („Rigaku Corp.“, Japonija, $\mathrm{Rh}$ anodas, ịtampa $4 \mathrm{kV}$ ). Tyrimui atlikti paruošti $37 \mathrm{~mm}$ skersmens $\sim 4 \mathrm{~mm}$ aukščio bandiniai (suslègti hidrauliniu presu $20 \mathrm{kN}$ jèga).

Medžiagų diferencinè terminė analizė buvo atliekama „Linseis STA PT$1600^{\prime \prime}$ prietaisu. Platinos tiglis su $60 \mathrm{mg}$ svorio bandiniu buvo kaitinamas oro aplinkoje iki $1000{ }^{\circ} \mathrm{C}$, temperatūros kèlimo greitis $10^{\circ} \mathrm{C} / \mathrm{min}$. Visų nagrinejjamų medžiagų smulkumas buvo parinktas vienodas, kad galima būtų maksimaliai ịvertinti kiekybinius smailių rodiklius.

Medžiagų mikrostruktūros tyrimams atlikti naudotas SEM JEOL JSM $7600 \mathrm{~F}$ skenuojančiosios elektroninès mikroskopijos prietaisas (elektroninès mikroskopijos parametrai: įtampa $-10 \mathrm{kV}$ ir $20 \mathrm{kV}$, atstumas iki bandinio paviršiaus $7-10 \mathrm{~mm})$. 
Analizuojant medžiagų granuliometrines sudètis, didesnių už $0,05 \mathrm{~mm}$ dalelių kiekiai buvo nustatomi plaunant per sietus, o smulkesnių kaip $0,05 \mathrm{~mm}$ dalelių kiekis nustatytas sedimentacijos būdu pagal skirtingą dalelių nusèdimo vandenyje greitị. Medžiagu granuliometrinè sudètis taip pat nustatyta lazeriniu granuliometru „Cilas 1090 LD“, kaip dispersinè terpé naudotas vanduo, kietujų medžiagu kiekis suspensijoje - 12-14\%.

Keraminès šukès gniuždymo stipris nustatytas pagal LST EN 7721:2011+A1:2015, neto sausasis tankis nustatytas pagal LST EN 772-13:2003, vandens įmirkis $(W$ ) pagal EN 772-21:2011, pradinè vandens įmirkio sparta - pagal LST EN 772-11:2011.

Bandinių ilgaamžiškumas buvo vertinamas tūrinio ir vienpusio šaldymo ir atšildymo būdais pagal LST 1985:2006 ir LST EN 772-22:2019. Bandinių ilgaamžiškumas gali būti vertinamas dviem (vienpusiu ir tūriniu šaldymo-atšildymo būdu) metodais. Tyrimai tiek vienpusiu, tiek tūriniu šaldymo-atšildymo metodais buvo atlikti todèl, kad kartais statybinès keramikos, naudojamos stipriai ardančioje aplinkoje, gaminiai pagal ịvairius konstrukcinius sprendimus negali būti apsaugoti nuo klimatinių sąlygų iš visų pusių. Vadinasi, realiomis eksploatacinemis sąlygomis gaminius veikia tūrinis šaldymo-atšildymo metodas. Taip pat žinoma, kad vienpusiu šaldymo-atšildymo būdu išbandytų gaminių, priskiriamų F2 klasei (stipriai ardanti aplinka, 100 ciklu), ilgaamžiškumas, naudojant gaminius realiomis eksploatacinemis sąlygomis, kartais būna labai prastas. Todèl daugelis autoriu (de Almeida, 2014; Kizinievič, 2008; Smith et al., 2016) mano, kad normatyviniuose dokumentuose nurodytas atsparumo šalčiui ciklų skaičius - 100, yra nepakankamas ir turi būti padidintas.

Sunkiujjų metalų kiekis eliuatuose (iš keraminių šukių) nustatytas atominès adsorbcijos spektrinès analizès metodu, naudojant spektrometrą „Buck Scientific 2010 VGP“ su oro-acetileno liepsna. Eliuatas paruoštas pagal LST EN 124572:2003 „Atliekų apibūdinimas. Išplovimas. Iš grūdètų atliekų išplautų medžiagu ir dumblo sudeties atitikties tyrimas. 2 dalis. Vienpakopis partijos (tyrinio) tyrimas, kai skysčio ir kietosios medžiagos santykis $10 \mathrm{l} / \mathrm{kg}$ ir dalelių dydis mažesnis kaip 4 mm (dydị mažinant arba nemažinant)" standarte nurodytą metodiką.

Medžiagų pH ir savitojo elektrinio laidumo tyrimams tirpalas buvo gaminamas naudojant $2 \mathrm{~g}$ tiriamosios medžiagos ir $100 \mathrm{~g}$ distiliuoto vandens. Tirpalas maišytas magnetine maišykle $45 \mathrm{~min}$., vèliau nufiltruotas per popierinį filtrą ir atlikti matavimai. Savitasis laidumas matuotas savitojo elektrinio laidumo matuokliu „Cond 315i“, naudojant elektrodą „Tetra Con 325“. Tirpalų šarmingumo tyrimai atlikti pH matuokliu „HANA HI 9321“.

Lakiųjų pelenų apdorojimas vandeniu buvo atliekamas santykiu 1:10 (lakieji pelenai: $\mathrm{H}_{2} \mathrm{O}$ dist.). Sumaišius 500 g lakiujjų pelenų su 51 distiliuoto vandens, jie buvo mirkomi ir maišomi 2 valandas. Pagamintas lakiujų pelenų tirpalas nufiltruotas per popierinį filtrą (Filtrai FILPAP, peleningumas - 0,5\% (KA $1 \mathrm{M}-$ 
$0,4 \%$ ). $80 \mathrm{~g} / \mathrm{m}^{2}$ ), ant filtro likę drègni lakieji pelenai nuimti ir džiovinti 48 valandas džiovinimo spintoje, kurioje palaikoma $105^{\circ} \mathrm{C}$ temperatūra. Vèliau pagal ankščiau aprašytą metodiką matuotas išplautų lakiujų pelenų pH ir savitasis elektrinis laidumas.

Dugno ir lakiujų pelenų sausoji liekana nustatyta - pagal DIN 38414-2:198511, ištirpusios organinès anglies kiekis - pagal EN 1484:2019-04, bendros organinès anglies kiekis - pagal ISO 10694:1995, chloridų, sulfatų, fluoridų, sieros kiekiai - pagal EN ISO 10304-1:2009. Sunkiujų metalų kiekis eliuatuose (iš dugno ir lakiujuc pelenų) nustatytas - pagal EN ISO 11885:2009-09 (E22).

Džiūstamasis ir degamasis susitraukimai nustatyti pagal ASTM C326-09 (2014). Technologiniai formavimo masių parametrai (2.4 lentelè) nustatyti pagal ASTM D 4318:2005.

Keraminių šukių struktūriniai rodikliai (atvirasis poringumas, bendrasis poringumas, sąlyginis porų ir kapiliarų sienelių storis, porų ir kapiliarų įsotinimo koeficientas) nustatyti pagal pateiktą (Sadūnas, 1997; Mačiulaitis, 1997; Hall \& Hoff, 2002) metodiką.

Keraminių šukių radioaktyvumo koncentracijai ịvertinti pagal standartą IEC 1452:1995 IEC „Radionuklidų gama spinduliuotès intensyvumo matavimas - germanio spektrometru kalibravimas ir naudojimas, gama spektrometru su koaksialiniu švaraus germanio detektoriumi“" buvo atlikti radiaciniai matavimai. Radionuklidų koncentracijos lygis, kuri leidžia ES ir Lietuvos normos palygintas atsižvelgiant ị HN 85:2011, Nr. V-890 normas. Po tyrimo keraminių šukių (po vienos keraminès šukès, trijų bandinių) radionuklidų savitųjų aktyvumų vidurkiai $\left(\mathrm{Bq} \cdot \mathrm{kg}^{-1}\right)$ pateikti su $95 \%$ pasikliautinaisiais intervalais.

Fizikinėms savybèms nustatyti buvo parinkti ir išbandyti ne mažiau kaip penki skirtingų (nurodyta anksčiau) matmenų bandiniai (imties dydis 15 bandinių). Mechaninėms savybėms nustatyti buvo parinkti ir išbandyti ne mažiau kaip penki $70 \times 70 \times 70 \mathrm{~mm}$ bandiniai (imties dydis 5 bandiniai). Skirtingais metodais ịvertinti keraminių šukių ilgaamžiškumą, kiekvienam jų buvo naudojami ne mažiau kaip penki $70 \times 70 \times 70 \mathrm{~mm}$ bandiniai (imties dydis 5 bandiniai). Sunkiujų metalų išsiplovimui, $\mathrm{pH}$ ir elektrinio laidumo rezultatų îvertinimui iš degtų keraminių šukių buvo naudojami ne mažiau kaip trys bandiniai (imties dydis 3 bandiniai).

Eksperimentiniais bandymais nustatant keraminių šukių charakteristikas, buvo stebimas gautų rezultatų išsibarstymas, kuris yra charakteristikų statistinès prigimties pasekmè. Skirtinguose vienos keraminès šukès atskiruose bandiniuose yra įvairūs mikro- skirtumų rinkiniai, dèl to kai kurių savybių reikšmės gali šiek tiek skirtis, t. y. atsirasti išskirtinių reikšmių. Todèl darbe buvo naudojamas statistinis eksperimentinių duomenų apdorojimas, leidžiantis pakankami tiksliai ịvertinti keraminių šukių charakteristikas, įvertinant gautų verčių išsibarstymą. 


\subsection{Antrojo skyriaus išvados}

1. Atlikus tyrimus nustatyta, kad disertacijoje tirtas molis yra lengvai lydus, jame yra didesnis $\mathrm{Al}_{2} \mathrm{O}_{3}+\mathrm{TiO}_{2}$ ir $\mathrm{Fe}_{2} \mathrm{O}_{3}$ kiekis (palyginus su kitais Lietuvos telkinių moliais), nedidelis $\mathrm{CaO}+\mathrm{MgO}$ kiekis. Molio susitraukimas po džiovinimo siekia $9,8 \%$, susitraukimas po degimo $1000{ }^{\circ} \mathrm{C}$ temperatūroje siekia $12,5 \%$, kaitinimo nuostoliai $-9,54 \%$, tankis $-2,0 \mathrm{~g} / \mathrm{cm}^{3}$, vandens įmirkis $-8,5 \%$, gniuždymo stipris $-45 \mathrm{MPa}$.

2. Siekiant ištirti keramines šukes naudojant po komunalinių atliekų deginimo susidarančius atliekinius produktus bei atsižvelgiant $i \mathfrak{i}$ literatūroje pateiktus rezultatus, buvo parinkti $2,5 \%, 5,0 \% 7,5 \%$ lakiujų pelenų ir vandeniu apdorotų lakiujų pelenų ir 5,0\%, 10,0\% 15,0\% dugno pelenų formavimo masèse kiekiai ir $1000{ }^{\circ} \mathrm{C}$ temperatūra, išlaikant aukščiausioje degimo temperatūroje 1 val., technologiniai parametrai.

3. Suformuluotiems disertacijos darbo uždaviniams spręsti suplanuotas eksperimentas suskirstytas ị etapus: 1 etapas - lakiujų pelenų ir vandeniu apdorotų lakiujų pelenų įtaka keraminių šukių mineraloginei sudèčiai, struktūrai, savybèms, toksiškumo, ilgaamžiškumui ịvertinimas; 2 etapas dugno pelenų įtaka keraminių šukių struktūrai, savybėms ir ilgaamžiškumui.

4. Normatyvinių dokumentų bei literatūros analizè rodo, kad keraminių mūro gaminių savybėms nustatyti dažniausiai naudojami standartiniai tyrimo metodai, taip pat gali būti naudojamos nestandartinès metodikos. Parinkti tyrimo metodai leidžia nustatyti degtų keraminių šukių fizikines ir mechanines savybes, struktūrinius rodiklius, ištirti gautų medžiagų makro- ir mikrostruktūrą, ịvertinti mineraloginius pokyčius bei ilgaamžiškumą, vertinant atsparumo šalčiui aspektu; ivvertinti ekologinius tokių atliekinių priedų naudojimo aspektus - ištirti sunkiųų metalų, chloridų ir sulfatų išsiplovimo iš keraminių šukių galimybes. 



\section{Komunalinių deginimo atliekų lakiụjų pelenų, dugno pelenų bei keraminių šukių struktūros, savybių ir ilgaamžiškumo tyrimai}

Šiame skyriuje pateikti komunalinių deginimo atliekų lakiųų ir dugno pelenų tyrimo rezultatai (3.1 poskyris). Pateikta keraminių šukių su lakiaisiais pelenais (3.2 poskyris) mineraloginè sudètis bei estetinès kokybès, termografinès analizès, toksiškumo, fizikinių ir mechaninių savybių, mikrostruktūros, ilgaamžiškumo tyrimų rezultatai. Tai pat pateikti keraminių šukių su dugno pelenais (3.3 poskyris) mineraloginès sudèties, termografinès analizès, toksiškumo, fizikinių ir mechaninių savybių, mikrostruktūros, ilgaamžiškumo tyrimo rezultatai. Atsižvelgiant ị gautus tyrimų rezultatus, pateiktos lakiųų ir dugno pelenų naudojimo statybinejje keramikoje rekomendacijos.

Skyriaus tematika kartu su bendraautoriais paskelbti septyni straipsniai (Voišnienè et al., 2018, 2019a, 2019b, 2019c, 2020; Kizinievič et al., 2019; Voišnienė \& Kizinievič, 2018), skaityti pranešimai septyniose konferencijose, paruoštas Lietuvos Respublikos patentas. 


\subsection{Lakiujų ir dugno pelenų tyrimai}

\subsubsection{Lakiųjų pelenų tyrimai}

Pradžioje tyrimams naudoti komunaliniu atliekų deginimo termofikacinėje jègainèje UAB „Fortum Klaipèda“ nuo 2017-01-09 iki 2017-07-05 susidarę lakieji pelenai. Lakiujų pelenų eliuatas paruoštas pagal EN 13657, tyrimų rezultatai pateikti 3.1 lentelëje. Kaip matoma iš pateiktų duomenų, skirtingų partijų ịvairių cheminių elementų vertès skiriasi. Literatūroje (žr. 1.4 lentelę), atlikus ịvairių autorių mokslinių publikacijų analizę, taip pat nurodyta, kad komunalinių atliekų lakiưjų pelenų cheminè sudètis nèra pastovi ir priklauso nuo daugelio parametrų, kurie analizuojami literatūros apžvalgoje.

Ištyrus skirtingų partijų lakiuosius pelenus, tolesniems tyrimams buvo atsitiktinai parinkti vienos partijos lakieji pelenai (žr. 3.1 lentelę, darbe naudojamų LP tyrimų rezultatai ir matavimo vnt.). Iš 3.1 lenteleje pateiktų duomenų matoma, kad lakiuosiuose pelenuose yra pakankamai didelis $\mathrm{CaO}$ kiekis, kuris siekia $45,17 \%$, chloridu (daugiausia tai $\mathrm{KCl}, \mathrm{NaCl}, \mathrm{MgCl}_{2}$ ) $-19,01 \%$, sieros $-0,82$ 1,56-7,32 \%, randama $\mathrm{Na}_{2} \mathrm{O}, \mathrm{K}_{2} \mathrm{O}, \mathrm{MgO}, \mathrm{Al}_{2} \mathrm{O}_{3}, \mathrm{Fe}_{2} \mathrm{O}_{3}, \mathrm{TiO}_{2}$, bei sunkiujų metalų: švino, kadmio, chromo, vario, gyvsidabrio, molibdeno, alavo, volframo, stroncio ir kt. Nustatyta, kad KDA lakiujų pelenų savitasis elektrinis laidumas siekia $15,26 \mathrm{mS} / \mathrm{cm}, \mathrm{o} \mathrm{pH}=11,93$.

Atsižvelgus ị literatūroje (Wang et al., 2016; Wu et al., 2015) pateiktas rekomendacijas, lakieji pelenai prieš naudojant buvo apdoroti vandeniu (žiūrèti 2.3 poskyrị) ir tai sumažino lakiuosiuose pelenuose sunkiujų metalų ir chloridụ kiekị. Vandeniu apdorotų lakiujų pelenų savitasis elektrinis laidumas sumažeja iki $11,89 \mathrm{mS} / \mathrm{cm}$, o $\mathrm{pH}=11,65$. Nemenkas lakiujų pelenų savitojo elektrinio laidumo sumažèjimas rodo, kad juose sumažèjo krūvị turinčių dalelių. Ruošiant tirpalus ir maišant juos magnetine maišykle, siekiant nustatyti $\mathrm{pH}$ ir savitaji elektrinị laidumą, ant maišyti naudojamų magnetų buvo pastebetas nedidelis kiekis prielipų, manoma, kad tai juodujų metalų, (3.1 pav.) likusių lakiuosiuose pelenuose, dalelès.

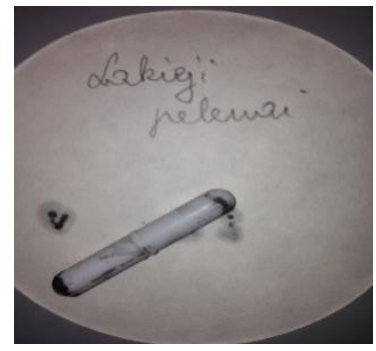

3.1 pav. Juodụjų metalų dalelès lakiụjų pelenų sudètyje

Fig. 3.1. Ferrous metals particles in fly ash 
3.1 lentelè. Lakiujų pelenų eliuato tyrimo rezultatai

Table 3.1. Results of the fly ash eluate test

\begin{tabular}{|c|c|c|}
\hline $\begin{array}{l}\text { Cheminiai elementai, } \\
\text { oksidai ir matavimo } \\
\text { vnt. }\end{array}$ & $\begin{array}{l}\text { Disertacijoje naudojamų LP } \\
\text { tyrimų rezultatai }\end{array}$ & $\begin{array}{l}\text { Visų partijų LP (2017.01.09- } \\
2017.07 .05) \text { tyrimo rezultatai }\end{array}$ \\
\hline $\mathrm{P}_{2} \mathrm{O}_{5}, \%$ & 0,55 & $0,30-0,55$ \\
\hline $\mathrm{Na}_{2} \mathrm{O}, \%$ & 2,65 & $2,65-3,68$ \\
\hline $\mathrm{K}_{2} \mathrm{O}, \%$ & 3,52 & $3,52-4,69$ \\
\hline $\mathrm{CaO}, \%$ & 45,17 & $40,6-45,17$ \\
\hline $\begin{array}{l}\mathrm{MgO}, \% \\
\mathrm{Mg}, \%\end{array}$ & $\begin{array}{l}1,15 \\
0,693\end{array}$ & $\begin{array}{l}1,15-1,39 \\
0,693-0,84\end{array}$ \\
\hline $\mathrm{S}, \%$ & 7,32 & $0,82-7,32$ \\
\hline $\mathrm{SiO}_{2}, \%$ & 0,23 & $0,081-0,23$ \\
\hline $\begin{array}{l}\mathrm{Al}_{2} \mathrm{O}_{3}, \% \\
\mathrm{Al}, \%\end{array}$ & $\begin{array}{l}1,08 \\
0,573\end{array}$ & $\begin{array}{l}1,08-2,56 \\
0,573-1,35\end{array}$ \\
\hline $\begin{array}{l}\mathrm{TiO}_{2}, \mathrm{mg} / \mathrm{kg} \\
\mathrm{Ti}, \mathrm{mg} / \mathrm{kg}\end{array}$ & $\begin{array}{l}1543 \\
925\end{array}$ & $\begin{array}{l}1543-3245 \\
925-1945\end{array}$ \\
\hline $\begin{array}{l}\mathrm{Fe}_{2} \mathrm{O}_{3}, \mathrm{mg} / \mathrm{kg} \\
\mathrm{Fe}, \mathrm{mg} / \mathrm{kg}\end{array}$ & $\begin{array}{l}6938 \\
4853\end{array}$ & $\begin{array}{l}6938-9883 \\
4853-6913\end{array}$ \\
\hline $\begin{array}{l}\mathrm{MnO}_{2}, \mathrm{mg} / \mathrm{kg} \\
\mathrm{Mn}, \mathrm{mg} / \mathrm{kg}\end{array}$ & $\begin{array}{l}334 \\
259\end{array}$ & $\begin{array}{l}334-755 \\
259-477\end{array}$ \\
\hline $\mathrm{As}, \mathrm{mg} / \mathrm{kg}$ & 13,8 & $13,8-23,0$ \\
\hline $\mathrm{Pb}, \mathrm{mg} / \mathrm{kg}$ & 1987 & 1987-3611 \\
\hline $\mathrm{Cd}, \mathrm{mg} / \mathrm{kg}$ & 83,4 & $83,4-143,0$ \\
\hline $\mathrm{Cr}, \mathrm{mg} / \mathrm{kg}$ & 50,5 & $50,5-82,8$ \\
\hline $\mathrm{Cu}, \mathrm{mg} / \mathrm{kg}$ & 625 & $625-1491$ \\
\hline $\mathrm{Ni}, \mathrm{mg} / \mathrm{kg}$ & 12,2 & $12,2-23,7$ \\
\hline $\mathrm{Hg}, \mathrm{mg} / \mathrm{kg}$ & 10,4 & $8,2-15,6$ \\
\hline $\mathrm{Zn}, \mathrm{mg} / \mathrm{kg}$ & 10209 & $8827-14540$ \\
\hline $\mathrm{Ba}, \mathrm{mg} / \mathrm{kg}$ & 237 & $154-448$ \\
\hline $\mathrm{Mo}, \mathrm{mg} / \mathrm{kg}$ & $<1$ & $<1,0-1,90$ \\
\hline $\mathrm{Sn}, \mathrm{mg} / \mathrm{kg}$ & 367 & $301-412$ \\
\hline $\mathrm{Be}, \mathrm{mg} / \mathrm{kg}$ & $<1$ & $<1-1,17$ \\
\hline $\mathrm{Co}, \mathrm{mg} / \mathrm{kg}$ & 5,99 & $5,99-14,4$ \\
\hline $\begin{array}{l}\mathrm{V}_{2} \mathrm{O}_{5}, \mathrm{mg} / \mathrm{kg} \\
\mathrm{V}, \mathrm{mg} / \mathrm{kg}\end{array}$ & $\begin{array}{l}9,55 \\
5,35\end{array}$ & $\begin{array}{l}9,55-28,6 \\
5,35-16,0 \\
\end{array}$ \\
\hline $\mathrm{W}, \mathrm{mg} / \mathrm{kg}$ & $<1$ & $<1-33,5$ \\
\hline $\mathrm{Sr}, \mathrm{mg} / \mathrm{kg}$ & 239 & $239-296$ \\
\hline
\end{tabular}

Lakiujų pelenų mikrostruktūros tyrimai (3.2 pav.) atskleidžia amorfinị lakiụjų pelenų pobūdị, matomos ịvairių formų dalelès. Šių dalelių forma yra apvali, puri struktūra bei nelygus paviršius: mažesnès dalelès prilimpa prie didesnių dalelių, taip sudarydamos heterogeninę, poringą struktūrą (aiškiai matomi atskiri 
grūdeliai), dalelių dydis didesnis nei $10 \mu \mathrm{m}$ (3.2 pav., a ir b). Dalelès turi didelị vidinị poringumą, tai patvirtina ir kitų autorių darbai (Kersch et al., 2002), o literatūroje (An et al., 2014) teigiama, kad dèl tokio didelio lakiujų pelenų vidinio poringumo išsiplauna sunkieji metalai. Dalelių spektroskopijos (elementinès sudèties) tyrimai parodè (3.2 pav. d), kad pagrindiniai elementai yra $\mathrm{Ca}(9,17 \%)$, $\mathrm{Cl}(8,7 \%), \mathrm{O}(31,84 \%), \mathrm{C}(50,29 \%), \mathrm{K}(0,31 \%), \mathrm{Pb}(0,78 \%), \mathrm{S}(2,58 \%), \mathrm{Na}$ $(3,65 \%), \mathrm{Fe}(0,11 \%), \mathrm{Zn}(0,68 \%), \mathrm{Mg}(0,19 \%)$. Taip pat galima matyti kitas iš dalies karbonizavusias daleles, aiškiai matomi kristalizacijos reakcijos produktai, kaip poringa erdve iš dalies užpildoma chaotiškai išsidèsčiusiomis pailgos adatinès formos dalelemis, kurių storis siekia iki $0,1 \mu \mathrm{m}$ (3.2 pav., c). Tokių dalelių egzistavimą patvirtina ir kitų autorių atlikti tyrimai (Garcia-Lodeira et al., 2016).

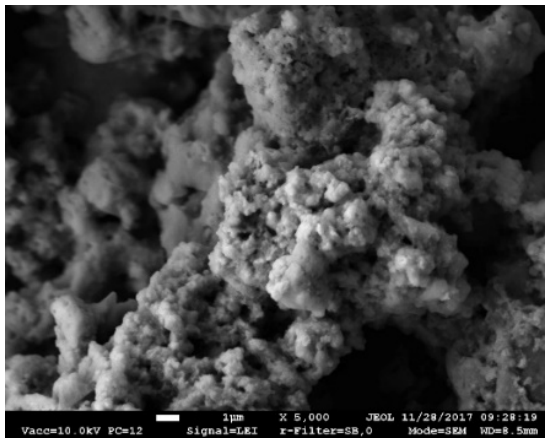

a)

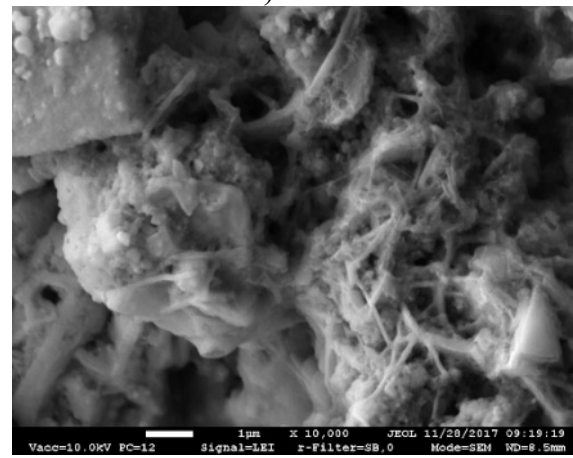

c)

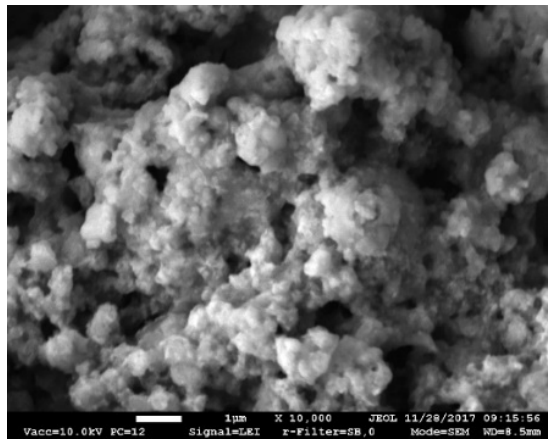

b)

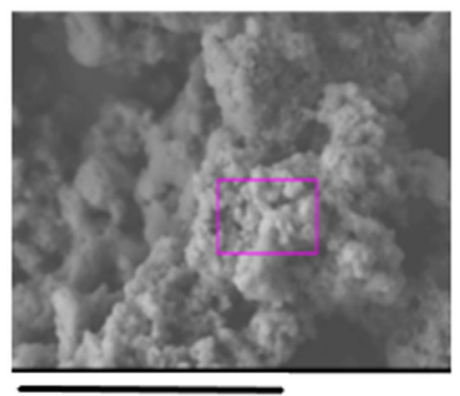

$10 \mu \mathrm{m}$

d)

3.2 pav. Lakiujų pelenų mikrostruktūra: a) $\times 5000$, b) $\times 10000$, c) $\times 10000$, d) EDS tyrimo vieta

Fig. 3.2. The microstructure of the fly ash: a) $\times 5000$, b) $\times 10000$, c) $\times 10000$, d) EDS place of research

Palyginus lakiuju pelenų (3.3 pav., a, b, e) ir vandeniu apdorotų lakiujjų pelenų (3.3 pav., c, d, f) dalelių mikrostruktūrą, matyti, kad vandeniu apdorotų VLP 
dalelių morfologija keičiasi, dalelès tampa akivaizdžiai tankesnès. VLP struktūroje vyrauja mažesnis porų tūris. Atlikti LP ir VLP dalelių spektroskopijos lyginamieji tyrimai pateikti 3.2 lentelèje.

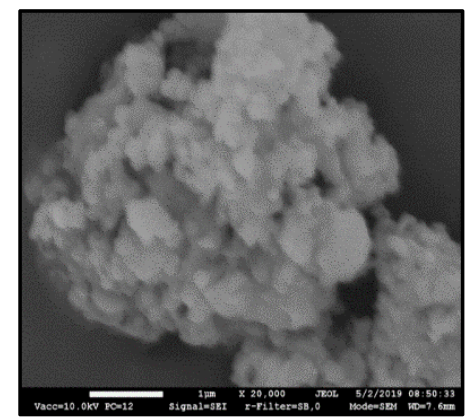

a)

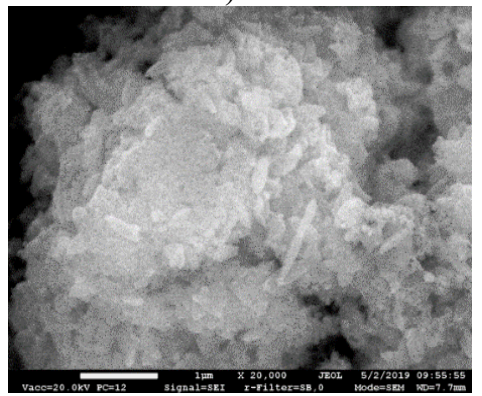

c)

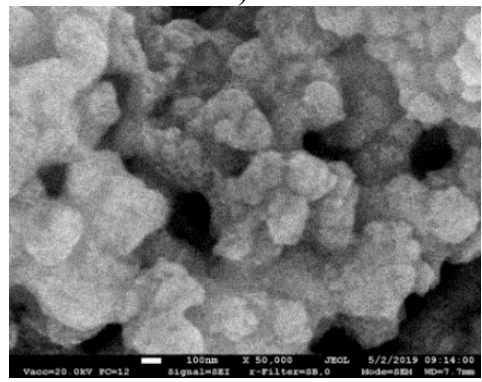

e)

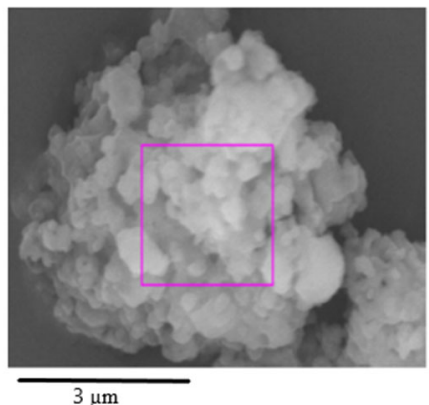

b)

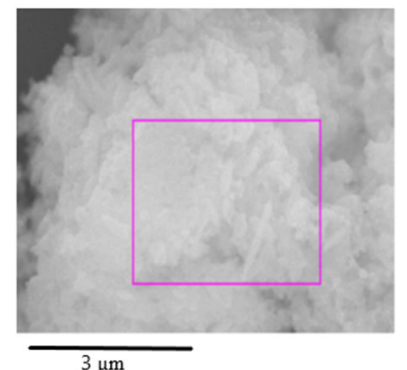

d)

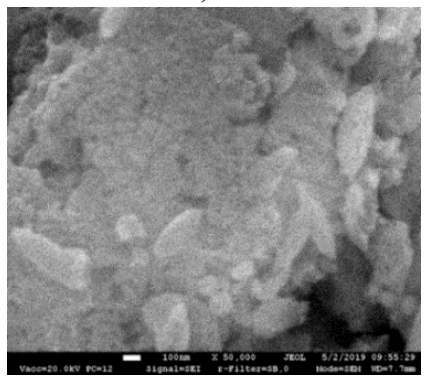

f)

3.3 pav. Lakiųų pelenų ( $a, b$ ir e) ir vandeniu apdorotų lakiųų pelenų (c, $d$ ir f) mikrostruktūra: a) $\times 20000$, b) LP EDS tyrimo vieta, c) $\times 20000$, d) VLP EDS tyrimo vieta, e) $\times 50000, \mathrm{f}) \times 50000$

Fig. 3.3. The microstructure of fly ash ( $a, b$ ir e) and water-treated fly ash (c, $d$ ir $f)$ : a) $\times 20000$, b) LP EDS place of research, c) $\times 20000$, d) VLP EDS place of research, e) $\times 50000, \mathrm{f}) \times 50000$ 
Nustatyta, kad vandeniu apdorotuose lakiuosiuose pelenuose gerokai sumažèja $\mathrm{Ca}, \mathrm{Cl}$, taip pat sumažèja $\mathrm{S}, \mathrm{Cu}, \mathrm{Zn}, \mathrm{Pb}$ kiekiai (3.2 lentelè). Atlikti LP ir VLP EDS lyginamieji tyrimai patvirtina anksčiau aptartus ir literatūros apžvalgoje pateiktus rezultatus, kad, apdorojant lakiuosius pelenus vandeniu, juose sumažèja chloridų, sulfatų ir sunkiụjų metalų kiekiai (Wang et al., 2016; Wu et al., 2015).

3.2 lentelè. Lakiujjų pelenų ir vandeniu apdorotų lakiųjų pelenų dalelių EDS tyrimų lyginamieji rezultatai

Table 3.2. Comparative EDS results of fly ash and water-treated fly ash particles

\begin{tabular}{|c|c|c|c|c|c|c|c|c|}
\hline \multicolumn{9}{|c|}{ Lakiuju pelenu (LP) elementinè sudètis } \\
\hline $\mathrm{C}$ & $\mathrm{O}$ & $\mathrm{Na}$ & $\mathrm{Mg}$ & $\mathrm{Si}$ & $\mathrm{S}$ & $\mathrm{Cl}$ & $\mathrm{K}$ & $\mathrm{Ca}$ \\
\hline 50,29 & 31,84 & 3,65 & 0,19 & 0,18 & 2,58 & 8,70 & 0,31 & 9,17 \\
\hline $\mathrm{Fe}$ & $\mathrm{Ni}$ & $\mathrm{Cu}$ & $\mathrm{Zn}$ & $\mathrm{Pb}$ & & & & \\
\hline 0,11 & 0,08 & 0,46 & 0,68 & 0,78 & & & & \\
\hline \multicolumn{9}{|c|}{ Vandeniu apdorotų lakiujų pelenų (VLP) elementinè sudètis } \\
\hline $\mathrm{C}$ & $\mathrm{O}$ & $\mathrm{Na}$ & $\mathrm{Mg}$ & $\mathrm{Si}$ & $\mathrm{S}$ & $\mathrm{Cl}$ & $\mathrm{K}$ & $\mathrm{Ca}$ \\
\hline 60,18 & 28,18 & 1,93 & 0,08 & 0,24 & 1,62 & 1,59 & 0,14 & 4,79 \\
\hline $\mathrm{Fe}$ & $\mathrm{Ni}$ & $\mathrm{Cu}$ & $\mathrm{Zn}$ & $\mathrm{Pb}$ & & & & \\
\hline 0,07 & 0,09 & 0,35 & 0,52 & 0,30 & & & & \\
\hline
\end{tabular}

Atlikti lakiujų pelenų rentgenografiniai tyrimai (3.4 pav.) parodè, kad pelenuose vyrauja šie mineralai: kalcitas $\left(\mathrm{CaCO}_{3}\right)$, kalcio chloridas $\left(\mathrm{CaCl}_{2}\right)$, kalio kalcio chloridas $\left(\mathrm{KCaCl}_{3}\right)$, kalio chloridas $(\mathrm{KCl})$, natrio chloridas $(\mathrm{NaCl})$, anhidritas $\left(\mathrm{CaSO}_{4}\right)$. Chloridu ir sulfatų druskos yra dominuojanti dalis lakiuosiuose pelenuose. Rentgenografiniai tyrimai negali aptikti grynųjų sunkiųjų metalų, nes jie yra labai nešvarūs, sujungti i ịvairius junginius arba amorfiniai.

Vandeniu apdorotuose lakiuosiuose pelenuose (3.5 pav.) vyrauja kalcito, kalcio chlorido, kalio kalcio chlorido, natrio chlorido, kalio chlorido ir aliuminio chlorido mineralai. Yra žinoma (Chen et al., 2012), kad kalcio chloridas, kalio kalcio chloridas, natrio chloridas, kalio chloridas yra lakiuosiuose pelenuose dominuojantys chloridai. Aliuminio chlorido kiekiai lakiuosiuose pelenuose paprastai nèra labai dideli. Plovimo metu nemaža dalis kalio chlorido $(\mathrm{KCl})$, natrio chlorido $(\mathrm{NaCl})$, kalcio chlorido hidrato $\left(\mathrm{CaCl}_{2} \cdot 2 \mathrm{H}_{2} \mathrm{O}\right)$ pašalinami plaunant kambario temperatūroje (3.2 lentelè). Chen et al. (2012) teigia, kad ịprastai plaunant gali pasišalinti net iki $79 \%$ tirpių chloridų. Todèl, išsiplovus minètiems chloridams, rentgenogramoje išryškejja mažiau tirpaus aliuminio chlorido smailès. 


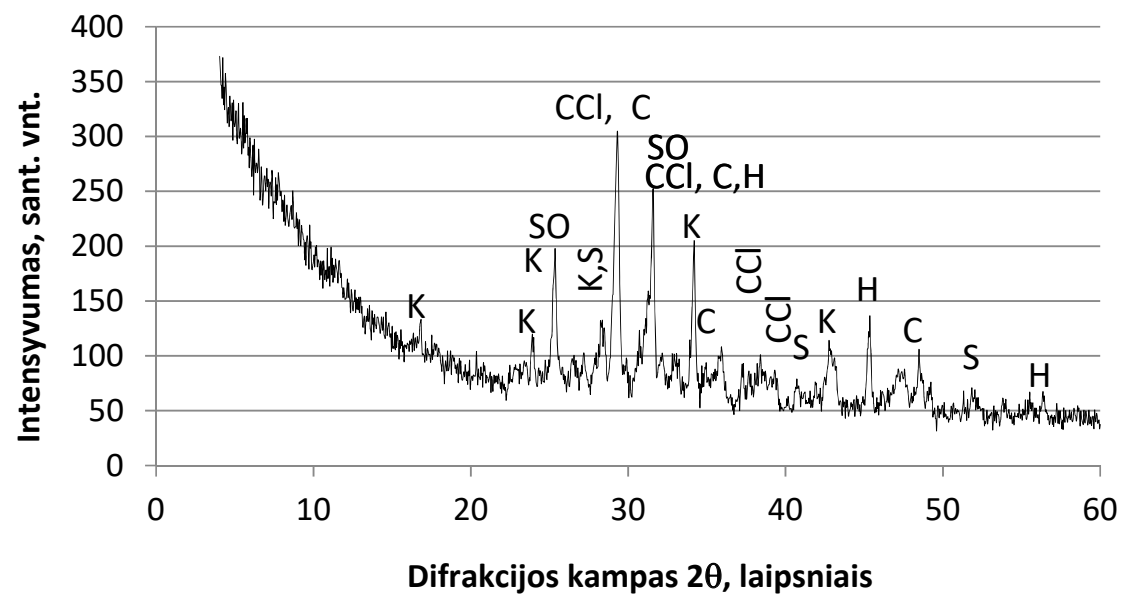

3.4 pav. Lakiujų pelenų rentgenograma: $\mathrm{CCl}$ - kalcio chloridas; $\mathrm{C}$ - kalcitas; $\mathrm{K}$ - kalio kalcio chloridas; $\mathrm{H}$ - natrio chloridas; $\mathrm{S}$ - kalio chloridas; $\mathrm{SO}$ - anhidritas

Fig. 3.4. The $\mathrm{X}$-ray diffraction pattern of fly ash: $\mathrm{CCl}$ - calcium chloride;

$\mathrm{C}$ - calcite; $\mathrm{K}$ - potassium calcium chloride; $\mathrm{H}$ - halite; $\mathrm{S}$ - sylvite; $\mathrm{SO}$ - anhidryte

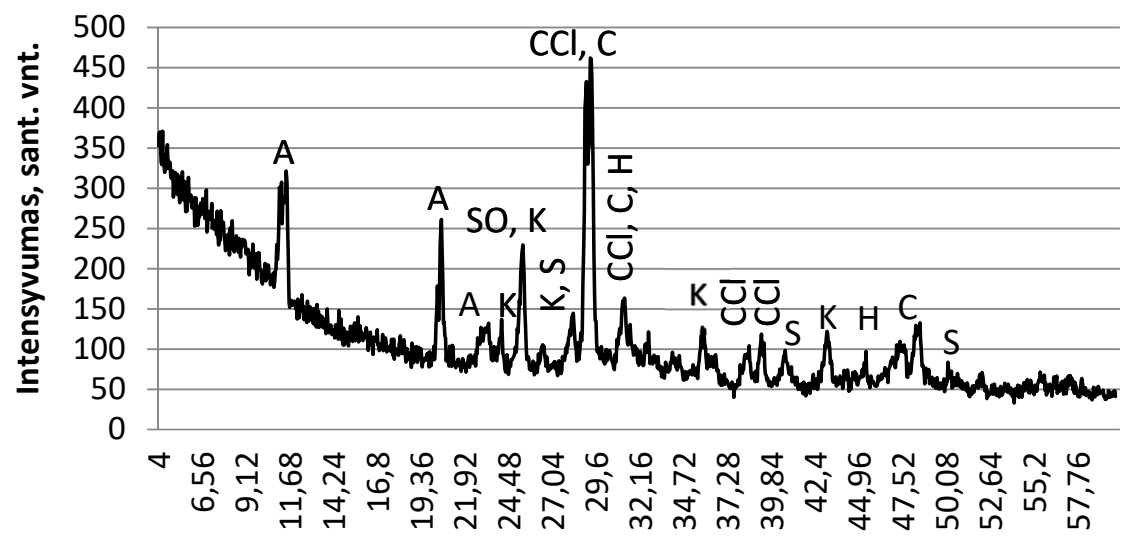

Difrakcijos kampas $2 \theta$, laipsniais

3.5 pav. Vandeniu apdorotų lakiųų pelenų rentgenograma: $\mathrm{CCl}$ - kalcio chloridas; $\mathrm{C}$ - kalcitas; $\mathrm{K}$ - kalio kalcio chloridas; $\mathrm{H}$ - natrio chloridas; $\mathrm{S}$ - kalio chloridas;

A - aliuminio chloridas

Fig. 3.5. The X-ray diffraction pattern of water-treated of fly ash: $\mathrm{CCl}$ - calcium chloride; $\mathrm{C}$ - calcite; $\mathrm{K}$ - potassium calcium chloride; $\mathrm{H}$ - halite; $\mathrm{S}$ - sylvite;

A - aluminum chloride 
Atlikti lakiųų pelenų dalelių granuliometriniai tyrimai (3.6 pav.) parodė, kad dalelių dydis yra nuo $1 \mu \mathrm{m}$ iki $100 \mu \mathrm{m}$, apie $50 \%$ lakiujų pelenų sudare $10,82 \mu \mathrm{m}$ dydžio dalelès, vidutinis dalelių skersmuo - 17,21 $\mu \mathrm{m}$. Apie $50 \%$ vandeniu apdorotų lakiưu pelenų (3.7 pav.) sudarè 17,33 $\mu \mathrm{m}$ dydžio dalelès, vidutinis dalelių skersmuo $-28,21 \mu \mathrm{m}$. VLP dalelių vidutinio skersmens padidejjimą, palyginus su LP dalelėmis, lemia dalelių apdorojimo vandeniu procesas, kai iš LP išsiplauna tam tikras sunkiụjų metalų ir chloridų kiekis, o likusios dalelès galimai sušoka i stambesnius junginius.

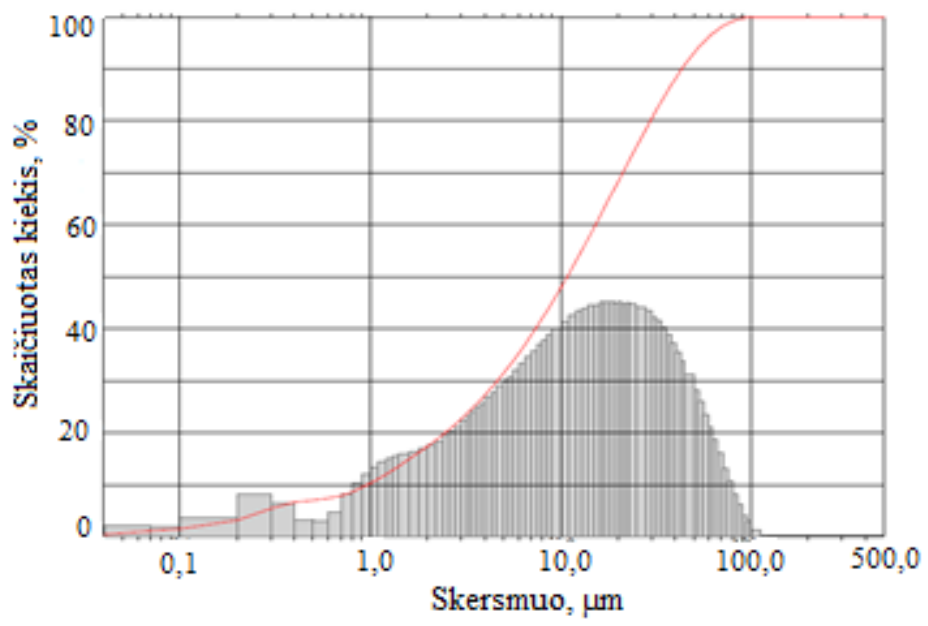

3.6 pav. Lakiujų pelenų granuliometrinè sudètis

Fig. 3.6. The granulometric composition of fly ash

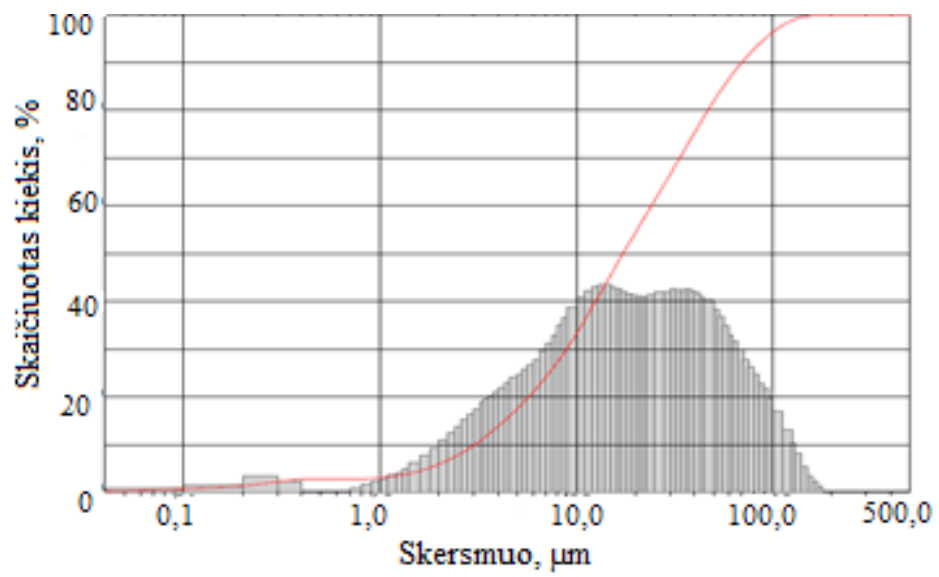

3.7 pav. Vandeniu apdorotų lakiujų pelenų granuliometrinè sudètis

Fig. 3.7. The granulometric composition pattern of water-treated of fly ash 


\subsubsection{Dugno pelenų tyrimai}

Sunkiụjų metalų kiekiai dugno pelenuose nustatyti (eliuato tyrimai pagal EN ISO 11885-E22) ir pateikti tiriant dugno pelenus nuo 2017-01-09 iki 2017-07-05 (3.3 lentelè). Tyrimų rezultatai rodo, kad skirtingų partijų dugno pelenų cheminių elementų vertès skiriasi labai plačiai. Toliau tyrimams atlikti buvo naudojami vienos partijos dugno pelenai (žr. 3.3 lentelę, darbe naudojamų DP tyrimų rezultatai ir matavimo vnt.).

Nustatyta, kad dugno pelenus sudaro: 47,6 \% $\mathrm{SiO}_{2}, 8,4 \% \mathrm{Al}_{2} \mathrm{O}_{3}, 9,7 \%$ $\mathrm{Fe}_{2} \mathrm{O}_{3}, 20,8 \% \mathrm{CaO}, 2,7 \% \mathrm{MgO}, 2,9 \% \mathrm{SO}_{3}, 1,3 \% \mathrm{~K}_{2} \mathrm{O}, 3,0 \% \mathrm{Na}_{2} \mathrm{O}, 0,4 \% \mathrm{Cl}$, kaitmenys $-3,2 \%$. Dugno pelenų granuliometrinę sudètị sudarè: $2,5-1,25 \mathrm{~mm}$ dalelių - 13,7\%, 1,25-0,63 $\mathrm{mm}$ dalelių - 64,63\%,0,63-0,315 mm dalelių $16,97 \%,<0,315 \mathrm{~mm}$ dalelių $-4,7 \%$.

3.3 lentelė. Dugno pelenuose esančių sunkiujų metalų (eliuato) tyrimo rezultatai

Table 3.3. Test results of heavy metals (eluate) in bottom ash

\begin{tabular}{|l|l|l|}
\hline $\begin{array}{l}\text { Cheminis ele- } \\
\text { mentas ir mata- } \\
\text { vimo vnt. }\end{array}$ & $\begin{array}{l}\text { Disertacijoje naudojamo dugno } \\
\text { pelenų eliuato rezultatai }\end{array}$ & $\begin{array}{l}\text { Visu partiju DP (2017.01.09- } \\
2017.07 .05) \text { tyrimo rezultatai }\end{array}$ \\
\hline $\mathrm{As}, \mathrm{mg} / \mathrm{kg}$ & $<0,01$ & $<0,01-0,022$ \\
\hline $\mathrm{Pb}, \mathrm{mg} / \mathrm{kg}$ & $<24,63$ & $8,7-24,63$ \\
\hline $\mathrm{Cd}, \mathrm{mg} / \mathrm{kg}$ & $<0,005$ & $<0,005-0,022$ \\
\hline $\mathrm{Cr}, \mathrm{mg} / \mathrm{kg}$ & 0,158 & $0,13-0,31$ \\
\hline $\mathrm{Cu}, \mathrm{mg} / \mathrm{kg}$ & 3,65 & $0,91-3,65$ \\
\hline $\mathrm{Ni}, \mathrm{mg} / \mathrm{kg}$ & $<0,1$ & - \\
\hline $\mathrm{Hg}, \mathrm{mg} / \mathrm{kg}$ & $<0,002$ & - \\
\hline $\mathrm{Zn}, \mathrm{mg} / \mathrm{kg}$ & 11,89 & $7,9-25,67$ \\
\hline $\mathrm{Ba}, \mathrm{mg} / \mathrm{kg}$ & 1,88 & $1,5-2,39$ \\
\hline $\mathrm{Mo}, \mathrm{mg} / \mathrm{kg}$ & 0,269 & $0,269-0,38$ \\
\hline $\mathrm{Sb}, \mathrm{mg} / \mathrm{kg}$ & 0,0405 & $0,0405-0,25$ \\
\hline $\mathrm{Se}, \mathrm{mg} / \mathrm{kg}$ & $<0,03$ & - \\
\hline
\end{tabular}

Dugno pelenų drègnumas siekia $14,4 \%$, savitasis elektrinis laidumas $899,5 \mu \mathrm{S} / \mathrm{cm}, \mathrm{pH}=10,23$. Sausoji liekana DP sudaro $85,6 \%$, bendros organinès anglies kiekis $-0,26 \%$, ištirpusi organinè anglis $-81,8 \mathrm{mg} / \mathrm{kg}$. Chloridų kiekis dugno pelenuose siekia $2210 \mathrm{mg} / \mathrm{kg}$, sulfatu kiekis - $5751 \mathrm{mg} / \mathrm{kg}$, 
fluoridu $-<3 \mathrm{mg} / \mathrm{kg}$. DP randami šie sunkieji metalai: chromas, varis, nikelis, švinas, cinkas, gyvsidabris, arsenas, kadmis, stibis, selenas. Kaip matoma iš pateiktų duomenų, sunkiujų metalų kiekai, taip pat chloridų ir sulfatų kiekiai nėra dideli ir neviršija LR AM ịsakyme D1-805 pateiktų verčių. Todẻl, pagal galiojantị normatyvinị dokumentą (LR AM ịsakymas D1-805), komunalinių deginimo atliekų šlakas ir pelenai gali būti naudojami civilinèje ir statybos inžinerijoje (žr. 1.1 lentelę). Kaip jau buvo minèta, ruošiant tirpalus ir maišant juos magnetine maišykle, ant maišyti naudojamų magnetų buvo pastebètos metalų prielipos. Dugno pelenuose jų kiekis vizualiai matomas didesnis nei lakiuosiuose pelenuose (3.8 pav.). Nors iš DP tiek spalvotieji, tiek juodieji metalai buvo atskiriami, tačiau galima teigti, kad technologiniai dugno pelenų apdorojimo procesai neužtikrina visiško juodųu metalų atskyrimo, todèl nedideli jų kiekiai lieka dugno pelenuose.

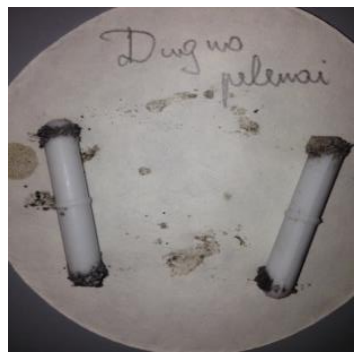

3.8 pav. Juodụjų metalų dalelès dugno pelenų sudètyje

Fig. 3.8. Ferrous metals particles in bottom ash

Dugno pelenų mikrostruktūroje vyrauja ịvairių formų poringų, stambesnių, grublètu paviršiumi dalelių, kurios susideda iš smulkesnių dalelių (3.9 pav., a ir b). Pagrindiniai šių dalelių elementai yra Ca (19,03\%), Al (6,65\%), O (57,60 \%), Si (9,50 \%), Mg (2,20\%), K (1,40\%), Zn (2,71\%), Cl (0,91\%) (3.9 pav. d). Akivaizdu, kad vyrauja deguonies elementas, todèl dauguma cheminių elementu dugno pelenuose dažniausiai yra oksidai.

Taip pat matomos (3.9 pav., c) nuo $5 \mu \mathrm{m}$ iki $10 \mu \mathrm{m}$ pailgos lygiu paviršiumi, gana tankios struktūros dalelès, o kai kur ant jų paviršiaus pastebimos smulkesnès apvalių formų dalelių nuolaužos. Spektroskopijos tyrimas parodè, kad pagrindiniai pailgų dalelių elementai yra $\mathrm{Ca}(24,20 \%), \mathrm{Al}(5,73 \%), \mathrm{O}(65,41 \%), \mathrm{Si}$ (2,63 \%), $\mathrm{Mg}(0,40 \%), \mathrm{K}(0,28 \%), \mathrm{Zn}(0,90 \%), \mathrm{Cl}$ (0,46\%) (3.9 pav., d).

Atliktas dugno pelenų rentgenografinis tyrimas (3.10 pav.) parode, kad juose vyrauja kvarco $\left(\mathrm{SiO}_{2}\right)$ ir kalcito $\left(\mathrm{CaCO}_{3}\right)$ mineralai. Panašią dugno pelenų mineraloginę sudètị nustatè savo darbuose ir kiti autoriai (Lin et al., 2006; Wei et al., 2011). 


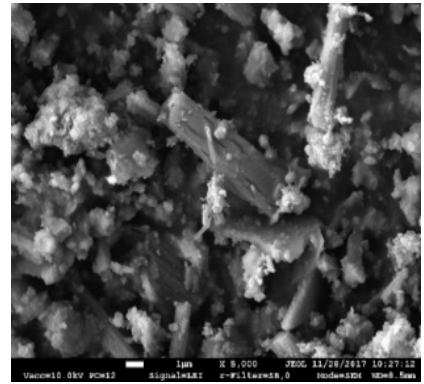

a)

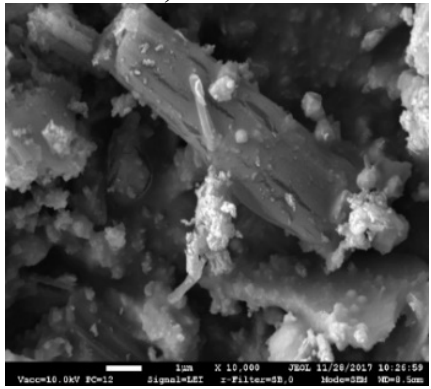

c)

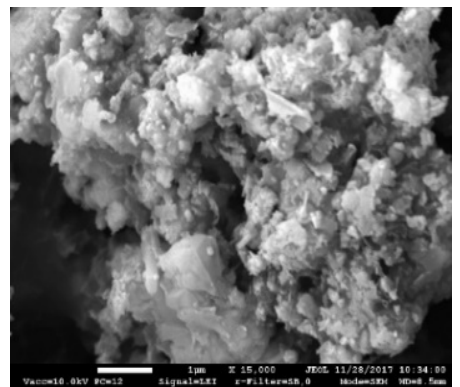

b)

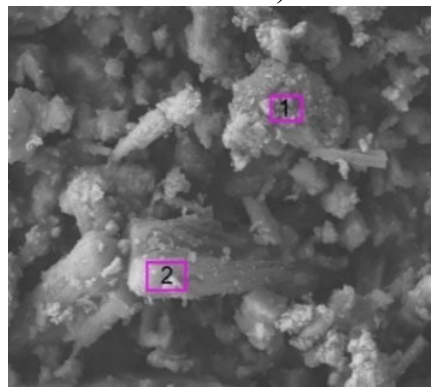

d)

3.9 pav. Dugno pelenų mikrostruktūra: a) $\times 5000$, b) $\times 15000$, c) $\times 10000$, d) DP EDS tyrimo vieta $\left(1-\mathrm{SiO}_{2} ; 2-\mathrm{CaCO}_{3}\right)$

Fig. 3.9. Microstructure of the bottom ash: a) $\times 5000$, b) $\times 15000$, c) $\times 10000$, d) DP EDS place of research $\left(1-\mathrm{SiO}_{2} ; 2-\mathrm{CaCO}_{3}\right)$

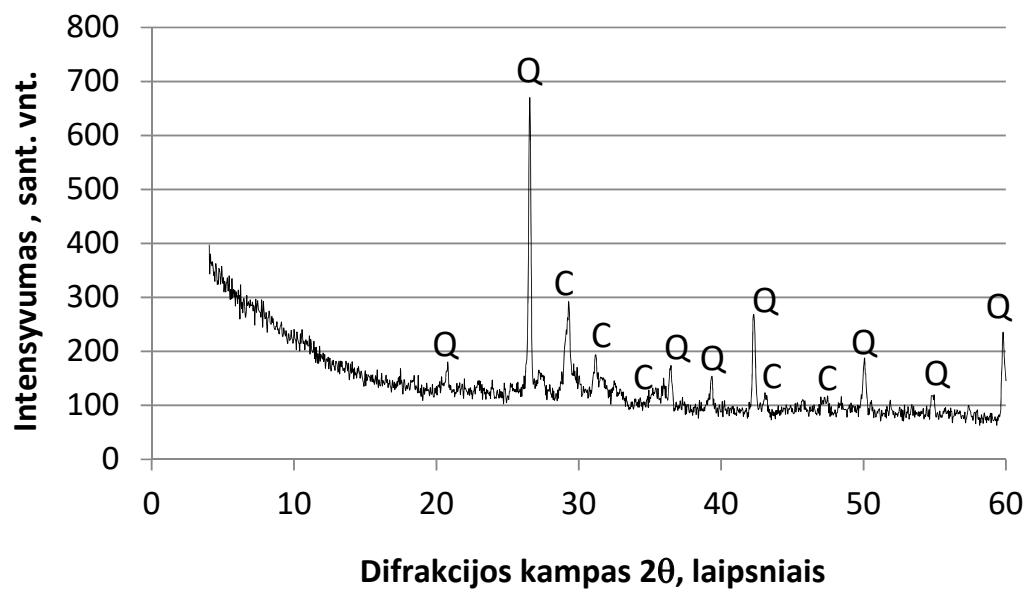

3.10 pav. Dugno pelenų rentgenograma: $\mathrm{Q}$ - kvarcas; $\mathrm{C}$ - kalcitas Fig. 3.10. The X-ray diffraction pattern of bottom ash: $\mathrm{Q}$ - quartz; $\mathrm{C}$ - calcite 


\subsection{Keraminių šukių su lakiaisiais pelenais tyrimai}

\subsubsection{Lakiųjų pelenų ịtaka keraminių šukių mineraloginei sudèčiai}

Kontrolinèje keraminèje šukejje (CS) identifikuojami kvarco $\left(\mathrm{SiO}_{2}\right)$, hematito $\left(\mathrm{Fe}_{2} \mathrm{O}_{3}\right)$, albito-anortito $(\mathrm{Ca}, \mathrm{Na})(\mathrm{SiAl})_{4} \mathrm{O}_{8}$, špinelio $\left(\mathrm{MgAl}_{2} \mathrm{O}_{4}\right)$, diopsido $\left(\mathrm{MgCaSi}_{2} \mathrm{O}_{6}\right)$ mineralai (3.11 pav.).

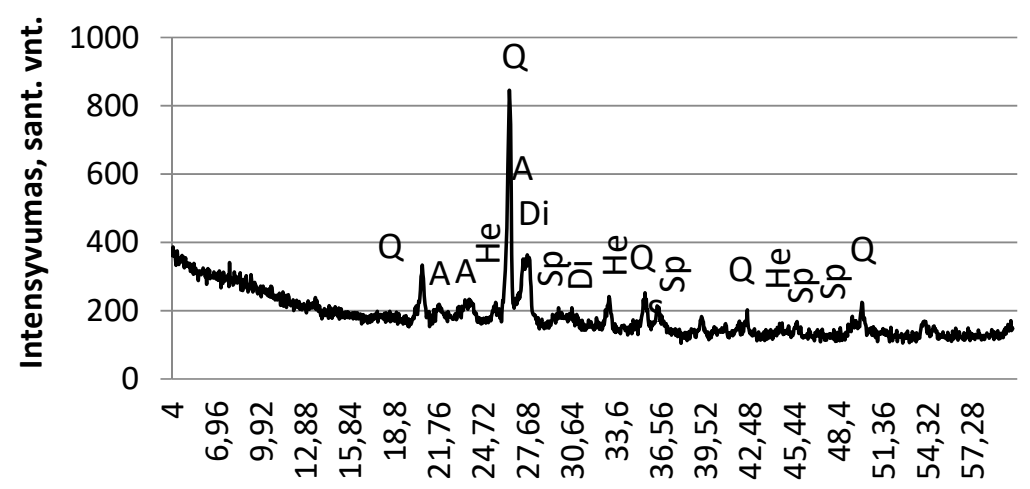

Difrakcijos kampas $2 \theta$, laipsniais

3.11 pav. CS Keraminès šukès rentgenograma $(\mathrm{Q}$ - kvarcas, $A$ - albitas-anortitas,

$\mathrm{Di}$ - diopsidas, $\mathrm{Sp}$ - špinelis, $\mathrm{He}$ - hematitas)

Fig. 3.11. The X-ray diffraction pattern of CS clay bricks: (Q - quartz, A - albiteanortite, $\mathrm{Di}$ - diopside, $\mathrm{Sp}$ - spinel, $\mathrm{He}$ - hematite)

Atlikti keraminių šukių mineraloginiai tyrimai parodè, kad bandiniuose su LP ir VLP identifikuoti izomorfiniai mineralai, plagioklazai - albitas-anortitas $(\mathrm{Ca}, \mathrm{Na})(\mathrm{SiAl})_{4} \mathrm{O}_{8}$, hematitas $\left(\mathrm{Fe}_{2} \mathrm{O}_{3}\right)$, špinelis $\left(\mathrm{MgAl}_{2} \mathrm{O}_{4}\right)$, diopsidas $\left(\mathrm{MgCaSi}_{2} \mathrm{O}_{6}\right)$, taip pat kalcio sulfatas $\left(\mathrm{CaSO}_{4}\right)(3.12-3.15$ pav.). Analizuojant keraminių šukių su LP $(3.12,3.13$ pav.) rentgenografinius tyrimus, nustatyta, kad šiek tiek skiriasi nustatytų diopsido, anortito ir špinelio mineralų intensyvumai. Nustatyta, kad įdedant 2,5\% LP, keraminèje šukejje identifikuoto diopsido ir špinelio mineralų intensyvumas yra mažesnis nei keraminès šukès su $5 \%$ LP. Reikètų pabrèžti, kad kiekybinè nagrinėjamų smailių intensyvumo analizė yra gana ribota, tačiau literatūroje (Mao et al., 2016; Tang et al., 2010, 2014; Lu et al., 2012, 2015) teigiama, kad minètų mineralų susiformavimui įtakos gali turèti lakiuosiuose pelenuose esantys sunkieji metalai. 


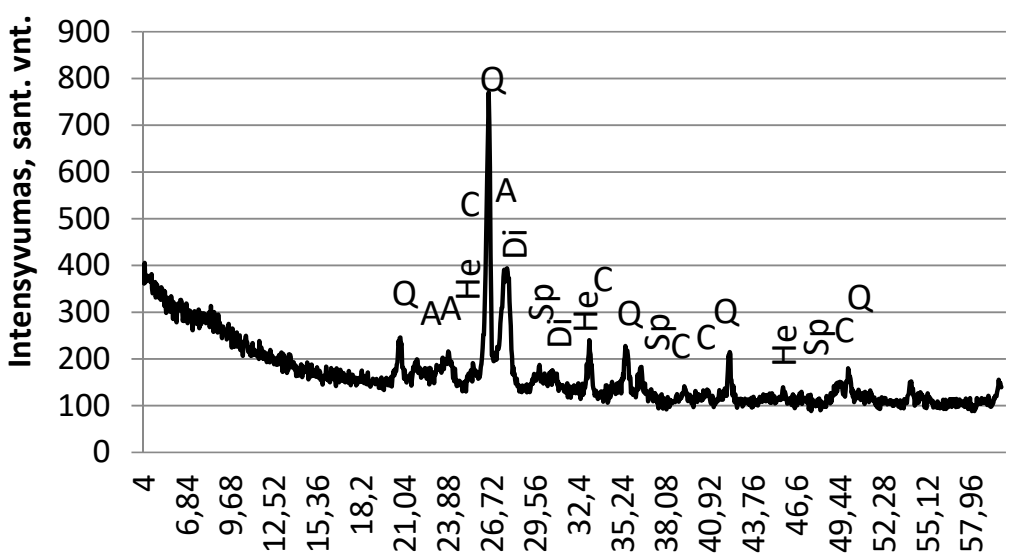

Difrakcijos kampas $2 \theta$, laipsniais

3.12 pav. FA 2,5 keraminès šukès rentgenograma: ( $\mathrm{Q}$ - kvarcas, $\mathrm{A}$ - albitas-anortitas, $\mathrm{Di}$ - diopsidas, $\mathrm{Sp}$ - špinelis, He - hematitas, C - kalcio sulfatas)

Fig. 3.12. The X-ray diffraction pattern of FA 2,5 clay bricks: (Q - quartz, A - albiteanortite, $\mathrm{Di}$ - diopside, $\mathrm{Sp}$ - spinel, $\mathrm{He}$ - hematite, $\mathrm{C}$ - calcium sulphate)

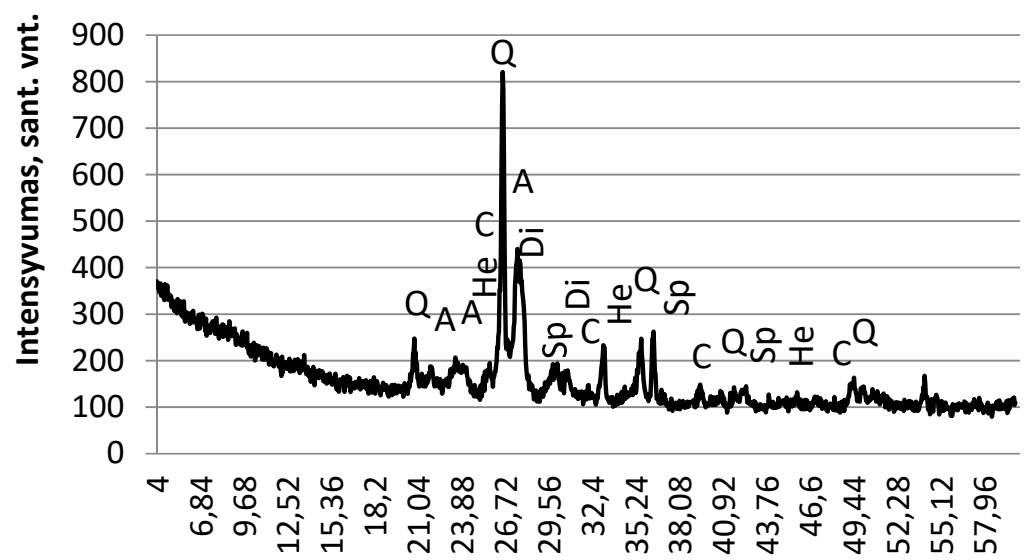

Difrakcijos kampas 2 $\theta$, laipsniais

3.13 pav. FA 5,0 keraminès šukès rentgenograma: ( $\mathrm{Q}$ - kvarcas, $\mathrm{A}$ - albitas-anortitas, $\mathrm{Di}$ - diopsidas, $\mathrm{Sp}$ - špinelis, He - hematitas, $\mathrm{C}$ - kalcio sulfatas)

Fig. 3.13. The X-ray diffraction pattern of FA 5,0 clay bricks: (Q - quartz, A - albiteanortite, $\mathrm{Di}$ - diopside, $\mathrm{Sp}$ - spinel, $\mathrm{He}$ - hematite, $\mathrm{C}$ - calcium sulphate) 
Sunkieji metalai, tokie kaip $\mathrm{Cu}, \mathrm{Zn}, \mathrm{Ni}$ ir kt., gali ịsiterpti ị špinelio ar diopsido struktūrą ir taip daryti įtaką jų identifikavimui bei intensyvumui (Mao et al., 2016; Tang et al., 2010, 2014; Lu et al., 2012, 2015). Todèl, analizuojant gautus rezultatus, manoma, kad lakiujų pelenų užterštumo sunkiaisiais metalais laipsnis daro įtaką diopsido, špinelio mineralų susidarymo keraminèje šukejje su LP ir VLP procesui. Galima iškelti hipotezę, kad lakiuosiuose pelenuose esantys sunkieji metalai ịsiterpia ị diopsido $\left(\mathrm{CuCaSi}_{2} \mathrm{O}_{6}, \mathrm{ZnCaSi}_{2} \mathrm{O}_{6}\right)$, špinelio $\left(\mathrm{ZnAl}_{2} \mathrm{O}_{4}\right)$ mineralu struktūrą, todèl rentgenogramose stebimas šiek tiek padidèjęs jų intensyvumas.

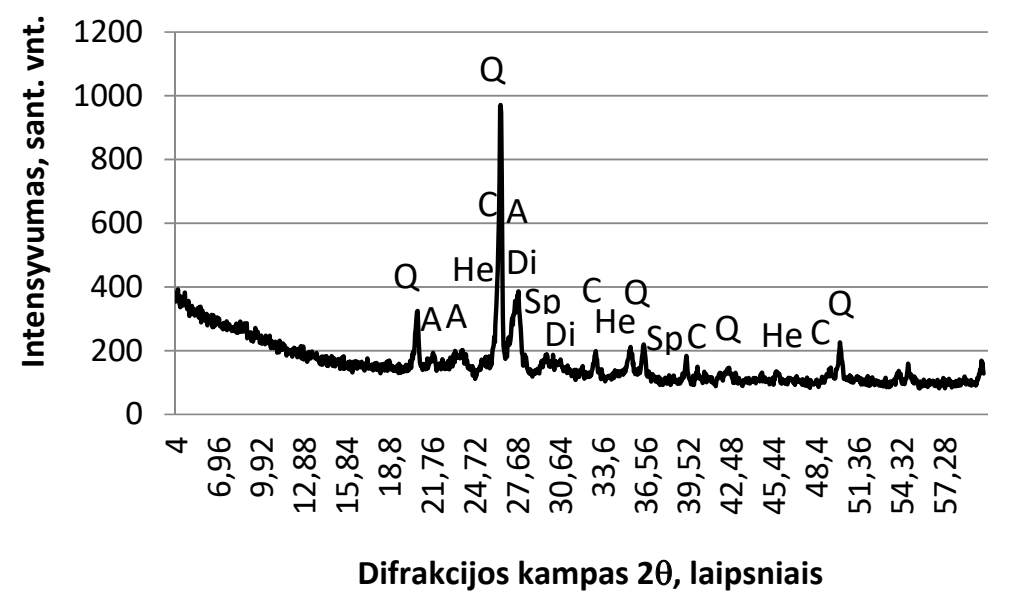

3.14 pav. FAW 2,5 keraminès šukès rentgenograma: $(\mathrm{Q}$ - kvarcas, $\mathrm{A}$ - albitas-anortitas, Di - diopsidas, $\mathrm{Sp}$ - špinelis, He - hematitas, $\mathrm{C}$ - kalcio sulfatas)

Fig. 3.14. The X-ray diffraction pattern of FAW 2,5 clay bricks: (Q - quartz, A - albiteanortite, $\mathrm{Di}$ - diopside, $\mathrm{Sp}$ - spinel, $\mathrm{He}$ - hematite, $\mathrm{C}$ - calcium sulphate)

Taip pat manoma, kad anortito mineralo intensyvumas galimai mažeja, nors, atsižvelgiant $\mathfrak{i}$ anortito, diopsido mineralų smailių dalinị sutapimą, tai sunkiai nustatoma, tačiau toliau atlikti DTA ir mechaninių savybių tyrimai tai patvirtina. İdedant ị formavimo mases VLP ir išdegant jas $1000{ }^{\circ} \mathrm{C}$ temperatūroje, diopsido ir špinelio intensyvumas sumažeja, palyginus su keramine šuke su LP, nes, apdorojant lakiuosius pelenus vandeniu, iš jų pasišalina dalis sunkiųjų metalų, kurie galètų ịsiterpti ị mineralų struktūrą. Taip pat reikia atkreipti dèmesį, kad keraminèse šukèse su LP ir VLP identifikuojamas kalcio sulfato mineralas (3.123.15 pav., jis uždengiamas kvarco smaile, žr. 3.16 pav.). Šio mineralo susiformavimui daro įtaką didelis kalcio ir sulfatų kiekis lakiuosiuose pelenuose. Kalcio sulfato mineralas nèra pageidaujamas mineralas keraminių gaminių pramoneje, nes jis dèl savo savybiu - didelio tūrio ir formavimosi porose galimybių, gali nei- 
giamai veikti keraminių šukių struktūrą, didindamas poringumą. Toliau disertacijoje atlikti tyrimai patvirtina, kad minètas mineralas didina keraminių šukių poringumą.

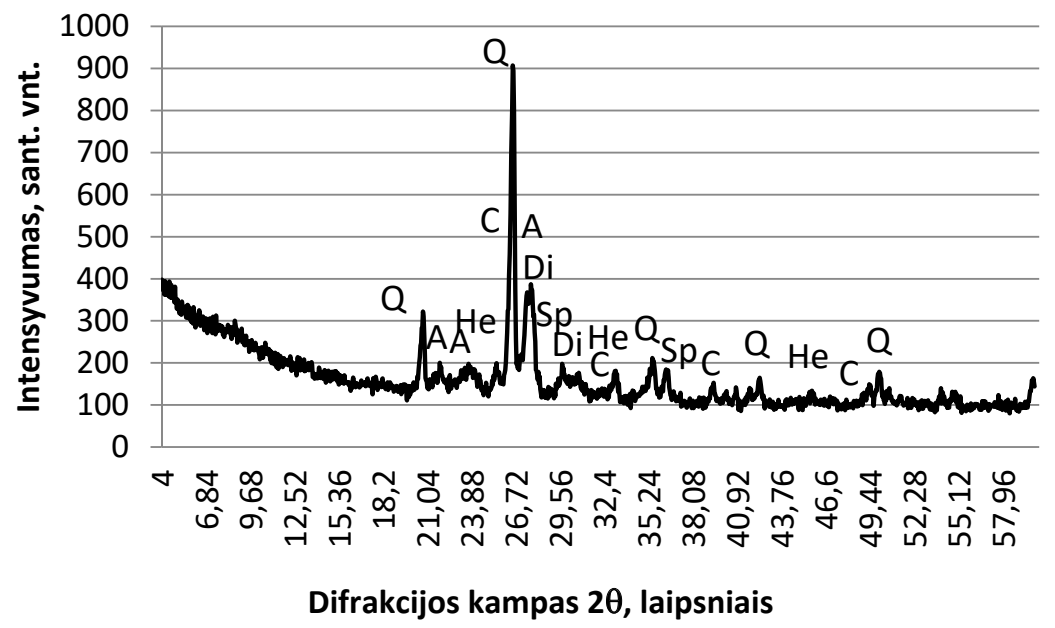

3.15 pav. FAW 5,0 keraminès šukès rentgenograma: (Q - kvarcas, $\mathrm{A}$ - albitas-anortitas, $\mathrm{Di}$ - diopsidas, $\mathrm{Sp}$ - špinelis, He - hematitas, $\mathrm{C}$ - kalcio sulfatas)

Fig. 3.15. The X-ray diffraction pattern of FAW 5,0 clay bricks: (Q - quartz, A - albiteanortite, $\mathrm{Di}$ - diopside, $\mathrm{Sp}$ - spinel, $\mathrm{He}$ - hematite, $\mathrm{C}$ - calcium sulphate)

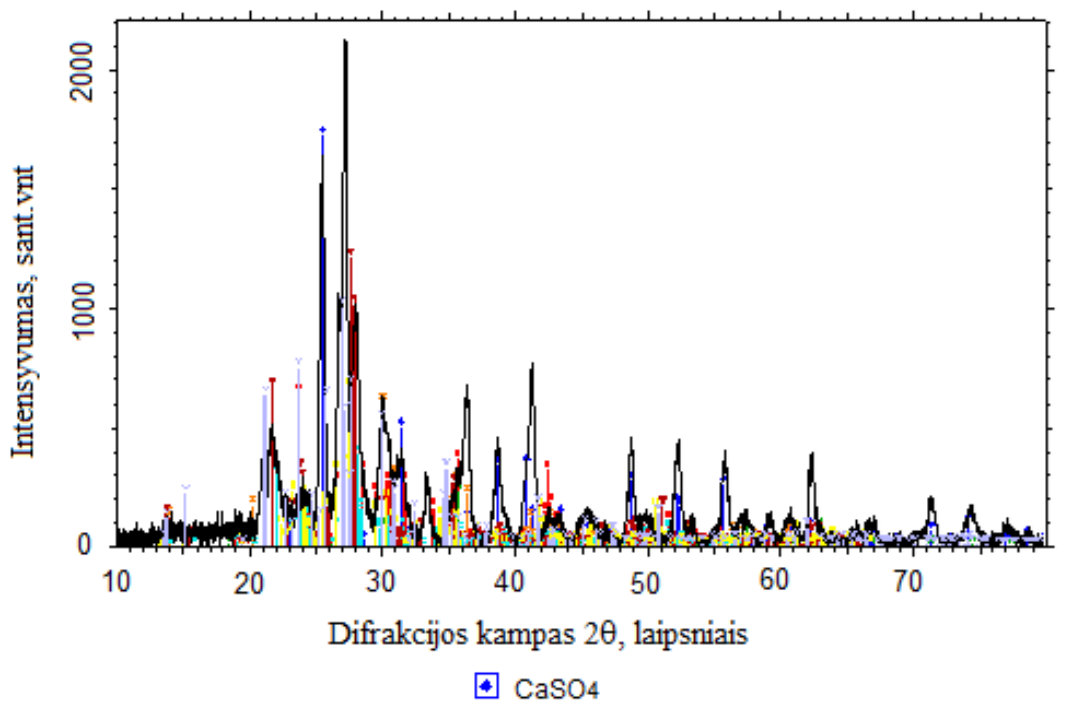

3.16 pav. FAW 2,5 keraminès šukès rentgenograma Fig. 3.16. The X-ray diffraction pattern of FAW 2.5 clay brick 


\subsubsection{Lakiụjụ pelenų ịtaka estetinei keraminių šukių kokybei}

Atlikti keraminių šukių su LP apžiūros vizualiniai tyrimai parodè, kad bandinių paviršiuje su $5 \%$ ir didesniu LP kiekiu matomos išsūdos (3.17 pav.). Literatūroje (Brocken \& Nijland, 2004; Rodriguez-Navarro \& Doehne, 1999; Lubelli et al., 2004; Вахрамова et al., 2000; Tsui et al., 2003) nurodoma, kad dažniausiai išsūdų atsiradimui ịtaką daro žaliavoje ar ịvairiuose prieduose esantys lengvai tirpūs sulfatai $\left(\mathrm{Na}_{2} \mathrm{SO}_{4}, \mathrm{~K}_{2} \mathrm{SO}_{4}\right.$ ir $\left.\mathrm{MgSO}_{4}\right)$, taip pat chloridai $(\mathrm{NaCl})$. Kiti autoriai teigia (Dondi et al., 1997), kad jei medžiagoje kalcio kiekis yra $0,2 \%$, tai ant degtų gaminių gali atsirasti $\mathrm{CaCO}_{3}$ išsūdų, o jei Ca kiekis $0,1 \%-\mathrm{CaSO}_{4}$ išsūdų.

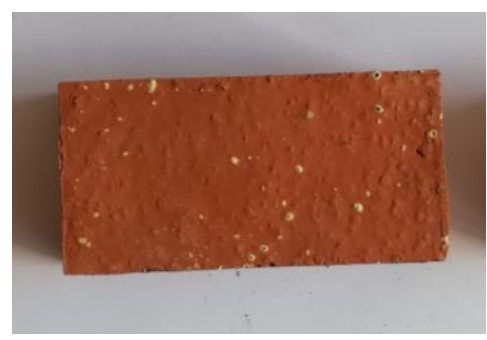

3.17 pav. Keraminès šukès su 5,0 \% lakiųjų pelenų bandinio paviršius (FA 5,0 keraminè sukè)

Fig. 3.17. Clay brick with $5.0 \%$ fly ash efflorescence overview

(FA 5.0 clay brick)

Anksčiau atlikti lakiųų pelenų tyrimai (žr. 3.2 pav., 3.1 lentelè) parodè, kad lakiuosiuose pelenuose yra nemažas sulfatų ir chloridų kiekis. Šiuo atveju identifikuotas išsūdų mineralas - kalcio sulfatas (3.18 pav.). Kalcio sulfatas ne tik susidaro gaminio paviršiuje ir neigiamai veikia estetini gaminio vaizdą, bet ir dèl savo formavimosi ypatumų šie sulfatai linkę formuotis labiau lokalizuotose vietose, porose bei daryti neigiamą ịtaką keraminių šukių struktūrai, o tai mažina keraminių gaminių ilgaamžiškumą.

Reikia pabrèžti, kad, naudojant VLP, tokių išsūdų ant keraminių šukių paviršiaus nesusidarè. Atkreiptinas dėmesys, kad keraminių šukių paviršiuje atsiradusių išsūdų spalva nėa visiškai balta, o turi geltoną atspalvị (3.17 pav.). Atlikus papildomus, būtent išsūdų taškų rentgeno struktūros tyrimus, identifikuotas tik kalcio sulfato mineralas (3.18 pav.). Tačiau literatūroje (Вахрамова et al., 2000) teigiama, kad geltoną atspalvị išsūdoms gali suteikti vanadžio druskos. Nagrinèjamų komunalinių deginimo atliekų lakiuosiuose pelenuose yra $9,55 \mathrm{mg} / \mathrm{kg} \mathrm{V} \mathrm{V}_{2} \mathrm{O}_{5}$ (3.1 lentelè). Taip pat geltoną atspalvị gali suteikti ir chromo druskos, kurių lakiuosiuose pelenuose yra apie $50 \mathrm{mg} / \mathrm{kg}$. Todèl manoma, kad atsiradęs geltonas išsūdų atspalvis - tai vanadžio arba chromo druskų junginiai, tačiau tiksliai juos identifikuoti dẻl mažo šių druskų kiekio išsūdose yra gana sudètinga. 


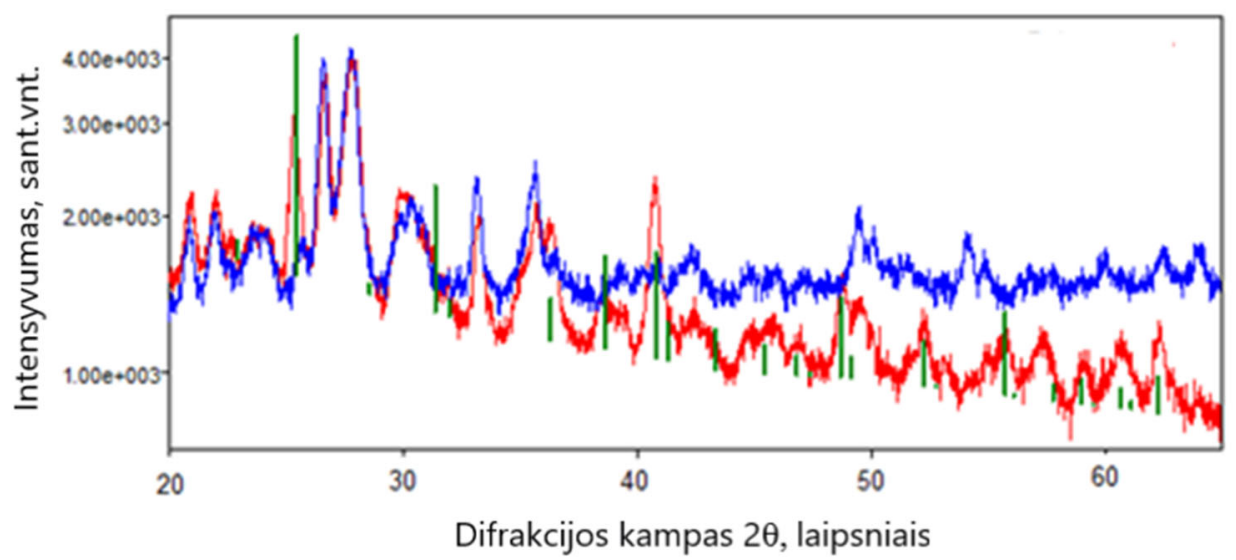

3.18 pav. Keraminès šukès išsūdų rentgenograma $\left(\mathrm{CaSO}_{4}\right.$ - raudona spalva)

Fig. 3.18. Clay brick efflorescence X-ray diffraction pattern $\left(\mathrm{CaSO}_{4}-\right.$ red colour $)$

\subsubsection{Keraminių šukių su lakiaisiais pelenais termografiniai tyrimai}

Kontrolinès CS keraminès šukès diferencinès terminès analizès tyrimai (3.19 pav.) parodè, kad pirmas endoterminis efektas vyksta $98^{\circ} \mathrm{C}$ temperatūroje, masès nuostoliai sudaro $0,8 \%$. Šis endoterminis efektas susijęs su chemiškai nesurišto vandens pašalinimu, nes džiovinama CS formavimo mase netenka drègmès. Toliau vyksta staigus egzoterminis efektas, kurio maksimumas pasiekiamas $\sim 323{ }^{\circ} \mathrm{C}$ temperatūroje, masès nuostoliai sudaro $2,5 \%$. Šis efektas ịvyksta išdegant organinėms medžiagoms, esančioms molyje, kurio metu išsiskiria $\mathrm{CO}_{2}$, $\mathrm{H}_{2}$, vandens garai. $507{ }^{\circ} \mathrm{C}$ temperatūroje endoterminis efektas susijęs su tuo, kad atskyla chemiškai surištas vanduo, masės nuostoliai sudaro 3,7 \%.

Po dehidratacijos prasideda ir vyksta molio mineralų struktūros pokyčiai. $\mathrm{Fe}^{2+}$ difuzija ị dehidratuotą hidrožèručio kristalinę gardelę $700-800{ }^{\circ} \mathrm{C}$ temperatūroje amorfizuoja ši mineralą, suardo karbonatus. Endoterminis efektas vyksta $755^{\circ} \mathrm{C}$ temperatūroje, jo masès nuostoliai $-9,8 \%$. Vyksta molio mineralų kristalinès struktūros suardymas. Šio efekto metu skyla magnio ir kalcio karbonatai, vyksta naujų fazių užuomazgų (kalio aliumosilikatų, anortito) susidarymas.

Paprastai karbonatų skilimas prasideda $650{ }^{\circ} \mathrm{C}$ temperatūroje, o baigiasi $700{ }^{\circ} \mathrm{C}$ (magnio), $800{ }^{\circ} \mathrm{C}$ (kalcio) $-900{ }^{\circ} \mathrm{C}$ temperatūroje (Sadūnas, 1999). 800 $850{ }^{\circ} \mathrm{C}$ temperatūroje suyra hidrožèručio kristalo gardèle, vyksta naujų stikliškujų ir kristalinių fazių susidarymas. Kalcio ir magnio mišiniams reaguojant su molio mineralais, susidaro diopsidas. 


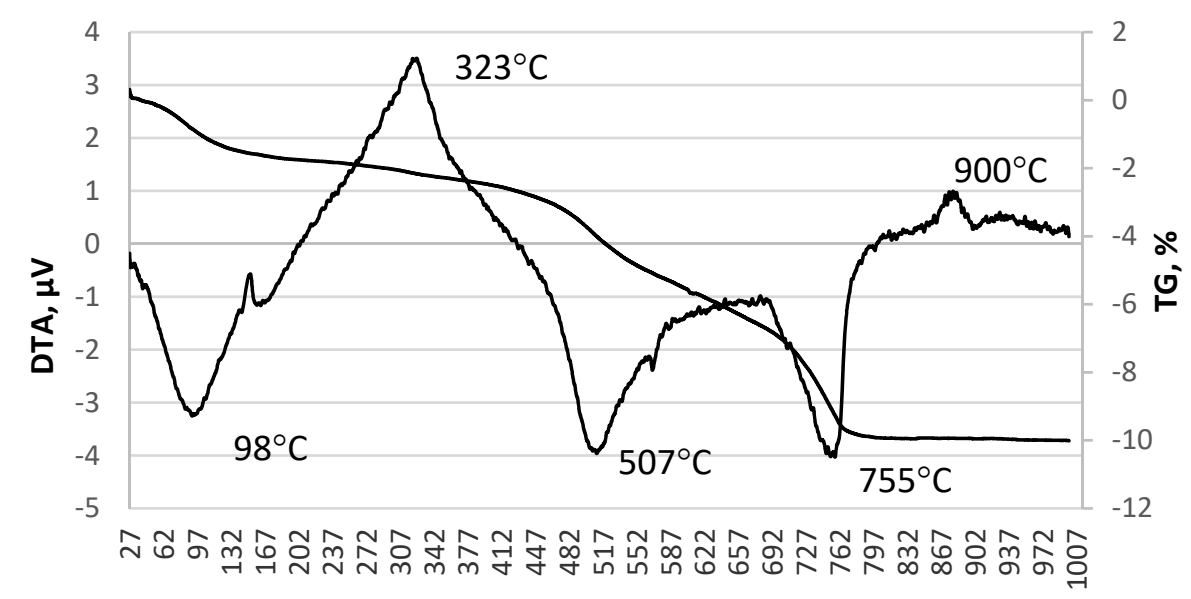

Temperatūra, ${ }^{\circ} \mathrm{C}$

3.19 pav. CS keraminès šukès termograma

Fig. 3.19. Thermogram of CS clay bricks

$900{ }^{\circ} \mathrm{C}$ temperatūroje vyksta egzoterminis efektas, susidarant naujoms kristalinèms fazèms (3.19 pav.): hematitui (turinčiam nedideli aktyvumą), gelenitui, aukštesnèse temperatūrose - anortitui. Stiklo fazè kinta nedaug, nes stiklingos medžiagos greitai sureaguoja su kitomis fazėmis, ypač su $\mathrm{Ca}^{2+}$. Kartu su anortito susidarymu vyksta špinelio kristalizacija, dèl to gali mažèti stikliškosios fazès ir diopsido kiekis.

Palyginus kontrolinių bandinių (CS keraminès šukès) ir bandinių su LP (FA 2,5) bei VLP (FAW 2,5 ir FAW 7,5) termografinès analizès rezultatus matoma, kad nagrinejjami priedai nedaro pastebimos įtakos chemiškai nesurišto vandens pašalinimui ir molio mineralų dehidratacijos procesams (3.19-3.22 pav.). Tačiau pastebèta, kad 2,5 \% LP (3.20 pav.) ir 7,5 \% VLP (3.22 pav.) daro įtaką molyje esančių organinių medžiagų išdegimui ir kalcio bei magnio dekarbonizacijos procesams, trukdo hidrožèručio kristalinès gardèlès amorfizacijos procesams (analizuojamas reakcijos plotas po smailèmis).

Išdegant organinėms medžiagoms $\left(\approx 323-329^{\circ} \mathrm{C}\right.$ temperatūroje) FA 2,5, FAW 2,5-7,5 (3.20-3.22 pav.) šukèse, ne taip intensyviai išsiskiria $\mathrm{CO}_{2}, \mathrm{H}_{2}$, kitos dujos, vandens garai. Dujų difuzija ị bandinio išorę mažeja, dèl to bandinio viduje gali formuotis stambesnès poros, kurios gali daryti neigiamą įtaką bandinių fizikinèms ir mechaninèms savybėms bei ilgaamžiškumui. 


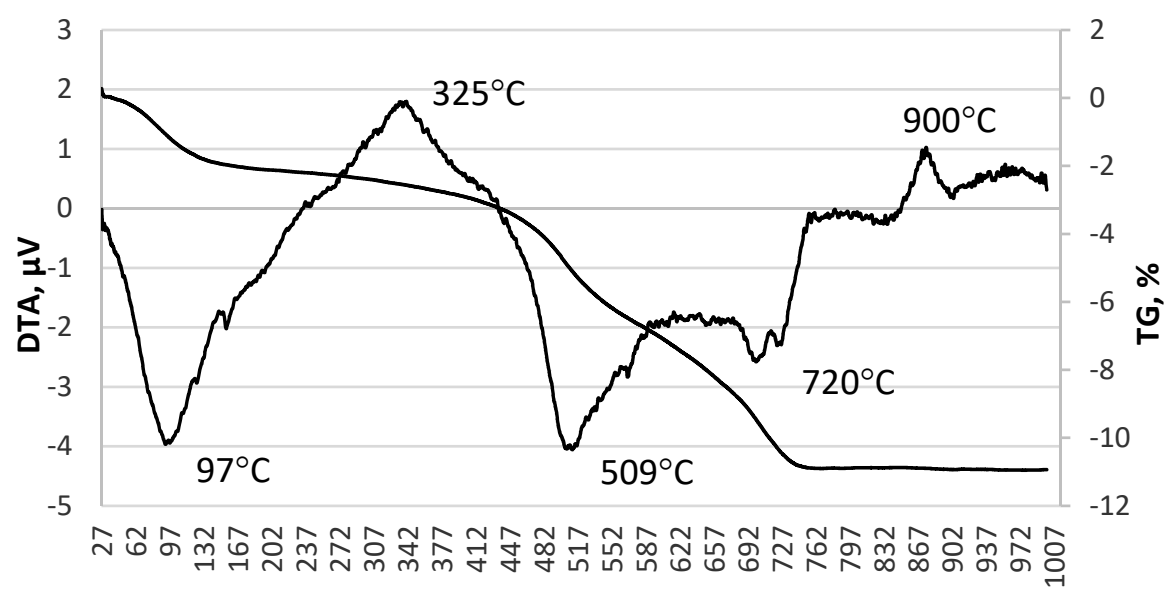

Temperatūra, ${ }^{\circ} \mathrm{C}$

3.20 pav. FA 2,5 keraminès šukès termograma

Fig. 3.20. Thermogram of FA 2,5 clay bricks

FA 2,5 ir FAW 7,5 keraminių šukių endoterminių kreivių plotas $720-733{ }^{\circ} \mathrm{C}$ temperatūroje yra gerokai mažesnis, palyginti su CS keramine šuke, o tai rodo žymesnị keraminių gaminių dekarbonizacijos laipsnị ir daro įtaką naujų kristalinių fazių mažesniam susidarymui keraminèje šukèje. Susilpnèja molingụjų mineralų kristalinès struktūros ryšiai, kurie susiję su naujų junginių, tokių kaip anortitasalbitas, susidarymu. Ryškus temperatūros ir reakcijos ploto (3.20 pav. ir 3.22 pav.) sumažèjimas taip pat susijęs su sulfatų, esančių lakiuosiuose pelenuose, skilimu. Eliche-Quesada et al. (2017) mano, kad sulfatų skilimas daro ịtaką ne tik temperatūros pokyčiams, bet ịvyksta ir svorio sumažejimo pokyčiai. Kaip matoma iš pateiktų paveikslų, įdedant ị formavimo mases LP arba 7,5 \% VLP kiekị, svorio sumažėja iki $11 \%$, palyginus su kontroline keramine šuke, kurios svoris sumažèja $10 \%$.

Mažesnis, palyginus su CS keramine šuke, minètos endoterminės kreivès smailių plotas $\left(720-755^{\circ} \mathrm{C}\right.$ temperatūroje) taip pat rodo, kad nagrinėjami priedai daro poveikị keraminių šukių mineralinès struktūros naujų ir pradinių fazių, tokių kaip gelenitas, o vèliau termodinamiškai stabilaus anortito susidarymui. Kad termodinamiškai stabilios fazès - anortito, keraminèje šukèje gerokai sumažèja, patvirtina toliau atlikti mechaniniai keraminių šukių tyrimai. Taip pat literatūroje rasti ir paminèti rezultatai (Mao et al., 2016; Tang et al., 2010, 2014; Lu et al., 2012, 2015) rodo, kad tokių priedų kiekis ir jų užterštumas sunkiaisiais metalais daro neigiamą įtaką naujų termodinamiškai stabilių mineralų susidarymui. 


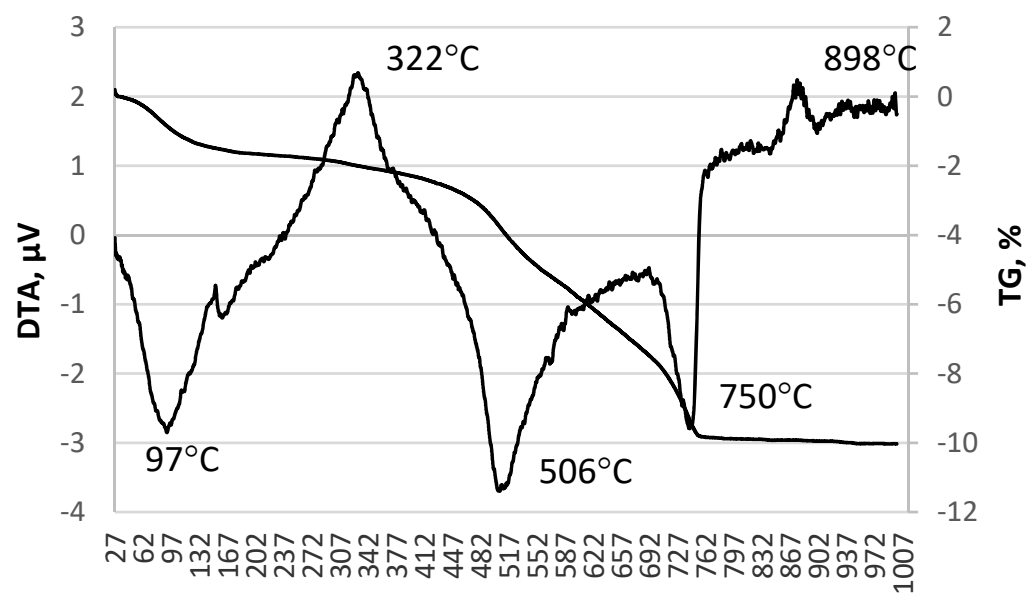

Temperatūra, ${ }^{\circ} \mathrm{C}$

3.21 pav. FAW 2,5 keraminès šukès termograma

Fig. 3.21. Thermogram of FAW 2,5 clay bricks

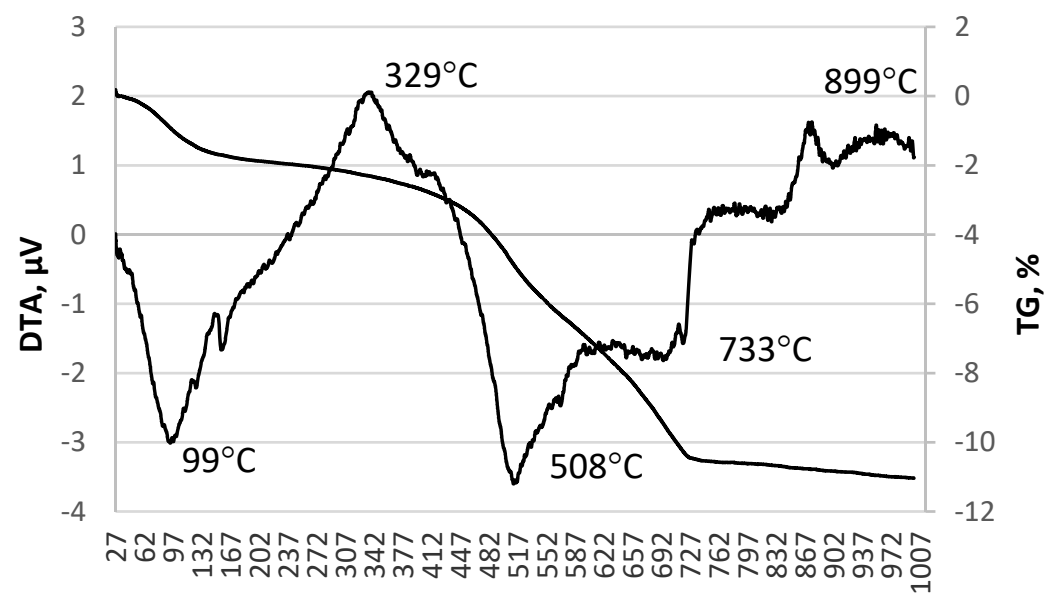

Temperatūra, ${ }^{\circ} \mathrm{C}$

3.22 pav. FAW 7,5 keraminès šukès termograma

Fig. 3.22. Thermogram of FAW 7,5 clay bricks

Teigiama, kad pirminių junginių susidarymui (pvz., gelenitui, o vèliau, esant aukštesnèms temperatūroms, anortitui-albitui (Павлов et al., 1977) arba tiesiogiai anortitui, špineliui, diopsidui) daro įtaką ne tik molio ir priedų pradinè sudètis, bet 
ir jų komponentų aktyvumo laipsnis. Aktyvumą gali mažinti ir prieš tai įvykęs dehidratacijos procesas, nes su tuo susijęs fazių savitasis paviršius. Žinoma, kad naujų fazių susidarymui ịtaką daro skirtingi kinetiniai aspektai, atsirandantys dèl pradinių komponentų sudèties skirtumų, taip pat dèl jų skirtingo užterštumo priemaišomis, kurios gali paveikti pradinių medžiagų aktyvumo laipsnị. Lakiưjų pelenų dalelès yra užterštos sunkiưjų metalų, chloridų, sulfatų priemaišų dalelèmis (1.6 pav.), o tai mažina jų aktyvumo bei pradinių molio mineralų aktyvumo laipsni. Todèl mažesnis anortito mineralo kiekio keraminèje šukèje susidarymas gali daryti neigiamą įtaką keraminè šukès stipruminèms savybėms.

Vykstant egzoterminiams procesams, užfiksuotiems maždaug $900{ }^{\circ} \mathrm{C}$ temperatūroje, ryškèja visų nagrinèjamų keraminių šukių mineralų kristalizacijos laipsnio nedideli skirtumai. Taip pat šioje ir aukštesnejje temperatūroje silpnejja stabilios skystosios fazès kiekio didejjimas. Chen et al. (2012) teigia, kad aukštesnejje nei $950{ }^{\circ} \mathrm{C}$ temperatūroje kalio ir natrio chloridai, esantys lakiuosiuose pelenuose, garuoja ir LP gali netekti apie $10 \%$ svorio. Šis pastebejimas taip pat prisideda prie didesnio keraminių šukių su LP ir VLP svorio netekimo.

\subsubsection{Keraminių šukių su lakiaisiais pelenais toksiškumo ivertinimas}

Siekiant imobilizuoti/užrakinti sunkiuosius metalus, esančius komunalinių deginimo atliekų lakiuosiuose pelenuose, ir taip sumažinti sunkiụjų metalų išplovimo iš keraminių šukių galimybes, statybinès keramikos gaminiai paprastai deginami aukštose $950-1150^{\circ} \mathrm{C}$ temperatūrose. Dažnai kuo aukštesnè degimo temperatūra, tuo efektyvesnès yra termodinaminès reakcijos, dèl kurių susidaro netirpūs vandenyje junginiai (Dondi et al., 2002), taip pat pakankamas skystosios fazės kiekis.

Principinè lakiujų pelenų formavimo masėse užrakinimo bei keraminèje šukeje imobilizavimo schema pateikta 3.23 paveiksle.

Žinoma, kad molis turi didelę katijonų mainų gebą (sunkiųjų metalų sorbciją). Molio dalelès, turedamos neigiamajjị krūvị, sulaiko teigiamai ịkrautus metalų jonus (Cation Exchange Capacity, 2007). Pagrindinis darbe naudojamo molio mineralų sluoksniavimosi tipas - 2:1, t. y. du silicio tetraedro $\left(\mathrm{Si}_{2} \mathrm{O}_{5}\right)$ sluoksnius apsupa vienas aliuminio oktaedro $\mathrm{Al}_{2} \mathrm{O}_{4}(\mathrm{OH})_{2}$ sluoksnis. Silpnos van der Walso jègos egzistuoja tarp dviejų vienetų ir cheminès medžiagos, t. y. sunkiưjų metalu dalelès gali lengvai patekti ị tarpsluoksnius, kuriuose yra imobilizuojamos.

Formuojant gaminius, tarp sausų susijungusių molingụjų dalelių įsiskverbia vandens molekulès ir adsorbuojasi ant dalelių paviršiaus, sudarydamos ploną vandens sluoksnị, dèl to molingujų dalelių tūris didejja, o dauguma lakiųu pelenų dalelių tarsi užrakinamos tarp molingųjų dalelių (3.23 pav., a).

Degant suformuotus gaminius aukštoje temperatūroje, dažniausiai pasireiškia skystafazis sukepimas (Sadūnas, 1999). Tarp dviejų arti išsidèsčiusių molingưju 
dalelių atsiranda tarpsluoksninis drèkinantis linzès formos skystis (skystoji fazè), kuriame atsiranda viršslègis. Slègis veikia skysčio masès pernešimą iš tarpgrūdelinio kristalo zonos, dèl to grūdeliai suarteja, lakiųu pelenų dalelès imobilizuotos/užrakintos tarp priartėjusių molingujų dalelių, o keraminè šukẻ susitraukia (3.23 pav., b).

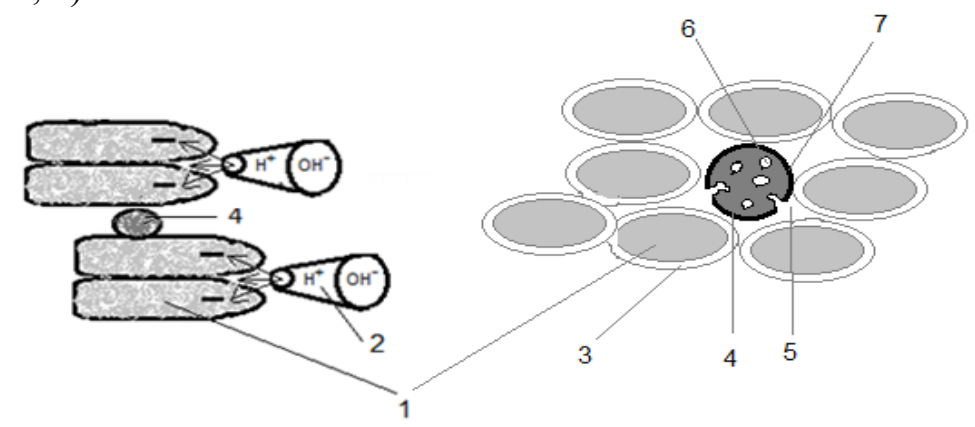

a)

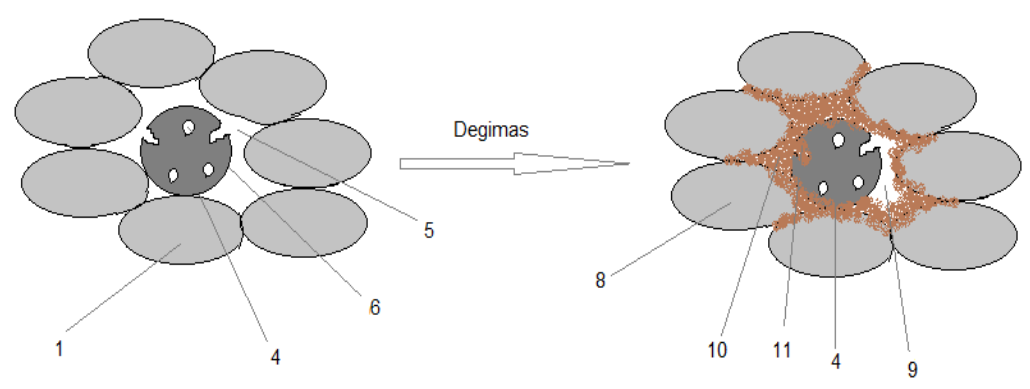

b)

3.23 pav. Keraminių šukių su lakiaisiais pelenais, lakiujų pelenų dalelių užrakinimo formavimo masejje principinè schema (a); lakiưjų pelenų dalelių imobilizavimo keraminėje šukèje schema (b): 1 - susijungusios molingosios dalelès; 2 - dipolinė vandens molekulè; 3 - adsorbcinis vandens ant molio dalelès sluoksnis; 4 - lakiujų pelenų dalelès; 5 - poros tarp molio dalelių ir tarp molio ir lakiuju pelenų dalelių; 6 - lakiujų pelenų poros; 7 - vandens ant lakiujjų pelenų dalelių sluoksnis; 8 - išdegta molio dalelè; 9 - poros (tarp molio dalelès ir lakiụjų pelenų) keraminèje šukèje; 10 skystoji fazė; 11 - skystaja faze užpildytos poros

Fig. 3.23. Clay bricks with fly ash, schematic diagram of the locking of fly ash particles in the mass formation (a); scheme of immobilization of fly ash particles in a clay brick: 1 - combined clay particles; 2 - dipole water molecule; 3 - adsorption layer of water on clay particles; 4 - fly ash particles; 5 - pairs between clay particles and between clay and fly ash particles; 6 - pores of fly ash; 7 - layer of water on particles of fly ash; 8 - burnt clay particle; 9 - pores (between clay particles and fly ash) in a clay brick; 10 - liquid phase; 11 - pores filled with liquid phase 
Tačiau keraminèje šukèje degimo metu gali atsirasti ịvairių defektinių vietu ar skystosios fazès kiekis gali būti nepakankamas, kad visos lakiujų pelenų dalelès būtų saugiai užrakinamos keraminèje matricoje (3.23 pav., b). Todèl turi būti atlikti pavojingưjų metalų išsiplovimo tyrimai, ịvertinantys ekologinị minèto priedo naudojimo aspektą, t. y. kad sunkieji metalai išsiplautų i aplinką minimaliai bei neviršytų galiojančiame normatyviniame dokumente (2003/33/EC) nurodytų ribinių verčių.

Atlikti sunkiujų metalų išsiplovimo iš keraminių šukių su LP tyrimai parodė (3.24 pav.), kad nustatytos $\mathrm{Cu}, \mathrm{Cd}, \mathrm{Pb}, \mathrm{Zn}$ metalų išsiplovimo vertès neviršija galiojančių normatyvinių dokumentų inertinių atliekų išsiplovimo ribinių verčių pagal 2003/33/EC reikalavimą. Nustatyta, kad įdedant i formavimo mases VLP ir išdegant jas $1000{ }^{\circ} \mathrm{C}$ temperatūroje, iš keraminių šukių (FAW 2,5; FAW 5,0; FAW 7,5) minètų išplautų metalų vertès yra gerokai mažesnès nei iš keraminių šukių, kuriose buvo naudoti LP (FA 2,5; FA 5,0; FA 7,5).

Atlikti sunkiujų metalų išsiplovimo iš keraminių šukių su LP ir VLP tyrimai parodè, kad, keraminèje šukèje didèjant lakiujų pelenų kiekiui, sunkiųjų metalų, chloridų bei sulfatų išsiplovimo iš nagrinejjamų keraminių šukių koncentracijos didèja. Pavyzdžiui, ịdejus ị keraminę šukę 7,5 \% VLP kiekį (FAW 7,5 keraminè šukè), $\mathrm{Pb}$ išsiplovimo iš keraminès šukès koncentracija padidejo 2,2 karto, lyginant su kontroline keramine šuke, net 1,4 karto padidejo $\mathrm{Cu}, 1,8$ karto $-\mathrm{Zn}$ ir 4,3 karto - Cr išsiplovimo koncentracijos. Taip pat 10,3 karto padidejjo sulfatu ir 1,5 karto chloridų išsiplovimo koncentracijos. İdedant ị keraminę šukę 7,5 \% LP kiekị (FA 7,5 keraminè šukè), Pb išsiplovimo iš keraminès šukès koncentracija padidèjo 3,3 karto, palyginti su kontroline keramine šuke, net 3,2 karto padidejjo $\mathrm{Cu}, 2,5$ karto $\mathrm{Zn}$ ir 10,6 karto $\mathrm{Cr}$ išsiplovimo koncentracijos. Taip pat 20,4 karto padidejo sulfatų ir 3,9 karto - chloridų išsiplovimo koncentracijos.

Nustatyta, kad įdejjus ị keraminę šukę 5,0\% ir didesnị LP kiekị, iš jų išsiplaunamo chromo ir nikelio kiekis, taip pat išplaunamų chloridų bei sulfatų kiekiai viršija inertinių atliekų išsiplovimo ribines vertes. Nors išsiplaunamų $\mathrm{Cr}$ ir Ni bei chloridų ir sulfatų kiekiai nepavojingųjų atliekų ribinių verčių neviršija, tačiau, atsižvelgus ị tai, kad 5,0\% ir didesnis LP kiekis neigiamai veikia keraminių bandinių vizualinę ir estetinę kokybę (3.2.2 poskyris), ant bandinių atsiranda išsūdų, nuspręsta, kad toliau bus tiriamos tik FA 2,5, FAW 2,5, FAW 5 ir FAW 7,5 keraminès šukès.

Nustatyta, kad nagrinėjamu keraminiu šukiu su LP ir VLP, pH ir savitojo elektrinio laidumo vertès didèja, ịdedant didesnị LP ar VLP kiekị (3.4 lentelè). Padidejusios $\mathrm{pH}$ ir Sel vertès rodo, kad padidejo $\mathrm{Ca}^{2+}, \mathrm{K}^{+}, \mathrm{Na}^{+}$kiekiai, sunkiųjų metalų, tokių kaip $\mathrm{Cd}^{2+}, \mathrm{Cr}^{3+}, \mathrm{Cu}^{2+}, \mathrm{Pb}^{2+}, \mathrm{Zn}^{2+}$ ir anijonų $\mathrm{Cl}^{-}$ir $\mathrm{SO}_{4}{ }^{2-}$ koncentracijos išplovimo tirpale. Tai reiškia, kad minètų metalų jonų ir anijonų kiekis keraminejje šukèje didejja, ką patvirtina sunkiųjų metalų išsiplovimo tyrimai ir keraminių šukių struktūros analizė (3.24 pav.). 


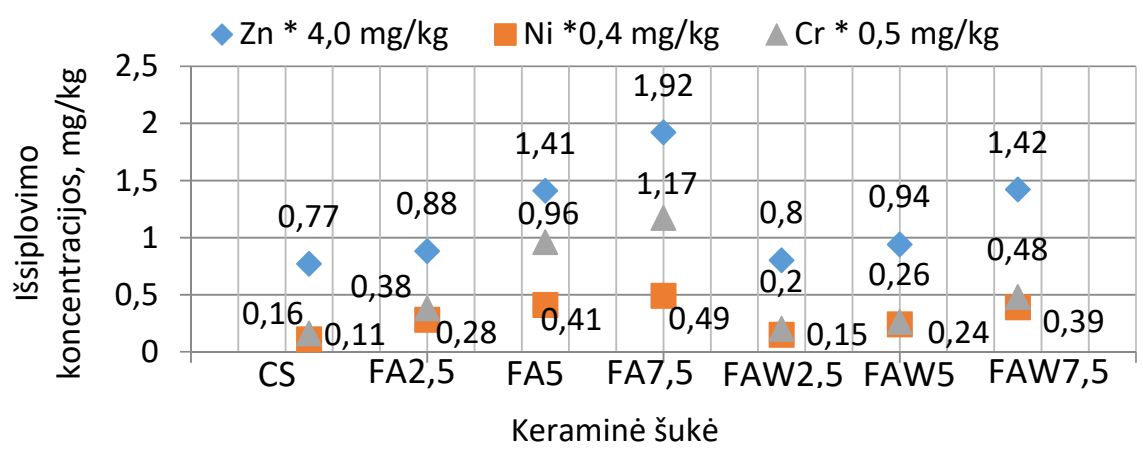

a)

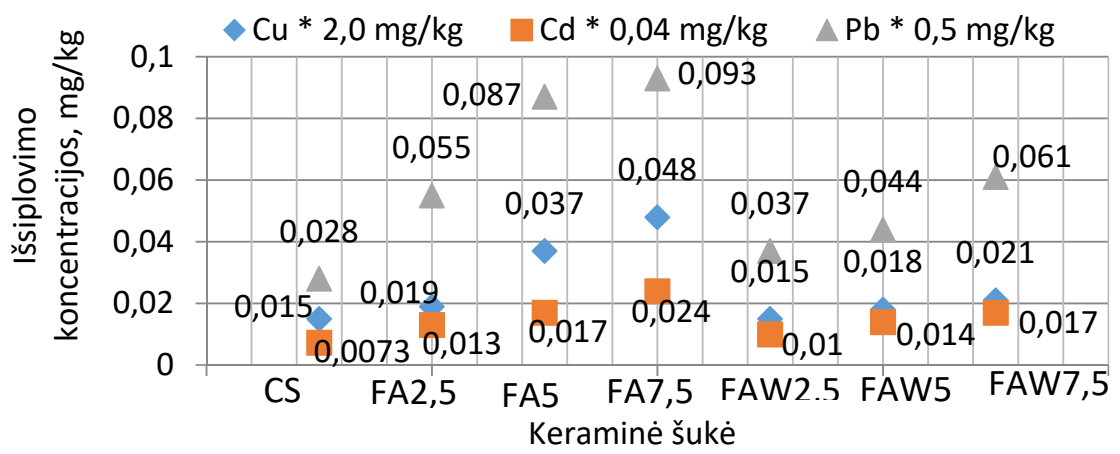

b)

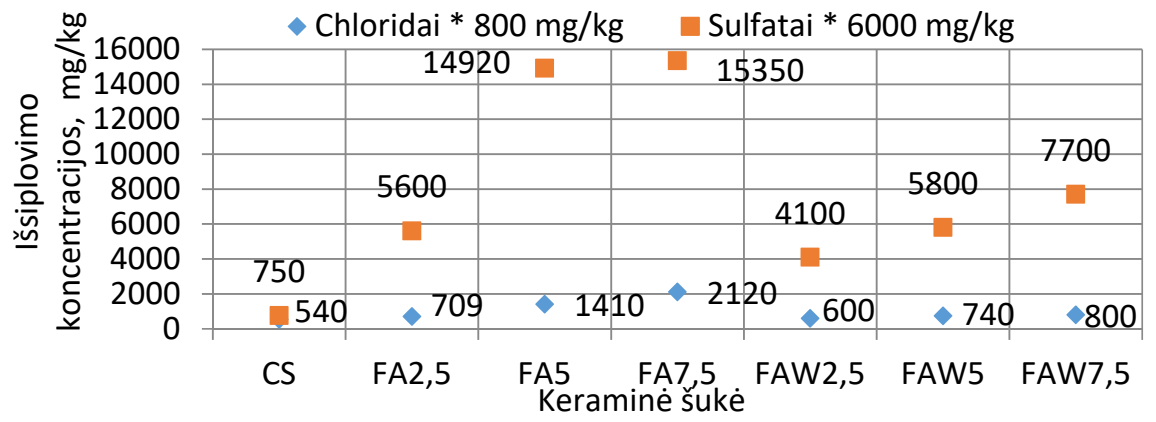

c)

3.24 pav. Keraminès šukès su lakiaisiais ir vandeniu apdorotais lakiaisiais pelenais sunkiųjų metalų, chloridų bei sulfatų išsiplovimo rezultatai: a) $\mathrm{Zn}, \mathrm{Ni}, \mathrm{Cr}$ išsiplovimo koncentracijos; b) $\mathrm{Cu}, \mathrm{Cd}, \mathrm{Pb}$ išsiplovimo koncentracijos; c) chloridų ir sulfatų išsiplovimo koncentracijos (*pažymètos ribinès koncentracijos pagal 2003/33/EC)

Fig. 3.24. Leaching results of clay bricks with LP and VLP heavy metals, chlorides and sulphates: a) $\mathrm{Zn}, \mathrm{Ni}$, Cr leaching concentrations; b) $\mathrm{Cu}, \mathrm{Cd}$, Pb leaching concentrations; c) chlorides and sulfates leaching concentrations (*marked concentration limits according to $2003 / 33 / \mathrm{EC}$ ) 
Reikia pabrèžti, kad išplovimo bandymų rezultatai, pateikti 3.24 paveiksle, yra nagrinėjamų sutrupintų bandinių gauti rezultatai. Todèl galima prognozuoti, kad iš nesutrupintų bandinių išsiplovimo rezultatų vertės bus kur kas mažesnès, ką patvirtina ir kitų autorių atlikti darbai (Aubert et al., 2007). Nesutrupintų bandinių tyrimas leidžia įvertinti gautų degtų bandinių su atliekiniais priedais poveikị aplinkai tik gaminių naudojimo laikotarpiui. Sutrupintų bandinių tyrimo rezultatai parodo, kas atsitiks su nagrinèjama medžiaga jos gyvavimo ciklo pabaigoje, t. y. kai statybiné medžiaga pati taps atlieka ir, pavyzdžiui, bus šalinama ị sąvartynus arba pakartotinai naudojama kitų statybinių produktų gamyboje.

3.4 lentelè. Keraminių šukių su lakiaisiais ir vandeniu apdorotais lakiaisiais pelenais $\mathrm{pH}$ ir Sel rezultatai

Table 3.4. $\mathrm{pH}$ and Sel results of clay bricks with fly ash and water-treated fly ash

\begin{tabular}{|l|l|l|l|l|l|l|l|}
\hline \multirow{2}{*}{$\mathrm{pH}$ ir Sel } & \multicolumn{6}{|l|}{ Keraminės šukės (pH ir Sel reikšmės) } \\
\cline { 2 - 8 } & CS & $\begin{array}{l}\text { FA } \\
2,5\end{array}$ & $\begin{array}{l}\text { FA } \\
5,0\end{array}$ & $\begin{array}{l}\text { FA } \\
7,5\end{array}$ & $\begin{array}{l}\text { FAW } \\
2,5\end{array}$ & $\begin{array}{l}\text { FAW } \\
5,0\end{array}$ & $\begin{array}{l}\text { FAW } \\
7,5\end{array}$ \\
\hline $\mathrm{pH}$ & 7,53 & 8,12 & 8,53 & 8,9 & 8,0 & 8,14 & 8,34 \\
\hline $\mathrm{Sel}, \mu \mathrm{S} / \mathrm{cm}$ & 355 & 1160 & 1488 & 1887 & 986 & 1254 & 1506 \\
\hline
\end{tabular}

Kaip matoma iš pateiktų tyrimų rezultatų, iš keraminių šukių FA 2,5, FAW 2,5-7,5 išplautų sunkiųjų metalų, chloridų ir sulfatų kiekiai neviršija inertinių atliekų ribinių verčių, todèl gyvavimo ciklo pabaigoje saugiai gali būti šalinami sąvartynuose arba naudojami kitų statybinių medžiagų gamyboje.

Siekiant ịvertinti keraminių šukių radioaktyvumo koncentraciją, buvo atlikti bandinių radiaciniai matavimai. Nustatyta (3.5 lentelè), kad degtuose bandiniuose su LP ir VLP randama gamtinių radioaktyvių nuklidų, tokių kaip radioaktyviojo kalio cheminio elemento izotopas bei radioaktyviojo radžio ir torio cheminių elementų nuklidų. Nustatytų gamtinių radionuklidų tūrinis aktyvumas nekelia pavojaus žmonių sveikatai ir aplinkai. Tai natūralus radiacinis fonas, kurị spinduliuoja radioaktyviosios uolienos.

Paprastai molyje yra gana dideli gamtinės kilmès radionuklidų savitieji aktyvumai. Tai susiję su tuo, kad gamtinès kilmès radionuklidai yra absorbuojami molio dalelių. Taip pat bandiniuose su LP ir VLP aptiktas radioaktyvusis nuklidas Cs-137. Aišku, kad dirbtinès kilmès radionuklido atsiradimą degtame bandinyje lemia lakiujų pelenų kiekis. Gauti duomenys rodo, kad radionuklidų kiekis skirtinguose molio gaminiuose gali skirtis. Visų tirtų bandinių nustatytos aktyvumo indekso vertès yra mažesnès už radionuklidų koncentracijos lygị, kurị leidžia ES ir Lietuvos normos (HN 85:2011, Nr. V-890). 
3.5 lentelè. Keraminių šukių su lakiaisiais ir vandeniu apdorotais lakiaisiais pelenais radioaktyvumo koncentracijos matavimai

Table 3.5. Radioactivity concentration measurements of clay bricks with fly ash and water-treated fly ash

\begin{tabular}{|l|l|l|l|l|l|l|l|}
\hline \multirow{2}{*}{$\begin{array}{l}\text { Gamtiniai } \\
\text { radionukli- } \\
\text { dai ir ra- } \\
\text { dioaktyvus } \\
\text { nuklidas }\end{array}$} & \multicolumn{6}{|l|}{ Keraminès šukès (savitasis aktyvumas, $\mathrm{Bq} \cdot \mathrm{kg}^{-1}$ ) } \\
\cline { 2 - 8 } & CS & FA 2,5 & FA 5,0 & FA 7,5 & FAW 2,5 & FAW 5,0 & FAW 7,5 \\
\hline K-40 & $\begin{array}{l}710 \\
\pm 12\end{array}$ & $722 \pm 17$ & $721 \pm 15$ & $796 \pm 19$ & $716 \pm 10$ & $712 \pm 13$ & $720 \pm 14$ \\
\hline Ra-226 & $\begin{array}{l}40 \pm \\
2\end{array}$ & $46 \pm 4$ & $41 \pm 3$ & $49 \pm 2$ & $45 \pm 3$ & $42 \pm 2$ & $47 \pm 2$ \\
\hline Th-232 & $\begin{array}{l}38 \pm \\
2\end{array}$ & $37 \pm 2$ & $41 \pm 3$ & $44 \pm 4$ & $37 \pm 3$ & $38 \pm 2$ & $40 \pm 2$ \\
\hline Cs-137 & - & 2,1 & 2,2 & 2,4 & 2,1 & 2,1 & 2,2 \\
\hline
\end{tabular}

\subsubsection{Lakiụjų pelenụ ịtaka keraminių šukių savybėms ir struktūrai}

Ivvertinus komunalinių deginimo atliekų LP ir VLP poveikị keraminių šukių mineraloginei sudèčiai, estetinei gaminių kokybei ir atsižvelgiant ị sunkiụjų metalų iš keraminių šukių išsiplovimo tyrimus, siekiant užtikrinti saugų lakiụjų pelenų naudojimą statybinès keramikos dirbiniuose, toliau buvo tiriamos FA 2,5; FAW 2,5; FAW 5,0; FAW 7,5 keraminès šukès.

Nustatyta, kad LP ir VLP teigiamai veikia keraminių šukių susitraukimą po džiovinimo ir degimo (3.25 pav.). CS keraminès šukès susitraukimas po džiovinimo siekia $9,1 \%$, po degimo $1000{ }^{\circ} \mathrm{C}$ temperatūroje, išlaikant aukščiausioje degimo temperatūroje 1 val., $-11,2 \%$. Iddedant ị formavimo mases $2,5 \%$ LP ar VLP kieki, susitraukimas po džiovinimo sumažeja iki 8,3 \%. Didinant VLP formavimo masėse kieki nuo 5,0 \% iki 7,5 \%, susitraukimas po džiovinimo sumažèja atitinkamai iki 7,0 \% ir 6,4 \%. Susitraukimas po džiovinimo mažèja todèl, kad lakiųu pelenų dalelès suformuotame bandinyje sudaro dalelių karkasą, dèl kurio plastiškosios džiovinamo molio dalelès negali intensyviau artèti viena prie kitos. Lakiųuu pelenų neplastiškosios dalelès stabilizuoja džiovinimo procesą, nepaisant didejjančio vandens poreikio formavimo metu ( 2.4 lentelè). Išdegant formavimo mases $1000{ }^{\circ} \mathrm{C}$ temperatūroje su skirtingais LP ar VLP kiekiais bandinių defektų, pavyzdžiui išsipūtimo ar įtrūkimų, pastebèta nebuvo. Degimo metu lakiưjų pelenų dalelių tarp formavimo masèje esančių plastiškuju molio dalelių buvimas skatina atsirasti papildomų porų keraminejje šukeje. Molyje degimo metu atsiradęs skystosios fazès kiekis nèra pakankamas, kad ta porų struktūra būtų pilnai užpildyta, 
o molio dalelès galètų labiau per skystosios fazès terpę priartèti viena prie kitos, nes tarp plastiškujjų molio dalelių ir skystosios fazès yra dar neplastiškujjų lakiųjų pelenų dalelių. Dèl to mažèja bandinių su LP ar VLP susitraukimas po degimo ir didèja bandinių atvirasis poringumas (3.25 pav., 3.26 pav.).

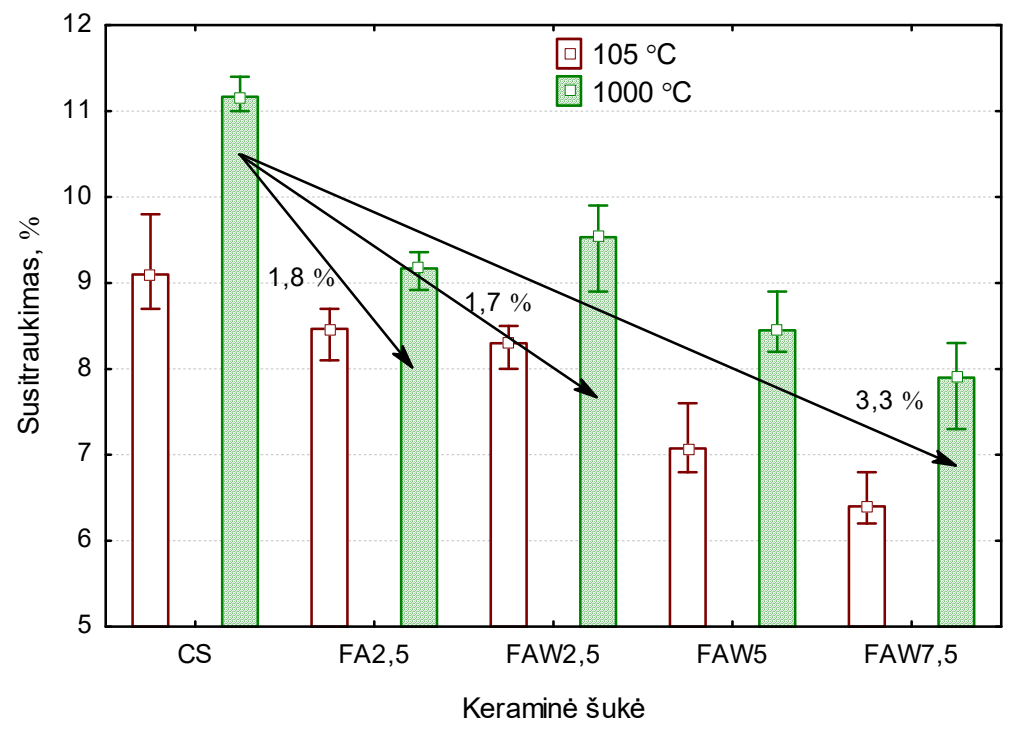

3.25 pav. Lakiujjų ir vandeniu apdorotų lakiųjų pelenų įtaka keraminių šukių susitraukimui, ( $\rightarrow$ pokytis (\%) lyginant su CS kontroline šuke)

Fig. 3.25. Influence of fly ash and water-treated fly ash on clay bricks shrinkage, $(\rightarrow$ change $(\%)$ compared to CS clay body)

Kontrolinès keraminès šukès be nagrinejjamo priedo (CS degta keraminè šukè) atvirasis poringumas siekia 18,0 \%. 2,5 \% LP keraminès šukès atviraji poringumą padidina iki $27,7 \%$, o 2,5 \% VLP - tik iki 20,6 \%. İdejjus didžiausią 7,5\% VLP kiekị, keraminès šukès atvirasis poringumas padideja iki 25,8 \%. Atvirasis poringumas apibūdina degtų bandinių struktūrą, charakterizuoja tą porų ir kapiliarų potencialą, kuris lengvai užsipildo vandeniu, todèl tarp atvirojo poringumo ir vandens įmirkio yra stipri koreliacija.

Atlikus degtų bandinių vandens įmirkio tyrimus, buvo nustatyta, kad 2,5\% LP keraminès šukès vandens įmirki padidina iki $15,3 \%$, o 2,5\% VLP - tik iki $11,7 \%$. Net ịdèjus didžiausią 7,5\% VLP kiekį, keraminès šukès vandens įmirkis yra mažesnis, nei įdejus 2,5 \% LP kiekị, ir siekia 14,5\%.

Nagrinëjamų keraminių šukių atvirojo poringumo ir vandens įmirkio priklausomybè pateikta 3.27 paveiksle. Akivaizdu, kad regresijos tiesè tinka, nes nustatytų reikšmių priklausomybė yra tiesinè, nors duomenyse yra išskirtinių reikšmių. 
Tačiau jie praktiškai nekeičia regresijos tiesès lygties koeficientų ịverčių. Todèl matoma, kad nagrinejjamų bandinių atvirasis poringumas $\left(W_{a}\right)$ priklauso nuo jų įmirkio $(W)$ pagal pateiktą tiesinę regresijos lygtį:

$$
W_{a}=3,37+1,54 \quad W, \% .
$$

Gautos lygties koreliacijos koeficientas $R=0,985$, determinacijos koeficien$\operatorname{tas} R^{2}=0,971$, standartinis nuokrypis $S_{e}=0,579 \%$.

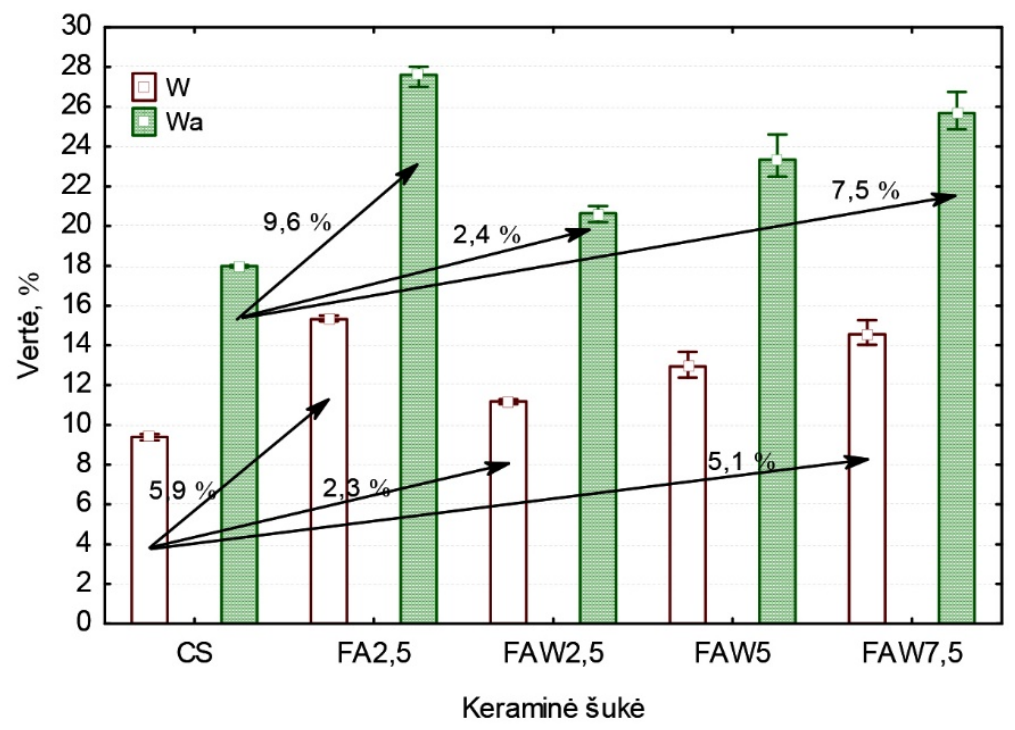

3.26 pav. Lakiųjų ir vandeniu apdorotų lakiujų pelenų įtaka keraminių šukių atvirajam poringumui $\left(W_{a}\right)$ ir vandens ịmirkiui $(W),(\rightarrow$ pokytis $(\%)$ lyginant su CS kontroline šuke)

Fig. 3.26. Influence of fly ash and water-treated fly ash on open porosity $\left(W_{a}\right)$ and water absorption $(W)$ of clay bricks, ( $\rightarrow$ change (\%) compared to CS clay body)

LP ir VLP mažina keraminių šukių tankị ir didina bendraji poringumą (3.28 pav.). LP keraminès šukès tankị sumažina $6,25 \%$ iki $1,8 \mathrm{~g} / \mathrm{cm}^{3}$, o bendrajj poringumą padidina iki $31,2 \%$, palyginus su CS keramine šuke. Geriausi rezultatai gauti įdèjus ị sistemas 2,5\% VLP kiekį. FAW 2,5 keraminès šukès tankis sumažejo $4,1 \%$ ir siekia $1,84 \mathrm{~g} / \mathrm{cm}^{3}$, o bendrasis poringumas padidejo iki $27,3 \%$. Toliau didinant formavimo masèse VLP kiekị, tankis mažeja, o bendrojo poringumo vertès dideja. FA 2,5 ir FAW 2,5, FAW 5 ir FAW 7,5 poringumų (atvirojo ir bendrojo) verčiu padidejjimui daro įtaką struktūroje susiformavusios papildomos atsitiktinès poringos ertmès, kurių atsiradimą lemia lakiụjų pelenų dalelių struktūra ir sudètis, daugiausia kalcio sulfato junginiai (3.16 pav.). 


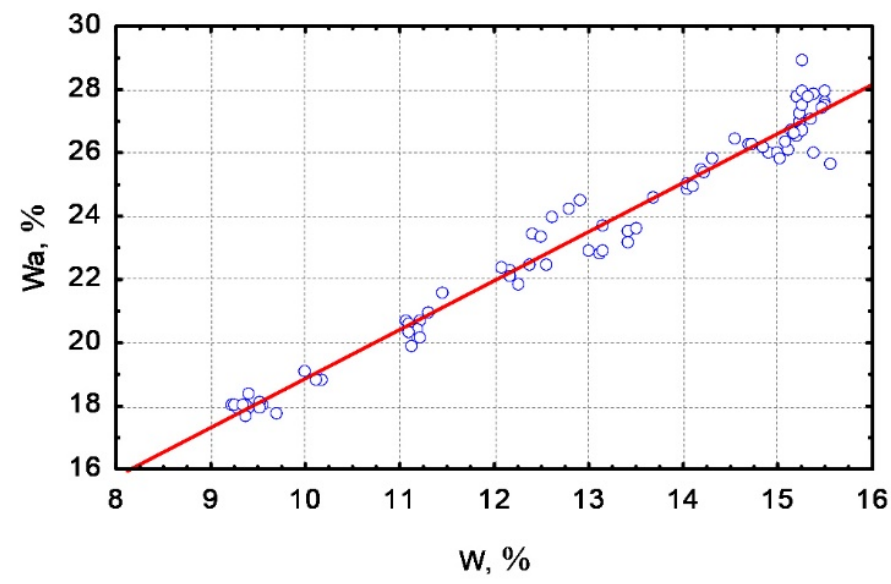

3.27 pav. Keraminių šukių su lakiaisiais ir vandeniu apdorotais lakiaisiais pelenais atvirojo poringumo $\left(W_{a}\right)$ ir vandens įmirkio $(W)$ priklausomybe

Fig. 3.27. Dependence of open porosity $\left(W_{a}\right)$ and water absorption $(W)$ of clay bricks with fly ash and water-treated fly ash

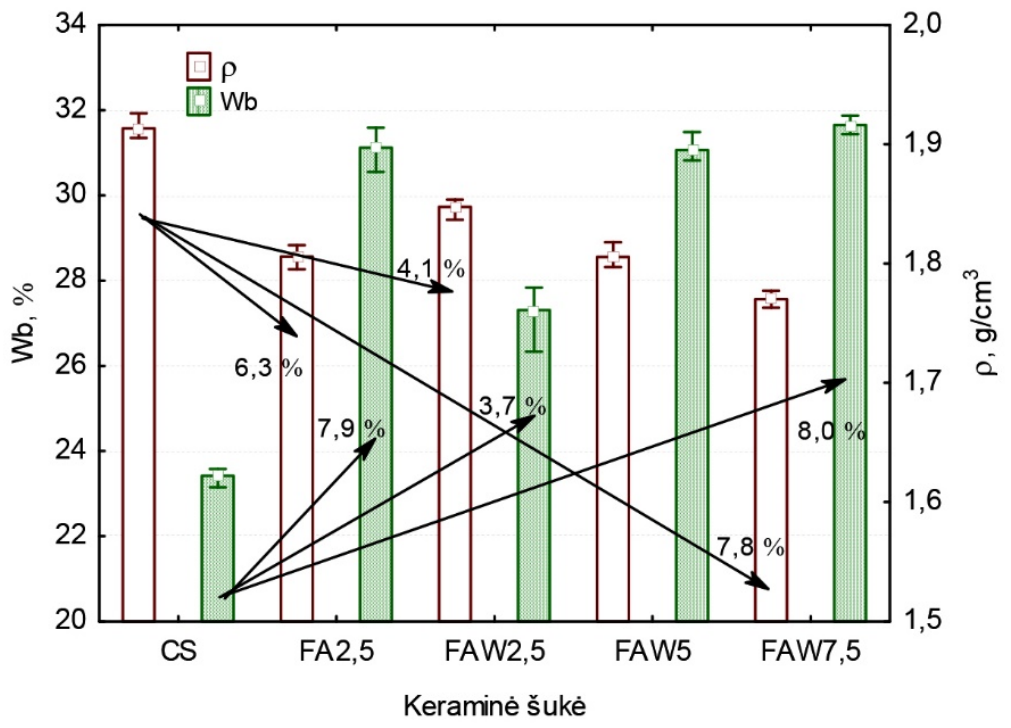

3.28 pav. Lakiujų ir vandeniu apdorotų lakiųjų pelenų ịtaka keraminių šukių tankiui $(\rho)$ ir bendrajam poringumui $\left(W_{b}\right),(\rightarrow$ pokytis $(\%)$ lyginant su CS kontroline šuke)

Fig. 3.28. Influence of fly ash and water-treated fly ash on clay bricks density $(\rho)$ and total porosity $\left(W_{b}\right),(\rightarrow$ change $(\%)$ compared to CS clay body) 
Sąlyginis porų ir kapiliarų sienelès storis nusako svarbią nagrinëjamo kūno struktūros ypatybę, kuri priklauso nuo degtų bandinių tankio ir poringumo. Nustatyta, kad ịdedant ị statybinès keramikos gaminius LP ir VLP ir mažejant keraminès šukès tankiui bei didejjant bendrajam poringumui, sąlyginis porų ir kapiliarų sienelès storis mažeja (3.29 pav.). Nagrinejjamų bandinių sąlyginis porų ir kapiliarų sienelių storis $(D)$ priklauso nuo jų bendrojo poringumo $\left(W_{b}\right)$ pagal pateiktą tiesinę regresijos lygtị:

$$
D=6,354-0,134 \quad W_{b} .
$$

Gautos lygties koreliacijos koeficientas $R=0,989$, determinacijos koeficien$\operatorname{tas} R^{2}=0,978$, standartinis nuokrypis $s_{e}=0,065 \%$.

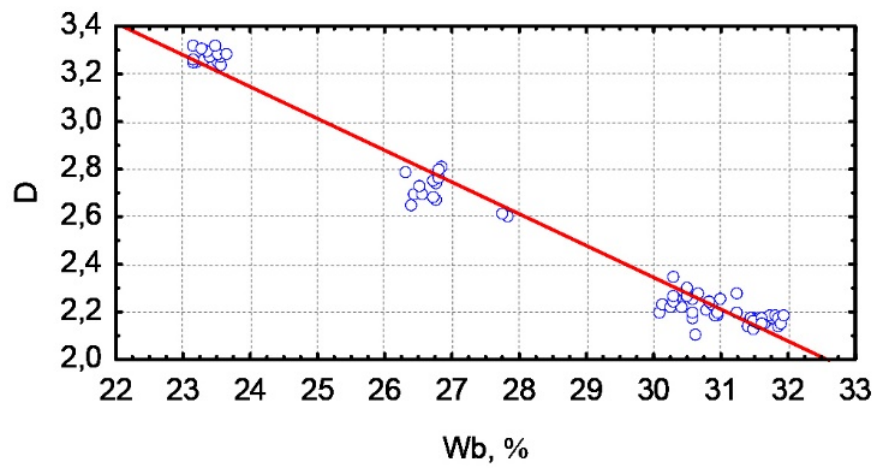

3.29 pav. Keraminių šukių su lakiaisiais ir vandeniu apdorotais lakiaisiais pelenais sąlyginiu porų ir kapiliarų sienelių storio $(D)$ ir bendrojo poringumo $\left(W_{b}\right)$ priklausomybè

Fig. 3.29. Clay bricks with fly ash and water-treated fly ash relative thickness of pore and capillary walls $(D)$ and total porosity $\left(W_{b}\right)$

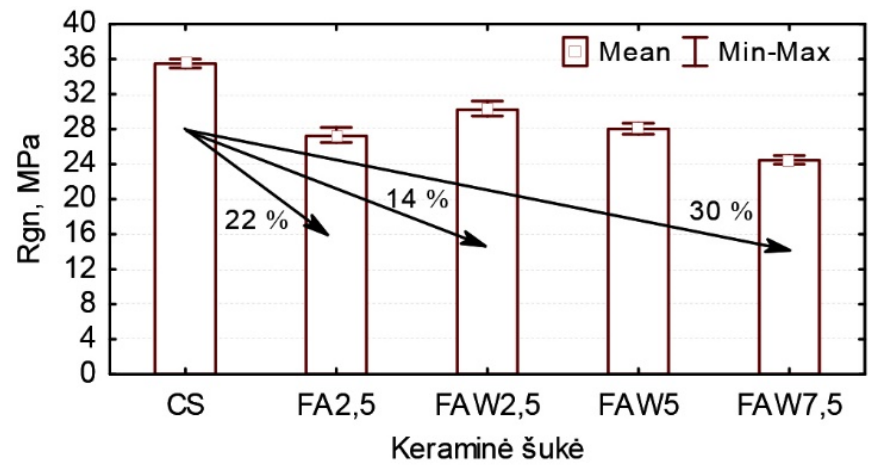

3.30 pav. Lakiujų ir vandeniu apdorotų lakiujų pelenų įtaka keraminių šukių gniuždymo stipriui $\left(R_{g n}\right),(\rightarrow$ pokytis $(\%)$ lyginant su CS kontroline šuke)

Fig. 3.30. Effect of fly ash and water-treated fly ash on compressive strength $\left(R_{g n}\right)$ of clay bricks, ( $\rightarrow$ change compared (\%) to CS clay body) 
CS keraminès šukès gniuždymo stipris siekia $35 \mathrm{MPa}$. LP ir VLP mažina degtų bandinių gniuždymo stiprị (3.30 pav.). 2,5\% LP keraminès šukès gniuždymo stiprị sumažina iki $27 \mathrm{MPa}$, o 2,5 \% VLP - iki $30 \mathrm{MPa}$. Didžiausias 7,5 \% VLP kiekis keraminès šukès gniuždymo stiprị sumažina iki $24 \mathrm{MPa}$.

\subsubsection{Lakiujų pelenų ịtaka keraminių šukių mikrostruktūrai}

Keraminių šukių su LP ir VLP tankio, gniuždymo stiprio, susitraukimo mažèjimą, vandens įmirkio ir poringumų padidèjimą lemia pasikeitusi bandinių struktūra, kuriai įtaką daro pokytis mikrostruktūros lygmeniu. Naudojami priedai daro įtaką mineralų formavimosi procesams degimo metu, keičia mineraloginę sudètį (3.123.15 pav.), o tai lemia bandinio mikrostruktūrą. Toliau atlikti tyrimai tai patvirtina.

CS mikrostruktūros tyrimai pateikti 3.31 pav., a. Kaip matoma, CS degtos keraminės šukès struktūra yra gana tanki, joje vyrauja nedidelis kiekis porų. Poros yra ovalios, jos tolygiai išsidėsčiusios po visą keraminę šukę ir yra didesnès nei 1,5-2 $\mu \mathrm{m}$. Koroch et al. (1998) nurodo, kad tik mažesnès nei 1,0-1,5 $\mu \mathrm{m}$ poros neigiamai veikia keraminių gaminių atsparumą šalčiui, nes jos negali atlaikyti užšalusio vandens slėgio, dẻl to keraminèje šukeje greičiau vyksta destrukcijos procesai.

Defektinių vietų arba įtrūkių degtų bandinių mikrostruktūroje nepastebèta, o tai reiškia, jog technologiniai degimo parametrai parinkti tinkamai, degimo metu susiformavęs skystosios fazès kiekis yra pakankamas, kad visa keraminès šukès matrica būtų užpildyta tolygiai.

İdedant ị formavimo mases LP, VLP ir išdegant $1000^{\circ} \mathrm{C}$ temperatūroje, bandinių mikrostruktūra keičiasi (3.31 pav., b-e). FA 2,5 degtų keraminių bandinių mikrostruktūroje vyrauja pailgos, mažesnès nei $1 \mu \mathrm{m}$ formos poros, pasiskirsčiusios po visą matricą. Porų kraštai labai nelygūs. Taip pat pastebimos labai smulkios $(\leq 0,5 \mu \mathrm{m})$ poros (3.31 pav., b). FAW 2,5 bandinių struktūroje porų akivaizdžiai yra mažiau nei FA 2,5 struktūroje, o skystosios fazès kiekis didesnis. Poros nedidelès, apvalesnès, didesnes nei $1 \mu \mathrm{m}$, matricos paviršius tankesnis (3.31 pav., c). Tačiau akivaizdu, jog susidariusios skystosios fazès kiekio nepakanka tam, kad būtų užpildyta dauguma porų. Matoma šiek tiek netolygi bandinių paviršiaus morfologija. Atlikus FAW 5 sistemos mikrostruktūros tyrimus, matoma gana tanki matrica, tačiau joje vyrauja pailgos tolygiai išsidèsčiusios poros, taip pat atsiranda ir pakankamai didelių $1,0-1,5 \mu \mathrm{m}$ apvalių porų (3.31 pav., d). FAW 7,5 mikrostruktūroje matoma, kad matrica tampa mažiau tanki, vyrauja didelès netaisyklingos formos poros, kurios yra atvirosios ir pereina ị pailgos formos $(1,0-2,0 \mu \mathrm{m})$ poras (3.31 pav., e). Žinoma (Sveda, 2001; Koroth et al., 1998; Cimmers et al., 2005), kad 1,0-1,5 $\mu \mathrm{m}$ poros neigiamai veikia keraminių gaminių ilgaamžiškumą. 


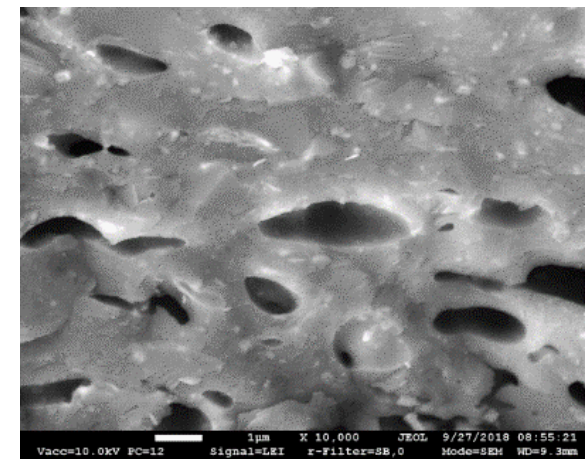

a)

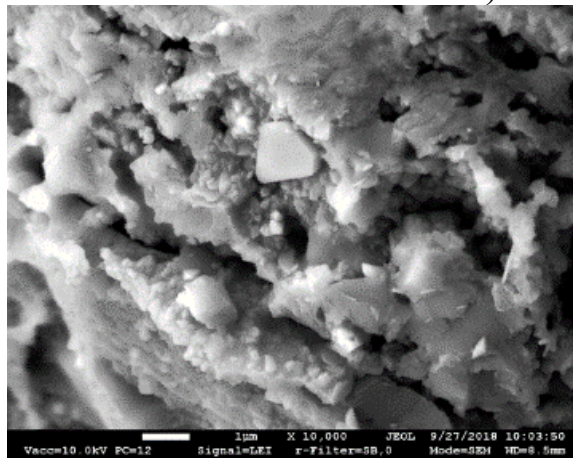

c)

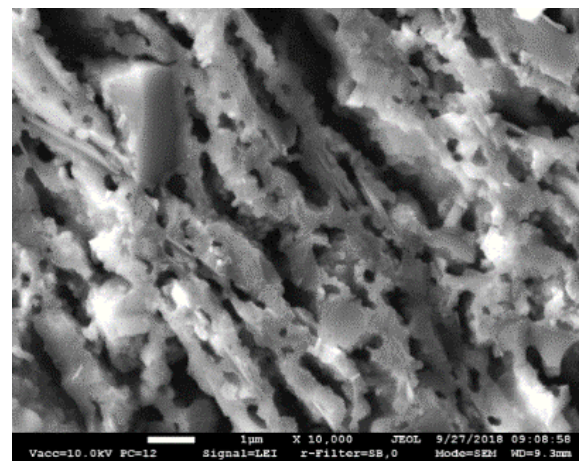

b)

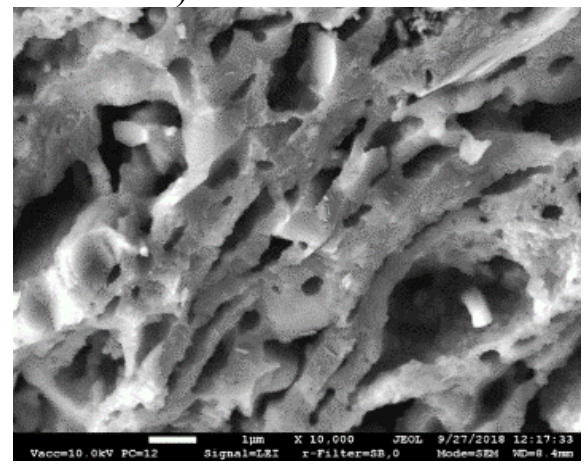

d)

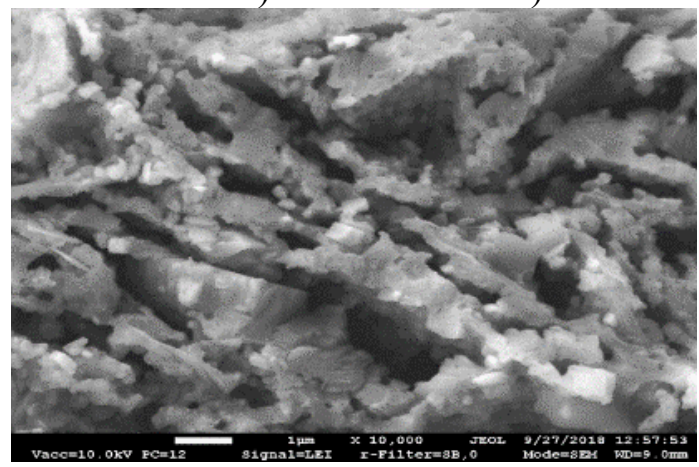

e)

3.31 pav. Keraminių šukių mikrostruktūra: a) CS; b) FA 2,5; c) FAW 2,5; d) FAW 5,0; e) FAW 7,5

Fig. 3.31. The microstructure of clay bricks: a) CS; b) FA 2.5; c) FAW 2.5; d) FAW 5.0; e) FAW 7.5 
Ivairių sulfatų, chloridu ir didelis $\mathrm{CaO}$ kiekis, esantis nagrinejjamuose prieduose, veikè keraminių šukių mikrostruktūrą, įdedant didesnį LP ar VLP kiekị. Keraminès sukès (susidarant sulfatams, garuojant chloridams, skylant $\mathrm{CaCO}_{3}$ $\sim 750{ }^{\circ} \mathrm{C}$ ) struktūra pasidaro poretesnè. Tą patvirtina ir Cao et al. (2017) atlikti moksliniai darbai, kai lengvujų užpildų gamyboje buvo naudojami pelenai, turintys dideli $\mathrm{CaO}$ kieki. Irodyta, kad didesnis pelenų kiekis lemia poringesnę gaminių struktūrą. Kiti autoriai (Eliche-Quesada et al., 2017) taip pat patvirtina, kad lakieji pelenai veikia keraminę šukę kaip papildomų porų formavimosi priedas. Chen et al. (2012) pabrèžia, $\mathrm{kad} 950{ }^{\circ} \mathrm{C}$ temperatūroje chloridų pašalinimo (garavimo) metu lakieji pelenai netenka apie $10 \%$ savo svorio, o pakeliant temperatūrą iki $1050{ }^{\circ} \mathrm{C}$, pelenai netenka net $23 \%$ savo svorio.

Pabrèžtina, kad, esant didesniam degtame bandinyje susiformavusios skystosios fazès kiekiui, difuziniai procesai jame vyksta lengviau. Gauti mikrostruktūros tyrimai koreliuoja su šių keraminių šukių gautais fizikinių ir mechaninių savybių rezultatais bei poringumo rodikliais.

CS sistemoje galima lengvai identifikuoti (EDS tyrimai) kvarco (1), hematito (2), diopsido (3) mineralus (3.32 pav.). Tai yra tie mineralai, kurie dažniausiai susidaro deginant tradicinę keraminę šukę. Diopsidas susidaro kalcio ir magnio mišiniams reaguojant su $\mathrm{SiO}_{2}$ ir $\mathrm{Al}_{2} \mathrm{O}_{3}$. Atlikti diopsido dalelès EDS tyrimai (3.32 pav., b) patvirtino, kad dalelę sudaro $\mathrm{O}-52,51 \%$; $\mathrm{Mg}-18,46 \%$; $\mathrm{Si}-$ $11,41 \% ; \mathrm{Ca}-9,13 \%$, kt. $-8,49 \%$. Hematito dalelę (3.32 pav., a ir c) sudaro $\mathrm{Fe}-$ $62,33 \% ; \mathrm{O}-30,61 \%$, kt. $-7,06 \%$.

Verta atkreipti dèmesį, kad tarp kvarco grūdelių ir amorfinès/skystosios fazès nèra įtrūkių (3.32 pav., a). Tai parodo, kad technologiniai degimo parametrai buvo parinkti tinkamai, o kvarco intervalo perejjimas $\beta \rightarrow \alpha$ laiko atžvilgiu yra pakankamas.

İdedant LP ir VLP, mikrostruktūroje papildomai identifikuojami kalcio sulfato mineralai. Atlikti mikrostruktūros EDS tyrimai patvirtino atliktus keraminių šukių su LP ir VLP mineraloginius tyrimus ir parodè, kad struktūroje randama $\mathrm{CaSO}_{4}$ mineralu (3.32 pav., d (4)).

Kalcio sulfato mineralai dažniausiai identifikuojami porose, tarp jų ir matricos nèra geros sąlyčio zonos, todèl šių mineralų atsiradimas didina bandinių poringumą (3.32 pav. d, e). Be to, kalcio sulfatai yra sunkiai suardomi net degant aukštų temperatūrų intervale. Kalcio sulfatas degant oksidacineje aplinkoje gali skilti tik esant maždaug $1230{ }^{\circ} \mathrm{C}$ temperatūrai. Atlikti EDS kalcio sulfato dalelès tyrimai parodè, kad dalelę sudaro $\mathrm{O}-54,68 \%, \mathrm{Ca}-24,86 \%, \mathrm{~S}-12,13 \%$ ir kt. $8,33 \%$ (3.32 pav., e). Taip pat $\mathrm{CaSO}_{4}$ mineralas turi gana didelị tūrị, kuris destrukciškai veikia keraminès šukès poru (jis dažniausiai formuojasi užpildydamas poras) sieneles, o tai lemia išdegto bandinio poringumą bei stiprumines savybes. 


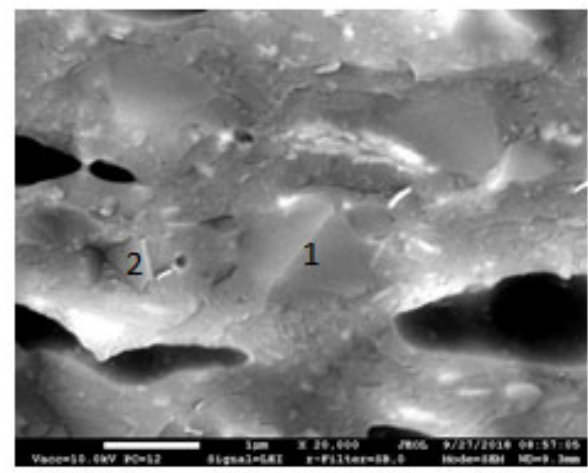

a)

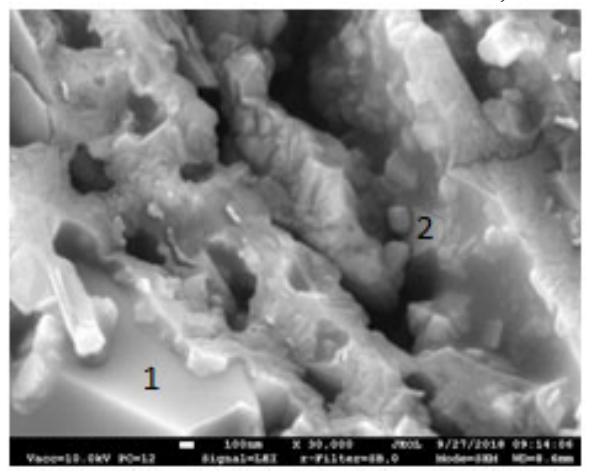

c)

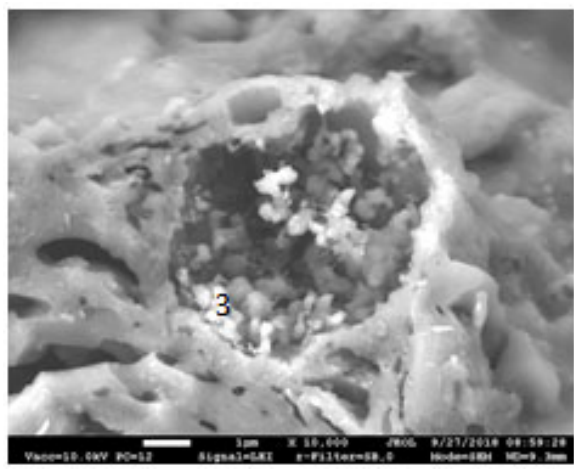

b)

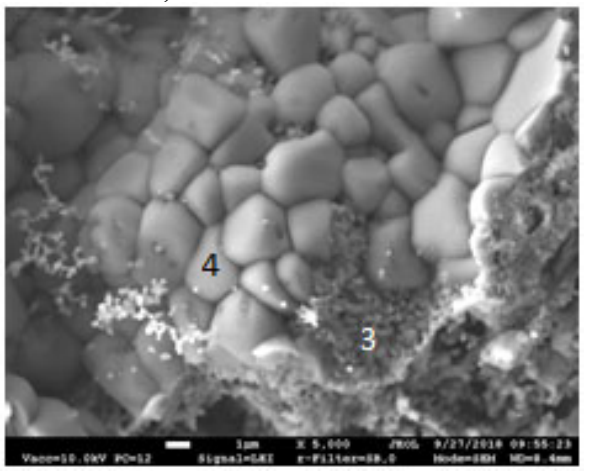

d)

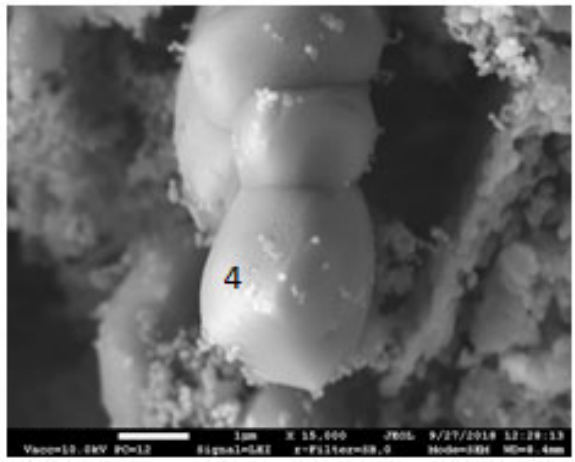

e)

3.32 pav. Keraminių šukių mikrostruktūra ir mineralų identifikavimas: a) ir b) - CS; c) ir d) - FA 2,5; e) FAW 2,5. Identifikuoti mineralai: 1 - kvarcas $\left(\mathrm{SiO}_{2}\right)$; 2 - hematitas $\left(\mathrm{Fe}_{2} \mathrm{O}_{3}\right) ; 3$ - diopsidas $\left(\mathrm{MgCaSi}_{2} \mathrm{O}_{6}\right) ; 4$ - kalcio sulfatas $\left(\mathrm{CaSO}_{4}\right)$

Fig. 3.32. The microstructure of clay bricks and identification of minerals: a) and b) - CS; c) and d) - FA 2.5; e) FAW 2.5. Identified minerals: 1 - quartz $\left(\mathrm{SiO}_{2}\right)$; 2 - hematite $\left(\mathrm{Fe}_{2} \mathrm{O}_{3}\right) ; 3$ - diopside $\left(\mathrm{MgCaSi}_{2} \mathrm{O}_{6}\right) ; 4$ - calcium sulfate $\left(\mathrm{CaSO}_{4}\right)$ 


\subsubsection{Keraminių šukių su lakiaisiais pelenais ilgaamžiškumo tyrimai}

Degti molio gaminiai, eksploatacijos metu Lietuvos ar kitų šiaurinių šalių sąlygomis cikliškai šaldomi bei atšildomi, yra veikiami užšaldymo ir atitirpinimo metu susidarančių apkrovų. Apkrovos dydis priklauso nuo formavimo, džiovinimo ir degimo metu susiformavusios struktūros, o medžiagos suirimą nulemia porų struktūra bei užpildymo vandeniu laipsnis. Prieš tai atlikti nagrinèjamų keraminių šukių tyrimai parodè, kad LP ar VLP keičia bandinių struktūrą (3.31 ir 3.32 pav.), didina atvirajị ir bendraji poringumą bei vandens įmirkị (3.26 ir 3.28 pav.).

Atliekant tyrimus visų pirma buvo ịvertintas degtų bandinių porų ir kapiliaru įsotinimo koeficientas $\left(K_{i s}\right)$, kuris netiesioginiu būdu ịvertina bandinių atsparumą šalčiui. Nustatyta, kad CS keraminių šukių $K_{i s}$ siekia 0,73. 2,5 \% LP kiekis keraminių šukių $K_{i s}$ padidina iki $0,82,2,5 \%$ VLP iki - 0,76, o 7,5 \% VLP iki - 0,81. Kaip matoma iš pateiktų duomenų, įdedant LP ar VLP, bandinių $K_{i s}$ didejja, todèl jau dabar pagal atliktus preliminarius skaičiavimus galima būtų prognozuoti, kad statybinès keramikos dirbinių gamyboje naudojant komunalinių deginimo atliekų LP ir VLP, jų atsparumas šalčiui mažès. Kuo $K_{i s}$ vertès didesnès, tuo turètų būti mažiau rezervinių porų, t. y. porų, neužpildytų vandeniu, kurios leidžia įvertinti išsiplètimo rezervą vandeniui virstant ledu.

Keraminè šukè su LP ir VLP yra sudètinga heterogeninè medžiaga, kurią sudaro kvarcas, hematitas, anortitas, kalcio sulfatas, $\mathrm{Ca}$ ir $\mathrm{Mg} / \mathrm{Fe} / \mathrm{Al}$ - silikatai, amorfinès/stiklinès fazès ir gana daug porų. Keraminių šukių mineraloginès sudèties ir mikrostruktūros pasikeitimai (3.12-3.15, 3.16, 3.31 ir 3.32 pav.) daro ịtaką keraminių šukių elgesiui šaldymo ir atšildymo sąlygomis.

Keraminių šukių ilgaamžiškumo bandymai, vertinant tūriniu ir vienpusiu šaldymo-atšildymo būdais, pateikti 3.6 ir 3.7 lentelèse. CS keraminè šukè tūrinio šaldymo-atšildymo būdu be pastebimų suirimo požymių atlaikẻ 350 ciklų, o vienpusiu šaldymo-atšildymo būdu - 550 ciklų, verta pabrěžti, kad toliau bandiniai bandomi nebuvo.

FA 2,5 ir FAW 5 keraminès šukès tūriniu šaldymo-atšildymo metodu atlaikè 75 ciklus, o FAW 2,5 - 100 ciklų (pažaidos tipas pagal standartą 0). Po 90 ciklo skilo (suirčių tipas pagal standartą 2, 3, 4, 7) FA 2,5 bandinys (3.33 pav., b), o FAW 2,5 bandinys skilo po 120 ciklų ( 3.33 pav., c).

Vienpusiu šaldymo-atšildymo būdu FA 2,5 ir FAW 5,0 bandiniai be pastebimų suirimo požymių atlaikẻ 100 ciklų, FAW 2,5 - 150 ciklų. Suirimo požymiai (suirčiu tipas pagal standartą 6,8 ) ant FA 2,5 bandinių pastebèti po 115 ciklų, o FAW 2,5 po 165 ciklų. FA 2,5 bandiniai skilo po 125 ciklų ( 3.34 pav., b), o FAW 2,5 po 190 ciklų (3.34 pav., c). 
3.6 lentelè. Keraminių šukių su lakiaisiais ir vandeniu apdorotais lakiaisiais pelenais atsparumo šalčiui (tūrinio) tyrimo rezultatai

Table 3.6. Clay bricks with fly ash and water-treated fly ash frost resistance (all-side) test results

\begin{tabular}{|c|c|c|c|c|c|c|c|c|c|c|c|}
\hline \multirow{2}{*}{$\begin{array}{l}\text { Keraminè } \\
\text { šukė }\end{array}$} & \multicolumn{11}{|c|}{ Ciklai } \\
\hline & 25 & 35 & 50 & 75 & 80 & 90 & 100 & 105 & 110 & 120 & 350 \\
\hline $\mathrm{CS}$ & $\mathrm{a}$ & $\mathrm{a}$ & $\mathrm{a}$ & $\mathrm{a}$ & $\mathrm{a}$ & $\mathrm{a}$ & $\mathrm{a}$ & $\mathrm{a}$ & $\mathrm{a}$ & $\mathrm{a}$ & $\mathrm{a}$ \\
\hline FA 2,5 & $\mathrm{a}$ & $\mathrm{a}$ & $\mathrm{a}$ & $\mathrm{a}$ & ap & $\mathrm{s}$ & & & & & \\
\hline FAW 2,5 & $\mathrm{a}$ & $\mathrm{a}$ & $\mathrm{a}$ & $\mathrm{a}$ & $\mathrm{a}$ & $\mathrm{a}$ & $\mathrm{a}$ & $\mathrm{a}$ & ap & $\mathrm{s}$ & \\
\hline FAW 5,0 & $\mathrm{a}$ & $\mathrm{a}$ & $\mathrm{a}$ & $\mathrm{a}$ & $\mathrm{a}$ & ap & ap & $\mathrm{s}$ & & & \\
\hline FAW 7,5 & $\mathrm{a}$ & $\mathrm{a}$ & $\mathrm{a}$ & $\mathrm{a}$ & $\mathrm{S}$ & & & & & & \\
\hline
\end{tabular}

Pastaba: a - atlaikè $n$ ciklų be pastebimų suirimo požymiu (suirčių tipas 0), ap - atsirado pažaidos (įtrūkis $\leq 0,2 \mathrm{~mm}$; ịtrūkis $>0,2 \mathrm{~mm}$; sluoksninis, žvyninis lupimasis; lūžis; duobutė) (suirčių tipas 1, 2, 3, 4, 5, 6); s- sluoksniavimasis, lūžis (suirčių tipas 7, 8).

3.7 lentelè. Keraminių šukių su lakiaisiais ir vandeniu apdorotais lakiaisiais pelenais atsparumo šalčiui (vienpusio) tyrimo rezultatai

Table 3.7. Clay bricks with fly ash and water-treated fly ash frost resistance (one-side) test results

\begin{tabular}{|l|l|l|l|l|l|l|l|l|}
\hline \multirow{2}{*}{$\begin{array}{l}\text { Keramine } \\
\text { ške }\end{array}$} & \multicolumn{9}{|c|}{ Ciklai } \\
\cline { 2 - 10 } & 50 & 100 & 115 & 125 & 150 & 165 & 190 & 550 \\
\hline CS & a & a & a & a & a & a & a & a \\
\hline FA 2,5 & a & a & ap & s & & & & \\
\hline FAW 2,5 & a & a & a & a & a & ap & s & \\
\hline FAW 5,0 & a & a & a & ap & s & & & \\
\hline FAW 7,5 & a & ap & s & & & & & \\
\hline
\end{tabular}

Pastaba: a - atlaikè $n$ ciklų be pastebimų suirimo požymiu (suirčių tipas 0), ap - atsirado pažaidos (įtrūkis $\leq 0,2 \mathrm{~mm}$; ịtrūkis $>0,2 \mathrm{~mm}$; sluoksninis, žvyninis lupimasis; lūžis; duobute) (suirčių tipas 1, 2, 3, 4, 5, 6); s - sluoksniavimasis, lūžis (suirčių tipas 7, 8)

Ivvertinus gautus tyrimų rezultatus nustatyta, kad įdejjus LP ar didejjant VLP kiekiui, keraminių šukių ilgaamžiškumas, vertinant pagal atsparumą šalčiui, mažeja. Didejjant LP ir VLP kiekiui, keraminèje šukèje didejja ir kalcio junginių kiekis joje. Tokių junginių atsiradimas, kaip minèta, padidina gaminių poringumą bei vandens ịmirkị $(3.26,3.28$ pav.). Didejantis poringumas ir vandens įmirkis daro 
neigiamą įtaką gaminių atsparumui šalčiui, nustatytam tiek vienpusio, tiek tūrinio šaldymo ir atšildymo būdais. Kalcio junginių neigiamą ịtaką šalčio atsparumui patvirtina ir kitų autorių atlikti moksliniai darbai (Sanchez de Rojasa et al., 2011).

Atlikus ilgaamžiškumo tyrimus galima konstatuoti, kad nagrinėjami keraminiai bandiniai CS, FA 2,5, FAW 2,5 ir FAW 5, kurių atsparumas šalčiui buvo nustatytas vienpusio šaldymo-atšildymo būdu, atliekant 100 ciklų bandymą, atsparumo šalčiui klase - F2 (vienpusis - 100 ciklų). Remiantis gautais rezultatais galima teigti, kad tokie bandiniai gali būti naudojami stipriai ardančioje aplinkoje. FAW 7,5 bandinių atsparumo šalčiui klasè - F1 (vienpusis - 75 ciklų). FAW 7,5 gali būti naudojami vidutiniškai ardančioje aplinkoje.

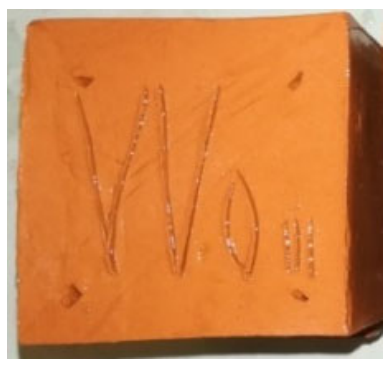

a)

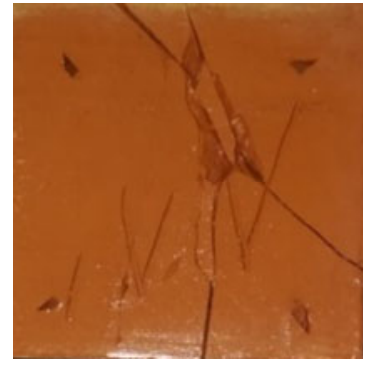

b)

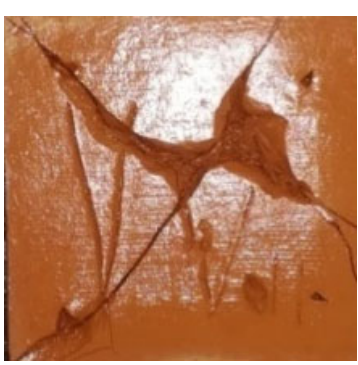

c)

3.33 pav. Keraminiai bandiniai po atsparumo šalčiui tūrinio šaldymo-atšildymo būdu:

a) CS bandinys po 350 ciklų; b) FA 2,5 bandinys po 90 ciklų;

c) FAW 2,5 bandinys po 120 ciklu

Fig. 3.33. Clay samples test subjects after frost resistance (all-side) test done by freezing and unfreezing: a) CS after 350 cycles; b) FA 2.5 after 90 cycles;

c) FAW 2.5 after 120 cycles

Apibendrinant galima teigti, kad keraminių bandinių CS, FA 2,5, FAW 2,5, FAW 5, ištirtų vienpusio šaldymo-atšildymo būdu, pagal gautus rezultatus ir dabar galiojančius normatyvinius dokumentus atsparumo šalčiui klasė yra F2 (100 ciklų) ir tokie gaminiai gali būti naudojami stipriai ardančioje aplinkoje. Tačiau, palyginus šių bandinių fizikinius ir mechaninius parametrus $(3.25,3.26,3.28$ ir 3.30 pav.) bei mikrostruktūrą (3.31 pav.), matoma, kad tarp parametrų bei mikrostruktūros yra gana didelių skirtumų. Todèl, atsižvelgiant ị ištirtą bandinių mikrostruktūrą ir gautas savybes (poringumą, tankį, gniuždymo stiprị ir pan.), labai abejotina, kad FA 2,5, FAW 2,5, FAW 5 gali būti naudojami stipriai ardančioje aplinkoje.

Taip pat verta paminèti, kad daugelio mokslininkų nuomone (de Almeida, 2014; Kizinievič, 2008; Smith et al., 2016), toks ciklų skaičius, atliekant vienpusio atsparumo šalčiui tyrimus, yra gerokai per mažas, kad gaminius galima būtu 
priskirti F2 klasei. Atlikti šių mokslininkų lyginamieji tyrimai parodè, kad vienpusio šaldymo-atšildymo metodu ištirti gaminiai turètų atlaikyti be pastebimų suirimo požymių daug didesnį ciklų skaičių (pvz., 300 ciklų), kad juos būtų galima naudoti stipriai ardančioje aplinkoje.

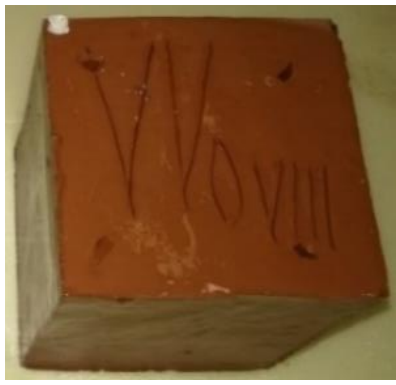

a)

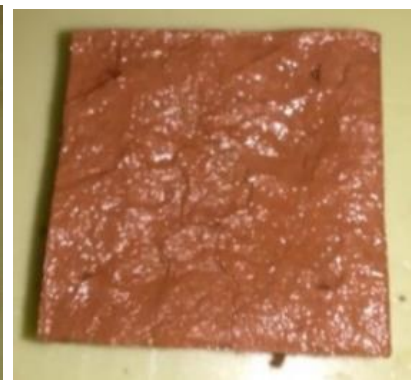

b)

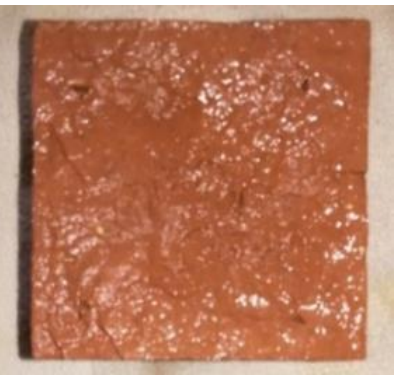

c)

3.34 pav. Keraminiai bandiniai po atsparumo šalčiui vienpusio šaldymo-atšildymo būdu:

a) CS bandinys po 550 ciklų; b) FA 2,5 bandinys po125 ciklų;

c) FAW 2,5 bandinys po 190 ciklų

Fig. 3.34. Clay samples test subjects after frost resistance (one-sided) test done by

freezing and unfreezing: a) CS after 550 cycles; b) FA 2.5 after 125 cycles;

c) FAW 2.5 after 190 cycles

\subsection{Keraminių šukių su dugno pelenais tyrimai}

\subsubsection{Keraminių šukių su dugno pelenais mineraloginès sudèties tyrimai}

Atlikti mineraloginès sudèties C, BA 5, BA 10, BA 15 keraminių šukių tyrimai parode, kad visuose bandiniuose identifikuoti anortito $\left(\mathrm{CaAl}_{2} \mathrm{Si}_{2} \mathrm{O}_{8}\right)$, kvarco $\left(\mathrm{SiO}_{2}\right)$, špinelio $\left(\mathrm{MgAl}_{2} \mathrm{O}_{4}\right)$, hematito $\left(\mathrm{Fe}_{2} \mathrm{O}_{3}\right)$, diopsido $\left(\mathrm{MgCaSi}_{2} \mathrm{O}_{6}\right)$ mineralai. Minèti mineralai, t. y standartiniai mineralai, susidarantys gamtinių aliumosilikatinių žaliavų degimo metu. C, BA 5 ir BA 15 keraminių šukių mineraloginès sudèties tyrimų rezultatai pateikti 3.35-3.37 pav.

Nustatytų mineralų intensyvumas skiriasi nedaug. Didesnis skirtumas pastebimas lyginant diopsido ir anortito (smailès persidengia) mineralų intensyvumą. Dugno pelenai, kaip ir lakieji pelenai, nors ir daug mažiau, bet vis dèlto užteršti sunkiujų metalų jonais, kaip ir buvo minèta, galimai sunkiųjų metalų jonai ịsiterpia ị diopsidų mineralų gardelę. 


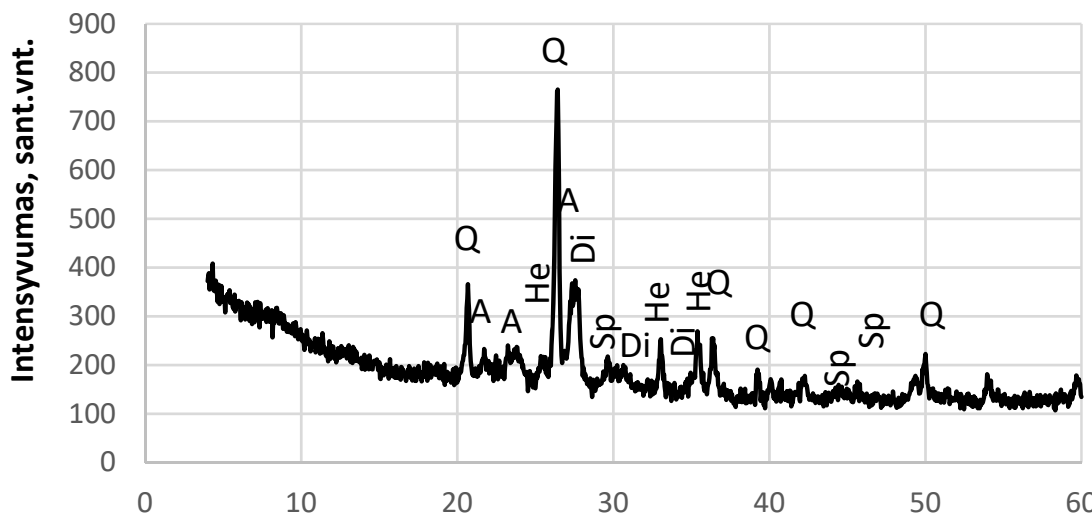

Difrakcijos kampas 2 $\theta$, laipsniais

3.35 pav. C keraminès šukès rentgenograma: $\mathrm{Q}$ - kvarcas; He - hematitas; $\mathrm{Sp}$ - špinelis; A - anortitas; $\mathrm{Di}$ - diopsidas)

Fig. 3.35. The X-ray diffraction pattern of C clay bricks: $\mathrm{Q}$ - quartz; He - hematite; $\mathrm{Sp}$ spinel; A - anortite; Di - diopside

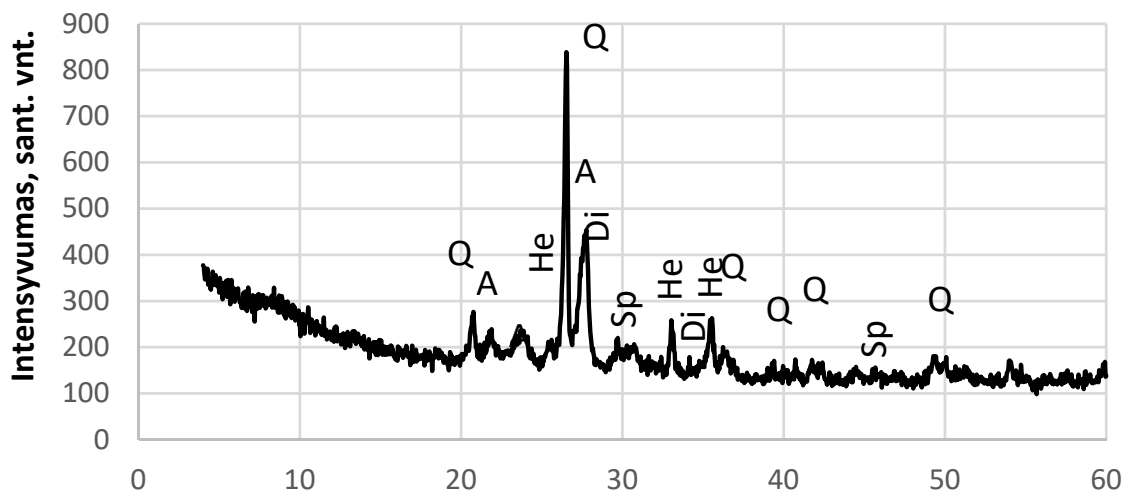

Difrakcijos kampas 2 $\theta$, laipsniais

3.36 pav. BA5 keraminės šukès rentgenograma: Q - kvarcas; He - hematitas; Sp - špinelis; A - anortitas; Di - diopsidas)

Fig. 3.36. The X-ray diffraction pattern of BA5 clay bricks: $\mathrm{Q}$ - quartz; He - hematite; $\mathrm{Sp}$ - spinel; A - anortite; Di - diopside 


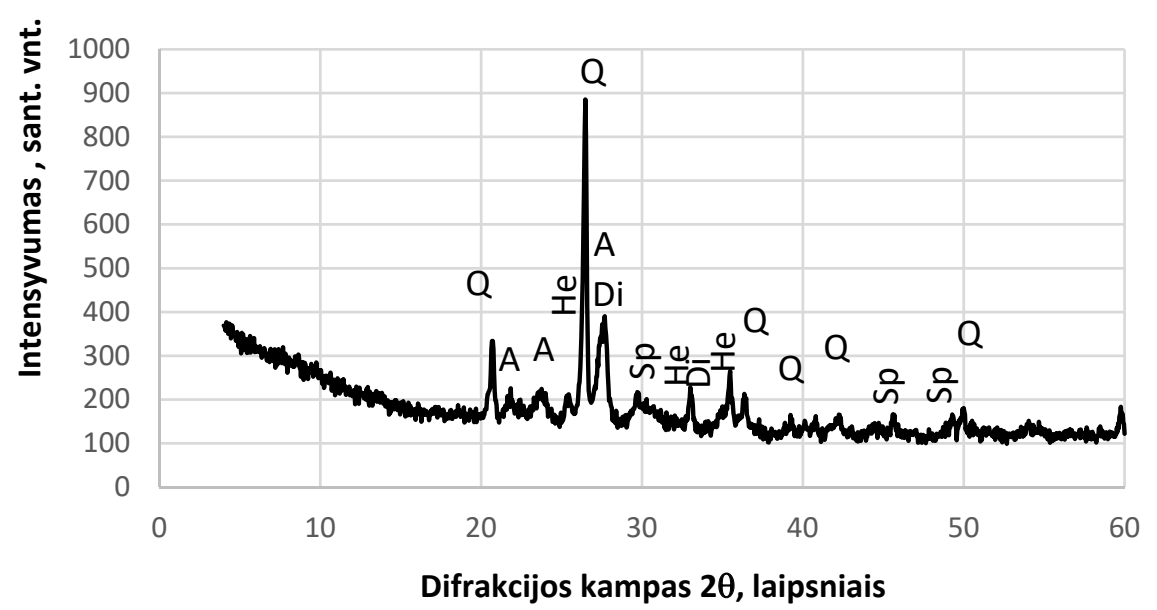

3.37 pav. BA15 keraminès šukès rentgenograma: Q - kvarcas; He - hematitas; $\mathrm{Sp}$ - špinelis; A - anortitas; Di - diopsidas)

Fig. 3.37. The X-ray diffraction pattern of BA15 clay bricks: Q - quartz; He - hematite; $\mathrm{Sp}$ - spinel; A - anortite; $\mathrm{Di}$ - diopside

\subsubsection{Keraminių šukių su dugno pelenais termografiniai tyrimai}

Molio diferencinès terminès analizès tyrimai pateikti 2.4 paveiksle (žr. 2.1 poskyrit).

Palyginus C keraminès šukès ir keraminių šukių su DP termografinius tyrimus, didelių skirtumų nepastebèta. Pirmas endoterminis efektas bandinių su DP vyksta $92-102{ }^{\circ} \mathrm{C}$ temperatūrose, masès nuostoliai siekia $1,7-1,8 \%$. Nagrinèjamos $\mathrm{C}$ keraminès šukès šio endoterminio efekto maksimumas pastebimas $94{ }^{\circ} \mathrm{C}$ temperatūroje, masès nuostoliai siekia 1,7 \% (2.4 pav.). Šio efekto metu tiriami bandiniai netenka drègmès, bandiniai susitraukia. Toliau stebimas BA 5, BA 10 ir BA 15 keraminių šukių egzoterminis efektas, kurio maksimumas pasiekiamas 328-331 ${ }^{\circ} \mathrm{C}$ temperatūroje, masès nuostoliai siekia 2,6-2,7 \%. C keraminès šukès šis efektas yra žemesneje $\sim 320^{\circ} \mathrm{C}$ temperatūroje, masès nuostoliai didesni ir siekia 3,2\%. Chemiškai sujungto vandens keraminių šukių su DP atskilimo maksimumas fiksuojamas $506-509{ }^{\circ} \mathrm{C}$ temperatūroje, masès nuostoliai sudaro $5,0 \%$. Kitas keraminių šukių su DP endoterminio efekto maksimumas fiksuojamas $744-764{ }^{\circ} \mathrm{C}$ temperatūroje, masès nuostoliai siekia 9,8-10,7\% (3.38-3.40 pav.). C bandinio endoterminis efektas ịvyksta $735^{\circ} \mathrm{C}$ temperatūroje, masès nuostoliai $-10 \%$ (2.4 pav.). 
İvertinus gautus rezultatus, manoma, kad DP daro įtaką molyje esantiems magnio ir kalcio karbonatų skilimams $\left(748-764{ }^{\circ} \mathrm{C}\right.$ temperatūra), jis vyksta aukštesnejje temperatūroje, taip pat sumažèja reakcijos po smailèmis plotas. Tai lemia keraminès šukès kristalinès gardelès aukštesnèje temperatūroje susidarymą bei neigiamai veikia naujų termodinamiškai stabilių fazių (pvz., anortito) formavimąsi.

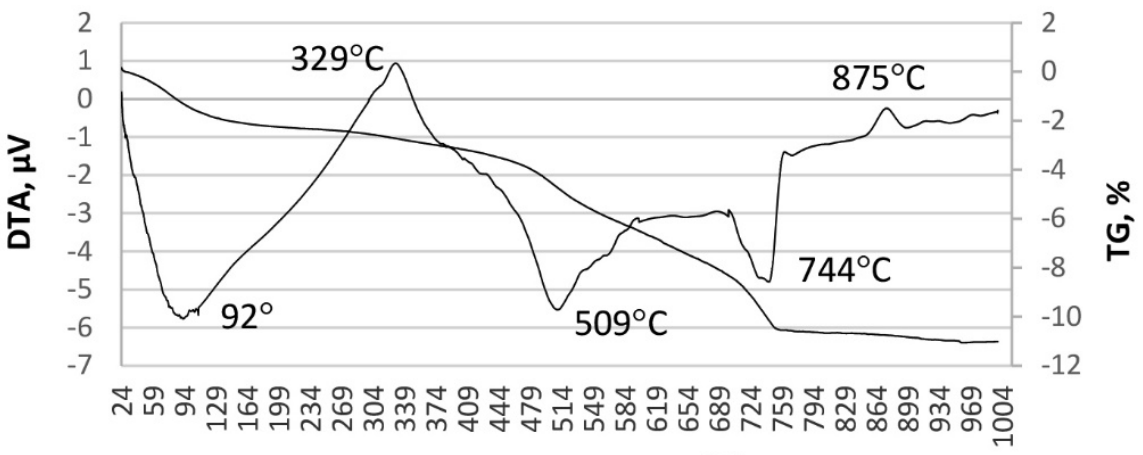

Temperatūra, ${ }^{\circ} \mathrm{C}$

3.38 pav. BA5 keraminès šukiès termograma

Fig. 3.38. Thermogram of BA5 clay bricks

Bandinių su DP egzoterminiai efektai, kai suyra hidrožèručio kristalo gardelè ir susidaro naujos išsikristalizavusios (špinelio, dioksido) fazès, vyksta 875$878{ }^{\circ} \mathrm{C}$ temperatūrose (3.38-3.40 pav.), panašiai kaip ir kontrolinès keraminès šukès (2.4 pav.).

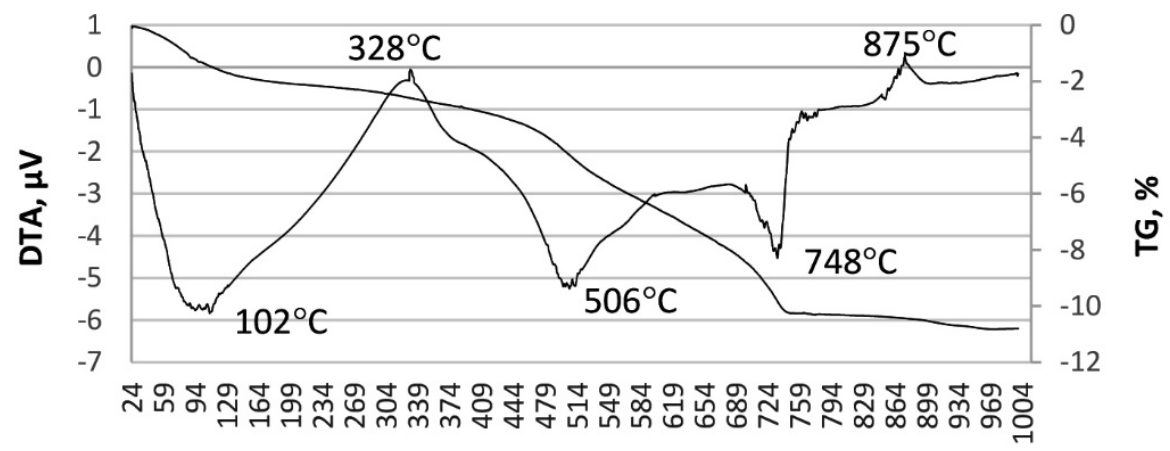

Temperatūra, ${ }^{\circ} \mathrm{C}$

3.39 pav. BA10 keraminès šukiès termograma

Fig. 3.39. Thermogram of BA10 clay bricks 


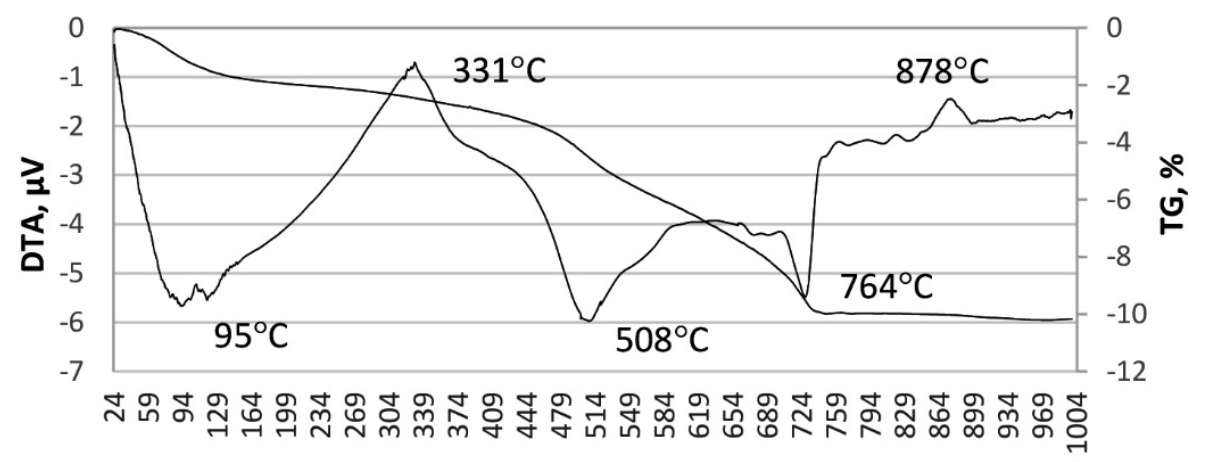

Temperatūra, ${ }^{\circ} \mathrm{C}$

3.40 pav. BA15 keraminès šukiès termograma

Fig. 3.40. Thermogram of BA15 clay bricks

\subsubsection{Sunkiụjụ metalų, chloridụ ir sulfatụ išsiplovimo iš keraminiu šukių su dugno pelenais ir radioaktyvumo tyrimai}

Atlikti tyrimai parode, kad DP randamų sunkiụjų metalų, chloridų ir sulfatų kiekiai nèra dideli ir neviršija LR AM įsakyme D1-805 pateiktu verčių, todèl pagal galiojantị normatyvinị dokumentą (LR AM ịsakymas D1-805) komunalinių deginimo atliekų šlakas ir pelenai gali būti naudojamas civilinèje ir statybos inžinerijoje (žr. 1.1 lentelę). Atkreiptinas dèmesys, nors ir nustatyta, kad DP gali būti naudojami ịvairių statybinių medžiagų gamyboje (LR AM ịsakymas D1-805, 1.2 lentelè), tačiau buvo atlikti ir nagrinejjamų keraminių šukių su DP sunkiųju metalų, sulfatų, chloridų išsiplovimo tyrimai.

Atlikti sunkiụjų metalų išsiplovimo iš keraminių šukių su DP tyrimai (3.413.42 pav.) parodè, kad didèjant keraminèje šukèje DP kiekiui, sunkiųjų metalų, chloridų bei sulfatų išsiplovimo iš nagrinejjamų keraminių šukių koncentracijos didèja. Pavyzdžiui, įdedant $15 \%$ DP ị keraminę šukę ir išdegant ją $1000{ }^{\circ} \mathrm{C}$ temperatūroje, $\mathrm{Zn}$ išsiplovimo iš keraminès šukès koncentracija padidejo 2,3 karto lyginant su kontroline keramine šuke, net 160 kartų padidejo $\mathrm{Cu}, 10$ kartų - $\mathrm{Pb}$ ir 2,6 karto - $\mathrm{Cr}$ išsiplovimo koncentracijos. Taip pat 2 kartus padidejo sulfatu ir 3,3 karto chloridų išsiplovimo koncentracijos. Tačiau verta pabrèžti, kad $\mathrm{Cu}, \mathrm{Cd}$, $\mathrm{Cr}, \mathrm{Pb}, \mathrm{Zn}, \mathrm{Ni}$, chloridų bei sulfatų išsiplovimo vertès neviršija galiojančių normatyvinių dokumentų inertinių atliekų išsiplovimo ribinių verčių pagal 2003/33/EC reikalavimą (3.41-3.42 pav.). İrodyta ir patvirtinta, kad komunalinių atliekų dugno pelenai gali būti saugiai naudojami keraminių dirbinių gamyboje nesukeliant pavojaus aplinkai ar žmogaus sveikatai. 


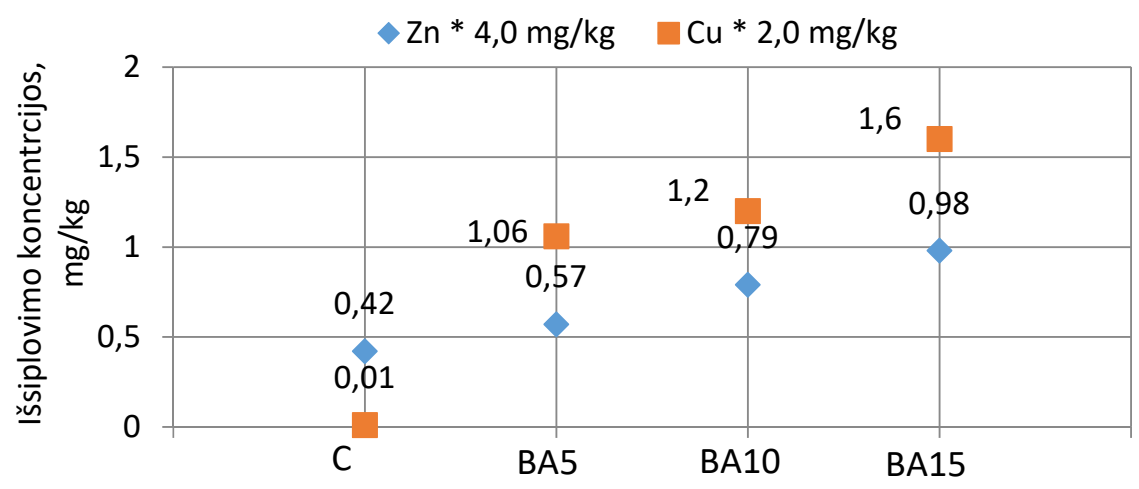

Keraminè šukè

a)

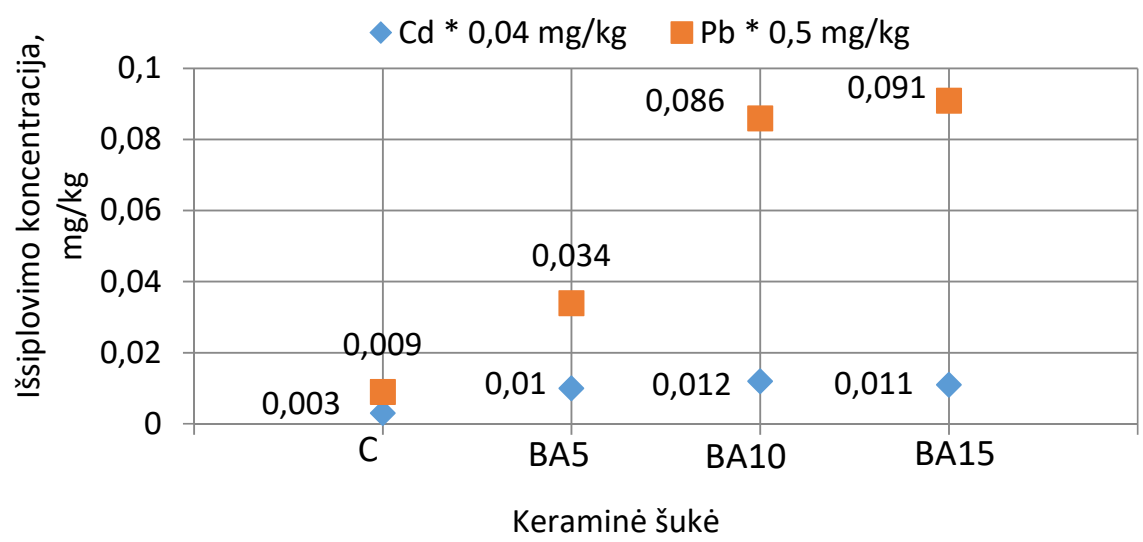

b)

3.41 pav. Keraminių šukių su dugno pelenais $\mathrm{Zn}, \mathrm{Cu}, \mathrm{Cd}$, Pb sunkiųjų metalų išsiplovimo rezultatai: a) $\mathrm{Zn}, \mathrm{Cu}$ išsiplovimo koncentracijos; b) $\mathrm{Cd}, \mathrm{Pb}$ išsiplovimo koncentracijos (*pažymètos ribinès koncentracijos pagal 2003/33/EC)

Fig. 3.41. Results leaching of $\mathrm{Zn}, \mathrm{Cu}, \mathrm{Cd}, \mathrm{Pb}$ heavy metals from clay bricks with bottom ash: a) $\mathrm{Zn}, \mathrm{Cu}$ leaching concentrations; b) $\mathrm{Cd}$, Pb leaching concentrations (*marked concentration limits according to 2003/33/EC)

Keraminių šukių su dugno pelenais $\mathrm{pH}$ ir savitasis elektrinis laidumas yra didesni nei keraminių šukių be dugno pelenų. Dugno pelenuose esantys chloridų ir sulfatų kiekiai daro įtaką nagrinèjamų parametrų padidèjimui (3.8 lentelè). Keraminių šukių pH ir Sel pokytị lemia dugno pelenų keraminèje šukèje kiekis. Kuo didesnè DP procentinè dalis yra keraminèje šukejje, tuo didesnis ịvairių sunkiuju 
metalų bei kalcio karbonatų kiekis patenka ị keraminę šukę, todèl pH ir Sel vertès didejja. Nogales et al. (2011) teigia, kad dugno pelenų šarmingumą daugiausia lemia jo karbonatų, bikarbonatų ir hidroksidų, taip pat sunkiųjų metalų kiekis.

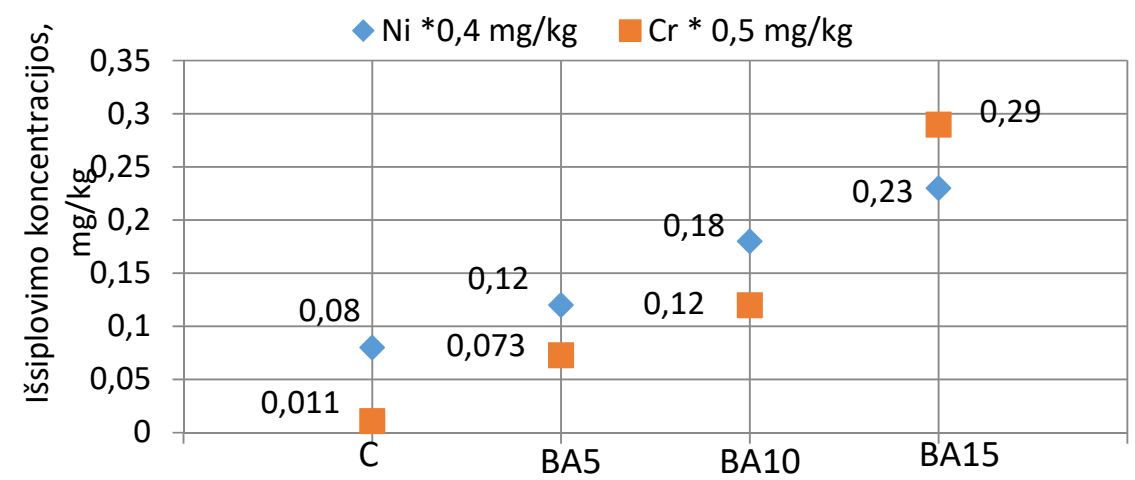

Keraminè šukè

a)

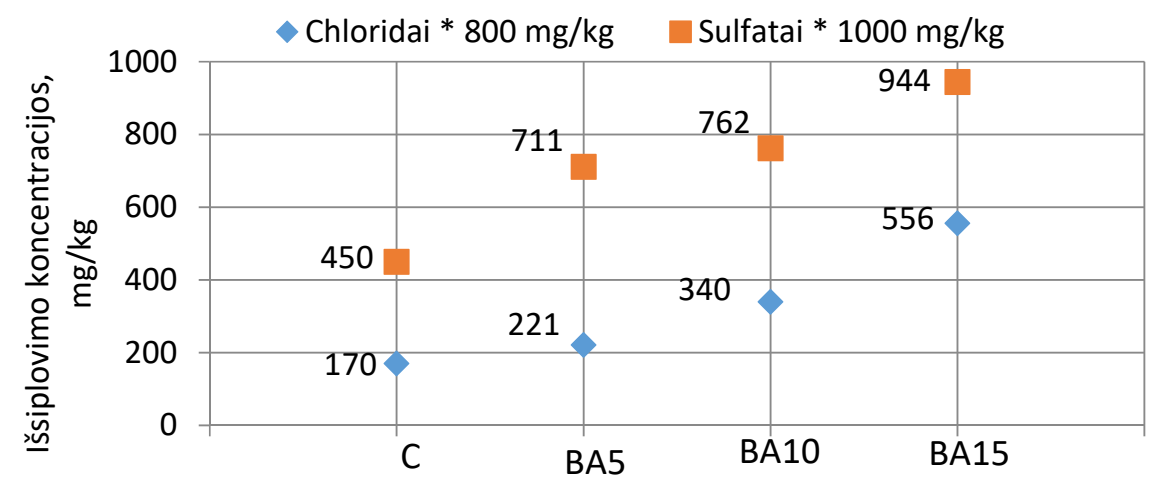

Keraminè šukè

b)

3.42 pav. Keraminių šukių su dugno pelenais $\mathrm{Ni}, \mathrm{Cr}$ sunkiujų metalų, chloridų bei sulfatų išsiplovimo rezultatai: a) $\mathrm{Ni}, \mathrm{Cr}$ išsiplovimo koncentracijos; b) chloridu ir sulfatu išsiplovimo koncentracijos (*pažymètos ribinès koncentracijos pagal 2003/33/EC)

Fig. 3.42. Results leaching of heavy metals, chlorides and sulphates from clay bricks with bottom ash: a) $\mathrm{Zn}, \mathrm{Cu}$ leaching concentrations; b) $\mathrm{Cd}, \mathrm{Pb}$ leaching concentrations;

c) $\mathrm{Ni}, \mathrm{Cr}$ leaching concentrations; d) chlorides and sulfates leaching concentrations (*marked concentration limits according to 2003/33/EC) 
Vertinant nagrinejjamų priedų tinkamumą naudoti keraminių dirbinių gamyboje, taip pat buvo atlikti tyrimai radioaktyviujų nuklidų keraminèse šukėse kiekiams nustatyti. Nustatyta, kad visuose bandiniuose randamų gamtinių radionuklidų K-40, Ra-226, Th-232 aktyvumas nekelia pavojaus žmonių sveikatai bei aplinkai (HN 85:2003, Nr.V-749), tai yra natūralus radiacinis fonas, kurị spinduliuoja radioaktyviosios uolienos.

3.8 lentelè. Keraminių šukių su dugno pelenais $\mathrm{pH}$ ir savitojo elektrinio laidumo parametrai

Table 3.8. $\mathrm{pH}$ and Sel parameters of clay bricks with bottom ash

\begin{tabular}{|l|l|l|l|l|}
\hline \multirow{2}{*}{$\mathrm{pH}$ ir Sel } & \multicolumn{4}{|l|}{ Keraminès šukès (pH ir Sel reikšmės) } \\
\cline { 2 - 5 } & $\mathrm{C}$ & BA 5 & BA 10 & BA 15 \\
\hline $\mathrm{pH}$ & 6,93 & 8,33 & 8,50 & 8,62 \\
\hline $\mathrm{Sel}, \mu \mathrm{S} / \mathrm{cm}$ & 120 & 150 & 233 & 288 \\
\hline
\end{tabular}

\subsubsection{Keraminių šukių su dugno pelenais mikrostruktūros tyrimai}

Išdegta $C$ keraminė šuke sudaryta iš tvirto fazių karkaso, kuriame tolygiai išsidèsčiusios įvairaus dydžio poros (3.43 pav., a). Porų struktūra susidaro technologinio proceso (formavimo, džiovinimo bei degimo) metu, o ypač svarbų vaidmeni atlieka galutinio technologinio proceso - degimo stadija. Keraminio gaminio $\mathrm{C}$ struktūra, eksploatacinès savybès priklauso nuo porų dydžio bei formos ir tarpusavio išsidèstymo.

Atlikti nagrinėjamų bandinių mikrostruktūros tyrimai parodè, kad įdedant ị formavimo masę $5 \% \mathrm{DP}$ ir išdegant ją, bandinių morfologija beveik nesikeičia lyginant su C bandiniais. Matoma tanki matrica, kurioje vyrauja nedidelis poru kiekis, skystosios fazès kiekis yra pakankamas bei tolygiai pasiskirsto po visą paviršių, defektinių vietų nepastebėta. Yra pailgų ir apvalių porų, kurių dydis svyruoja nuo $1 \mu \mathrm{m}$ iki $3 \mu \mathrm{m}$ (3.43 pav., a ir b). Nedidelis pasikeitimas struktūroje įvyksta įdedant $10 \%$ DP. Struktūroje vyrauja šiek tiek didesnis porų kiekis, atsiranda paviršiaus nelygumų, matomas mažesnis skystosios fazès kiekis (3.43 pav., c). Ryškesnis skirtumas pastebimas įdejjus 15 \% DP kiekį, atsiranda didelių, apvalių porų, skystosios fazès kiekio nepakanka, kad būtų užpildytos stambios 2$8 \mu \mathrm{m}$ apvalios poros (3.43 pav., d). Bandinių struktūroje (3.43 pav., d, e) susiformavusių stambesnių porų, atsitiktinių poringų ertmių atsiradimą lemia DP esantys organiniai likučiai $(3,2 \%)$ bei kalcio junginiai $(\mathrm{CaO}=20,8 \% ; 3.9$ ir 3.10 pav. $)$. 


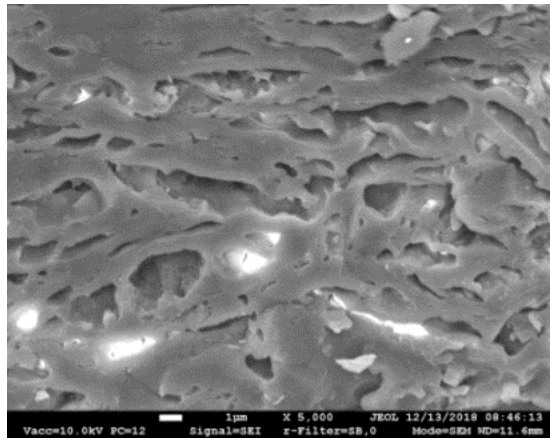

a)

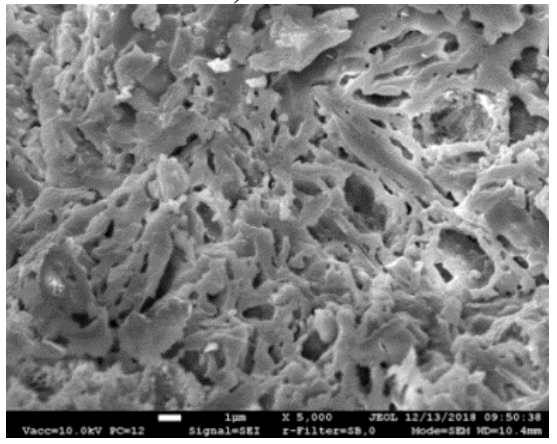

c)

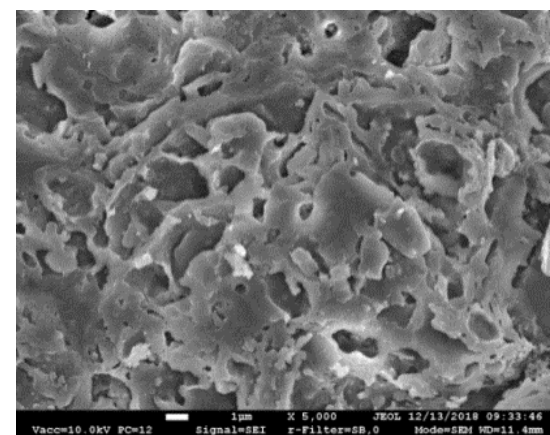

b)

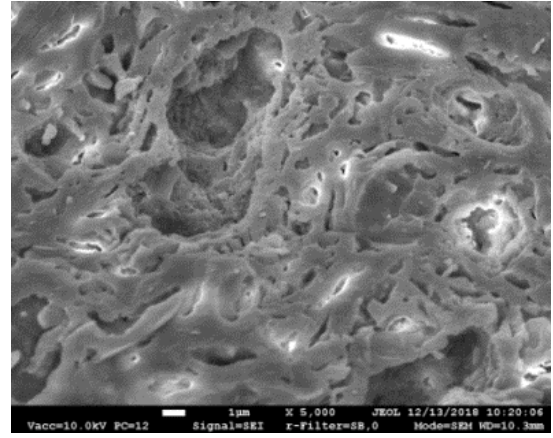

d)

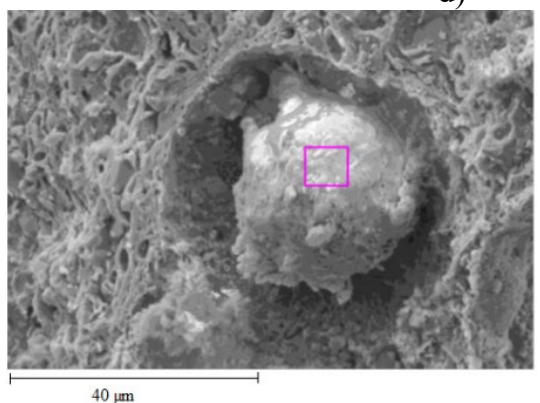

e)

3.43 pav. Keraminių šukių su dugno pelenais mikrostruktūra: a) C; b) BA 5; c) BA 10; d) BA 15 , e) BA 15 EDS tyrimo vieta

Fig. 3.43. Clay bricks with bottom ash microstructure: a) C; b) BA 5; c) BA 10; d) BA 15, e) BA 15 EDS place of research

Taip pat nustatyta, kad kai kuriose vietose tarp molio matricos ir DP dalelès sąlyčio zonoje gali būti silpnesnis ryšys (3.43 pav., e). Atlikti DP dalelès (3.43 pav., e) EDS tyrimai parodè, kad dalelę sudaro $\mathrm{O}-45,78 \%$, $\mathrm{Si}-21,45 \%$, $\mathrm{Ca}-15,35 \%, \mathrm{Al}-5,94 \%, \mathrm{Fe}-4,74 \%, \mathrm{Mg}-6,16 \%, \mathrm{Ti}-0,58 \%$. Didelis kalcio 
kiekis dalelèje leidžia daryti prielaidą, kad tai yra DP dalelè. Apibendrinant nagrinejjamų keraminių šukių mikrostruktūros tyrimų rezultatus galima teigti, kad mažiausias 5 \% DP kiekis neturi didelès įtakos keraminès šukès mikrostruktūrai, todèl galima prognozuoti, jog degtų C ir BA 5 bandinių savybès bus artimos. İdèjus ị formavimo masę $15 \%$ DP kiekị ir išdegant ją, savybės gali prastėti dẻl mažesnio amorfinès-stiklo fazès kiekio keraminiame kūne, atsiradusių didelių apvalių porų bei silpnesnio ryšio sąlyčio zonoje tarp molio matricos ir DP dalelių. Po komunalinių atliekų deginimo susidarę dugno pelenai dẻl turimų silicio junginių (47,6 \%), organinių junginių (3,2 \%) ir kalcio junginių (19,03 \%) veikia keraminę šukę kaip liesinantis priedas ir lemia didesnių, stambesnių porų keraminèje šukejje susiformavimą.

\subsubsection{Dugno pelenų ịtaka keraminių šukių fizikinėms ir mechaninèms savybèms}

Nustatyta, kad DP mažina keraminių šukių susitraukimą po džiovinimo ir degimo (3.44 pav.). C keraminès šukès susitraukimas po džiovinimo siekia $9,8 \%$, po degimo $1000{ }^{\circ} \mathrm{C}$ temperatūroje, išlaikant aukščiausioje degimo temperatūroje 1 val. $-12,7 \%$.

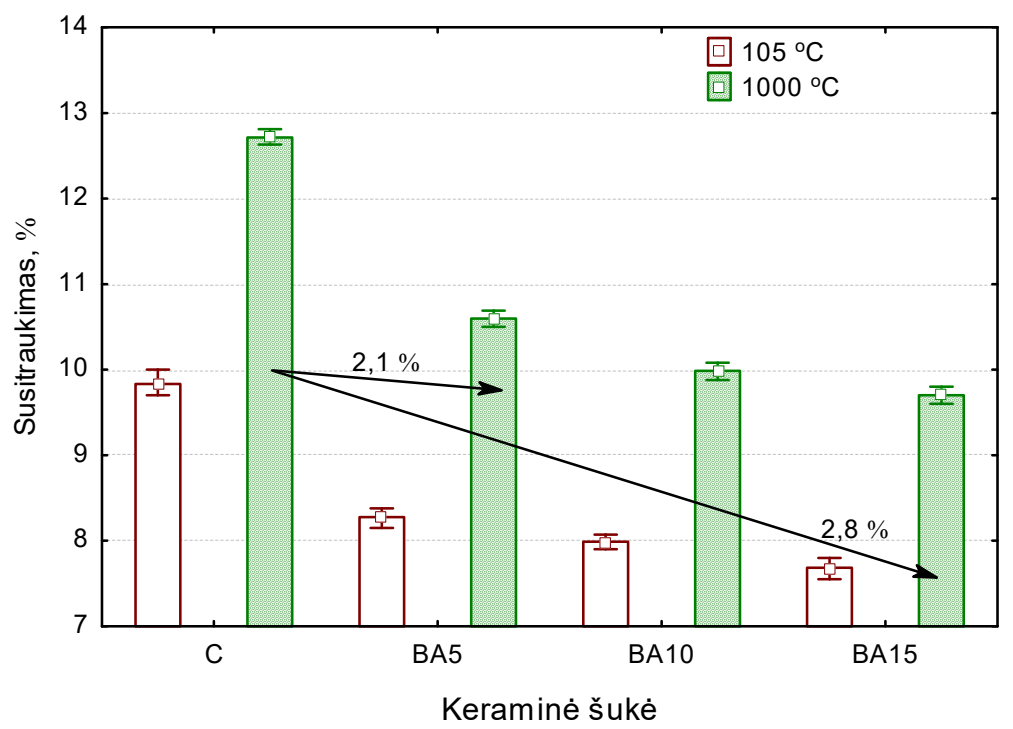

3.44 pav. Dugno pelenų įtaka keraminių šukių susitraukimams,

$(\rightarrow$ pokytis (\%) lyginant su C kontroline šuke)

Fig. 3.44. Bottom ash influence on clay bricks shrinkage, ( $\rightarrow$ change (\%) compared to C clay body) 
Idejjus ị formavimo mases 5,0 \% DP kiekį, susitraukimas po džiovinimo sumažèja iki 8,3 \%. Didinant DP formavimo masèse kieki nuo 5,0 \% iki $15 \%$, susitraukimas po džiovinimo sumažèja atitinkamai iki $8,0 \%$ ir 7,7\%. Mažiausias susitraukimas po degimo nustatytas įdejus i formavimo mases $10-15 \%$ DP kiekio, jis siekia apie $10 \%$. Susitraukimo mažejjimas po džiovinimo ir degimo įdejjus DP vyksta, nes dugno pelenai turi didelį $\mathrm{SiO}_{2}$ kiekị ir veikia keraminę šukę kaip liesinantis priedas.

Nustatyta, kad 5 \% DP nežymiai 8 \% mažina keraminių bandinių tankį, tačiau šios keraminès šukès gniuždymo stipris išlieka aukštas, labai artimas kontrolinès keraminès šukès (C keraminè šukè) gniuždymo stiprio nustatytam rezultatui ir siekia $44 \mathrm{MPa}$. İdèjus didesnị DP kiekị keraminių šukių tankis ir gniuždymo stipris mažèja. Keraminès šukès su 10 \% DP kiekiu tankis siekia $1,77 \mathrm{~g} / \mathrm{cm}^{3}$, o gniuždymo stipris - $35 \mathrm{MPa}$. Reikia pabrěžti, kad įdejjus ị formavimo masę $10 \%$ smèlio ir išdegus ją $1000{ }^{\circ} \mathrm{C}$ temperatūroje, gautos keraminès šukès tankis siekia $1,92 \mathrm{~g} / \mathrm{cm}^{3}$, o gniuždymo stipris - $35 \mathrm{MPa}$ (3.45 pav.).

Tyrimais įrodyta, kad DP, turintys didelį $\mathrm{SiO}_{2}$ kiekį, veikia keraminę šukę kaip liesinantis priedas, todèl gali būti naudojami vietoje smèlio keraminių dirbiniu gamyboje.

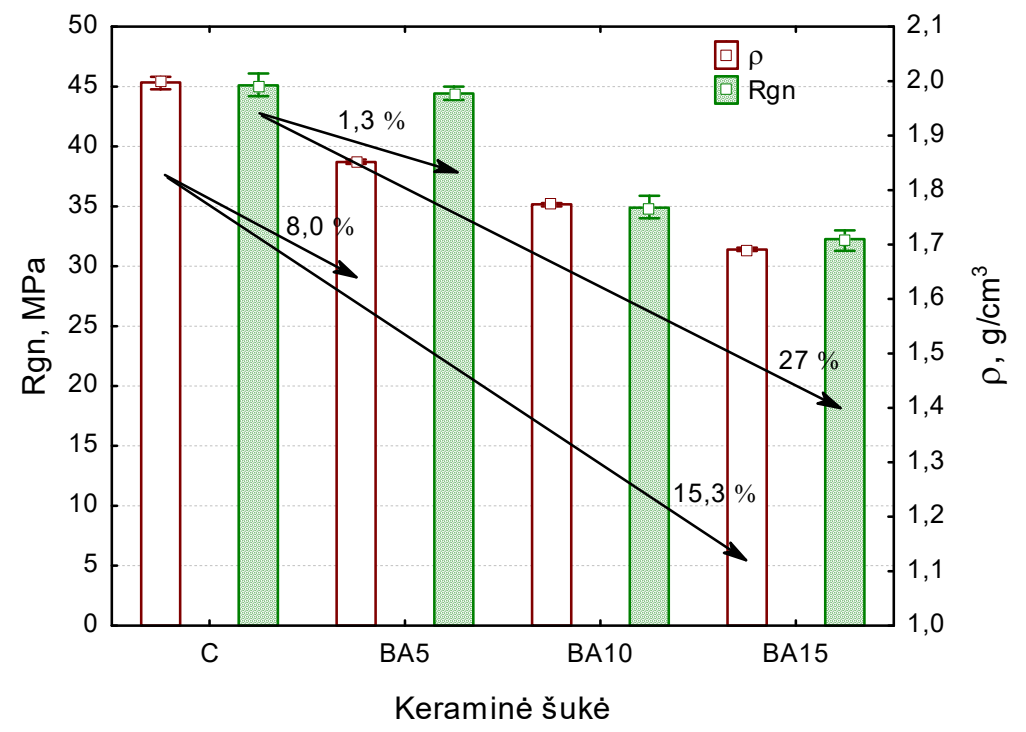

3.45 pav. Dugno pelenų ịtaka keraminių šukių tankiui $(\rho)$ ir gniuždymo stipriui $\left(R_{g n}\right)$, $(\rightarrow$ pokytis (\%) lyginant su $\mathrm{C}$ kontroline šuke)

Fig. 3.45. Effect of bottom ash on clay bricks density $(\rho)$ and compressive strength $\left(R_{g n}\right)$, $(\rightarrow$ change $(\%)$ compared to $\mathrm{C}$ clay body) 
Atlikti tyrimai parodè, kad DP didina keraminių šukių vandens įmirkị ir atviraji poringumą (3.46 pav.). Šios dvi savybès stipriai koreliuoja su keraminių dirbinių susiformavusios struktūros ypatumais (3.43 pav.). Mažiausias 5 \% DP kiekis keraminių šukių vandens įmirkị, palyginus su C keramine šuke, padidina $4 \%$, o atviraji poringumą $-7 \%$.

Nagrinejjamoms savybėms įtakos turi porų dydis, forma ir tarpusavio pasiskirstymas, taip pat skystosios fazès kiekis, susiformavęs degimo metu. Skystosios fazès kiekis, kaip minèta, nèra pakankamas, kad būtų užpildyta didesnè dalis keraminès šukès, nes neplastiškos DP dalelès molio dalelèms neleido maksimaliai priartèti vienai arčiau kitos, dèl to tarp molio matricos ir DP dalelių sąlyčio zonoje susiformavo papildomos poros (3.43 pav., e). Visi šie reiškiniai didina degtų bandinių vandens įmirkị ir atviraji poringumą, bendraji poringumą, taip pat mažina sąlyginių porų ir kapiliarų sienelių storị (3.47 pav.). Sąlyginis porų ir kapiliarų sienelių storis, įdejjus ị formavimo mases $5 \% \mathrm{DP}$ ir išdegant $1000{ }^{\circ} \mathrm{C}$ temperatūroje, sumažejo $23 \%$, lyginant su kontroline C keramine šuke. Didžiausias $15 \%$ DP kiekis keraminès šukès sąlyginį porų ir kapiliarų sienelių storį sumažina net $51 \%$, o bendraji poringumą padidina $15,4 \%$.

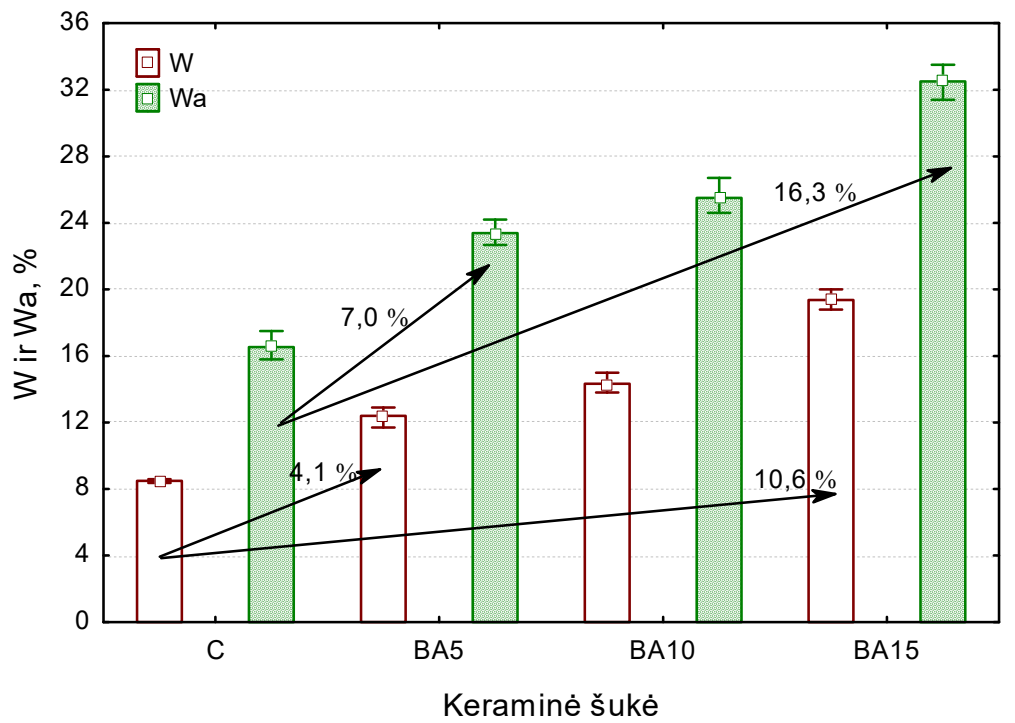

3.46 pav. Dugno pelenų įtaka keraminių šukių įmirkiui $(W)$ ir atvirajam poringumui $\left(W_{a}\right),(\rightarrow$ pokytis $(\%)$ lyginant su C kontroline šuke)

Fig. 3.46. Effect of bottom ash on open porosity $\left(W_{a}\right)$ and water absorption $(W)$, $(\rightarrow$ change $(\%)$ compared to C clay body) 


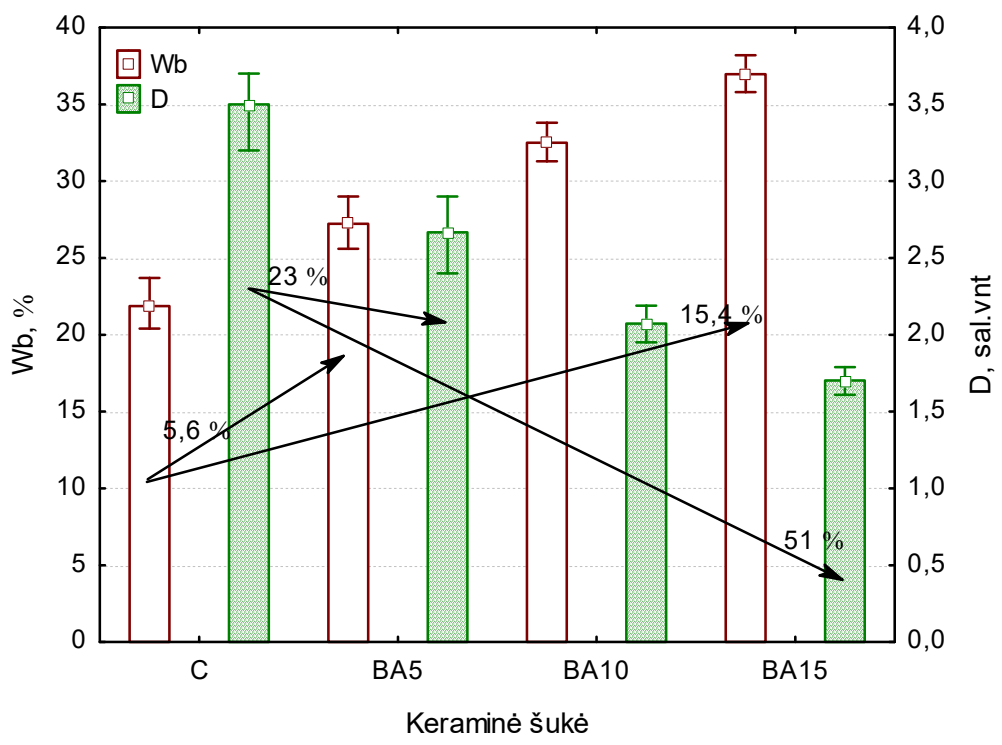

3.47 pav. Dugno pelenų įtaka keraminių šukių bendrajam poringumui $\left(W_{b}\right)$ bei sąlyginių porų ir kapiliarų sienelių storiui $(D),(\rightarrow$ pokytis $(\%)$ lyginant su C kontroline šuke) Fig. 3.47. Effect of bottom ash on total porosity $\left(W_{b}\right)$ and relative thickness of pore and capillary walls $(D),(\rightarrow$ change $(\%)$ compared to C clay body)

\subsubsection{Keraminių šukių su dugno pelenais ilgaamžiškumas}

Nagrinèjamų keraminių šukių su DP bendrasis poringumas siekia 27-35 \%. Bendrojo poringumo didejjimas, sąlyginis porų ir kapiliarų sienelių storio mažejjimas (3.47 pav.), įdejjus didesni DP kiekį, lemia didesnio kiekio stambesnių porų atsiradimą degtų bandinių struktūroje (3.43 pav.). Vanduo prisotinimo metu lengvai difunduoja i technologiniame procese bandiniuose susiformavusias poras ir kapiliarus. Užšaldant bandinį, vandens įsotintose porose dèl tūrio padidèjimo vandeniui virstant ledu, atsiranda slegis (apkrovos). Didelio skersmens porose vanduo lengviau užšąla nei mažo skersmens porose. Ilgalaikès kintamosios apkrovos nėra vienodos. Jų dydis priklauso nuo bandinių struktūros, porų dydžio ir išsidèstymo. Daugkartines apkrovas gali atlaikyti tankios struktūros bandiniai, neturintys defektinių vietų ir koncentruotų didelių atvirujų porų.

Keraminès šukès su 5-10 \% DP kiekiu išbandytos vienpusio šaldymo ir atšildymo metodu atlaikè 140 šaldymo ir atšildymo ciklų be pastebimų pažaidų (3.10 lentelè). Tęsiant bandymus nustatyta, kad charakteringos vienpusio šaldymo ir atšildymo metodo pažaidos BA 5 keraminèje šukejje atsirado po 200 šaldymo ir atšildymo ciklų, keraminèje šukèje BA 10 atsirado po 150 ciklų (3.48 pav., d). 
3.9 lentelè. Keraminių šukių su dugno pelenais atsparumo šalčiui (tūrinio) tyrimo rezultatai

Table 3.9. Clay bricks with bottom ash frost resistance (all-side) test results

\begin{tabular}{|l|l|l|l|l|l|l|l|l|l|l|l|l|}
\hline \multirow{2}{*}{$\begin{array}{l}\text { Keramine } \\
\text { suke }\end{array}$} & \multicolumn{10}{|c|}{ Ciklai } \\
\cline { 2 - 15 } & 25 & 35 & 50 & 75 & 90 & 100 & $\begin{array}{l}110- \\
125\end{array}$ & 150 & $\begin{array}{l}160- \\
170\end{array}$ & 180 & 200 & 350 \\
\hline C & a & a & a & a & a & a & a & a & a & a & a & a \\
\hline BA 5 & a & a & a & a & a & a & ap & ap & s & & & \\
\hline BA 10 & a & a & a & a & a & ap & ap & s & & & & \\
\hline BA 15 & a & a & a & ap & ap & s & & & & & & \\
\hline
\end{tabular}

Pastaba: a - atlaikè $n$ ciklų be pastebimų suirimo požymių (suirčių tipas 0), ap - atsirado pažaidos (ịtrūkis $\leq 0,2 \mathrm{~mm}$; ịtrūkis $>0,2 \mathrm{~mm}$; sluoksninis, žvyninis lupimasis; lūžis; duobutè) (suirčių tipas 1, 2, 3, 4, 5, 6); s-sluoksniavimasis, lūžis (suirčių tipas 7, 8).

3.10 lentelè. Keraminių šukių su dugno pelenais atsparumo šalčiui (vienpusio) tyrimo rezultatai

Table 3.10. Clay bricks with bottom ash frost resistance (one-sided) test results

\begin{tabular}{|l|l|l|l|l|l|l|l|l|}
\hline \multirow{2}{*}{$\begin{array}{l}\text { Keramine } \\
\text { šuke }\end{array}$} & \multicolumn{7}{|c|}{ Ciklai } \\
\cline { 2 - 10 } & 50 & 100 & 140 & $\begin{array}{l}150- \\
180\end{array}$ & 200 & $\begin{array}{l}210- \\
230\end{array}$ & $\begin{array}{l}230- \\
250\end{array}$ & 550 \\
\hline C & a & a & a & a & a & a & a & a \\
\hline BA 5 & a & a & a & a & ap & ap & s & \\
\hline BA 10 & a & a & a & ap & s & & & \\
\hline BA 15 & a & a & ap & s & s & & & \\
\hline
\end{tabular}

Pastaba: a - atlaikè $n$ ciklų be pastebimų suirimo požymių (suirčių tipas 0), ap - atsirado pažaidos (ịtrūkis $\leq 0,2 \mathrm{~mm}$; ịtrūkis $>0,2 \mathrm{~mm}$; sluoksninis, žvyninis lupimasis; lūžis; duobutè) (suirčių tipas 1, 2, 3, 4, 5, 6); s-sluoksniavimasis, lūžis (suirčių tipas 7, 8).

BA 5 ir BA 10 bandiniai, išbandyti tūrinio šaldymo ir atšildymo metodu, be pastebimų charakteringu pažaidu atlaike 100 ir atitinkamai 90 šaldymo ir atšildymo ciklų (3.9 lentelè). Po 125 šaldymo ir atšildymo ciklų BA 5 keraminëje šukejje prasideda bandinių destrukcijos procesai, bandiniuose atsirado vizualiai matomų ịtrūkių, po 160 ciklų bandinys suiro. BA 10 pirmi destrukcijos požymiai pastebimi jau po 100 ciklų, toliau bandinius šaldant-atšildant ịtrūkiai didèja, o po 150 ciklų bandinys skilo. BA 15 suskyla ị gabalus jau po 100 šaldymo ir atšildymo 
ciklų. Šaldant tūriniu būdu, vanduo migruoja ị mažiau įsotintus gilesnius bandinio sluoksnius, tačiau migruoja visomis bandinio šaldomomis plokštumomis, o paviršiniuose ploto sluoksniuose vanduo šąla daug greičiau nei vienpusio užšalimo atveju. Todèl porose judantis, užšąlantis ir atšildomas vanduo dèl susidariusių daugkartinių apkrovų i porų sieneles daug greičiau ardo bandinius.

Gauti keraminių šukių su DP ilgaamžiškumo (atsparumo šalčiui) tyrimo rezultatai rodo, kad 15 \% DP kiekis gerokai mažina bandinių atsparumą šalčiui, nustačius tiek tūriniu, tiek vienpusiu šaldymo-atšildymo metodais. BA 15 bandinių atsparumas šalčiui gerokai mažèja, nes struktūroje atsiranda didelių susisiekiančių porų, kurios lengvai užsipildo vandeniu (3.43 pav.). Didesnèse porose vanduo greičiau užšąla, o atitirpinant ledą dèl padidejjusio vandens kiekio lengvai ir greitai issotina kitas gilesniuose sluoksniuose esančias poras ir kapiliarus. Todèl bandinio vandens ịgertis po kiekvieno ciklo vis didejja. Mažẻjant bandinių sąlyginiam porų ir kapiliarų sienelių storiui užšaldymo-atšildymo proceso metu susidarantis viršslègis porose daug greičiau suardo porų sieneles, todèl keraminėje šukejje greičiau vyksta destrukcijos procesai.

Atlikus ilgaamžiškumo tyrimus nustatyta, kad visų bandinių, kurių atsparumas šalčiui buvo ịvertintas vienpusio šaldymo-atšildymo būdu, atliekant 100 ciklu bandymą, atsparumo šalčiui klasè yra F2 (vienpusis - 100 ciklų). Tokie bandiniai gali būti naudojami stipriai ardančioje aplinkoje.

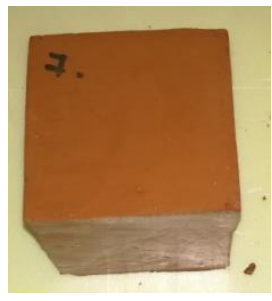

a)

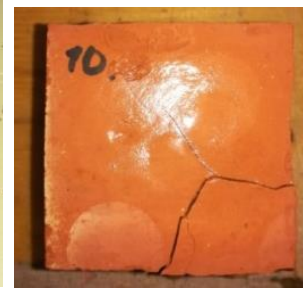

b)

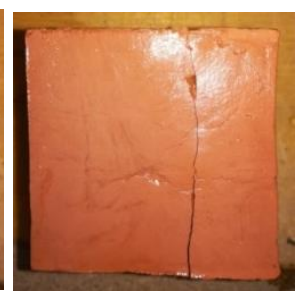

c)

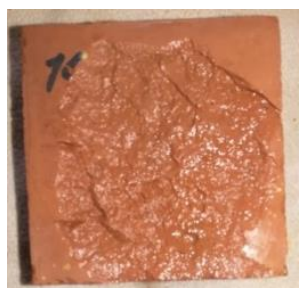

d)

3.48 pav. C, BA 5, BA 10 keraminiai bandiniai po atsparumo šalčiui tyrimo tūriniu ir vienpusiu šaldymo-atšildymo būdu: a) $C$ bandinys po 550 ciklų vienpusiu šaldymoatšildymo būdu; b) BA 10 bandinys po 150 ciklų tūriniu šaldymo-atšildymo būdu;

c) BA 5 bandinys po 170 ciklų tūriniu šaldymo-atšildymo būdu;

d) BA 10 bandinys po 200 ciklų vienpusiu šaldymo-atšildymo būdu

Fig. 3.48. C, BA 5, BA 10 clay samples after frost resistance all-side and one-side methods: a) C test subjects after the 550 cycles one-sided freeze-thaw method; b) BA 10 sample after 150 cycles of volume freeze-thaw; c) BA 5 sample after 170 cycles of volume freeze-thaw; d) BA 10 sample after 200 cycles of one-sided freeze-thaw 


\subsection{Trečiojo skyriaus išvados}

1. Atlikus eksperimentinius tyrimus nustatytas komunalinių deginimo atlieku lakiųjų ir vandeniu apdorotų lakiujų pelenų poveikis keraminių šukių mineraloginei sudecčiai. İdedant ị formavimo mases 2,5-7,5\% lakiųjų ir vandeniu apdorotų lakiujų pelenų kiekị ir išdegant jas $1000{ }^{\circ} \mathrm{C}$ temperatūroje, keraminèse šukèse, be standartinių mineralų (anortito, kvarco, hematito, diopsido, špinelio), papildomai susidaro kalcio sulfato mineralas; $\mathrm{CaSO}_{4}$ mineralas, $\mathfrak{i}-$ dẻjus didesnị nei 2,5\% lakiujų pelenų kiekị, difunduoja ị paviršių, sudarydami degtų bandinių paviršiuje purvinos geltonai baltos spalvos apnašas bei išsūdas, kurioms geltoną atspalvị suteikia lakiuosiuose pelenuose esančios vanadžio ir chromo druskos.

2. Lakieji ir vandeniu apdoroti lakieji pelenai neigiamai veikia molyje esančių mineralų amorfizacijos ir karbonatų skilimo procesus, mažindami termodinamiškai stabilios anortito fazès susidarymą, o tai daro neigiamą įtaką keraminių šukių stipruminėms savybėms. Lakiuosiuose ir vandeniu apdorotuose lakiuosiuose pelenuose esantys sunkieji metalai ịsiterpia ị špinelio ir diopsido mineralų struktūrą, taip sunkieji metalai imobilizuojami termodinamiškai stabiliose fazèse.

3. İdedant ị formavimo mases lakiuosius ir vandeniu apdorotus lakiuosius pelenus ir išdegant jas $1000^{\circ} \mathrm{C}$ temperatūroje, nustatyta, kad nagrinèjamų lakiųjų ir vandeniu apdorotų lakiujų pelenų cheminè sudetis (chloridai, sulfatai, $\mathrm{CaO}$ ) lemia kitokios keraminių šukių struktūros formavimąsi; susiformuojant kalcio sulfatui, garuojant chloridams, skylant $\mathrm{CaCO}_{3}$, struktūroje susiformuoja daugiau atviru porų, taip pat tarp identifikuoto $\mathrm{CaSO}_{4}$ mineralo ir molio matricos susiformuoja papildomų porų, o tai mažina keraminių šukių susitraukimą, tankį, gniuždymo stiprị, didina vandens įmirkị, poringumą, neigiamai veikia bandinių atsparumą šalčiui.

4. Nustatyta, kad 2,5\% lakiujų pelenų ir 2,5-7,5\% vandeniu apdorotų lakiuju pelenų kiekis daro įtaką degtų $1000{ }^{\circ} \mathrm{C}$ temperatūroje, išlaikant aukščiausioje degimo temperatūroje 1 val., keraminių šukių fizikinėms ir mechaninėms savybèms bei ilgaamžiškumui:

- 2,5\% lakiujų pelenų kiekis 1,8\% sumažina keraminių šukių susitraukimą po degimo, 6,3 \% sumažina tankị bei $22 \%$ - gniuždymo stiprị, 5,9\% padidina vandens ịmirkị ir 7,9\% - bendrajị poringumą; bandiniai tūrinio šaldymo-atšildymo metodu atlaiko 75 ciklus, vienpusiu šaldymo-atšildymo metodu atlaiko 100 ciklų;

- 2,5-7,5\% vandeniu apdorotų lakiųų pelenų kiekiai 1,8-3,2 \% sumažina keraminių gaminių susitraukimą po degimo, 4,1-7,8 \%- 
tankị, $14-31 \%$ - gniuždymo stiprị, 2,3-5,1\% padidina vandens įmirkị ir 3,7-8,0 \% - bendraji poringumą; bandiniai tūrinio šaldymoatšildymo metodu atlaiko 75-100 ciklų, vienpusiu šaldymo-atšildymo metodu atlaiko 50-150 ciklų;

5. Atlikus sunkiujų metalų, chloridų bei sulfatų iš keraminių šukių išsiplovimo tyrimus nustatyta, kad 2,5 \% lakiųjų pelenų arba 2,5-7,5 \% vandeniu apdorotų lakiujų pelenų priedai gali būti saugiai naudojami keraminių dirbinių gamyboje, kadangi išsiplovimo vertès pagal 2003/33/EC, neviršija inertiniu atliekų išsiplovimo ribinių verčių.

6. Remiantis atliktais keraminių šukių su 5,0-15\% komunalinių deginimo atliekų dugno pelenų kiekiais tyrimų rezultatais nustatyta, kad įdedant dugno pelenus keraminejje šukejje susidariusių anortito, kvarco, špinelio, hematito, diopsido mineralu intensyvumai skiriasi nedaug. Didinat $>10 \%$ dugno pelenų keraminejje šukejje kiekį, degtų bandinių mikrostruktūroje atsiranda stambesnių 2-8 $\mu \mathrm{m}$ porų, tarp keraminès šukès ir dugno pelenų dalelių sąlyčio zonoje pastebimas silpnesnis ryšys.

7. Eksperimentiniais tyrimais įrodyta, kad 5,0-15\% dugno pelenų kiekis daro įtaką keraminių šukių fizikinėms ir mechaninėms savybėms: 2,2-3,0 \% sumažina susitraukimą po degimo, 7,5-15\% - tankį, 1,0-27\% - gniuždymo stiprị, 4,4-10,8 \% padidina vandens ịmirkị, 7-16\% - atviraji poringumą; bandiniai su 5-10 \% dugno pelenų kiekiu tūrinio šaldymo-atšildymo metodu atlaiko 50-100 ciklų, vienpusiu šaldymo-atšildymo metodu atlaiko 100150 ciklų. 


\section{Bendrosios išvados}

1. Atlikti tyrimai parodè, kad po komunalinių atliekų deginimo susidarę lakieji pelenai ar vandeniu apdoroti lakieji pelenai daro ịtaką keraminès šukès, pagamintos naudojant lengvai lydų molị, mineraloginei sudèčiai, struktūrai ir savybèms:

1.1. İdèjus i formavimo mases $2,5-7,5 \%$ lakiujų ar vandeniu apdorotų lakiųjų pelenų keraminèse šukèse susidaro kalcio sulfato mineralas. 5,0 7,5\% ịdètas ị keraminę šukę lakiujų pelenų kiekis lemia tai, kad minètas mineralas difunduoja ị bandinio paviršių, sudarydamas apnašas bei išsūdas, o tai blogina estetinę keraminių šukių kokybę.

1.2. Lakiujų ir vandeniu apdorotų lakiujų pelenų cheminė sudètis daro ịtaką kitokios struktūros formavimuisi keraminèje šukejje. Susidarant kalcio sulfato mineralui, garuojant chloridams, skylant $\mathrm{CaCO}_{3}$, struktūroje susiformuoja daugiau pailgų, stambesnių, atvirų porų, o tai 3,7-8,0\% padidina keraminių šukių bendraji poringumą, 14-31 \% mažina stiprumines savybes, kas neigiamai veikia keraminių šukių ilgaamžiškumą.

1.3. Nustatyta, kad 2,5\% lakiųjų pelenų 1,8 \% sumažina keraminių šukių susitraukimą po degimo, $6,3 \%$ sumažina tanki bei $22 \%$ - gniuždymo stiprį, 5,9\% padidina vandens įmirkị ir 7,9\% - bendrajị poringumą, lyginant su keramine šuke be lakiųų pelenų. Bandiniai tūrinio šaldymo- 
atšildymo metodu atlaiko 75 ciklus, vienpusiu šaldymo-atšildymo metodu -100 ciklų.

1.4. Nustatyta, kad $2,5-7,5 \%$ vandeniu apdorotų lakiųų pelenų $1,8-3,2 \%$ sumažina degtų keraminių gaminių susitraukimą po degimo, 4,1-7,8 \% tankị, 14-31\% - gniuždymo stiprį, 2,3-5,1\% padidina vandens įmirki ir 3,7-8,0 \% - bendraji poringumą, lyginant su keramine šuke be vandeniu apdorotų lakiųjų pelenų. Bandiniai tūrinio šaldymo-atšildymo metodu atlaiko 75-80 ciklų, vienpusiu šaldymo-atšildymo metodu - 50150 ciklų.

2. Remiantis atliktais keraminių šukių su 5,0-15\% po komunalinių atliekų deginimo susidarančių dugno pelenų kiekiais tyrimų rezultatais nustatyta:

2.1. Didinant dugno pelenų kiekị vyksta keraminių šukių struktūros pasikeitimai - didèja porų tūris, tarp keraminès matricos ir dugno pelenų dalelès sąlyčio zonoje nustatytas silpnesnis ryšys, skystosios fazès kiekis tampa nepakankamas poroms užpildyti, o tai lemia stambesnių porų atsiradimą bei 5,6-15,4\% bendrojo poringumo padidejimą.

2.2. Nustatyta, kad 5,0-15\% dugno pelenų priedas daro įtaką keraminių šukių fizikinèms ir mechaninèms savybėms: 2,2-3,0 \% sumažina susitraukimą po degimo, 7,5-15\% - tankị, 1,0-27\% - gniuždymo stiprį, 4,4$10,8 \%$ padidina vandens įmirkị, $7-16 \%$ - atvirajị poringumą, lyginant su keramine šuke be dugno pelenų priedo. Bandiniai tūrinio šaldymoatšildymo metodu atlaiko 50-100 ciklų, vienpusiu šaldymo-atšildymo metodu - 100-150 ciklų.

3. Tyrimais ịrodytas, ekologiniu požiūriu veiksmingas, pavojingujų komunalinių deginimo atliekų lakiuosiuose ar vandeniu apdorotuose lakiuosiuose pelenuose bei dugno pelenuose esančių sunkiujų metalų, chloridų ir sulfatų keraminèse šukèse imobilizavimas. İdèjus ị keramines šukes $2,5 \%$ lakiujų pelenų, 2,5-7,5 \% vandeniu apdorotų lakiujų pelenų ar 5-15\% dugno pelenų, $\mathrm{Cu}, \mathrm{Cd}, \mathrm{Cr}, \mathrm{Pb}, \mathrm{Zn}, \mathrm{Ni}$, sulfatų ir chloridų ribinès išsiplovimo vertès, pagal 2003/33/EC normatyvinị dokumentą, neviršija inertinių atliekų išsiplovimo ribinių verčių. 


\section{Rekomendacijos}

1. Apibendrinant gautus tyrimo rezultatus, atsižvelgiant ị galimai nepastovią lakiujų pelenų cheminę sudètį, siekiant visiškai minimizuoti pavojingujų medžiagų (sunkiųjų metalų, chloridų bei sulfatų) išsiplovimo galimybes iš degtu gaminių, užtikrinant gaminių estetinę kokybę bei siekiant, kad keraminių šukių eksploatacinès savybès būtų artimos keraminèms šukėms, kuriose nebuvo naudojami lakieji pelenai, keraminių dirbinių gamyboje rekomenduojama utilizuoti iki 2,5\% lakiųjų pelenų arba iki 5,0 \% vandeniu apdorotų lakiųjų pelenų. Gautos keraminès šukès pasižymètų tokiomis eksploatacinėmis savybèmis: susitraukimas po degimo iki $9,5 \%$, tankis ne mažesnis kaip $1,7 \mathrm{~g} / \mathrm{cm}^{3}$, gniuždymo stipris ne mažesnis kaip $25 \mathrm{MPa}$, vandens įmirkis ne didesnis kaip $15 \%$, bendrasis poringumas ne didesnis kaip $31 \%$, atsparumas šalčiui tūrinio šaldymo-atšildymo metodu - 75-80 ciklų, vienpusiu šaldymo-atšildymo metodu 100-115 ciklų; verta pabrèžti, kad toks pavojingų lakiujų pelenų arba vandeniu apdorotų lakiųjų pelenų kiekis gali būti saugiai utilizuojamas statybinejje keramikoje nekeliant pavojaus gamtai bei žmonių sveikatai net gaminio gyvavimo ciklo pabaigoje.

2. Remiantis tyrimo rezultatais nustatyta, kad dugno pelenai keraminių dirbinių pramonèje gali pakeisti natūralų liesinantị priedą (smèlį), todẻl ke- 
raminių dirbinių gamyboje rekomenduojama naudoti iki $10 \%$ dugno pelenų. Gautos keraminès šukès pasižymètų tokiomis eksploatacinèmis savybėmis: susitraukimas po degimo - iki 10,5 \%, tankis ne mažesnis kaip $1,7 \mathrm{~g} / \mathrm{cm}^{3}$, gniuždymo stipris ne mažesnis kaip $35 \mathrm{MPa}$, vandens įmirkis ne didesnis kaip $14,5 \%$, bendrasis poringumas ne didesnis kaip $35 \%$, atsparumas šalčiui tūrinio šaldymo-atšildymo metodu - 90 ciklų, vienpusiu šaldymo-atšildymo metodu - 140 ciklų. 


\section{Literatūra ir šaltiniai}

An, J., Kim, J., Golestani, B., Tasneem, K. M., Muhit, B. A., \& Nam, B. H. (2014). Evaluating the Use of Waste-to-Energy Bottom Ash as Road Construction Materials, Final Report, Contract No.: BDK78-977-20, 97 p. https://rosap.ntl.bts.gov/view/dot/27252

Andrade, F. A., Al-Qurechi, H. A., \& Hotza, D. (2011). Measuring the plasticity of clays: A review, Applied Clay Science 51(1-2): 1-7. https://doi.org/10.1016/j.clay.2010.10.028

Andreola, F., Barbieri, L., Hreglich, S., Lancellotti, I., Morselli, L., Passarini, F., \& Vassura, I. (2008). Reuse of incinerator bottom and fly ashes to obtain glassy materials, Journal of Hazardous Materials 153: 1270-1274. https://doi.org/10.1016/j.jhazmat.2007.09.103

Andreola, F., Barbieri, L., Lancelloti, I., \& Pozzi, P. (2005). Recycling industrial waste in brick manufacture. Part 1, Materiales de Construcción 55: 5-16. https://iris.unimore.it/handle/11380/310614\#.XkaRIIhS-Ul

Arickx, S., Van Gerven, T., \& Vandecasteele, C. (2006). Accelerated carbonation for treatment of MSWI bottom ash, Journal of Hazardous Materials 137(1): 235-243. https://doi.org/10.1016/j.jhazmat.2006.01.059

Arsenovic, M., Radojevic, Z., \& Stankovic, S. (2012). Removal of toxic metals from industrial sludge by fixing in brick structure, Construction and Building Materials 37: 7-14. https://doi.org/10.1016/j.conbuildmat.2012.07.002 
Arsenovic, M., Radojevic, Z., Jakšic, Ž., \& Pezo, L. (2015). Mathematical approach to application of industrial wastes in clay brick production. Part 1: Testing and analysis, Ceramic International 41(3): 4890-4898. https://doi.org/10.1016/j.ceramint.2014.12.051

ASTM C326 - 09(2014). Standard Test Method for Drying and Firing Shrinkages of Ceramic Whiteware Clays, ASTM International

ASTM Standard D 4318:2005 Standard Test Methods for Liquid Limit Plastic Limit, and Plasticity Index of Soils, ASTM International.

Atterberg, A. (1911). Die Plastizität der Böden, Internationale Mitteilungen der Bodenkunde 1: 4-37.

Aubert, J. E., Husson, B., \& Sarramone, A. (2007). Utilization of municipal solid waste incineration (MSWI) fly ash in blended cement: Part 2. Mechanical strength of mortars and environmental impact, Journal of Hazardous Materials 146(1-2): 12-19. https://doi.org/10.1016/j.jhazmat.2006.11.044

Aubert, J. E., Husson, B., \& Sarramone, N. (2006). Utilization of municipal solid waste incineration (MSWI) fly ash in blended cement: Part 1: Processing and characterization of MSWI fly ash, Journal of Hazardous Materials 136(3): 624-631. https://doi.org/10.1016/j.jhazmat.2005.12.041

Baccoura, H., Medhioub, M., Jamoussi, F., Mhiri, T., \& Daoud, A. (2008). Mineralogical evaluation and industrial applications of the Triassic clay deposits, Southern Tunisia. Materials Characterization 59(11): 1613-1622. https://doi.org/10.1016/j.matchar.2008.02.008

Baciocchi, R., Costa, G., Lategano, E., Marini, C., Polettini, A., Pomi, R., Postorino, P., \& Rocca, S. (2010). Accelerated carbonation of different size fractions of bottom ash from RDF incineration, Waste Management 30(7): 1310-1317. https://doi.org/10.1016/j.wasman.2009.11.027

Bakker, E. J., Muchova, L., \& Rem, P. C. (2007). Economic recovery of precious metals from MSWI bottom ash, in 1st International Conference on Environmental Management, Engineering, Planning and Economics (CEMEPE 2007): 1-5.

Belevi, H., \& Moench, H. (2000). Factors determining the element behavior in municipal solid waste incinerators. 1. Field studies, Environmental Science and Technology 34(12): 2501-2506. https://doi.org/10.1021/es991078m

Belmonte, L. J., Ottosen, L. M., Kirkelund, G. M., Jensen, P. E., \& Vestbo, A. P. (2018). Screening of heavy metal containing waste types for use as raw material in Arctic clay-based bricks, Environmental Science and Pollution Research 25(33): 32831-32843. https://doi.org/10.1007/s11356-016-8040-z

Benson, C. H. \& Trast, J. M. (1995). Hydraulic conductivity of thirteen compacted clays, Clays Clay Minerals, 43(6):669-681. https://link.springer.com/article/10.1346/CCMN.1995.0430603 
Bertolini, L., Carsana, M., Cassago, D., Quadrio Curzio, A., \& Collepardi, M. (2004). MSWI Ashes as Mineral Additions in Concrete, Cement and Concrete Research 34(10): 1899-1906. https://doi.org/10.1016/j.cemconres.2004.02.001

Bethanis, S., Cheeseman, C. R., \& Sollars, C. J. (2002). Properties and microstructure of sintered incinerator bottom ash, Ceramic International 28: 881-886. https://doi.org/10.1016/S0272-8842(02)00068-8

Brocken, H. \& Nijland, T. G. (2004). White efflorescence on brick masonry and concrete masonry blocks, with special emphasis on sulfate efflorescence on concrete blocks, Construction and Building Materials 18(5): 315-323. https://doi.org/10.1016/j.conbuildmat.2004.02.004

Cao, Y., Liu, R., Xu, Y., Ye, F., Xu, R., \& Han, Y. (2019). Effect of $\mathrm{SiO}_{2}, \mathrm{Al}_{2} \mathrm{O}_{3}$ and $\mathrm{CaO}$ on characteristics of lightweight aggregates produced from MSWI bottom ash sludge (MSWI-BAS). Construction and Building Materials: 205 (30): 368-376. https://doi.org/10.1016/j.conbuildmat.2019.01.104

Cation Exchange Capacity (CEC). (2007). Cornell University Cooperative Extension. Prieiga per internetą:

$<\mathrm{http}$ //nmsp.cals.cornell.edu/publications/factsheets/factsheet22.pdf $>$

Celary, P. \& Sobik-Szołtysek, J. (2014). Vitrification as an alternative to landfilling of tannery sewage sludge, Waste Management 34: 2520-2527.

https://doi.org/10.1016/j.wasman.2014.08.022

Chao-Lung, H. \& Trong-Phuoc, H. (2015). Investigation into the use of unground rice husk ash to produce eco-friendly construction bricks, Construction and Building Materials 93: 335-341. https://doi.org/10.1016/j.conbuildmat.2015.04.061

Cheeseman, C. R., Makinde, A., \& Bethanis. S. (2005). Properties of lightweight aggregate produced by rapid sintering of incinerator bottom ash, Resources, Conservation and Recycling 43(2): 147-162.

https://doi.org/10.1016/j.resconrec.2004.05.004

Cheeseman, C. R., Monteiro da Rocha, S., Sollars, C., Bethanis, S., \& Boccaccini, A. R. (2003). Ceramic processing of incinerator bottom ash, Waste Management 23: 907-916. https://doi.org/10.1016/S0956-053X(03)00039-4

Chen, W-Sh., Chang, F-Ch., Shen, Y-H., Tsai, M-Sh., \& Ko, Ch-H. (2012). Removal of chloride from MSWI fly ash. Journal of Hazardous Materials 237-238, 116-120. https://doi.org/10.1016/j.jhazmat.2012.08.010

Chen, X., Bi, Y., Zhang, H., \& Wang, J. (2016). Chlorides Removal and Control through Water-washing Process on MSWI Fly Ash, Procedia Environmental Sciences 31, 560-566. https://doi.org/10.1016/j.proenv.2016.02.086

Chimenos, J. M., Fernandez, A. I., Cervantes, A., Miralles, L., Fernandez, M. A., \& Espiell, F. (2005). Optimizing the APC residue washing process to minimize the release of chloride and heavy metals, Waste Management 25, 686-693. https://doi.org/10.1016/j.wasman.2004.12.014 
Chimenos, J. M., Segarra, M., Fernández, M. A., \& Espiell, F. (1999). Characterization of the bottom ash in municipal solid waste incinerator, Journal of Hazardous Materials 64(3): 211-222. https://doi.org/10.1016/S0304-3894(98)00246-5

Cimmers, A., Svinka, R., Svinka V., \& Moertel, H. (2005). Pore structure of porous building ceramic materials from illite containing raw materials, Ce. Ca. 35: 9-13.

Colangelo, F., Messina, F., \& Cioffi, R. (2015). Recycling of MSWI fly ash by means of cementitious double step cold bonding palletisation: Technological assessment for the production of lightweight artificial aggregates, Journal of Hazardous Materials 299: 181-191. https://doi.org/10.1016/j.jhazmat.2015.06.018

Cornelis, G., Van Gerven, T., \& Vandecasteele, C. (2012). Antimony leaching from MSWI bottom ash: modelling of the effect of $\mathrm{pH}$ and carbonation, Waste Management 32(2): 278-286. https://doi.org/10.1016/j.wasman.2011.09.018

Council decision of 19 December 2002 establishing criteria and procedures for the acceptance of waste at landfills pursuant to Article 16 of and Annex II to Directive 1999/31/EC (2003/33/EC)

de Almeida J. V. (2015). Ceramics. In: Gonçalves M., Margarido F. (eds) Materials for Construction and Civil Engineering. Springer, Cham. 303-334. https://doi.org/10.1007/978-3-319-08236-3_7

Del Valle-Zermeno, R., Formosa, J., Prieto, M., Nadal, R., Niubo, M., \& Chimenos, J. M. (2014). Pilot-scale road subbase made with granular material formulated with MSWI bottom ash and stabilized APC fly ash: Environmental impact assessment, Journal of Hazardous Materials 266(15): 132-140.

https://doi.org/10.1016/j.jhazmat.2013.12.020

Deng, Y., Gong, B., Chao, Y., Dong, T., Yang, W., Hong, M., Shi, X., Wang, G., Jin, Y., \& Chen, Z-G. (2018). Sustainable utilization of municipal solid waste incineration fly ash for ceramic bricks with eco-friendly biosafety, Materials Today Sustainability 1-2: 32-38. https://doi.org/10.1016/j.mtsust.2018.11.002

Dijkstra, J. J., Van Zomeren, A., Meeussen, J. C. L., \& Comans, R. N. (2006). Effect of accelerated aging of MSWI bottom ash on the leaching mechanisms of copper and molybdenum, Environmental Science Technology 40: 4481-4487. https://doi.org/10.1021/es052214s

DIN 38414-2:1985-11 “German standard methods for the examination of water, waste water and sludge; sludge and sediments (group $S$ ); determination of water content, of dry residue and of solids content (S 2)".

Dondi, M., Fabbri, B., Guarini, G., Marsigli, M., \& Mingazzini, C. (1997). Soluble salts and efflorescence in structural clay products; A scheme to predict the risk of efflorescence, Boletin de la Sociedad Espanola de Ceramica y Vidrio articulo 36(6): 619-629.

https://pdfs.sematicscholar.org/cd11/f680c8dbb87c3a16781d97f4a696ffd74e35.pdf 
Dondi, M., Guarini G., Raimondo M., \& Ruffini, A. (2002). Orimulsion fly ash in clay bricks - part 3: chemical stability of ash-bearing products, Journal of the European Ceramic Society 22(11): 1749-1758. https://doi.org/10.1016/S09552219(01)00495-2

Dondi, M., Guarini, G., \& Raimondo, M. (1999). Trends in the Formation of Crystalline and Amorphous Phase during the Firing of Clay bricks, Tail and Brick Industry 15: 176-183. Prieiga per internetą:

$<$ https://www.researchgate.net/profile/Michele_Dondi/publication/268506397_Trends_in_the_Formation_of_Crystalline_and_Amorphous_Phases_During_Firing_of_Clay_Bricks/links $/ 5 \overline{4} 6 \overline{\mathrm{d}} 03 \mathrm{db} 0 \mathrm{cf} 2 \mathrm{a} 7 \overline{4} 92 \mathrm{c} 55 \mathrm{~b} 040 . \mathrm{pdf}>$

Dou, X., Ren, F., Nguyen, M. Q., Ahamed, A., Yin, K., Chan, W. P., \& Wei-Chung Chang, V. (2017). Review of MSWI bottom ash utilization from perspectives of collective characterization, treatment and existing application, Renewable and Sustainable Energy Reviews 79: 24-38. https://doi.org/10.1016/j.rser.2017.05.044

Eliche-Quesada, D., Felipe-Seséa, M. A., Moreno-Molina, A. J., Franco, F., \& Infantes-Molina A. (2017). Investigation of using bottom or fly pine-olive pruning ash to produce environmental friendly ceramic materials. Applied Clay Science 135: 333346. https://doi.org/10.1016/j.clay.2016.10.015

EN 1484:2019-04 "Water analysis - Guidelines for the determination of total organic carbon (TOC) and dissolved organic carbon (DOC)".

EN ISO 10304-1:2009 "Water quality - Determination of dissolved anions by liquid chromatography of ions - Part 1: Determination of bromide, chloride, fluoride, nitrate, nitrite, phosphate and sulfate".

EN ISO 11885:2009-09 "Water quality - Determination of selected elements by inductively coupled plasma optical emission spectrometry (ICP-OES) (ISO 11885:2007)".

Europe Waste Catalog. Guidance on using the European Waste Catalogue (EWC) to code waste November 2015.

Faria, K., Gurgel, R., \& Holanda, J. (2012). Recycling of sugarcane bagasse ash waste in the production of clay bricks, Journal Environmental Management 101: 7-12. https://doi.org/10.1016/j.jenvman.2012.01.032

Fraissler, G., Jöller, M., Mattenberger, H., Brunner, T., \& Obernberger, T. (2009). Thermodynamic equilibrium calculations concerning the removal of heavy metals from sewage sludge ash by chlorination, Chemical Engineering and Processing: Process Intensification 48 (1): 152-164. https://doi.org/10.1016/j.cep.2008.03.009

Freyssinet, P., Piantone, P., Azaroual, M., Itard, Y., Clozel-Leloup, B., Guyonnet, D., $\&$ Baubron, J. C. (2002). Chemical changes and leachate mass balance of municipal solid waste bottom ash submitted to weathering, Waste Management 22(2): 159-172. https://doi.org/10.1016/S0956-053X(01)00065-4

Garcia-Lodeiro, I., Carcelen-Taboada, V., Fernández-Jiménez, A., \& Palomo, A. (2016). Manufacture of hybrid cements with fly ash and bottom ash from a municipal 
solid waste incinerator, Construction and Building Materials 105(15): 218-226. https://doi.org/10.1016/j.conbuildmat.2015.12.079

Garcia-Ubaque, C. A., Moreno-Pirajan, J. C., \& Giraldo-Gutierrez, L. (2007). Stabilization/solidification of ashes in clay used in the manufacturing of ceramic bricks, Waste Management and Research 25(4): 352-362.

https://doi.org/10.1177/0734242X07077820

Gines, O., Chimenos, J. M., Vizcarro, A., Formosa, J., \& Rosell, J. R. (2009). Combined use of MSWI bottom ash and fly ash as aggregate in concrete formulation: Environmental and mechanical considerations, Journal of Hazardous Materials 169: 643-650. https://doi.org/10.1016/j.jhazmat.2009.03.141

Giro-Paloma, J., Ribas-Manero, V., Maldonado-Alameda, A., Formosa, J., \& Chimenos, J. M. (2017). Use of municipal solid waste incineration bottom ash and crop byproduct for producing lightweight aggregate, IOP Conference Series: Materials Science and Engineering 251(1): 121-126.

https://doi.org/10.88/1757-899X/251/1/012126

Guidance on using the European Waste Catalogue (EWC) to code waste. 2015. 55 p. Haiying, Z., Youcai, Z., \& Jingyu, Q. (2007). Study on use of MSWI fly ash in ceramic tile, Journal of Hazardous Materials 141: 106-114. https://doi.org/10.1016/j.jhazmat.2006.06.100

Haiying, Z., Youcai, Z., \& Jingyu, Q. (2011). Utilization of municipal solid waste incineration (MSWI) fly ash in ceramic brick: Product characterization and environmental toxicity, Waste Management 31(2): 331-341. https://doi.org/10.1016/j.wasman.2010.10.017

Hall, C. \& Hoff, W. (2002). Water transport in Brick, Stone and Concrete. Taylor and Francis Group. London and New York. 336 p.

He, P-J., Zhang, H., Zhang, C-G., \& Lee, D-J. (2004). Characteristics of air pollution control residues of MSW incineration plant in Shanghai, Journal of Hazardous Materials 2004, 116, 229-237. https://doi.org/10.1016/j.jhazmat.2004.09.009

Hewamanna, R., Sumithrarachchi, C. S., Mahawatte, P., Nanayakkara, H. L. C., \& Ratnayake, H. C. (2001). Natural radioactivity and gamma dose from Sri Lankan clay bricks used in building construction, Applied Radiation and Isotopes 54: 365-369. https://doi.org/10.1016/S0969-8043(00)00107-X

Yang, J., Xiao, B., \& Boccaccini, A. R. (2009). Preparation of low melting temperature glass-ceramics from municipal waste incineration fly ash, Fuel 88: 1275-1280. https://doi.org/10.1016/j.fuel.2009.01.019

Yang, S., Saffarzadeh, A., Shimaoka, T., \& Kawano, T. (2014). Existence of Cl in municipal solid waste incineration bottom ash and dechlorination effect of thermal treatment, Journal of Hazardous Materials 267: 214-220. https://doi.org/10.1016/j.jhazmat.2013.12.045 
Yanga, Z., Tianbc, S., Liua, L., Wanga, X., \& Zhangbd, Z. (2018). Recycling ground MSWI bottom ash in cement composites: Long-term environmental impacts, Waste Management 78: 841-848. https://doi.org/10.1016/j.wasman.2018.07.002

Ye, N., Chen, Y., Yang, Y., Liang, S., Hu, Y., Xiao, B., Huang, Q., Shi, Y., Hu, J., \& $\mathrm{Wu}, \mathrm{X}$. (2016). Co-disposal of MSWI fly ash and Bayer red mud using an one-part geopolymeric system, Journal of Hazardous Materials 318: 70-78. https://doi.org/10.1016/j.jhazmat.2016.06.042

ISO 10694:1995 , Soil quality - Determination of organic and total carbon after dry combustion (elementary analysis) “

ISWA, 2006. Management of Bottom Ash from WTE Plants, Working Group on Thermal Treatment of Waste. An overview of management options and treatment methods. https://www.iswa.org/uploads/tx_iswaknowledgebase/Bottom_ash_from_WTE_2006_01.pdf

Izquierdo, M., López-Soler, A., Ramonich, E. V., Barra, M., \& Querol, X. (2002). Characterisation of bottom ash from municipal solid waste incineration in Catalonia, J. Chem. Technol. Biotechnology 77:576-583. https://doi.org/10.1002/jctb.605

Jin, M., Zheng, Z., Sun, J., Chen, L., \& Jin, Z. (2016). Resistance of metakaolinMSWI fly ash based geopolymer to acid and alkaline environments, Journal of NonCrystalline Solids 450: 116-122. https://doi.org/10.1016/j.jnoncrysol.2016.07.036

Jordan, M. M., Montero, M. A., Rincon-Mora, B., Rincon, J. M., \& Sanfeliu, T. (2015). Rustic ceramic covering tiles obtained by recycling of marble residues and msw fly ash, Fresenius Environmental Bulletin 24(2): 533-538. http://repositori.uji.es/xmlui/handle/10234/166955

Keppert, M., Pavlík, Z., Tydlitát, V., Volfová, P., Švarcová, S., Šyc, M., \& Černý, R. (2012). Properties of municipal solid waste incineration ashes with respect to their separation temperature. Waste Management 30, 1041-1048. https://doi.org/10.1177/0734242X12448513

Kersch, C., van der Kraan, M., Woerlee, G. F., \& Witkamp, G. J. (2002). Municipal waste incinerator fly ash: supercritical fluid extraction of metals, Juornal of Chemical Technology and Biotechnology 77: 256-259. https://doi.org/10.1002/jctb.589

Kirk, D. W., Chris, C., Chan, Y., \& Marsh, H. (2002). Chromium behaviour during thermal treatment of msw fly ash, Journal of Hazardous Materials 90 (1): 39-49. https://doi.org/10.1016/S0304-3894(01)00328-4

Kizinievič, V. 2008. Technologinių veiksnių poveikis keraminių mūro gaminių atsparumui šalčiui. Daktaro disertacija. Vilnius.

Koroth, S. R., Feldman, D., \& Fazio, P. (1998). Development of new durability index for clay bricks, J. Archit. Eng. 4: 87-93.

Lamers, F. 2015. Treatment of bottom ashes of waste to energy installations: State of the art, Waste management: Waste-to-energy 5: 271-290. 
Leaching Characteristics of Building and Solid Waste Material, Leaching Tests, Determination of the Leaching of Inorganic Components from the Granular Materials with the Column Test," Nederland's Norm NEN 7343, (1995).

Levitskii, I. A., Pavlyukevich, Yu. G., Bogdan, E. O., \& Kichkailo, O. V. (2013). Use of electroplating sludge for ceramic manufacture, Glass Ceramics 70: 83-88. https://doi.org/10.1007/s10717-013-9514-9

Li, X., Chen, Q., Zhou, Y., Tyrer, M., \& Yu, Y. (2014). Stabilization of heavy metals in MSWI fly ash using silica fume, Waste Management 34 (12): 2494-2504. https://doi.org/10.1016/j.wasman.2014.08.027

Lietuvos Respublikos Aplinkos ministras. Isakymas dèl atlieku deginimo ịrenginiuose ir bendro atlieku deginimo ïrenginiuose susidariusiu pelenu ir dugno pelenu tvarkymo reikalavimu patvirtinimo. $2016 \mathrm{~m}$. lapkričio $25 \mathrm{~d}$. Nr. D1-805. Vilnius, 2016. p. 10.

Lietuvos Respublikos sveikatos apsaugos ministerija. Isakymas dèl Lietuvos higienos normos HN 85:2011 "Gamtine apšvita. radiacinés saugos normos" patvirtinimo, Nr. V-890, 2011-10-07, Žin., 2011, Nr. 124-5917 (2011-10-15).

Lietuvos statistikos departamentas (2020). Oficialios statistikos portalas. https://osp.stat.gov.lt/lietuvos-aplinka-zemes-ukis-ir-energetika-2020/energetika/energijos-balansas

Lin, C-F., Wu, C-H., \& Ho, H-M. (2006). Recovery of municipal waste incineration bottom ash and water treatment sludge to water permeable pavement materials, Waste Management 26(9): 970-978. https://doi.org/10.1016/j.wasman.2005.09.014

Lin, K. L. 2006. Feasibility study of using brick made from municipal solid waste incinerator fly ash slag, Journal of Hazardous Materials 137: 1810-1816. https://doi.org/10.1016/j.jhazmat.2006.05.027

Liu, H., Zhao, X., Yin, H., Chen, J., \& Zhang, N. (2018). Intermediate-calcium based cementitious materials prepared by MSWI fly ash and other solid wastes: hydration characteristics and heavy metals solidification behaviour, Journal of Hazardous Materials 349: 262-271. https://doi.org/10.1016/j.jhazmat.2017.12.072

LST 1985:2006 Keraminių mūro gaminių atsparumo šalčiui nustatymas.

LST EN 12457-4:2003. Atlieku apibūdinimas. Ǐ̌plovimas. Iš grūdètu atlieku išplautu medžiagu ir dumblo sudèties atitikties tyrimas. 4 dalis. Vienpakopis partijos (tyrinio) tyrimas, kai skysčio ir kietosios medžiagos santykis $10 \mathrm{l} / \mathrm{kg}$ ir dalelių dydis mažesnis kaip 10 mm (dydị mažinant arba nemažinant).Vilnius, 2003.

LST EN 772-1:2011+A1:2015 Mūro gaminiu bandymo metodai. 1 dalis. Gniuždymo stiprio nustatymas.

LST EN 772-11:2011 Mūro gaminiu bandymo metodai. 11 dalis. Užpildu betono, autoklavinio akytojo betono, dirbtinio ir gamtinio akmens mūro gaminiu kapiliarinio vandens igerties ir keraminiu müro gaminiu pradinés vandens igerties spartos nustatymas. 
LST EN 772-13:2003 Mūro gaminių bandymo metodai. 13 dalis. Mūro gaminiu (išskyrus gamtinio akmens) neto ir tariamojo (bruto) sausojo tankio nustatymas.

LST EN 772-21:2011 Mūro gaminių bandymo metodai. 21 dalis. Keraminiu ir silikatiniu mūro gaminių vandens įmirkio nustatymas panardinant juos $i \grave{s}$ šltą vandenị.

LST EN 772-22:2019 Mūro gaminiu bandymo metodai. 22 dalis. Keraminiu mūro gaminiu atsparumo šaldymui ir atšildymui nustatymas.

LST EN 772-5:2016 Mūro gaminiu bandymo metodai. 5 dalis. Keraminiu mūro gaminiu aktyviuju tirpiuju drusku kiekio nustatymas Methods of test for masonry units - Part 5: Determination of the active soluble salts content of clay masonry units EN 772-5:2016

Lu, X., \& Shih, K. (2012). Metal stabilization mechanism of incorporating lead-bearing sludge in kaolinite-based ceramics, Chemosphere 86: 817-821. https://doi.org/10.1016/j.chemosphere.2011.11.043

Lu, X., \& Shih, K. (2015). Formation of lead-aluminate ceramics: Reaction mechanisms in immobilizing the simulated lead sludge, Chemosphere 138: 156-163. https://doi.org/10.1016/j.chemosphere.2015.05.090

Lubelli, B., van Hees, R. P. J., \& Groot, C. J. W. P. (2004). The role of sea salts in the occurrence of different damage mechanisms and decay patterns on brick masonry, Construction and Building Materials 18: 119-124.

https://doi.org/10.1016/j.conbuildmat.2003.08.017

Malinauskaite, J., Jouhara, H., Czajczynska, D., Stanchev, P., Katsou, E., Rostowski, P., Thorne, R. J., Colon, J., Ponsal, S., Al-Mansour, F., Anguilano, L., Krzyzynska, R., Lopez, C. I., Vlasopoulos, A., Spencer, N. (2017). Municipal solid waste management and waste-to-energy in the context of a circular economy and energy recycling in Europe, Energy 141:2013-2044.

https://doi.org/10.1016/j.energy.2017.11.128

Mao, L., Cui, H., An, H., Wang, B., Zhai, J., Zhao, Y., \& Li, Q. (2016). Stabilization of simulated lead sludge with iron sludge via formation of $\mathrm{PbFe} 12 \mathrm{O} 19$ by thermal treatment, Chemosphere 117:745-752.

https://doi.org/10.1016/j.chemosphere.2014.08.027

Mao, L., Cui, H., An, H., Wang, B., Zhai, J., Zhao, Y., \& Li, Q. (2019). Effects of electroplating sludge introduction on the morphology, mineral phase and porosity evolution of fired clay bricks, Constraction and Building Materials 211:130-138. https://doi.org/10.1016/j.conbuildmat.2019.03.251

Mehu, J., Perrodin, Y., Sarrazin, B., \& Veron, J. (1991). French Approach Towards the Evaluation of Monolithic and Solidified Waste: Development of a New Leaching Procedure, Studies in Environmental Science 48: 293-300. https://doi.org/10.1016/S0166-1116(08)70413-8

Morf, L. S., Gloor, R., Haag, F., Haupt, M., Skutan, S., Di Lorenzo, F., \& Bön, D. (2013). Precious metals and rare earth elements in municipal solid waste - Sources 
and fate in a Swiss incineration plant, Waste Management 33(3): 634-644. https://doi.org/10.1016/j.wasman.2012.09.010

Mulder, E. (1996). Pre-treatment of MSWI fly ash for useful application, Waste Management 16, 181-184. https://doi.org/10.1016/S0956-053X(96)00040-2

Nogales, R., Delgado, G., Quirantes, M., Romero, M., Romero, E., \& Molina-Alcaide, E. (2011). Characterization of olive waste ashes as fertilizer, Recycling of Biomass Ashes. In: Insam H., Knapp B. (eds) Springer, Berlin, Heidelberg. 57-68. https://doi.org/10.1007/978-3-642-19354-5_5

Nowak, B., Aschenbrenner, P. \& Winter, F. (2013). Heavy metal removal from sewage sludge ash and municipal solid waste fly ash - A comparison, Fuel Processing Technology 105: 195-201. https://doi.org/10.1016/j.fuproc.2011.06.027

Pan, J. R., Huang, C., Kuo, J-J., \& Lin, S-H. (2008). Recycling MSWI bottom and fly ash as raw materials for Portland cement, Waste Management 28: 1113-1118. https://doi.org/10.1016/j.wasman.2007.04.009

Panjaitan, S. R. N. (2014). The effect of lime content on the bearing capacity and swelling potential of expansive soil, Journal of Civil Engineering Research 4: 89-95.

Piantone, P., Bodénan, F., \& Chatelet-Snidaro, L. (2004). Mineralogical study of secondary mineral phases from weathered MSWI bottom ash: implications for the modelling and trapping of heavy metals, Applied Geochemistry 19(2): 1891-1904. https://doi.org/10.1016/j.apgeochem.2004.05.006

Qian, G., Cao Y., Chui, P., \& Tay, J. (2006). Utilization of MSWI fly ash for stabilization/solidification of industrial waste sludge, Journal of Hazardous Materials 129: 274-281. https://doi.org/10.1016/j.jhazmat.2005.09.003

Rambaldi, E., Esposito, L., Andreola, F., Barbieri, L., Lancellotti, I., \& Vassura, I. (2010). The recycling of MSWI bottom ash in silicate based ceramic, Ceramics International 36(8): 2469-2476. https://doi.org/10.1016/j.ceramint.2010.08.005

Rem, P. C., De Vries, C., van Kooy, L. A., Bevilacqua, P., \& Reuter, M. A. (2004). The Amsterdam pilot on bottom ash, Minerals Engineering 17(2): 363-365. https://doi.org/10.1016/j.mineng.2003.11.009

Remond, S., Bentz, D. P., \& Pimienta, P. (2002). Effects of the incorporation of municipal solid waste incineration $\mathrm{n}$ fly ash in cement pastes and mortars, Cement Concrete Research 32: 565-576. https://doi.org/10.1016/S0008-8846(01)00722-0

Rendek, E., Ducom, G., \& Germain, P. (2006). Carbon dioxide sequestration in municipal solid waste incinerator (MSWI) bottom ash, Journal of Hazardous Materials 128(1): 73-79. https://doi.org/10.1016/j.jhazmat.2005.07.033

Rodriguez-Navarro, C. \& Doehne, E. (1999). Salt weathering: influence of evaporation rate, supersaturation and crystallization pattern, Earth Surface Processes and Landforms Earth Surface Processes and Landforms 24: 191-209. https://doi.org/10.1002/(SICI)1096-9837(199903)24:3<191::AID-

ESP942>3.0.CO;2-G 
Sabbas, T., Mostbauer, P., Rautner, T., \& Lechner, P. (2001). A prediction model for the assessment of the middle and long-term emission flux of inorganic wastes, Proc. ISWA World Congress 2001, Stavanger, Norway, $2001 \mathrm{a}$.

Sadūnas, A. (1997). Aliumosilikatų dirbinių ilgaamžiškumas Vilnius, VPU leidykla, UDK 539.3/6, ISBN 9986-869-09-9; 252 psl.

Sadūnas, A. (1999). Aliumosilikatų degimas redukuojančių-oksiduojančių dujų terpejje. Vilnius, Vilniaus Pedagoginis universitetas, ISBN 9986-869-51-X; 188 psl.

Saikia, N., Kato, S., \& Kojima, T. (2007). Production of cement clinkers from municipal solid waste incineration (MSWI) fly ash, Waste Management 27: 1178-1189. https://doi.org/10.1016/j.wasman.2006.06.004

Sánchez de Rojas, M. I., Marín, F. P., Frías, M., Valenzuela, E., \& Rodríguez, O. (2011). Influence of freezing test methods, composition and microstructure on frost durability assessment of clay roofing tiles, Construction and Building Materials 25(6): 2888-2897. https://doi.org/10.1016/j.conbuildmat.2010.12.041

Schabbach, L. M., Andreola, F., Barbieri, L., Lancellotti, I., Karamanova, E., Ranguelov, B., \& Karamanov, A. (2012). Post-treated incinerator bottom ash as alternative raw material for ceramic manufacturing, Journal of Europe Ceramic Society 32: 2843-2852. https://doi.org/10.1016/j.jeurceramsoc.2012.01.020

Schabbach, L. M., Andreola, F., Lancellotti, I., \& Barbieri. L. (2011). Minimization of $\mathrm{Pb}$ content in a ceramic glaze by reformulation the composition with secondary raw materials, Ceramic International 37: 1367-1375.

https://doi.org/10.1016/j.ceramint.2010.12.009

Shi, H-S., \& Kan, L-L. (2009). Leaching behavior of heavy metals from municipal solid wastes incineration (MSWI) fly ash used in concrete, Journal of Hazardous Materials 164(2-3): 750-754. https://doi.org/10.1016/j.jhazmat.2008.08.077

Shih, P-H., Chang, J-E., \& Chiang, L-C. (2003). Replacement of raw mix in cement production by municipal solid waste incineration ash, Cement and Concrete Research 33: 1831-1836. https://doi.org/10.1016/S0008-8846(03)00206-0

Silva, R. V., de Brito, J., Lynn, C. J., \& Dhir, R. K. (2017). Use of municipal solid waste incineration bottom ashes in alkali-activated materials, ceramics and granular applications: a review, Waste Management 68: 207-220.

https://doi.org/10.1016/j.wasman.2017.06.043

Silva, R. V., de Brito, J., Lynn, C. J., \& Dhir, R. K. (2019). Environmental impacts of the use of bottom ashes from municipal solid waste incineration: A review, $R e$ sources, Conservation and Recycling 140: 23-35. https://doi.org/10.1016/j.resconrec.2018.09.011

Smith, A. S., Bingel, P., \& Bown, A. (2016). 11 - Sustainability of masonry in construction, Sustainability of Construction Materials (Second Edition), Woodhead Publishing Series in Civil and Structural Engineering, 245-282.

https://doi.org/10.1016/B978-0-08-100370-1.00011-1 
Sveda, M. (2001). Frost resistance of brick knowledge about the relationship between pore structure and frost resistance is the first step to the production of high frostresistance brick products, Am. Ceram. Soc. Bull. 80: 46-48.

Tang, Y., Shih, K., \& Chan, K. (2010). Copper aluminate spinel in the stabilization and detoxification of simulated copper-laden sludge, Chemosphere 80: 375-380. https://doi.org/10.1016/j.chemosphere.2010.04.048

Tang, Y., Shih, K., \& Chan, K. (2014). Alumina polymorphs affect the metals immobilization effect when beneficially using copper-bearing industrial sludge for ceramics, Chemosphere 117: 575-581.

https://doi.org/10.1016/j.chemosphere.2014.08.065

Tang, J., Petranikova, M., Ekberg, C., \& Steenari, B. M. (2017). Mixer-settler system for the recovery of copper and zinc from MSWI fly ash leachates: An evaluation of a hydrometallurgical process, Journal of Cleaner Production 148: 595-605. https://doi.org/10.1016/j.jclepro.2017.02.015

Tang, P., Florea, M. V. A., Spiesz, P., \& Brouwers, H. J. H. (2015). Characteristics and application potential of municipal solid waste incineration (MSWI) bottom ashes from two waste-to-energy plants, Construction and Building Materials 83: 77-94. https://doi.org/10.1016/j.conbuildmat.2015.02.033Get rights and content

Taurino, R., Karamanov, A., Rosa, R., Karamanova, E., Barbieri, L., Atanasova-Vladimirova, S., Avdeev, G., \& Leonelli, C. (2017a). New ceramic materials from MSWI bottom ash obtained by an innovative microwave-assisted sintering process, Journal of the European Ceramic Society 37(1): 323-331.

https://doi.org/10.1016/j.jeurceramsoc.2016.08.011

Taurino, R., Karamanova, E., Barbieri, L., Atanasova-Vladimirova, S., Andreola, F., \& Karamanov, A. (2017b). New fired bricks based on municipal solid waste incinerator bottom ash, Waste Management \& Research 35(10): 1055-1063. https://doi.org/10.1177/0734242X17721343

The7 th Environmental Action Programme to 2020 (AEP, 2020).

Tsui, N., Flatt, R. J., \& Scherer, G. W. (2003). Crystallization damage by sodium sulphate, Journal of Cultural Heritage 4:109-15. https://doi.org/10.1016/S12962074(03)00022-0

Van Herck, P., Van der Bruggen, B., Vogels, G., \& Vandecasteele, C. (2000). Application of computer modelling to predict the leaching behaviour of heavy metals from MSWI fly ash and comparison with a sequential extraction method, Waste Management 20: 203-210. https://doi.org/10.1016/S0956-053X(99)00321-9

Vegas, I., Ibañez, J. A., San José, J. T., \& Urzelai, A. (2008). Construction demolition wastes, Waelz slag and MSWI bottom ash: A comparative technical analysis as material for road construction, Waste Management 28(3): 565-574. https://doi.org/10.1016/j.wasman.2007.01.016 
Vichaphund, S., Jiemsirilers, S., \& Thavorniti, P. (2012). Sintering of municipal solid waste incineration bottom ash, Journal of Engineering Science 8: 51-59. Prieiga per internetą: http://web.usm.my/jes/8_2012/JES-ART5-51-59.pdf

Vilniaus kogeneracinès jègainès pristatymas bei pelenų susidarymas (2017).

Wan, C. (2017). Electrochemical upgrading of different ashes for use in production of bricks. Thesis PhD. Technical University of Denmark, Department of Civil Engineering, 2017. ID: 2394007636.

Wang, H., Fan, X., Wang, Y., Li, W., Sun, Y., Zhan, M., \& Wu, G. (2018). Comparative leaching of six toxic metals from raw and chemically stabilized MSWI fly ash using citric acid, Journal of Environmental Management 208: 15-23. https://doi.org/10.1016/j.jenvman.2017.11.071

Wang, L., Chen, Q., Jamro, I. A., Li, R. D., \& Baloch, H. A. (2016). Accelerated coprecipitation of lead, zinc and copper by carbon dioxide bubbling in alkaline municipal solid waste incinerator (MSWI) fly ash wash water, RSC Advances 6: 2017320186. https://doi.org/10.1039/C5RA23889G

Wei, Y., Saffarzadeh, A., Shimaoka, T., Zhao, C., Peng, X., \& Gao, J. (2014). Geoenvironmental weathering/deterioration of landfilled MSWI-BA glass, Journal of Hazardous Materials 278: 610-619. https://doi.org/10.1016/j.jhazmat.2014.05.093

Wei, Y., Shimaoka, T., Saffarzadeh, A., \& Takahashi, F. (2011). Mineralogical characterization of municipal solid waste incineration bottom ash with an emphasis on heavy metal-bearing phase, Journal of Hazardous Material 187: 534-543. https://doi.org/10.1016/j.jhazmat.2011.01.070

Wongsa, A., Boonserm, K., Waisurasingha, C., Sata, V., \& Chindaprasirt, P. (2017). Use of municipal solid waste incinerator (MSWI) bottom ash in high calcium fly ash geopolymer matrix, Journal of Cleaner Production 148: 49-59. https://doi.org/10.1016/j.jclepro.2017.01.147

Wu, S., Xu, Y., Sun, J., Cao, Z., Zhou, J., Pan, Y., \& Qian, G. (2015). Inhibiting evaporation of heavy metal by controlling its chemical speciation in MSWI fly ash, Fuel 158: 764-769. https://doi.org/10.1016/j.fuel.2015.06.003

Wunsch, P., Greilinger, C., Bieniek, D., \& Kettrup, A. (1996). Investigation of the binding of heavy metals in thermally treated residues from waste incineration, Chemosphere 32: 2211-2218. https://doi.org/10.1016/0045-6535(96)00123-3

Zhu, X., Yuan, Y., Li, L., Liu, D., \& Ling, J. (2016). Utilize nano-scale metrology techniques to investigate mechanical, structural, and chemical heterogeneity of mixtures contained incineration bottom ash aggregate, Construction and Building Materials 127: 627-642. https://doi.org/10.1016/j.conbuildmat.2016.10.033

ГОСТ 9169-75. Сырье глинистое для керамической промышленности. Классификация. Clayish materials for ceramic industry. Classification.

Мачюлайтис, Р. (1997). Морозостойкость и долговечность изделий фасадной керамики. Вильнюс: Техника. 307. 
Вахрамова, Г. П., Зимнухова Т. Б., Винокуров, В. Н. (2000). Научные труды Астраханского ГТУ: 2(1): 81-84.

Павлов, В. Ф. (1977). Физико-химические основы обжига изделий строительной керамики. Москва: Стройиздат. 224. 


\section{Autorès mokslinių publikaciju disertacijos tema sąrašas}

\section{Straipsniai recenzuojamuose mokslo žurnaluose}

Voišnienè, V., Kizinievič, O., \& Kizinievič, V. (2020). Effect of municipal solid waste incineration fly ash on the properties, microstructure and durability of clay bricks, Ceramics-Silikáty 64 (4). 423-433. Prague: University of Chemistry and Technology. ISSN 0862-5468. https://doi.org/10.13168/cs.2020.0030

Kizinievič, O., Voišnienė, V., Kizinievič, V. \& Škamat, J. (2019). Effect of municipal solid waste incineration fly ash on the properties, durability, and environmental toxicity of fired aluminosilicates, Glass and ceramics 76 (7-8): 307-310. ISSN 0361-7610. https://doi.org/10.1007/s10717-019-00189-0

\section{Straipsniai kituose leidiniuose}

Voišnienè, V., Kizinievič, O., \& Kizinievič, V. (2019a). Recycling municipal solid waste incineration (MSWI) fly ash as addition for clay brick. IOP conference series: Materials science and engineering. Bristol: IOP Publishing. 660 (2019), 1-7. ISSN 1757-8981. https://doi:10.1088/1757-899X/660/1/012065

Voišnienè, V., Kizinievič, O., \& Kizinievič, V. (2019b). Feasibility study of using clay bricks made from municipal solid waste incinerator (MSWI) fly ash, in $4^{\text {th }}$ World Multidisciplinary Civil Engineering-Architecture-Urban Planning Symposium (WMCAUS 
2019), June 17-21, 2019, Prague, Czech Republic. Bristol: IOP Publishing Ltd. 603 (2019), 1-7. ISSN 1757-8981. https://doi:10.1088/1757-899X/603/2/022058

Voišnienè, V., Kizinievič, O., Kizinievič, V., \& Malaiškienė, J. (2019c). Production of fired clay brick from municipal solid waste incinerator fly ash. The 13th international conference "Modern building materials, structures and techniques", 16-17 May, 2019, Vilnius, Lithuania. Vilnius: VGTU Press, 2019, p. 188-193. https://doi:10.3846/mbmst.2019.149

Voišnienè, V., Kizinievič, O., Kizinievič, V., \& Malaiškienè, J. (2018). Utilization of municipal solid waste incineration (MSWI) fly ash in clay brick. MALTOVINY 2018. XVII. Odborná konference o védě, výzkumu a aplikacich v oboru maltovin, Vysoké učeni technické v Brné, Fakulta stavebni, 6. 12. 2018: sbornik konference $=$ Binders 2018. Brno University of Technology Faculty of Civil Engineering, December 6, 2018: proceedings. Brno: Brno University of Technology, 32-38. ISBN-978-8021-45-567-2.

Voišnienè, V., \& Kizinievič, O. (2018). Research of fly ash and slag (Bottom Ash) from municipal waste incineration. The possibilities of secondary use. Архитектурно-строительный комплекс: проблемы, перспективы, инновации: электронный сборник статей международной научной конференции, посвященной 50-летию Полоикого государственного университета (Новополоцк, 5-6 апреля 2018 г.). Новополоцк: Полоцкий государственный университет, 163-166. ISBN-978-9855-31-608-5.

\section{Patentas}

Kizinievič, O., Voišnienè, V., \& Kizinievič, V. (2020). Keraminiu gaminiu su dugno pelenu priedu gavimo büdas. Lietuvos patentas Nr. 6689. Lietuvos Respublikos valstybinis patentų biuras. 


\section{Summary in English}

\section{Introduction}

\section{Formulation of the problem}

Since the amount of municipal waste is constantly increasing as the economy grows, incineration of such waste is now considered to be the most advanced municipal waste recovery technology with the least impact on the environment. As a result, there is a huge demand in the world for the reuse of fly ash and bottom ash from municipal incineration waste. In the last decade, fly ash and bottom ash from municipal solid waste incineration (MSWI) have been frequently used in the various building materials industries. In order to solve the problem of the use of fly ash and bottom ash in the production of building ceramics, it is necessary to study their composition and properties, to choose technological parameters properly depending on the used raw materials, to evaluate the effect on the properties and structure of clay bricks. However, the usage of these additives has a negative effect on the properties of clay bricks, and the leaching of heavy metals, chlorides, sulphates from clay bricks often exceeds the regulatory limits.

As a result, in the production of ceramic products, the technological parameters of production are usually adjusted: the burning temperature is rising, holding time at maximum burning temperature, what is energy inefficient, expensive, and using easily fusible hydromica clays is sometimes not possible. Therefore, the need for the development of ceramic products using easily fusible hydromica clays and fly or bottom ash at a low burn- 
ing temperature of $1000{ }^{\circ} \mathrm{C}$ is obvious for making a significant contribution to the ecological balance of the country and the region by effectively reducing such waste and saving fossil raw materials.

By using fly ash or bottom ash from MSWI and taking into account the composition and properties of the clay, it is possible to create a clay bricks without significantly compromising the performance of the products and such products would not pose a risk to human health or the environment during usage and at the end of their life cycle.

\section{Relevance of the thesis}

MSWI are recognized as a renewable energy source under the Renewable Energy Directive 2009/28/EC. Incineration of waste with heat and/or electricity is considered as a proper waste management in Europe. There are around 500 cogeneration plants which are burning mixed municipal waste across the Europe. There are currently 3 municipal waste incineration plants operating in Lithuania (Vilnius Cogeneration Power Plant, Kaunas Cogeneration Power Plant and UAB "Fortum Klaipeda"), where municipal waste up to 550000 tons/year can be incinerated. Incineration of 1 ton of municipal waste generates on average about $20-25 \%$ of slag (bottom ash) and about 2-5\% of fly ash. Incineration of municipal waste generates significant amounts of bottom and fly ash. Around 10 000-15 $000 \mathrm{t}$ of fly ash and about 100 000-130000 tons of bottom ash can be generated in cogeneration power plants operating in Lithuania per year. (VCPP, 2017; LR Statistics Department, 2020). Landfilling of fly ash and bottom ash is expensive and has a negative impact on the country's ecological balance, therefore the need for reuse/recovery of such waste is obvious.

At present, fly ash and bottom ash from municipal incineration waste are practically not utilized in Lithuania, although the usage of such waste would reduce environmental pollution and help to save and conserve natural resources. Therefore, this work addresses the potential to use fly ash which are received from cogeneration plants and contain high levels of heavy metals, chlorides, sulphates and are classified as hazardous waste according to the European Waste Catalog, as well as bottom ash for the production of building ceramics using hydromica clay. Building ceramic products are developed and researched, the effect of fly ash or bottom ash on the structure and properties of clay bricks is examined, and environmental aspects of its usage were assessed (toxicity).

\section{Object of research}

The object of the research is building ceramics with fly ash and bottom ash generated in cogeneration power plants after municipal waste incineration.

\section{Aim of the thesis}

To investigate the structure and properties of clay body made using easily fusible hydromica clay and fly and bottom ash generated in municipal waste solid incinerator.

\section{Objectives of the thesis}

In the order to achieve the aim of the thesis, it is necessary to solve the following objectives: 
1. To study the composition and structure of fly ash and bottom ash generated in municipal waste incineration plants, to evaluate their toxicity to the environment.

2. To evaluate the effect of fly ash and bottom ash on the mineral composition of clay bricks and to determine the peculiarities of structure formation.

3. To determine the effect of fly ash and bottom ash on the physical-mechanical characteristics, structural parameters and durability of fired clay bricks.

4. To provide recommendations on the usage of fly ash and bottom ash in the production of building ceramics.

\section{Research methodology}

Analytical and experimental research methods are applied in the work. The main properties of building ceramics were determined on the basis of standard test methods for such products (LST EN 771, LST EN 772) and non-standardized test methods. Scanning electron microscopy, X-ray and thermographic analysis methods were used to evaluate the structure. Mathematical and statistical methods were used to process the experimental data and to evaluate their reliability.

\section{Scientific novelty of the thesis}

Peculiarities of clay bricks structure formation were determined using fly ash and bottom ash from cogeneration plants after municipal waste incineration, when the formation of pores and changes in mineral composition are determined by the structure and composition of fly and bottom ash particles, and physical-chemical processes taking place in clayfly ash and clay-bottom ash systems. This makes it possible to stabilize the ions of heavy metals, chlorides and sulphates in building ceramic products when easily fusible hydromica clay is used.

\section{Practical value of the research findings}

The results of the research can be used in the production of building ceramics, solving the environmental issues of the reuse of fly and bottom ash generated after the incineration of municipal waste. The use of such waste additives in the production of building ceramics helps to utilize hazardous fly ash and bottom ash, save natural raw materials and to create building ceramic products, which even at the "end of the life cycle" would be classified as inert waste, considering the leaching values of heavy metals, chlorides and sulphates. Based on the performed research, recommendations have been provided due to usage of fly ash and bottom ash generated after municipal waste incineration for the production of building ceramics.

\section{Defended statements}

1. Fly ash and water treated fly ash determine the formation of a calcium sulphate mineral in the clay body, change the structure of the clay body by forming additional pores, which increase the total porosity by $3.7-8 \%$ and negatively affect its durability, compared to clay body without fly ash.

2. Bottom ash containing at least $45 \%$ of $\mathrm{SiO}_{2}$ can be used as a non-plastic additive in easily fusible hydromica clay, which decrease the shrinkage by $2.2-3.0 \%$. The 
addition of 5\% bottom ash allows to obtain analogical values of compressive strength and $8 \%$ lower density of clay body, compared to clay body without bottom ash.

\section{Approval of the research findings}

7 articles were published on the topic of the dissertation: two articles in scientific journals listed in the Clarivate Analytic Web of Science database with a citation index, two articles in Conference Proceedings publications of the Clarivate Analytics Web of Science database, three articles in publications of other international databases. Based on the research results, a Lithuanian patent was prepared.

The results of the research conducted in the dissertation were published in seven scientific conferences in Lithuania and other countries:

- International conference "MBMST 2019: the 13th international conference on modern building materials, structures and techniques" in 2019, Vilnius;

- International Conference (International Symposium) "WMCAUS 2019: the 4th world multidisciplinary civil engineering-architecture-urban planning symposium" 2019, Prague, Czech Republic;

- International conference "IMST 2019: the 4th international conference on innovative materials, structures and technologies" in 2019, Riga, Latvia;

- In the International Forum "Cooperation is a catalyst for innovative growth: 3, 5 Belarusian-Baltic Forum” 2017, 2019 m. Minsk, Belarus;

- International Conference "MALTOVINY 2018" in 2018, Brno, Czech Republic;

- International Conference "Architectural and construction complex: problems, prospects, innovations: an international scientific conference dedicated to the 50th anniversary of Polotsk State University " 2018. In Novopolock, Belarus;

- At the 21st Lithuanian Young Scientists Conference "Science - the Future of Lithuania" on March 14 and 20, 2018, in Vilnius.

\section{Structure of the thesis}

The dissertation is comprised of an introduction, three chapters, general conclusions, recommendations, lists of references, sources, and autor's publications on the subject of the dissertation, summary in English and two annexes.

The volume of the dissertation is 130 pages, excluding annexes, 2 numbered formulas, 57 figures and 20 tables are used in the text. 146 literature sources were used in writing the dissertation.

\section{Literature review on the usage of fly ash and bottom ash from municipal solid waste incineration in the production of building ceramics}

The municipal waste treatment process for energy production involves the thermal treatment of waste, where municipal waste is incinerated at a temperature of approximately $1000{ }^{\circ} \mathrm{C}$. During heat treatment, the mass and volume of municipal waste decrease by 65 $80 \%$ (Bertolini et al., 2004). Municipal waste incineration produces mainly bottom ash about $95-97 \%$, the rest of it (from 3\% to 5\%) is fly ash (Van Herck et al., 2000; Wunsch 
et al., 1996). The European Waste Catalog classifies fly ash as hazardous waste (code 1901 13), but slag and ash are classified as non-hazardous waste (code 1901 12) (European Waste Catalogue (EWC), 2015). The literature (Taurino et al., 2017a; Shih et al., 2003; Giro-Paloma et al., 2017; Lin, 2006; Colangelo et al., 2015; Tang et al., 2015; Lin et al., 2006) indicates that the main ash components of the waste bottom are $\mathrm{SiO}_{2}, \mathrm{CaO}$, $\mathrm{Al}_{2} \mathrm{O}_{3}, \mathrm{Fe}_{2} \mathrm{O}_{3}$, etc., small amounts of heavy metals are also found as well. According to the mineral composition, quartz $\left(\mathrm{SiO}_{2}\right)$ and calcite $\left(\mathrm{CaCO}_{3}\right)$ are most commonly found minerals in the bottom ash, and may also contain gelenite $\left(\mathrm{Ca}_{2} \mathrm{Al}(\mathrm{SiAl}) \mathrm{O}_{7}\right)$ and hematite $\left(\mathrm{Fe}_{2} \mathrm{O}_{3}\right)$ minerals (Yanga et al., 2018; Cheeseman et al., 2005; Vegas et al., 2008; Wongsta et al., 2017). These minerals are often formed in the production of fired clay bricks, so bottom ash is considered to be a suitable additive for their production. The use of fly ash from municipal incineration waste in building ceramics is particularly relevant for the binding or immobilization of heavy metals, which are abundant in fly ash, into insoluble compounds at high temperatures. At high temperature, $\mathrm{Pb}$ and $\mathrm{Zn}$ metals seem to be "encapsulated" in clay bricks, what significantly reduces their leaching values (Arsenovic et al., 2012, 2015). The authors (Haiying et al., 2011; Yang et al., 2009; Lin et al., 2006) state that the leaching of the main heavy metals $(\mathrm{Cd}, \mathrm{Pb}, \mathrm{Zn}, \mathrm{Hg})$ from the fly ash of municipal incineration waste is significantly reduced since they are blocked in the liquid phase at high temperatures. Before usage in the production of building ceramics, fly ash can be additionally treated with water, thus reducing the content of $\mathrm{Pb}, \mathrm{Zn}, \mathrm{Cu}$ elements (Wang et al., 2016), as well as the content of chlorides (Wu et al., 2015), which can adversely affect the quality of ceramic products.

\section{Materials and research methods}

For the experimental tests, hydromica with kaolinite additive of Kuksa reservoir clay (Lithuania) and a non-plastic additive were used. Municipal waste incineration waste, fly ash and bottom ash were taken from the cogeneration power plant UAB Fortum Klaipeda. The chemical composition of the clay used for the research is characterized by a high content of $\mathrm{Al}_{2} \mathrm{O}_{3}+\mathrm{TiO}_{2}(20.54 \%)$ and $\mathrm{Fe}_{2} \mathrm{O}_{3} \quad(7.44 \%)$, a small amount of $\mathrm{CaO}+\mathrm{MgO}(4.26+3.07 \%)$, the amount of organic impurities, which reach $9.54 \%$ (Table 2.1). Mineralogical research of clay (Fig. 2.2) revealed that the following minerals predominate in clay: hydromica, quartz, feldspar, kaolinite. X-ray examinations of clay fired at $1000{ }^{\circ} \mathrm{C}$ (Fig. 2.3) showed that the main minerals are: anorthite, quartz, hematite, spinel, diopside. The clay and bottom ash examined in the work were crushed with a gill crusher and dried for 24 hours at $60 \pm 5^{\circ} \mathrm{C}$, for 24 hours at a temperature of $100 \pm 5^{\circ} \mathrm{C}$, then passed through a $1.25 \mathrm{~mm}$ sieve. The sand was dried and sieved through a $1.25 \mathrm{~mm}$ sieve. All the formed formation masses were prepared in the same way by changing the amount of municipal incineration waste - fly ash (LP), water-treated fly ash (VLP) and bottom ash (DP) in the formation masses. The amount of water required for the formation ranged from $22 \%$ to $25 \%$. The compositions of the forming masses considered in the work are presented in Table S.2.1. $70 \times 70 \times 70 \mathrm{~mm}, 50 \times 50 \times 50 \mathrm{~mm}$ and $60 \times 30 \times 18 \mathrm{~mm}$ samples were formed from the given formation masses compositions. The initial drying step of the formed samples was performed under natural laboratory conditions for 2 weeks (at a temperature of $18 \pm 5^{\circ} \mathrm{C}$ ). Then the samples were dried according to the selected mode: on the first day at $60 \pm 5^{\circ} \mathrm{C}$, on the second day at $105 \pm 5^{\circ} \mathrm{C}$. Burning of the samples was 
performed at $1000{ }^{\circ} \mathrm{C}$, maintaining the highest burning temperature for $1 \mathrm{~h}$. Composition analysis of the materials was performed with a DRON-7 and SmatLab X-ray diffractometer. The chemical composition of the materials was determined using the X-ray fluorescence (XRF-WD) method with a ZSX Primus IV spectrometer. DTA of the materials was performed with a Linseis STA PT-1600 instrument. The SEM JEOL JSM - 7600 F scanning electron microscopy instrument was used to study the microstructure of the materials.

The compressive strength of the clay bricks was determined according to LST EN 772-1:2011 + A1:2015, the bulk density was determined according to LST EN 772-13:2003, the water absorption was determined according to EN 77221:2011, the initial water absorption rate according to LST EN 772-11:2011. The durability of the samples was evaluated by all-side and one-side freeze-thaw methods, according to LST 1985:2006 and LST EN 772-22:2019. Drying and burning shrinkages were determined in accordance with ASTM C326-09 (2014). The technological parameters of the forming masses were determined in accordance with ASTM D 4318:2005.

Table S2.1. Compositions of the formation masses wt.\% (by weight)

\begin{tabular}{|l|l|l|l|l|}
\hline \multirow{2}{*}{ Compositions } & \multicolumn{2}{|l|}{ Raw materials } & Sand & $\begin{array}{l}\text { Fly ash and water- } \\
\text { treated fly ash }\end{array}$ \\
\cline { 2 - 5 } & Clay & Bottom ash & \\
\hline C & 100 & 0 & 0 & 0 \\
\hline CS & 90 & 10 & 0 & 0 \\
\hline FA 2.5 & 87.5 & 10 & 2.5 & 0 \\
\hline FA 5 & 85 & 10 & 5.0 & 0 \\
\hline FA 7.5 & 82.5 & 10 & 7.5 & 0 \\
\hline FAW 2.5 & 87.5 & 10 & $2.5^{*}$ & 0 \\
\hline FAW 5.0 & 85 & 10 & $5.0^{*}$ & 0 \\
\hline FAW 7.5 & 82.5 & 10 & $7.5^{*}$ & 0 \\
\hline BA 5 & 95 & 0 & 0 & 5.0 \\
\hline BA 10 & 90 & 0 & 0 & 10.0 \\
\hline BA 15 & 85 & 0 & 0 & 15.0 \\
\hline
\end{tabular}

The content of heavy metals in the eluates (from clay bricks) was determined by atomic adsorption spectral analysis using a Buck Scientific 2010 VGP spectrometer with an air-acetylene flame. The eluate was prepared according to LST EN 12457-2:2003. Dry matter of bottom and fly ash was determined according to DIN 38414-2:1985-11, dissolved organic carbon content according to EN 1484:2019-04, total organic carbon content according to ISO 10694:1995, chloride, sulphate, fluoride, sulphur content according to EN ISO 10304-1: 2009. The content of heavy metals in the eluates (from bottom and fly ash) was determined according to EN ISO 11885:2009-09 (E22). Radiation measurements were performed with a gamma spectrometer with a coaxial pure germanium detector to evaluate the radioactivity concentration of clay bricks according to the standard IEC 142:1995 IEC. 


\section{Research of municipal solid waste incineration fly ash, bottom ash and of structure, properties and durability of clay bricks}

It was found that fly ash contained a high content of $\mathrm{CaO}$, which was $45.17 \%$, chlorides (mainly $\mathrm{KCl}, \mathrm{NaCl}, \mathrm{MgCl}_{2}$ ) - 19.01\%, sulphate - 0.82-1.56-7.32\%, $\mathrm{Na}_{2} \mathrm{O}, \mathrm{K}_{2} \mathrm{O}, \mathrm{MgO}$, $\mathrm{Al}_{2} \mathrm{O}_{3}, \mathrm{Fe}_{2} \mathrm{O}_{3}, \mathrm{TiO}_{2}$, and heavy metals: lead, cadmium, chromium, copper, mercury, molybdenum, tin, wolfram, strontium, etc. (Table 3.1). MSWI fly ash was found to have a specific electrical conductivity of $15.26 \mathrm{mS} / \mathrm{cm}$ and a $\mathrm{pH}$ of 11.93 . The specific electrical conductivity of water-treated fly ash decreases to $11.89 \mathrm{mS} / \mathrm{cm}$ and the $\mathrm{pH}=11.65$. Signs of fly ash decrease in specific electrical conductivity indicate a decrease in charged particles. X-ray analysis of fly ash (Fig. 3.4) showed that the following minerals predominate in the ash: calcite, calcium chloride, potassium calcium chloride, potassium chloride, sodium chloride, and anhydrite. Water-treated fly ash (Fig. 3.5) is dominated by minerals of calcite, calcium chloride, potassium calcium chloride, sodium chloride, potassium chloride and aluminum chloride. The bottom ash was found to consist of: $47.6 \% \mathrm{SiO}_{2}, 8.4 \%$ $\mathrm{Al}_{2} \mathrm{O}_{3}, 9.7 \% \mathrm{Fe}_{2} \mathrm{O}_{3}, 20.8 \% \mathrm{CaO}, 2.7 \% \mathrm{MgO}, 2.9 \% \mathrm{SO}_{3}, 1.3 \% \mathrm{~K}_{2} \mathrm{O}, 3.0 \% \mathrm{Na}_{2} \mathrm{O}, 0.4 \% \mathrm{Cl}$, L.o.i - 3.2\% (see Table 3.3). An X-ray of the bottom ash (Fig. 3.10) showed that it is dominated by quartz and calcite minerals.

Minerals of quartz, hematite, albite-anorthite, spinel, diopside are identified in the CS (control clay brick) clay brick. Isomorphic minerals, plagioclases - albite-anorthite, hematite, spinel, diopside, as well as calcium sulphate were identified in clay bricks with LP and VLP. Analysis of X-ray examinations of clay samples with LP revealed a slight difference in the intensities of the detected diopside, anorthites and spinel minerals. It was found that with the introduction of $2.5 \% \mathrm{LP}$, the minerals intensity of diopside and spinel identified in the clay brick was lower than that of the clay brick with 5\% LP. It should be emphasized that the quantitative analysis of the intensity of the peaks is rather limited, but it is stated in the literature (Mao et al., 2016; Tang et al., 2010, 2014; Lu \& Shih, 2012, 2015) that the formation of minerals may be affected by the presence of heavy metals in the fly ash. Heavy metals such as $\mathrm{Cu}, \mathrm{Zn}, \mathrm{Ni}$, etc. can interfere with the structure of the spinel or/and diopside and thus affect their identification and intensity. It should also be noted that calcium sulphate mineral is identified in clay bricks with LP and VLP. The formation of this mineral is influenced by a sufficiently high content of calcium and sulphates in fly ash. Calcium sulphate mineral is not a preferred mineral in the building ceramics industry, as it can negatively affect the structure of clay bricks by increasing porosity due to its properties - sufficiently large volume and the possibility of formation in pores. Further conducted research confirms this.

The area of endothermic curves of FA 2.5 clay brick at $720-733{ }^{\circ} \mathrm{C}$ is significantly smaller compared to CS clay brick, which indicates a higher degree of decarbonization of fired clay bricks and influences the lower formation of new crystalline phases in the clay bricks (Fig. S3.1.). The bonds in the crystalline structure of clay minerals, which are associated with the formation of new compounds such as anorthite-albite, are weakened. A significant decrease in temperature and reaction area is also associated with the decomposition of sulphate found in fly ash. The authors (Eliche-Quesada et al., 2017) believe that the decomposition of sulphates affects not only changes in temperature, but also changes 
in weight loss occur. As can be seen from the presented figures, the weight loss increases to $11 \%$ compared to the control clay brick when introducing $2.5 \%$ of LP content into the forming masses. The fact that the thermodynamically stable phase - anorthite in the clay sample is significantly reduced is confirmed by the further mechanical research of the clay bricks. Besides, the results found and mentioned in the literature (Mao et al., 2016; Tang et al., 2010, 2014; Lu \& Shih, 2012, 2015) show that the amount of such additives and their contamination with heavy metals make negative impact on the formation of new thermodynamically stable minerals. During the exothermic processes recorded at a temperature of about $900{ }^{\circ} \mathrm{C}$, small differences in the degree of crystallization of all examined minerals of the clay bricks are observed. The authors (Chen et al., 2012) state that at temperatures above $950{ }^{\circ} \mathrm{C}$, potassium and sodium chlorides, which are found in the composition of LP, evaporate. The above-mentioned observation also contributes to a slightly higher weight loss of clay bricks with LP and VLP (Fig. S3.1. b).

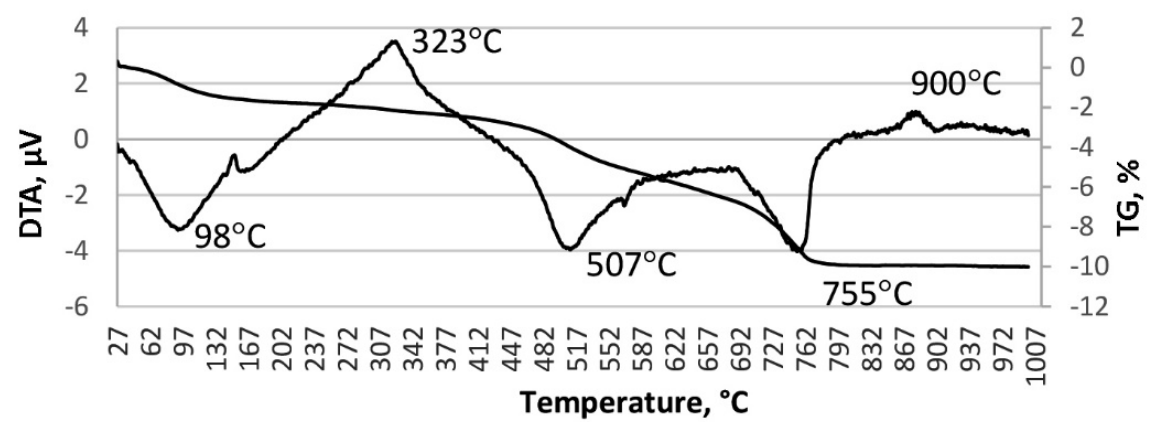

a)

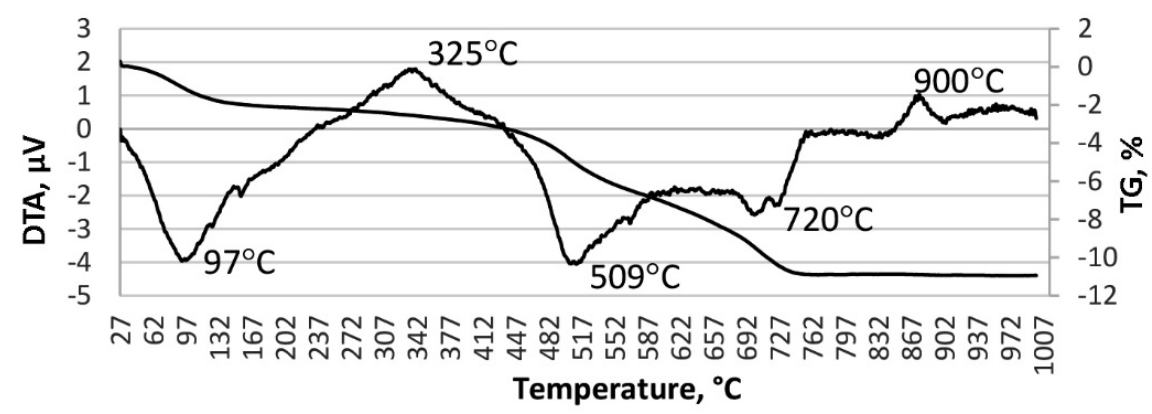

b)

Fig. S3.1. Thermograms of clay bricks: a) CS, b) FA 2.5

It was found that the amounts of heavy metals, chlorides and sulphates leached from clay bricks FA 2.5, FAW 2.5-7.5\% do not exceed the limit values for inert waste according to $2003 / 33 / \mathrm{EC}$. It has also been found that the content of radionuclides in different 
clay products can vary. The activity index values determined for all tested samples are lower than the level of radionuclide concentration which is allowed by the European Union and Lithuanian norms (HN 85: 2011, No. V-890). After evaluating the impact of municipal combustion waste LP and VLP on the mineralogical composition of clay bricks, aesthetic product quality and taking into account leaching studies of heavy metals from clay bricks, ensuring safe use of fly ash in building ceramic products, clay bricks FA 2.5; FAW 2.5; FAW 5.0; FAW 7.5 were further investigated.

The open porosity of the control clay brick without the analyzed additive (CS fired clay brick) is $18.0 \%$. The $2.5 \%$ LP clay brick increases the open porosity to $27.7 \%$, and the $2.5 \%$ VLP only to $20.6 \%$. With the introduction of the maximum $7.5 \%$ VLP, the open porosity of the clay brick increases to $25.8 \%$ (Fig. S3.2.). Water absorption studies of the fired samples showed that the $2.5 \%$ LP of clay brick increases the water absorption to $15.3 \%$, while the $2.5 \%$ VLP only to $11.7 \%$. Even with the introduction of a maximum amount of $7.5 \%$ VLP, the water absorption of clay brick is lower than with the introduction of $2.5 \%$ LP and reaches $14.5 \%$.

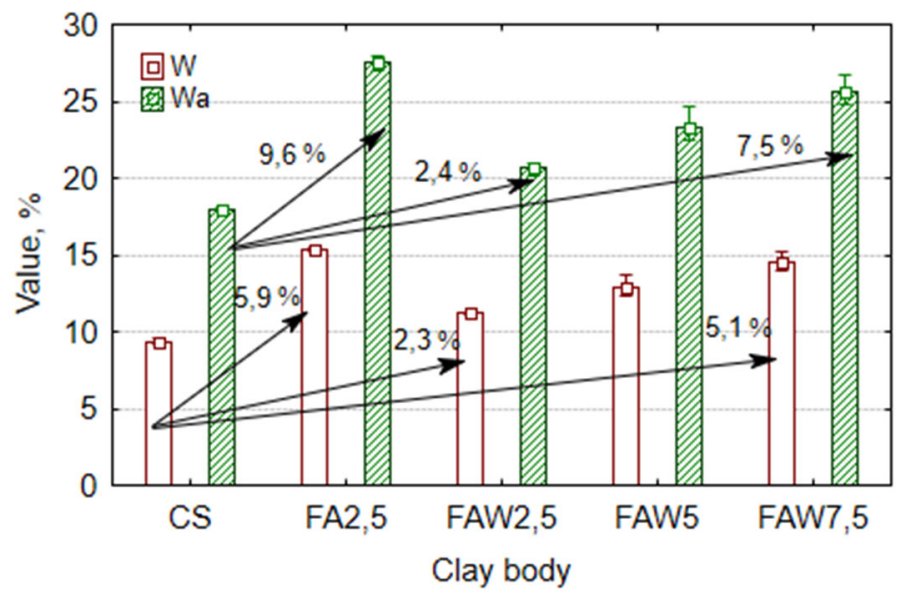

Fig. S3.2. Influence of fly ash and water-treated fly ash on open porosity $\left(W_{a}\right)$ and water absorption $(W)$ of clay brick ( $\rightarrow$ change $(\%)$ compared to CS clay body)

LP and VLP reduce the density of clay bricks and increase the total porosity (Fig. S3.3.). The LP clay bricks reduce the density from $6.25 \%$ to $1.80 \mathrm{~g} / \mathrm{cm}^{3}$ and increase the total porosity to $31.2 \%$ compared to the CS clay brick. The best results were obtained by introducing $2.5 \%$ VLP into the systems. The density of the FAW 2.5 clay brick decreased by $4.1 \%$ and reaches $1.84 \mathrm{~g} / \mathrm{cm}^{3}$, and the total porosity increased to $27.3 \%$. As the amount of VLP in the forming masses further increases, the density decreases and the values of total porosity increase. The increase in the porosity (open and total porosity) values of FA 2.5 and FAW 2.5, FAW 5 and FAW 7.5 is influenced by additional random porous cavities formed in the structure, which formation is determined by the structure 
and composition of fly ash particles, mainly calcium sulphate compounds. The compressive strength of the CS clay brick reaches $35 \mathrm{MPa}$. LP and VLP reduce the compressive strength of fired samples. The $2.5 \%$ LP clay brick reduces the compressive strength to $27 \mathrm{MPa}$ and the $2.5 \% \mathrm{VLP}$ to $30 \mathrm{MPa}$. The maximum amount of $7.5 \%$ VLP reduces the compressive strength of the clay brick to $24 \mathrm{MPa}$.

Microstructure analysis of clay samples are presented in Fig. S3.4. As can be seen; the structure of the CS fired clay brick is sufficiently dense, with a small number of pores predominating. The pores have an oval shape, they are evenly distributed throughout the clay brick and are larger than 1.5-2 $\mu \mathrm{m}$. No defects or cracks were observed in the microstructure of the fired samples, which means that the technological combustion parameters were chosen correctly, the amount of liquid phase formed during combustion was sufficient to fill the entire clay brick matrix evenly.

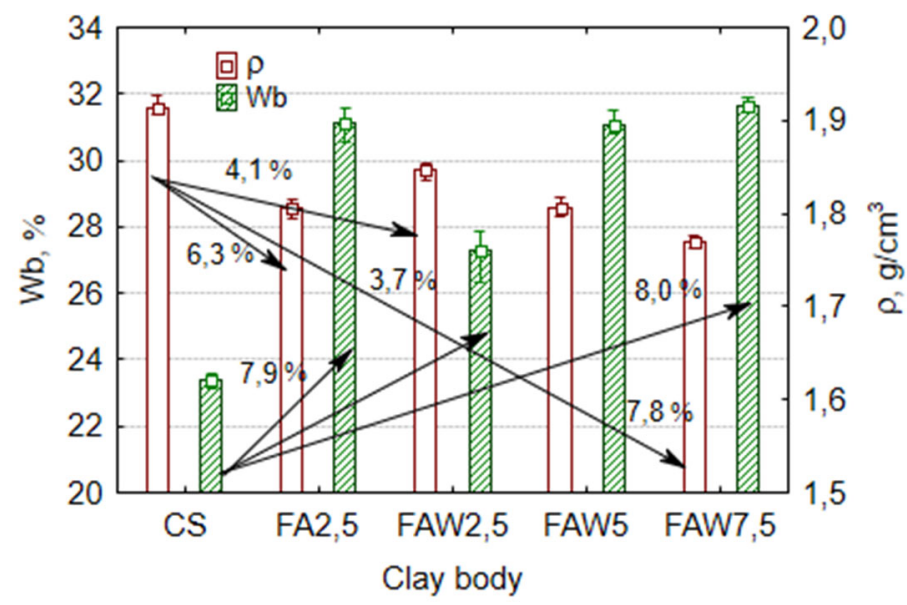

Fig. S3.3. Influence of fly ash and water-treated fly ash on clay brick density $(\rho)$ and total porosity $\left(W_{b}\right)(\rightarrow$ change $(\%)$ compared to CS clay body)

The microstructure of the sample's changes when LP, VLP are introduced into the forming masses and fired at $1000^{\circ} \mathrm{C}$. The microstructure of FA 2.5 clay brick is dominated by elongated pores less than $1 \mu \mathrm{m}$, which are distributed throughout the matrix. The edges of the pores are very uneven. Very fine $\leq 0.5 \mu \mathrm{m}$ pores are also observed. The FAW 2.5 sample structure clearly has fewer pores than the FA 2.5 structure and liquid phase content is higher. The pores are small, more round, larger than $1 \mu \mathrm{m}$, and the matrix surface is denser. The microstructure of FAW 7.5 shows that the matrix becomes less dense, dominated by large irregularly shaped pores which are open and progress to elongated (1.0 $2.0 \mu \mathrm{m}$ ) pores. It is known (Sveda, 2001; Koroth et al., 1998; Cimmers et al., 2005) that $1.0-1.5 \mu \mathrm{m}$ pores negatively affect the durability of building ceramics. The high content of various sulphates, chlorides, and $\mathrm{CaO}$ in the additives affected the microstructure of the clay bricks by introducing higher levels of LP or VLP. The structure of the clay brick 
(forming of sulphates, evaporating of chlorides, decomposing of $\mathrm{CaCO}_{3} \sim 750^{\circ} \mathrm{C}$ ) becomes more porous. This is confirmed by the scientific work performed by the authors (Cao et al., 2017, Eliche-Quesada et al., 2017, Chen et al., 2012).

The performed microstructural EDS studies confirmed the mineralogical studies of clay bricks with LP and VLP and showed that $\mathrm{CaSO}_{4}$ minerals are found in the structure. Calcium sulphate minerals are most commonly identified in the pores, and there is not a good contact zone between matrix and them, so the appearance of these minerals affects the increase in porosity of the samples. Also, the $\mathrm{CaSO}_{4}$ mineral has a sufficiently large volume which has a destructive effect on the pore walls of the clay brick (it is usually formed by filling the pores) and it affects the porosity and strength properties of the fired sample. The obtained microstructural studies correlate with the results of physical-mechanical properties and porosity indicators obtained by these clay bricks. After evaluating the obtained research results, it was found that with the introduction of LP or the increase of VLP content, the durability of clay bricks, in terms of frost resistance, decreases. As the amount of LP and VLP in a clay brick increases, so does the amount of calcium compounds in it. The appearance of such compounds, as it was mentioned earlier, increases the porosity of the products and the impregnation of water. Increasing porosity and water absorption have a negative impact on the frost resistance of fired samples which were determined by both one-side and all-side freeze-thaw methods.

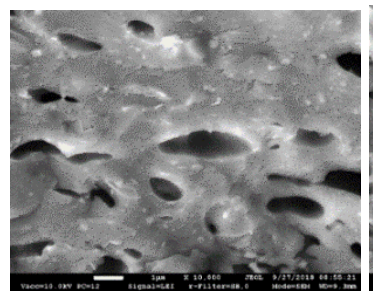

a)

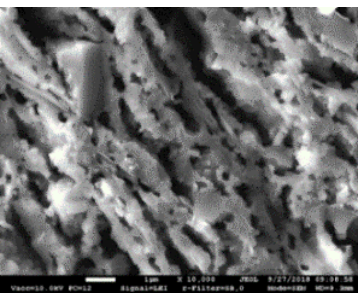

b)

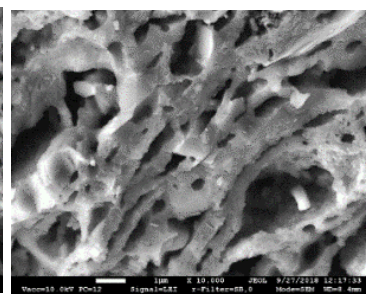

c)

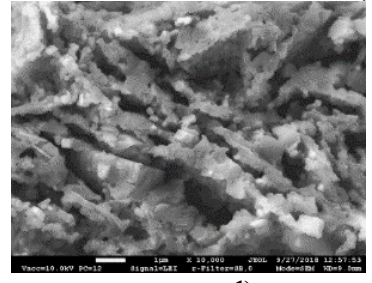

d)

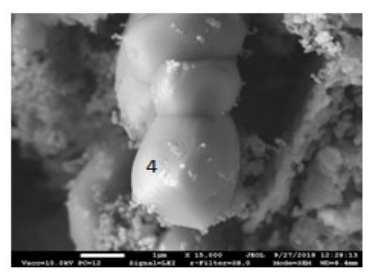

e)

Fig. S3.4. The microstructure of clay brick: a) CS; b) FA 2.5; c) FAW 2.5; d) FAW 7.5; e) identified (4) $\mathrm{CaSO}_{4}$ mineral

Investigations of clay bricks mineral composition of C, BA 5, BA 10, BA 15 showed that anorthite, quartz, spinel, hematite, diopside minerals were identified in all samples. The aforementioned minerals is standard minerals formed during the combustion of natural aluminosilicate raw materials. Comparing the thermographic studies of $\mathrm{C}$ clay brick and clay bricks with bottom ash, no significant differences were observed. However, it has been found that DP affects the decomposition of magnesium and calcium carbonates 
in clay (temperature $748-764{ }^{\circ} \mathrm{C}$ ), it occurs at higher temperatures, and reaction area under the peaks decreases. This influences the formation of the clay bricks crystalline grid at higher temperatures, and negatively affects the formation of new thermodynamically stable phases (e.g., anorthite). Studies of heavy metals' leaching from clay bricks with DP have shown that with the increase of the amount of DP in the clay brick, the concentrations of leaching heavy metals, chlorides and sulphates from the examined clay bricks increase. For example, when $15 \%$ of DP was introduced into clay brick and fired at $1000{ }^{\circ} \mathrm{C}$, the concentration of leaching $\mathrm{Zn}$ from the clay brick increased 2.3-fold compared to the control clay brick, even 160-fold increase of $\mathrm{Cu}, 10$-fold of $\mathrm{Pb}$, and 2.6-fold of $\mathrm{Cr}$ leaching concentrations. There was also a 2 -fold increase in leaching concentrations of sulphates and 3.3-fold increase in chlorides. However, it is worthy to note that the leaching values of $\mathrm{Cu}, \mathrm{Cd}, \mathrm{Cr}, \mathrm{Pb}, \mathrm{Zn}, \mathrm{Ni}$, chlorides and sulphates do not exceed the leaching limit values of inert waste in the applicable normative documents according to the requirement of $2003 / 33 /$ EC. The performed microstructural studies of the examined samples showed (Fig. S3.5.), that by introducing 5\% of DP into the forming mass and firing it, the morphology of the samples almost does not change compared to the $\mathrm{C}$ samples.

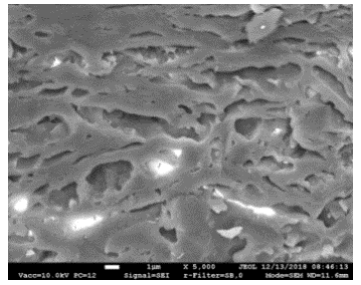

a)
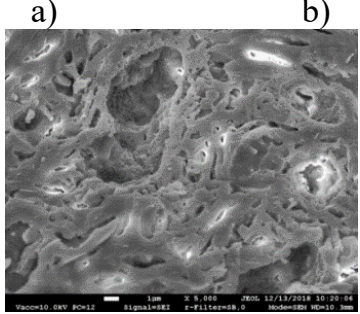

d)

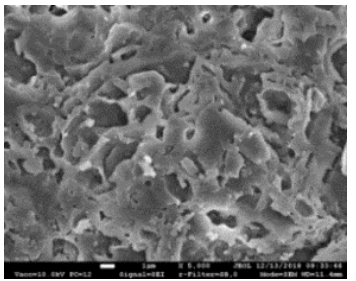

b)

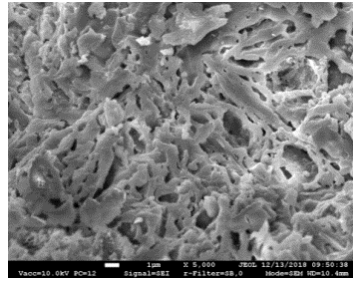

c)

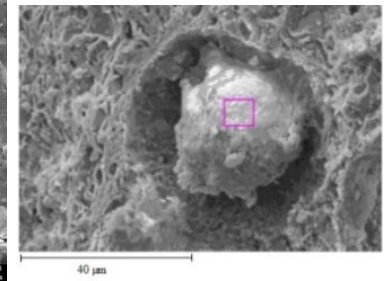

e)

Fig. S3.5. Clay bricks with bottom ash: a) C; b) BA 5; c) BA 10; d) BA 15; e) BA 15 EDS place of research

A sufficiently dense matrix with a small number of pores is visible, the amount of liquid phase is sufficient and evenly distributed over the entire surface, no defect sites are observed. There are elongated and round pores ranging in size from $1 \mu \mathrm{m}$ to $3 \mu \mathrm{m}$. A slight change in structure occurs with the introduction of $10 \%$ of DP. The structure is dominated by a slightly larger number of pores, surface roughness occurs, and a smaller amount of liquid phase is visible. A more pronounced difference is observed with the introduction of $15 \% \mathrm{DP}$, large, round pores appear, the amount of liquid phase is not sufficient to fill large 
2-8 $\mu \mathrm{m}$ round pores (Fig. 3.5. d). The formation of larger pores and random porous cavities in the structure (Fig. 3.5. d, e) is determined by the organic residues and calcium compounds in DP. It has also been found that in some places there may be a weaker bond between the clay matrix and the DP particle in the contact zone. EDS studies of DP particles showed that the particle consists of: $\mathrm{O}-45.78 \%, \mathrm{Si}-21.45 \%, \mathrm{Ca}-15.35 \%, \mathrm{Al}-$ $5.94 \%, \mathrm{Fe}-4.74 \%, \mathrm{Mg}-6,16 \%, \mathrm{Ti}-0.58 \%$. Sufficient amount of calcium in the particle suggests that it is a DP particle.

It was found that DP reduce the shrinkage of clay bricks after drying and firing (Fig. S3.6.). The shrinkage of clay brick $\mathrm{C}$ after drying is $9.8 \%$, after firing at $1000{ }^{\circ} \mathrm{C}$, maintaining the highest firing temperature for $1 \mathrm{~h}-12.7 \%$. When $5.0 \%$ of DP is added to the forming mass, the shrinkage after drying is reduced to $8.3 \%$. By increasing the amount of DP in the forming masses from $5.0 \%$ to $15 \%$, the shrinkage after drying decreases to $8.0 \%$ and $7.7 \%$, respectively. The minimum shrinkage after firing was determined by introducing $10-15 \%$ of DP into the forming masses, which reached around $10 \%$.

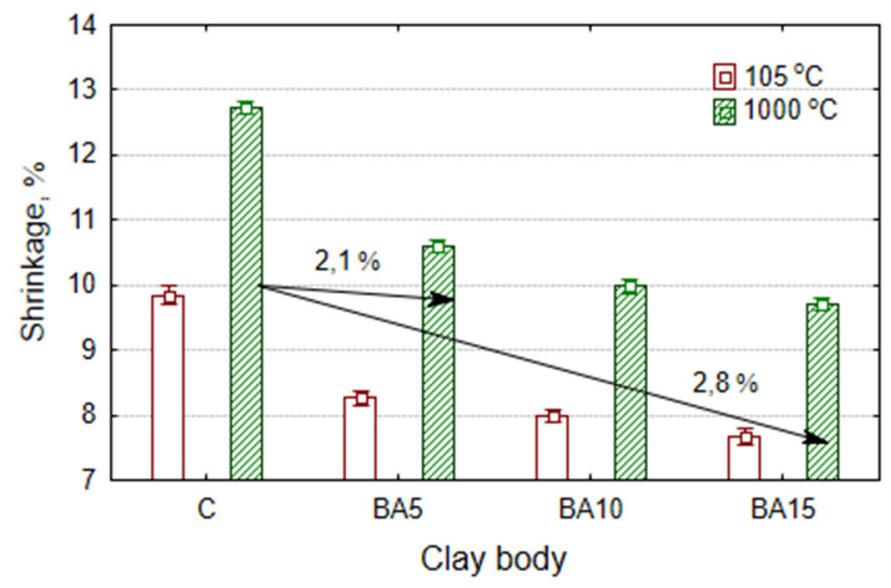

Fig. S3.6. Bottom ash influence on clay brick shrinkage ( $\rightarrow$ change $(\%)$ compared to $\mathrm{C}$ clay body)

It was found that was found that $5 \%$ of DP slightly reduce the density of the clay bricks by $8 \%$, but the compressive strength of this clay brick remains high, very close to the determined result of the control clay brick and reaches $44 \mathrm{MPa}$ (Fig. S3.7.). With the introduction of a higher amount of DP, the bulk density and compressive strength of clay bricks decrease. Clay bricks with a content of $10 \%$ DP have a density of $1.77 \mathrm{~g} / \mathrm{cm}^{3}$ and a compressive strength of $35 \mathrm{MPa}$. It should be noted that by introducing $10 \%$ sand into the forming mass and firing it at $1000{ }^{\circ} \mathrm{C}$, the resulting clay brick has a bulk density of $1.92 \mathrm{~g} / \mathrm{cm}^{3}$ and a compressive strength of $35 \mathrm{MPa}$. Studies have shown that DP, which contain a large amount of $\mathrm{SiO}_{2}$, act on a clay brick as a non-plastic additive and can therefore be used instead of sand during the production ceramic products. 
Studies have shown that DP increases water absorption and open porosity of clay bricks (Fig. S3.8.). These two properties strongly correlate with the peculiarities of the formed structure of clay body. The minimum amount of 5\% DP increases the water absorption of clay bricks by $4 \%$ and the open porosity by $7 \%$ compared to $\mathrm{C}$ clay brick.

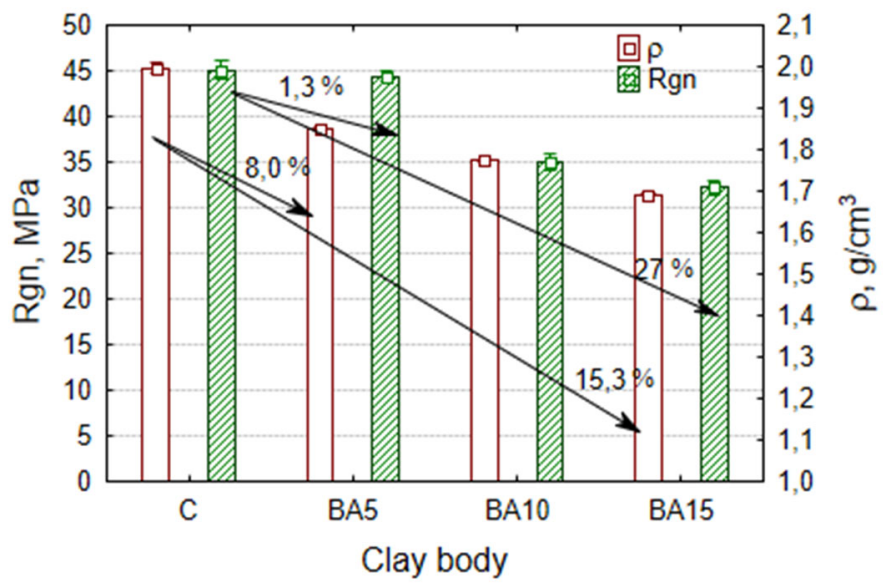

Fig. S3.7. Effect of bottom ash on clay brick density $(\rho)$ and compressive strength $\left(R_{g n}\right)(\rightarrow$ change $(\%)$ compared to C clay body)

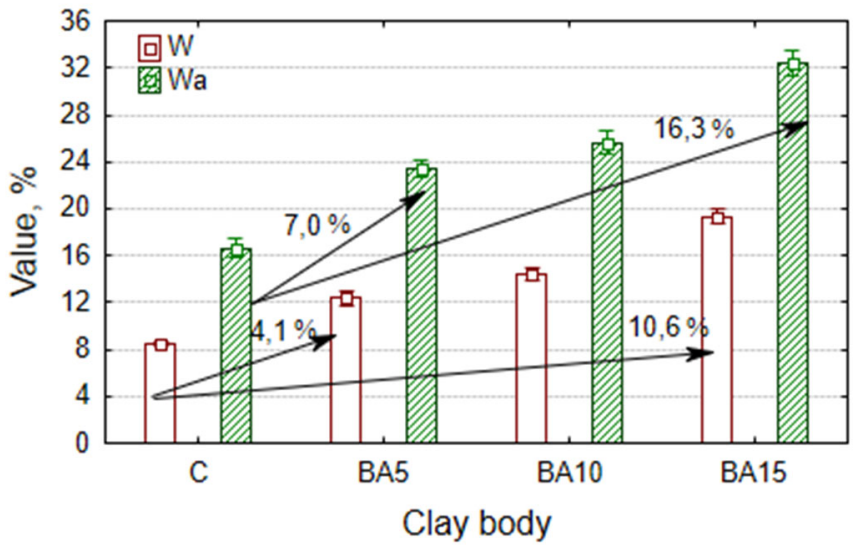

Fig. S3.8. Effect of bottom ash on clay brick open porosity $\left(W_{a}\right)$ and water absorption $(W)$ ( $\rightarrow$ change (\%) compared to C clay body)

The analyzed properties are influenced by the size, shape and mutual distribution of the pores, as well as the amount of liquid phase formed during combustion. The amount of liquid phase, as was mentioned earlier, is not sufficient to fill most of the clay brick 
because the non-plastic DP particles prevented the clay particles from approaching closely to each other, resulting in formed additional pores between the clay matrix and the DP particles in the contact zone. All these phenomena increase water absorption and open porosity, the overall porosity, as well reduce the thickness of the qualified pores and capillary walls. The relative wall thickness of the pores and capillaries decreased by $23 \%$ compared to the control $\mathrm{C}$ clay brick when introducing $5 \%$ of DP into the forming masses and combusting at $1000{ }^{\circ} \mathrm{C}$. The maximum amount of $15 \%$ DP reduces the relative thickness of the pores and capillaries of the clay brick by as much as $51 \%$, and increases the total porosity by $15.4 \%$ (Fig. 3.47).

The obtained results of durability (frost resistance) study of clay bricks with DP show that the amount of $15 \%$ DP significantly reduces the frost resistance of samples. The frost resistance of BA 15 specimens decreases significantly due to the formation of large, connecting pores in the structure that are easily filled with water. Therefore, the water uptake of the sample increases after each cycle. As the relative thickness of the pores and capillary walls of the samples decreases, the overpressure generated during the freezing-thawing process breaks down the pore walls much faster, therefore the destruction processes take place faster in the clay brick. Durability studies have shown that all samples that have been evaluated for frost resistance by a one-side freeze-thaw test in a 100-cycle test have a frost resistance class of F2 (one-side for 100 cycles).

\section{General conclusions}

1. Research results showed that fly ash or water-treated fly ash formed after municipal solid waste incineration affect mineral composition, structure and properties of clay brick, made using easily fusible hydromica clay:

1.1. Calcium sulphate mineral is formed in clay body with $2.5-7.5 \%$ fly ash or watertreated fly ash. 5.0-7.5\% amount of fly ash introduced into the clay body causes diffusion of calcium sulphate mineral into the surface of the sample forming plaque and efflorescence, which impairs the aesthetic quality of the clay body.

1.2. The chemical composition of fly ash or water-treated fly ash influences the formation of a different structure in the clay body. With the formation of calcium sulphate mineral, evaporation of chlorides, decomposition of $\mathrm{CaCO}_{3}$, more long, large and open pores are formed in the structure, which increases the total porosity of the clay body by $3.7-8.0 \%$, decreases the compressive strength by 14 $31 \%$, which negatively affects durability of the clay body.

1.3. Compared to clay body without fly ash, the clay body with $2.5 \%$ fly ash have reduced shrinkage after firing by $1.8 \%$, reduced bulk density by $6.3 \%$ and compressive strength by $22 \%$, increased water absorption by $5.9 \%$ and total porosity by $7.9 \%$; the samples withstand 75 cycles by all-side freeze-thaw method, the samples withstand 100 cycles by a one-side freeze-thaw method.

1.4. Compared to clay body without water-treated fly ash, the clay body with $2.5-$ $7.5 \%$ water-treated fly ash have reduced shrinkage after firing by $1.8-3.2 \%$, bulk density by $4.1-7.8 \%$, compressive strength by $14-31 \%$, increased water absorption by $2.3-5.1 \%$ and total porosity by $3.7-8.0 \%$; the samples withstand 
75-80 cycles by all-side freeze-thaw method, the samples withstand 50-150 cycles by a one-side freeze-thaw method.

2. Based on the research results of clay body with $5.0-15 \%$ bottom ash generated after municipal solid waste incineration it was determined:

2.1. As the amount of bottom ash increases, the structure of the clay bricks changes the pore volume increases, a weaker bond is established between the clay matrix and the bottom ash particle in the contact zone, liquid phase becomes insufficient to fill these pores, which governs formation of larger pores and increase of total porosity by $5.6-15.4 \%$.

2.2. Compared to clay body without bottom ash, the clay body with $5.0-15.0 \%$ bottom ash additive have reduced shrinkage by $2.2-3.0 \%$, bulk density by $7.5-15 \%$, compressive strength by $1.0-27 \%$, increased water absorption by $4.4-10 \%$ and open porosity by $7-16 \%$; the samples withstand $50-100$ cycles by all-side freeze-thaw method, the samples withstand 100-150 cycles by a one-side freeze-thaw method.

3. The studies proved ecologically efficient immobilization of hazardous metals, chlorides and sulphates in clay body. By adding 2.5\% fly ash or 2.5-7.5\% water-treated fly ash or $5.0-15.0 \%$ bottom ash to clay body, $\mathrm{Cu}, \mathrm{Cd}, \mathrm{Cr}, \mathrm{Pb}, \mathrm{Zn}, \mathrm{Ni}$, sulphate and chloride leaching limit values do not exceed leaching limit values for inert waste, according to the regulatory document 2003/33/EC.

\section{Recommendations}

1. Summarizing the obtained results of the study, taking into account the unstable chemical composition of fly ash, in order to fully minimize the leaching potential of hazardous substances (heavy metals, chlorides and sulphates) from fired clay products, it is recommended to utilize up to $2.5 \%$ fly ash or up to $5.0 \%$ water-treated fly ash in the production of fired clay bricks. The obtained clay bricks would have the following characteristics: shrinkage after combustion - up to $9.5 \%$, bulk density is not less than $1.7 \mathrm{~g} / \mathrm{cm}^{3}$, compressive strength is not less than $25 \mathrm{MPa}$, water absorption is not higher than $15 \%$, total porosity is not higher than $31 \%$, frost resistance by all-side freeze-thaw method is 75-80 cycles, 100-115 cycles by one-side freezethaw method; it is worthy to note that such hazardous quantities of fly ash or watertreated fly ash can be safely disposed in building ceramics without endangering nature and human health, even at the end of the product's life cycle.

2. Based on the study results, it has been established that bottom ash in the ceramic products' industry can replace the natural non-plastic sand additive; therefore, it is recommended to use up to $10 \%$ of bottom ash in the production of ceramic products. The obtained clay bricks would have the following characteristics: shrinkage after combustion - up to $10.5 \%$, bulk density is not less than $1.7 \mathrm{~g} / \mathrm{cm}^{3}$, compressive strength is not less than $35 \mathrm{MPa}$, water absorption is not higher than $14.5 \%$, total porosity is not greater than $35 \%$, frost resistance by all-side freeze-thaw method is 90 cycles, 140 cycles by one-side freeze-thaw method. 


\begin{abstract}
A priedas. Autorès sąžiningumo deklaracija
B priedas. Autorès mokslinių publikacijų disertacijos tema kopijos
\end{abstract}

${ }^{3}$ Priedai pateikiami pridètoje kompaktinejje plokštelëje. 
Violeta VOIŠNIENÉ

STATYBINĖS KERAMIKOS SU LAKIAISIAIS IR

DUGNO PELENAIS STRUKTŪROS IR SAVYBIŲ TYRIMAI

Daktaro disertacija

Technologijos mokslai, medžiagų inžinerija (T 008)

INVESTIGATION OF STRUCTURE AND PROPERTIES OF BUILDING CERAMICS WITH FLY AND BOTTOM ASH

Doctoral dissertation

Technological Sciences,

Materials Engineering (T 008)

202109 06. 12,0 sp. I. Tiražas 20 egz.

Leidinio el. versija https://doi.org/10.20334/2021-040-M

Vilniaus Gedimino technikos universitetas,

Saulètekio al. 11, 10223 Vilnius

Spausdino BI UAB „Baltijos kopija“

Kareivių g. 13B, 009109 Vilnius 